Carolina Luísa Alves Barbieri

\title{
Cuidado infantil e (não) vacinação no contexto de famílias de camadas médias em São Paulo/SP
}

\author{
Tese apresentada à Faculdade de Medicina da \\ Universidade de São Paulo para obtenção do título de \\ Doutor em Ciências
}

Programa de Medicina Preventiva

Orientadora: Profa. Dra. Márcia Thereza Couto Falcão

São Paulo

2014 

Carolina Luísa Alves Barbieri

\title{
Cuidado infantil e (não) vacinação no contexto de famílias de camadas médias em São Paulo/SP
}

\author{
Tese apresentada à Faculdade de Medicina da \\ Universidade de São Paulo para obtenção do título de \\ Doutor em Ciências
}

Programa de Medicina Preventiva

Orientadora: Profa. Dra. Márcia Thereza Couto Falcão

São Paulo

2014 


\section{Dados Internacionais de Catalogação na Publicação (CIP)}

Preparada pela Biblioteca da

Faculdade de Medicina da Universidade de São Paulo

$\square$ reprodução autorizada pelo autor

Barbieri, Carolina Luísa Alves

Cuidado infantil e (não) vacinação no contexto de famílias de camadas médias em São Paulo/SP / Carolina Luísa Alves Barbieri. -- São Paulo, 2014.

Tese(doutorado)--Faculdade de Medicina da Universidade de São Paulo.

Programa de Medicina Preventiva.

Orientadora: Márcia Thereza Couto Falcão.

Descritores: 1.Vacinação 2.Saúde da criança 3.Cuidado infantil 4.Família 5.Camada média 6.Gênero e saúde

USP/FM/DBD-235/14 
Às pessoas mais queridas e importantes da minha vida:

Marilena e José Carlos, meus pais.

Marta e Natália, minhas irmãs. Julia, minha sobrinha.

Dona Olívia e Dona Francisca, minhas avós (in memoriam).

Gustavo, meu companheiro. 


\section{Agradecimentos}

Nesses quatro anos, muitas pessoas compartilharam, dividiram, acrescentaram, trocaram, apoiaram essa jornada, me ajudando e ensinando mais do que desenvolver uma teste, a crescer e aprender como ser humano. Esses agradecimentos são uma pequena manifestação da minha gratidão e alegria às parcerias acadêmicas, profissionais e da vida, para aqueles que de alguma forma se dedicaram a mim, e fizeram com que eu me sentisse cuidada.

Primeiramente agradeço à Profa. Dra. Márcia Thereza Couto Falcão, minha querida orientadora, que abraçou minhas inquietações, confiou em mim e em nossa parceria, resultando num feliz encontro. Como ninguém, conseguiu com muita competência, dedicação e alegria a perfeita sintonia entre a arte de me guiar num mundo novo da Saúde Coletiva e da pesquisa qualitativa e a arte de saber quando esse caminho ao desconhecido deveria ser trilhado por mim. Num estilo maternal e bem-humorado único, proporcionou prazerosos momentos de ensinamentos e trocas que foram fundamentais ao meu crescimento como aluna.

Agradeço especialmente ao Prof. Dr. José Ricardo de Carvalho Mesquita Ayres, pela generosidade, pelas importantes contribuições durante as duas qualificações, pelos seus ensinamentos nas aulas e oriundos dos conceitos sobre cuidado, risco e vulnerabilidade, tão inspiradores e fundamentais para o desenvolvimento da minha tese.

Quero agradecer às professoras que também fizeram parte da minha banca de qualificação. À Profa. Dra. Cynthia Andersen Sarti, por fazer-me enxergar o principal norte do meu estudo, que foi fundamental para as escolhas e interligações das temáticas encontradas no empírico e pelas orientações metodológicas, de gênero e família. À Profa. Dra. Eunice Nakamura que, tanto na qualificação quando no seminário sobre cuidado infantil, me fez abrir o horizonte sobre o universo da infância na perspectiva sociológica e sua interface com a saúde, contribuições particularmente muito instigantes e inspiradoras. À Profa. Dra. Maria Amélia de Sousa Mascena Veras, que foi fundamental por expandir meu olhar sobre o Programa Nacional de Imunização e, principalmente, por nortear uma parte difícil, porém extremamente relevante e decisiva 
para o fechamento da minha tese, a discussão da relação individual e coletiva da vacinação.

Agradeço à Profa. Dra. Lilia Blima Schraiber, por seus ensinamentos sobre metodologia qualitativa, pela oportunidade de troca durante a disciplina Medicina e Humanidades e pelos primorosos estudos sobre as práticas de saúde, fundamentais para eu compreender o contexto atual e situar meus achados. Ao Prof. Dr. André Mota, pela oportunidade de aprender tanto durante a disciplina Medicina e Humanidades e em seu curso cativante e instigante.

Ao Prof. Dr. Fernando Mussa Abujamra Aith, que foi substancial para aprimorar minha compreensão acerca das questões legais que envolvem a vacinação no Brasil. À Profa. Dra. Hillegonda Maria Dutilh Novaes, pela importante contribuição sobre a temática do cuidado infantil e a puericultura.

Agradeço ao Prof. Dr. Eduardo Silveira Netto Nunes, que me proporcionou o acesso à área da História Social da Infância, e cujos estudos envolvendo a relação infância e saúde na América Latina contribuíram muito ao meu trabalho.

Meus sinceros agradecimentos:

Às Profas. Dras. Marta Heloísa Lopes e Ana Marli Christovam Sartori, pela generosidade, disposição e atenção, por terem me ensinado muito sobre vacinas e propiciado meu encantamento com essa temática.

Às queridas Profas. Dras. Heloísa Helena de Sousa Marques e Pilar Lecussan Gutierrez, pela acolhida calorosa no Instituto da Criança e pelo fornecimento de importantes subsídios para a reflexão sobre as questões éticas acerca do cuidado e a não vacinação.

À Dra Marina Emiko Ivamoto Petlik, pelo estímulo e apoio, sobretudo por facilitar a difícil conciliação entre o trabalho e o doutorado.

À Lilian Santos de Godoy Prado e Marlene Goreti de Sales, pelo carinho e informações imprescindíveis durante todos os quatro anos em que estive no Departamento. 
Ao Departamento de Medicina Preventiva da USP pela oportunidade, confiança, estímulo e por me proporcionar grande aprendizado e ampliar meus horizontes no campo da Saúde Coletiva.

Ao Conselho Nacional de Desenvolvimento Científico e Tecnológico (CNPq), pelo incentivo à pesquisa mais ampla realizada.

Em especial, aos meus pais, por tudo. À minha querida mãe Marilena, pelo amor incondicional, pela dedicação sem limites, por eu ter chegado até aqui e por me ensinar ser uma pessoa melhor. Agradeço muitíssimo ao meu querido pai José Carlos, pelo amor e por me trazer o fascínio pela leitura e escrita, e o encantamento pela pesquisa e busca por conhecimento.

Às minhas queridas irmãs. Marta, pela importância da parceria de vida e pelos tantos momentos passados juntas, que me proporcionam muita alegria e enriquecimento sempre. Natália, pelo exemplo, carinho e compartilhamento das coisas da vida, profissionais e acadêmicas.

À minha querida avó Olivia (in memoriam), belíssima pessoa, mãe, mulher, avó, bisavó. Agradeço aos incontáveis momentos de total troca e aprendizado. Diante de tantos ensinamentos de vida que ela me proporcionou, ela me trouxe a importância de compartilhar o que se aprende com as pessoas e a preocupação com o social.

Ao meu avô Hugo (in memoriam), que me ensinou desde pequena a relevância e o valor do trabalho. À minha querida avó Francisca (in memoriam), que me enchia de orgulho por ser a primeira professora de uma cidade no interior paulista, por me ensinar desde sempre a importância do estudo.

Às crianças que passaram pela minha vida, em especial às queridíssimas Julia e Camila.

Por fim, ao meu amor, parceiro e amigo Gustavo, pela oportunidade de viver uma relação de companheirismo, intimidade e cumplicidade. Agradeço imensamente o amor, dedicação, paciência e apoio nesse percurso. 
“...temos o direito a ser iguais quando a nossa diferença nos inferioriza; e temos o direito a ser diferentes quando nossa igualdade nos descaracteriza. Daí a necessidade de uma igualdade que reconheça as diferenças e de uma diferença que não produza, alimente ou reproduza as desigualdades".

Boaventura de Souza Santos (2003: 56) 


\section{Sumário}

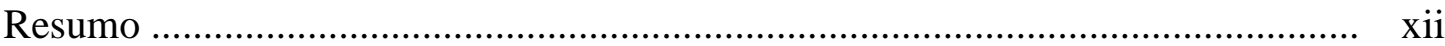

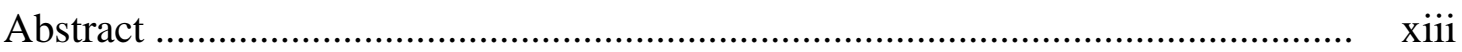

Apresentação ........................................................................................... xiv

1. Introdução e contextualização do tema ................................................ 01

1.1. O universo da vacina e os movimentos anti-vacinação ........................ 05

1.2. Cuidado e infância: o lugar da criança na família e sua interface com as práticas de saúde

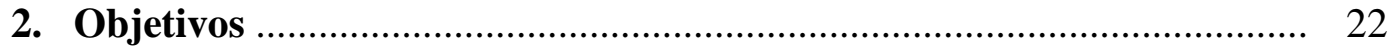

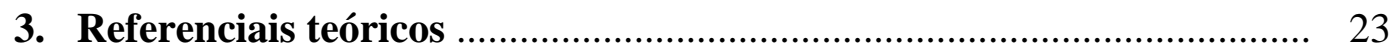

3.1. A perspectiva do cuidado ............................................................. 23

3.2. $\mathrm{O}$ universo das camadas médias urbanas ............................................ 26

3.2. A perspectiva de gênero nos estudos de família e saúde........................ 29

4. Método e campo da pesquisa …...................................................... 33

4.1. Aspectos éticos ........................................................................ 40

4.2. Percurso analítico-interpretativo ..................................................... 41

4.3. Impressões da pesquisadora-intérprete durante o trabalho de campo ... 46

5. Casais participantes …........................................................... 54

5.1. Casais que vacinaram os filhos ....................................................... 56

5.2. Casais que selecionaram as vacinas dos filhos ................................. 59

5.3. Casais que não vacinaram os filhos ............................................... 62

6. Tomada de decisão sobre a (não) vacinação dos filhos ......................... 66

6.1. A problematização da vacina no contexto do parto humanizado .......... 84

6.2. A informaçãa em saúde como divisor de águas .................................. 91

7. O cuidado infantil e a (não) vacinação ............................................. 102 
7.1. Justificativas pela não vacinação ....................................................... 113

7.2. A vacinação infantil: entre o risco e a proteção .................................... 128

8. A (não) vacinação na vida privada .................................................... 139

8.1. Parentalidade e a "nova paternidade": uma questão relacional ............. 147

8.2. Parentalidade nos cuidados em saúde da criança: um lugar feminino e a permanência do ideário da "boa mãe".

8.3. A relação conjugal e a (não) vacinação dos filhos: entre a confiança e a corresponsabilização

8.4. As relações entre as gerações e a (não) vacinação infantil .................... 166

9. A vacinação infantil: reflexões sobre a relação indivíduo-coletivo ....... 172

10. Considerações finais ........................................................................ 192

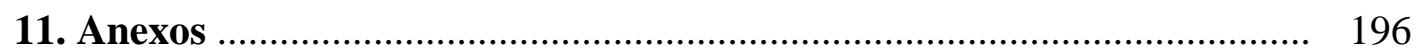

Anexo 1. Roteiro da entrevista em profundidade ..................................... 196

Anexo 2. Termo de Consentimento Livre e Esclarecido ............................. 197

Anexo 3. Parecer do Comitê de Ética em Pesquisa ...................................... 198

12. Referências bibliográficas ......................................................... 199 


\section{Resumo}

Barbieri CLA. Cuidado infantil e (não) vacinação no contexto de famílias de camadas médias em São Paulo/SP [tese]. São Paulo: Faculdade de Medicina, Universidade de São Paulo; 2014.

A vacinação é uma das medidas de maior impacto na diminuição da morbimortalidade de doenças. No entanto, sua história é marcada por êxitos e contratempos. No contexto brasileiro, a vacinação se afirmou como premissa do cuidado infantil, extrapolando a perspectiva médica e alcançando a população geral. Em contraponto, desde os anos 2000, foi observada uma diminuição da cobertura vacinal infantil em estratos de alta renda e escolaridade em São Paulo-SP, segmento social que valoriza a individualidade e a autonomia dos sujeitos. Esse estudo tem por objetivo compreender o processo de (não) vacinação dos filhos e sua interface com o cuidado infantil, em casais de camada média e alta escolaridade em São Paulo/SP. Foi utilizada a abordagem qualitativa, por meio de entrevistas em profundidade com dezesseis casais, dos quais cinco vacinaram, cinco selecionaram as vacinas e seis não vacinaram os filhos. $\mathrm{O}$ percurso analíticointerpretativo dos dados empíricos foi realizado pelo referencial metodológico da antropologia interpretativa geertziana com o recurso da análise de conteúdo temático e os achados foram discutidos em articulação com os referenciais teóricos interrelacionados de cuidado, família e gênero. $\mathrm{O}$ estudo encontrou diferenças significativas quanto à tomada de decisão dos casais, variando de uma postura de aceitação plena a uma questionadora, porém, todos eles convergiram nos aspectos de buscar argumentação científica e orientação médica para suas escolhas. $\mathrm{O}$ contexto do parto humanizado e as informações sobre vacina, sobretudo da internet, foram os principais elementos que deflagraram a problematização da vacina, com destaque ao protagonismo feminino nesse percurso. Apesar das diferentes concepções acerca da vacinação, para todos os casais, a escolha por vacinar ou não o filho baseou-se no mesmo sentimento de cuidado parental e valores de proteção e responsabilidade. A vacinação assumiu significado de proteção para os que vacinaram e risco para os que não vacinaram. As justificativas pela não vacinação se assemelharam às da literatura internacional. As decisões sobre vacinação e saúde no âmbito privado familiar foram majoritariamente apropriadas pelas mulheres, a despeito de evidências de uma maior participação dos homens nos afazeres domésticos e no cuidado filial. Os casais que não vacinaram relataram sentimento de medo diante da possibilidade de perda da autonomia nas decisões sobre a saúde de seus filhos. A defesa dessa autonomia, porém, não foi estendida a toda população. Todos os casais participantes, independentemente da postura quanto à vacinação, tomaram suas decisões norteadas por uma perspectiva individual, não sendo mencionada a função coletiva da imunização. A compreensão da aceitabilidade das vacinas na sua interface com o cuidado infantil, no contexto das camadas médias de São Paulo, remete a uma reflexão sobre a interação sociedade e práticas de saúde e ressalta a importância que o cuidado, no tocante à vacinação, é uma questão que extrapola o âmbito individual, pois diz respeito a uma responsabilidade que também é coletiva.

Descritores: 1.Vacinação 2.Saúde da criança 3.Cuidado infantil 4.Família 5.Camada média 6.Gênero e saúde 


\begin{abstract}
Barbieri CLA. Child care and (not) vaccination in the context of middle class families in São Paulo/SP [thesis]. São Paulo: Faculdade de Medicina, Universidade de São Paulo; 2014.

Vaccination is one of the measures of greatest impact in reducing the morbiditymortality of diseases. However, its history is scarred by successes and setbacks. In the Brazilian context, vaccination consolidated itself as the premise of child care, exceeding the medical perspective and reaching out the population in general. In contrast, it has been observed since the 2000s, a diminishing of infant immunization coverage in highincome strata and education in São Paulo-SP, a social segment that values the individuality and autonomy of individuals. This study aims to understand the process of (not) vaccination of children by couples in middle and high schooling level in São Paulo-SP, and its interface with child care. A qualitative approach through in-depth interviews with sixteen couples was employed. Among them: 05 vaccinated their children, 05 selected the vaccines and 06 did not vaccinate their children. The analytical and interpretative path of empirical data was performed by methodological framework of geertzian interpretative anthropology, with the use of thematic content analysis, and the findings were discussed in conjunction with the interrelated theoretical frameworks of care, family and gender. The study found significant differences concerning the decision making process of the couples, ranging from a position of full acceptance to questioning the vaccination itself, however, all of them converged on aspects of seeking scientific argumentation and medical advice to guide their choices. The context of humanized childbirth and information on vaccine, mostly from the internet, were the main elements that triggered the questioning of the vaccine, particularly the female role in this pathway. Despite distinct views about vaccination, for all couples, the choice to vaccinate or not the child was based on the same sense of parental care, protection values and responsibility. Vaccination assumed a meaning of protection for those who vaccinated and a risk for those who did not vaccinate. The reasons for the nonvaccination were similar to those reported in the literature. Decisions about vaccination and health in the family scope were mostly appropriated by women, despite evidences of a greater participation of men in the housework and child care. Couples who did not vaccinate reported a sense of fear under losing the autonomy of taking decisions on their children`s health. The defense of this autonomy, however, did not reach the entire population. All attendant couples, regardless of vaccination stance, made their decisions guided by an individual perspective, not mentioning the collective function of immunization. Understanding the acceptability of vaccines and its interface with child care in the context of the middle class of São Paulo, points to a reflectance on the relationship between society and health practices and emphasizes the importance that care, with regard to vaccination, is a question that goes beyond the individual scope, as it relates to a responsibility which is also collective.
\end{abstract}

Descriptors: 1.Vaccination 2.Child health 3.Child care 4.Family 5.Middle class 6.Gender and health 


\section{Apresentação}

No decorrer da minha formação médica, em meio a um universo marcado pelo enfoque nas patologias e pela perspectiva biológica, a sensação de desajuste e desconforto amenizaram quando me deparei com as disciplinas de puericultura e epidemiologia, que privilegiaram, cada qual a sua maneira, a busca pela saúde e não apenas a cura da doença. Neste momento, decidi fazer residência em pediatria e, posteriormente, pós-graduação na Medicina Social e Preventiva (desconhecia até então o campo da Saúde Coletiva).

Após a residência de pediatria, no segundo ano da especialização em infectologia pediátrica, um alento surgiu durante um estágio no Centro de Referência de Imunobiológicos Especiais (CRIE) do Hospital das Clínicas de São Paulo em 2009. Nele aprendi muito sobre vacinação com as Profas. Dras. Marta Heloísa Lopes e Ana Marli Christovam Sartori. E foi nele também a origem do meu interesse pelo assunto, uma vez que a temática da vacinação resgatava a dimensão da saúde e a interface da clínica pediátrica e da saúde coletiva por mim desejada; além de me suscitar, por outro lado, algumas inquietações.

A primeira, como pediatra e quase infectopediatra, surgiu do meu espanto frente ao desconhecimento que eu tinha sobre as vacinas. A vacinologia se revelou como um mundo à parte, rico e fascinante, e que as poucas aulas sobre vacina/vacinação na faculdade se mostraram insuficientes para dar conta de explorar esse campo crescente. A segunda, nesse mesmo período, se deu quando me deparei com pessoas, parentes e do meu círculo social, que eram contra as vacinas, com as quais reagi primeiramente com muita indignação. Esses fatores fizeram com que eu iniciasse um amplo estudo sobre vacinação, me encantando cada vez mais com essa temática.

Neste percurso, fiquei com duas perguntas que poderiam ser as bases de uma futura pós-graduação, a primeira, qual era o conhecimento dos médicos sobre vacinação; e a segunda, porque algumas pessoas eram contra a vacinação. Nessa época, acessei os estudos de inquérito vacinal da equipe do Prof. Dr. José Cássio de Moraes, que demonstraram uma diminuição na cobertura vacinal infantil em famílias do estrato de maior nível socioeconômico e renda. 
Foi durante o curso da disciplina "Pesquisa Aplicada à Infecção por HIV/Aids: Abordagens, Métodos e Técnicas", sob a responsabilidade dos Profs. Drs. Aluísio Augusto Cotrim Segurado, Ana Marli Christovam Sartori e Eliana Battaggia Gutierrez, como aluna ouvinte em novembro de 2009, na aula sobre pesquisa qualitativa ministrada pelo Prof. Dr. José Ricardo de Carvalho Mesquita Ayres e pela Profa. Dra. Vera Silvia Facciolla Paiva, que compreendi que minhas inquietações poderiam ser melhor exploradas por meio da então desconhecida abordagem qualitativa.

Por intermédio do Prof. José Ricardo, conheci a Profa. Dra. Márcia Thereza Couto Falcão, que tinha como linha de pesquisa principal estudos sobre gênero e saúde, masculinidade e família. Após nossa primeira conversa, vimos a possibilidade de convergência da minha questão acerca da vacinação ou não dos filhos, no segmento social mais privilegiado, com a linha de família e gênero, na perspectiva socioantropológica. Após seu aceite, desenhei um projeto intitulado "Parentalidade e cuidado: representações de pais e mães acerca da vacinação dos filhos", e entrei no Mestrado pelo Programa Medicina Preventivo em 16 de junho de 2010.

Desenvolvi o trabalho de campo no primeiro semestre de 2011, que foi ao mesmo tempo desafiador e enriquecedor. Quase que semanalmente fui à procura da minha orientadora compartilhar a fartura e riqueza dos dados das entrevistas, que me instigavam, mas também me traziam certa angústia, em não saber como lidar com todo aquele material empírico. Os depoimentos, apesar de norteados por um roteiro amplo e aberto sobre o processo de (não) vacinação e o cuidado, trouxeram muito mais que essa dimensão no interior da família, conforme a proposta inicial, como os aspectos do risco e vacinação, autonomia nas decisões em saúde, a informação de saúde, as práticas de saúde obstétricas e materno-infantil, entre outros temas.

Diante disso, ampliamos o estudo do cuidado em saúde infantil para outras temáticas além da vacinação, como o aleitamento materno e alimentação da criança. $\mathrm{O}$ projeto mais amplo foi intitulado "Gênero, parentalidade e cuidado: representações de pais e mães de camada média urbana acerca da amamentação, alimentação e vacinação de seus filhos", sobre a responsabilidade da Profa. Dra. Márcia Thereza Couto Falcão; e contou com o apoio financeiro do Conselho Nacional de Desenvolvimento Científico e Tecnológico $(\mathrm{CNPq})$, modalidade Edital Universal de Pesquisa, processo 
(480024/2011-1), com vigência de fevereiro de 2012 a abril de 2014. Assim, o presente estudo passou a posteriori, a fazer parte de um recorte desse projeto maior.

Outra derivação da riqueza dos dados empíricos foi a passagem do mestrado, para o doutorado direto, por sugestão da orientadora em conjunto com o Prof. Dr. Paulo Rossi Menezes, coordenador da Pós-graduação do Departamento de Preventiva da FMUSP; mudança que foi aprovada pela banca de qualificação em 01 de março de 2012. A mudança para o programa de doutorado direto permitiu o aprofundamento do material empírico, que culminou na presente tese. 


\section{INTRODUÇÃO E CONTEXTUALIZAÇÃO DO TEMA}

As transformações das práticas de saúde atuais e sua relação com mudanças mais amplas da sociedade, na apreensão da articulação da medicina - prática técnica cientificista, e ao mesmo tempo, de desenvolvimento dinâmico histórico-social - com as práticas sociais (Donnangelo, 1976), compõem um cenário complexo e multifacetado, porém, necessário para que se possa compreender o lugar que o cuidado em saúde infantil e a vacinação assumem na contemporaneidade.

A complexidade do processo saúde-doença-intervenção revela-se no conflito entre os êxitos da medicina tecnológica, pautada no acelerado desenvolvimento técnicocientífico, que permitiu o aumento da precisão, rapidez dos diagnósticos e de intervenções terapêuticas, a queda da morbimortalidade e a maior expectativa de vida da população (Ayres, 2003); e a "crise de confiança" das práticas de saúde atuais (Schraiber, 2008), em que esses avanços culminaram numa remodelação relacional, com o distanciamento da dimensão intersubjetiva entre indivíduos/populações e profissionais de saúde/gestores (Ayres, 2003, 2004; Schraiber, 2008).

A (ultra)especialização e o tecnicismo da medicina desde 1960 - que propiciou a transição da prática profissional médica liberal e artesanal para empresarial e tecnológica - abalou a confiança e reconfigurou as diversas interações e relações entre os sujeitos (Schraiber, 2008), incluindo a relação de indivíduos e grupos com as técnicas médicas. Nesse contexto, uma importante ferramenta de prevenção médica, sobretudo no campo da saúde da criança, a imunização infantil, tornou-se um exemplo emblemático que corporificou o conflito mais amplo das práticas em saúde atuais.

Os progressivos avanços no conhecimento e tecnologias na área da vacinologia, os êxitos das políticas públicas de imunização e a queda da morbimortalidade por doenças imunopreveníveis convivem com a heterogeneidade da cobertura vacinal conforme região e nível socioeconômico (Barata et al., 2012; Domingues; Teixeira, 2013), o ressurgimento de doenças controladas como o sarampo (CVE, 2014), e a resistências e reações sociais contrárias, sobretudo em países da Europa Ocidental e da América do Norte (Bedford; Elliman, 2000), revelando tensões e confluências entre a medicina como prática clínica-terapêutica e de saúde pública/coletiva e a medicina 
como ciência, "inclusive quando utiliza meios cuja eficácia esteja cada vez mais garantida cientificamente" (Donnangelo, 1976: 16).

A imunização ativa por meio das vacinas é uma técnica preventiva eficaz e com elevada relação benefício/custo contra doenças infecciosas imunopreveníveis. É considerada, segundo referencial biomédico e da saúde pública/coletiva, a segunda intervenção de maior impacto na diminuição de morbimortalidade da população (superior à descoberta de antibióticos), perdendo somente para o saneamento básico e água potável (Plotkin et al., 2008).

Sobretudo a partir da segunda metade do século XX, a vacinação no Brasil se intensificou e se difundiu nacionalmente por meio de campanhas de vacinação específicas, como a campanha de erradicação da varíola entre 1967 e 1980, e a vacinação em massa no país (Hochman, 2011). Nessa trajetória, em 1973 foi criado o Programa Nacional de Imunização (PNI), institucionalizado pela Lei no 6.259 em 30 de outubro de 1975, com objetivo de coordenar ações sistemáticas e ordenadas de vacinação em esfera nacional, e intensificar as atividades de imunização no país, em quantidade e qualidade (Brasil, 2003; Domingues; Teixeira, 2013).

Desde então, a política de imunização do Ministério da Saúde conquistou e vem conquistando importantes passos para a efetividade de suas ações, entre eles destacamse: a descentralização da execução (mantendo a verticalização da coordenação e das normas técnicas); alto investimento (aumento em até 5 vezes desde 1997), cujo financiamento é $100 \%$ de origem pública para garantir a continuidade das ações e autonomia financeira; introdução de novas vacinas; o início da produção nacional de vacinas a partir de 1999 (produção doméstica de mais de 96\% das vacinas e exportação de vacinas contra febre amarela e meningite), hoje com certificação internacional de qualidade, conferindo-lhe autonomia e sustentabilidade; e, por fim, o aumento progressivo da cobertura vacinal, mesmo diante da extensão territorial do país (Brasil, 2003; Domingues; Teixeira, 2013).

O PNI conquistou no país um lugar de prestigio e reconhecimento nacional e internacional (Paim et al., 2011; Barreto et al., 2011), fornecendo de forma gratuita e universal grande quantidade de vacinas à população infanto-juvenil, um dos calendários públicos mais vasto do mundo. Nos últimos anos, entraram no calendário a vacina difteria, tétano e coqueluche associada à Haemophilus influenza tipo B (tetravalente) em 
2002; a contra rotavírus em 2006; a contra pneumococo e meningococo C em 2010 (Domingues; Teixeira, 2013); a vacina contra poliomielite inativada (VIP) para as duas primeiras doses, no lugar da vacina contra poliomielite oral (VOP), e a vacina pentavalente (agrupamento da tetravalente com a hepatite B) em 2012 (CGPNI, 2012 a, b); a vacina contra o HPV e varicela (incluída na vacina tetraviral) em 2014 e a programação de introdução da vacina contra a hepatite A no segundo semestre de 2014 (CGPNI, 2013 a, b, c). Desse modo, em 2014, o PNI oferece imunização contra 18 doenças para crianças e adolescentes (15 doenças no calendário básico para criança de até 1 ano de idade)1. O PNI também oferece vacinas aos idosos, gestantes, adultos em geral e para pessoas com condições associadas ao aumento do risco de adoecimento e/ou de maior gravidade dessas infecções (Domingues; Teixeira, 2013).

A história recente da imunização no país, potencializada pelo percurso exitoso do PNI, conduziu à emergência da "cultura de imunização" no Brasil contemporâneo descrita por Hochman (2011). Nesse contexto nacional, a vacinação na criança no país adquiriu um lugar associado ao cuidado infantil, que extrapolou a perspectiva da biomedicina e da saúde pública/coletiva, e atingiu a população em geral e o universo da família.

Em contrapartida à cultura de imunização do Brasil e aos avanços do PNI, incluindo o aumento progressivo da cobertura vacinal, estudos epidemiológicos realizados no Município de São Paulo, a partir dos anos 2000, - utilizando inquérito domiciliar e estratificação por conglomerados (estratos de A a E de acordo com indicadores de moradia, escolaridade, saneamento básico e renda, obtidos pelo censo demográfico) - mostraram uma tendência de queda da cobertura vacinal nos estratos de maior nível educacional e socioeconômico (Moraes et al., 2000, 2003; Moraes; Ribeiro, 2008; Waldman, 2008; Barata et al., 2012). Os estudos realizados na cidade de São Paulo, em 1998 e 2002, mostraram um discreto aumento da cobertura vacinal geral de 1998 a 2002, mas evidenciaram uma mudança de padrão conforme a distribuição por estratos: houve tendência de aumento da cobertura vacinal conforme a piora do estrato

\footnotetext{
${ }^{1}$ No calendário básico para crianças de até um ano de idade: BCG, contra hepatite B, difteria, tétano, coqueluche, Haemophilus influenzae B, rotavírus, poliomielite, pneumococo, meningococo C, sarampo, caxumba, rubéola, gripe e febre amarela (esta não de forma universal, apenas para áreas de risco). Após um ano de vida, a vacina contra o varicela com 15 meses, a contra HPV na pré-adolescência, e a programação de introdução da vacina contra a hepatite A no segundo semestre de 2014 (Domingues; Teixeira, 2013; CGPNI, 2013 a, b, c).
} 
socioeconômico e, por conseguinte, uma diminuição da cobertura vacinal no estrato A (Moraes et al., 2000, 2003; Moraes; Ribeiro, 2008). No estudo de 2007, realizado nas 27 capitais do país, essa tendência - propensão inversamente proporcional da taxa de vacinação e o nível socioeconômico - foi evidenciada em dez capitais ${ }^{2}$, incluindo São Paulo, onde a taxa de cobertura vacinal encontrada no estrato A foi significativamente menor que a no estrato $\mathrm{E}$ (Barata et al., 2012).

No passado, as baixas coberturas vacinais eram mais evidentes nas camadas mais pobres, e explicadas pela dificuldade de acesso aos serviços de saúde e falta de informação. Porém, essa tendência de menor cobertura vacinal em camadas mais privilegiadas e escolarizadas evidencia uma mudança da acessibilidade para aceitabilidade e legitimidade dessa medida médica e de saúde pública por alguns setores da sociedade (Waldman, 2008).

Essas recentes evidências oriundas de estratos de alta escolaridade e rendimento, num país em que a vacinação é historicamente cultuada como parte importante do cuidado em saúde infantil, apesar de aparentemente não abalar os êxitos do PNI, pode justificar em parte o aumento dos surtos de sarampo no país nos últimos anos (CVE, 2014). E mais que isso, elas podem revelar o questionamento da aceitação das vacinas, ou melhor, a problematização da vacinação infantil como premissa do cuidado em saúde da criança, como hegemonicamente era e é cultuada, por uma parcela da população.

Diante do cenário particular da vacinação no Brasil e a tendência recente de queda da cobertura vacinal infantil nos estratos de maior renda e escolaridade, este estudo tem como questão principal a compreensão da interface entre o processo de escolha pela (não) vacinação dos filhos e o cuidado infantil (em saúde) em famílias de alta escolaridade pertencentes às camadas médias de São Paulo-SP.

Serão apresentados, a seguir, um breve resgate histórico sobre o universo da vacina e dos movimentos anti-vacinação e sobre o lugar que a infância assumiu na interface família e práticas de saúde, a fim de explorar o objeto de estudo dessa pesquisa.

\footnotetext{
${ }^{2}$ São Paulo (SP), Rio de Janeiro (RJ), Belo Horizonte (MG), Curitiba (PR), Florianópolis (SC), Goiânia (GO), Palmas (TO), Recife (PE), Maceió (AL) e Natal (RN).
} 


\subsection{O universo da vacina e os movimentos anti-vacinação}

A primeira vacina ${ }^{3}$, contra a varíola, foi descoberta no final do século XVIII por Edward Jenner, mas foi a partir de meados da década de 1920, que a imunização foi realizada como rotina estendida à população em diversos países, incluindo o Brasil. Desde então o desenvolvimento de vacinas e o aprimoramento de sua tecnologia ganhou muito espaço como uma ferramenta médica e de saúde pública e despertou grande interesse mundial, de organizações de saúde, governo até a indústria farmacêutica (Plotkin et al., 2008).

Após a vacina contra varíola (criada em 1798), no século XIX veio a descoberta da vacina contra raiva por Pasteur (1885); e na primeira metade do século XX foi desenvolvida a vacina contra difteria (1923), tétano (1926), coqueluche (1926), tuberculose (BCG, em 1927) e febre amarela (1935). Já na segunda metade do século $\mathrm{XX}$, além do avanço tecnológico e a busca por vacina com alta eficácia e baixa reatogenicidade - como o recurso da engenharia genética - foram criadas as vacinas contra poliomielite, sarampo, caxumba e rubéola, varicela (a catapora), hepatite A e B, e contra bactérias encapsuladas: pneumococo, meningococo e Haemophilus influenzae tipo B. Já no século XXI, além da vacina contra varicela zoster e HPV, houve a tendência de agrupar várias vacinas numa mesma aplicação, as vacinas polivalentes (Plotkin et al., 2008).

Em paralelo ao avanço científico e tecnológico na área, as políticas de imunização apoiadas pela Organização Mundial da Saúde (OMS) expandiram globalmente, resultando na erradicação global da varíola em 1979; na erradicação do vírus selvagem da poliomielite nas Américas e diminuição de $99 \%$ da doença no mundo; além do controle de diversas doenças como febre amarela, difteria, tétano, coqueluche, doenças pelo Haemophilus influenza tipo B, sarampo, caxumba, rubéola e raiva (Plotkin et al., 2008).

No Brasil, a vacinação contra a varíola chegou em 1804 de maneira irregular e aplicada inicialmente em escravos (Lopes; Polito, 2007). A vacinação antivariólica no país foi declarada obrigatória por lei em 1837 para crianças e em 1846 para adultos;

\footnotetext{
${ }^{3}$ O termo vacina vem da palavra vaca, originário da descoberta de Jenner que a varíola bovina podia proteger o ser humano da varíola humana, publicado em 1798, sob o título Variolae Vaccinae, ou seja a varíola da vaca (Plotkin et al., 2008).
} 
prática, porém, que não foi cumprida neste século por falta de condições técnicas (principalmente referente à produção insuficiente), de logística e má aceitação da população frente à ideia de inoculação em seu corpo do vírus que causa a doença (Porto, 2003). Diante de uma epidemia de varíola que afligia a então capital federal em 1904, a cidade do Rio de Janeiro, Oswaldo Cruz (na época Diretor Geral de Saúde Pública, cargo hoje correspondendo ao de Ministro da Saúde) e sua comissão reinstauraram a obrigatoriedade da vacina antivariólica e a instituíram de forma compulsória, que culminou na Revolta da Vacina (Porto, 2003; Moulin, 2003; Sevcenko, 1993).

Estudiosos da Revolta da Vacina apontam que a reação de indignação popular pela campanha de vacinação em massa não foi por si só, a responsável pela gravidade e violência da revolta. Compreendida como um contexto, pretexto, trampolim ou um papel secundário, Cukierman relata que "a 'vacinalidade' da Revolta teria pouco ou nada a acrescentar. Portanto não é demasiado afirmar que na sua historiografia, a Revolta da Vacina aparece como Revolta sem Vacina!” (2007: 241). Para além de uma rejeição à vacina ou ao modo autoritário em que foi realizada, ela foi explorada por grupos oposicionistas ao Governo de Rodrigues Alves, sobretudo aqueles a favor de Floriano Peixoto (jacobinos ou florianistas) e os monarquistas, que viram na reação popular uma oportunidade de golpe. Além dos interesses políticos, são relatadas questões de ordem moral como a baixa aceitação da exposição de parte do corpo das mulheres aos agentes da vacina, ferindo a virtude da mulher e a honra do chefe de família; de ordem socioeconômica, como a pobreza e o alto índice de desemprego e como resposta à postura autoritária da reforma urbana no centro do Rio de Janeiro que discriminou a população mais carente (Sevcenko, 1993; Moulin, 2003; Cukierman, 2007).

Apesar desse curioso episódio brasileiro, chama a atenção a ausência de relatos de reação contrária às vacinas no país nos anos seguintes (Hochman, 2011). Hochman acredita que as ações nacionais públicas para o combate da varíola, estimulada pela OMS, sobretudo nas décadas de 1960 e 1970 - a introdução progressiva de vacinas disponíveis à população, a vacinação em massa e as campanhas nacionais de vacinação - que resultaram na erradicação da varíola no país; estratégias potencializadas pelo marketing, vacinação de pessoas notórias e eventos em praça pública num período de repressão política, foram determinantes para a emergência da "cultura de imunização" no Brasil contemporâneo. Esse processo, somado à progressiva conquista por um dos 
calendários vacinais mais amplos oferecidos de forma gratuita e universal à população infantil, fez com que o PNI se sobressaísse como uns dos programas públicos de grande credibilidade (Hochman, 2011; Paim et al., 2011; Barreto et al. 2011), cuja qualidade e o avanço na acessibilidade desse vasto conjunto de vacinas o destacou, diante de outros programas públicos, como um "promotor de equidade"4 em saúde.

No âmbito legal, a vacinação obrigatória no Brasil é prevista por lei. Após a criação do PNI em 1973, suas ações, coordenadas pelo Ministério da Saúde, foram normatizadas pela Lei ordinária n. 6.259/1975 de 30 de outubro de 1975, que 'dispõe sobre a organização das ações de Vigilância Epidemiológica, sobre o Programa Nacional de Imunizações, estabelece normas relativas à notificação compulsória de doenças, e dá outras providências' (Brasil, 1975). Essa lei foi regulamentada pelo Decreto n. 78.231, de 12 de agosto de 1976, que estabeleceu, dentre outros preceitos, a obrigatoriedade das vacinas, como descrito nos seguintes artigos:

Art 27. Serão obrigatórias, em todo o território nacional, as vacinações como tal definidas pelo Ministério da Saúde, contra as doenças controláveis por essa técnica de prevenção, consideradas relevantes no quadro nosológico nacional.

Art 29. É dever de todo cidadão submeter-se e os menores dos quais tenha a guarda ou responsabilidade, à vacinação obrigatória.

Parágrafo único. Só será dispensada da vacinação obrigatória, a pessoa que apresentar Atestado Médico de contraindicação explícita da aplicação da vacina (Brasil, 1976).

Também no âmbito legal, foi criado o Estatuto da Criança e do Adolescente (ECA) - Lei 8.069 no dia 13 de julho de 1990 - que regulamentou o artigo 227 da Constituição da República Federativa do Brasil de 1988, visando estabelecer os direitos e a proteção integral à população infanto-juvenil. O ECA estabelece que "é obrigatória a vacinação das crianças nos casos recomendados pelas autoridades sanitárias" (Brasil, 1990, artigo 14, § único).

$\mathrm{Na}$ esfera da biomedicina, a postura de não vacinar os filhos conforme desejo dos pais, sem que isso seja uma contraindicação de ordem técnica, é referida como um

\footnotetext{
${ }^{4}$ Fala do secretário de Vigilância em Saúde do Ministério da Saúde, Jarbas Barbosa, na ocasião do fórum "Construindo um País mais Saudável - 40 Anos do Programa Nacional de Imunizações", evento realizado em 04 de setembro de 2013 em Brasília: "Temos um Programa descentralizado que é fundamental para que todos possam ter acesso à mesma oferta de vacinas. O PNI é um promotor de equidade”. Disponível em: < http://www.acaoresponsavel.org.br/40anospni/images/realese_posevento.pdf> Acesso em 13 de maio de 2014.
} 
possível caso de negligência parental ou "omissão do cuidar", pois representaria uma recusa a uma conduta comprovadamente benéfica à criança, como pode ser demonstrado no "Manual de atendimento às crianças e adolescentes vítimas de violência" da Sociedade de Pediatria de São Paulo e do Conselho Federal de Medicina.

Cabe discutir quando os pais se recusam a aceitar uma conduta claramente benéfica para seus filhos, como as vacinas, por exemplo. Nessa circunstância, o melhor interesse do menor deve prevalecer e a responsabilidade do médico e da instituição hospitalar existe independente da dos pais. Portanto, havendo ou não culpa dos pais ou responsáveis, faz-se necessária a notificação e a tomada de decisão a favor da proteção desse menor, que está sofrendo situação de desamparo (CFM, 2011: 46).

Em resposta à duvida de um médico no Paraná/PR em como proceder no caso de atender pais que não vacinam os filhos, o Conselho Regional de Medicina do Paraná, em 2001, responde em parecer $n^{\circ} 1345 / 01-$ CRMPR $^{5}$ :

Ao se decidirem contrários à vacinação de seus filhos, sem causa médica justificável, estarão os pais infringindo o Estatuto da Criança e do Adolescente e sujeitos às medidas cabíveis nestes casos, conforme descrito no art. 98: As medidas de proteção à criança e ao adolescente são aplicáveis sempre que os direitos reconhecidos nesta Lei forem ameaçados ou violados: I - por ação ou omissão da sociedade ou do Estado; II - por falta, omissão ou abuso dos pais ou responsável; III em razão de sua conduta.

Nós brasileiros e principalmente, nós, profissionais de saúde, neste início do século XXI, não podemos esquecer quantas crianças e adultos morreram, não muito tempo atrás, de doenças que agora são preveníveis por uma política de imunização efetiva. Muitos outros países não têm tal condição e pólio, sarampo, coqueluche e difteria, entre outras doenças infecciosas, ainda causam devastação na população, especialmente de baixa idade. Com a globalização, a prevenção das doenças infecciosas não está apenas no nosso território e os riscos de reintrodução destas doenças em nosso meio são permanentes. Por esta e outras razões acima mencionadas, a manutenção de altas taxas de cobertura vacinal é essencial para preservação da saúde e prevenção das doenças imunopreveníveis.

É louvável a preocupação do Dr. J. M. F., preocupação que ultrapassa os limites de seus interesses individuais, incluindo os da criança sob

\footnotetext{
${ }^{5}$ Conselho Regional de Medicina do Paraná. Parecer n. 1345/01-CRMPR, consulta n. 016/01, protocolo $n^{\circ} 820 / 01$, assunto: vacinas - recusa dos pais da criança, parecerista Conselheira Mariângela Batista Galvão Simão. Disponível em: <///home/dell/Documentos/Artigos\%20da\%20literatura/Vacina\%C3\%A7 \%C3\%A3o/Parecer\%20CRM-PR\%201345\%202001\%20pais\%20n\%C3\%A3o\%20vacinadores.htm> Acesso em 07 de junho de 2014.
} 
os seus cuidados. Ao se deparar com tal situação, uma vez esgotados todos os argumentos técnicos na tentativa de convencimento dos pais ou responsáveis, acredito ser dever do médico o registro em prontuário e a notificação das autoridades sanitárias.

Apesar da existência da lei e do posicionamento biomédico, a alta cobertura vacinal no Brasil parece estar mais relacionada à cultura de imunização no país contemporâneo do que pela imposição $\operatorname{legal}^{6}$ (Hochman, 2011). Essas estratégicas públicas de vacinação, acrescidas da extensão, efetividade e credibilidade conquistada pelo PNI proporcionou no Brasil a quase inexistência de movimentos sociais antivacinação após a Revolta da Vacina, em que desconfianças e posições contrárias tinham um caráter mais individual do que uma mobilização social, diferente do que ocorreu em países como Inglaterra e EUA, o que reforça a legitimidade dessa medida preventiva no país (Holchman, 2011).

Os primeiros movimentos anti-vacinação iniciaram-se na Europa, principalmente na Inglaterra, decorrentes da medida pública de vacinação compulsória antivariólica, na segunda metade do século XIX e início do século XX (Wolfe; Sharp, 2002). O movimento anti-vacinação moderno, por sua vez, reacendeu também na Inglaterra, a partir de 1998, com a publicação de Wakefield et al. (1998), a qual mostrou uma associação da vacina MMR (sarampo, caxumba e rubéola) com autismo e inflamação intestinal. $\mathrm{O}$ estudo gerou uma publicidade desproporcional, atingindo os meios de comunicação em massa, como a televisão e posteriormente a internet, gerando uma queda imediata da cobertura vacinal e novos surtos de sarampo na Inglaterra e depois em outros países (Bedford; Elliman, 2000).

Diante das evidências de estudos ecológicos, epidemiológicos e virológicos posteriores não encontrarem associação entre a vacina MMR e o autismo, em 2003 o jornalista Brian Deer iniciou uma investigação sobre a veracidade do estudo de Wakefield et al. Foi constatado que este não tinha base científica e foi considerado

\footnotetext{
${ }^{6}$ Porém, é interessante relatar pelo teor inusitado, uma situação que ocorreu em 23 de setembro de 2013 , Ação Civil Pública inédita no país, procedente de Tribunal de Justiça do Estado de São Paulo, Comarca de Jacareí (fundamentada no artigo 273, do Código de Processo Civil, artigo 213, §1 do ECA), que determinou que um casal que não vacinou seus filhos - o qual alegou ser adepto da homeopatia, não confiar na eficácia da intervenção e a mãe ter história de morte do irmão pela vacina - vacinassem seus filhos num prazo de até 5 dias e, em caso de descumprimento, foi fixado multa diária no valor de um salário mínimo. Tribunal de Justiça do Estado de São Paulo. Comarca de Jacareí. Processo número 0012994-09.2013.8.26.0292. Disponível em: < http://www.mpsp.mp.br/portal/pls/portal/docs/1/2423200 .PDF> Acesso em 25 de fevereiro de 2014.
} 
fraudulento $^{7}$ : apresentou viés de seleção, em que parte das crianças já possuíam alteração no desenvolvimento antes da vacina e foram recrutadas por ativistas antiMMR; cronologia entre os sintomas e a vacina não corresponderam às encontradas nos prontuários dos pacientes; alteração dos laudos prévios e fraude no diagnóstico de autismo (Godlee et al., 2011).

Enquanto aumentavam-se as evidências da ausência de associação da MMR com autismo, ativistas anti-vacinação transferiram a acusação da vacina MMR para o timerosal, um conservante à base de mercúrio, que evita a proliferação de bactéria usado em frascos de vacinas com múltiplas doses desde os anos 1930. As evidências que o mercúrio ambiental (metilmercúrio) em doses elevadas poderia gerar danos cerebrais foram usadas nas críticas ao timerosal, que é um etilmercúrio (Offit, 2008). A ausência de estudos sobre os malefícios do etilmercúrio (cuja literatura científica contava apenas com estudos que avaliavam os efeitos do metilmercúrio) e rejeição das vacinas que continham timerosal por grupos anti-vacinação nos EUA e em países da Europa, geraram uma mobilização social que protestaram a favor de retirar o timerosal na confecção das vacinas, o que foi atendido pelas agências reguladoras desses países (Offit, 2008). No Brasil, o timerosal ainda está presente nas vacinas com frasco de multidoses fornecidas nos serviços públicos, onde a Agência Nacional de Vigilância Sanitária (ANVISA) regulamenta o nível máximo permitido, tanto para a produção nacional, quanto pelas vacinas compradas por indústrias farmacêuticas (ANVISA, 2001).

Tais fatos corroboraram para o desencadeamento de um crescente movimento anti-vacinação na Europa, EUA, Canadá, Japão, Austrália, entre outros países, manifestando-se principalmente através de sites e blogs (Poland; Jacobson, 2001). Em paralelo, o sucesso dos programas de vacinação levou a uma queda das doenças imunopreveníveis e, por ironia, a uma maior visibilidade dos efeitos adversos das vacinas, que corroborou sinergicamente para o fortalecimento destes movimentos (Bedford; Elliman, 2000).

Não obstante os movimentos anti-vacinação do século XIX/XX e do início do XXI terem gêneses diferentes, alguns autores revelam "estranhas" semelhanças sobre os

\footnotetext{
${ }^{7}$ Segundo Godlee et al. (2011), o estudo de Wakefield et al. (1998) havia sido "encomendado" por um advogado, Richard Barr, com a intenção de aumentar processos contra indústrias farmacêuticas que fabricavam vacinas.
} 
argumentos e razões da não vacinação em ambos os momentos: a vacina pode gerar doença; a vacina é composta por um cocktail de substâncias químicas que podem provocar danos à saúde; a imunidade conferida à vacinação é temporária (ao contrário da imunidade pela própria doença); as vacinas não são eficazes; os órgãos de saúde encobrem e/ou não falam a verdade sobre os riscos e efeitos adversos da vacinação; a política pública de vacinação é autoritária, viola os direitos de escolha individual sobre o que é melhor para sua saúde; e as outras medidas de saúde envolvendo estilo de vida como alimentação, sono, etc. são mais importantes que a vacinação (Poland; Jacobson, 200; Wolfe; Sharp, 2002).

Diante de reações e respostas sociais como redução da adesão às vacinas, aumento da não-vacinação ou dos movimentos anti-vacinação, houve um interesse crescente na comunidade científica em compreender tais posturas e o fenômeno da rejeição à vacina. Muitos deles utilizaram uma abordagem qualitativa, explorando a opinião, as atitudes e crenças de pais em relação à (não) vacinação de seus filhos. A maioria desses estudos foram realizados em países desenvolvidos (EUA, Europa ocidental, Japão e Austrália) e tiveram como participantes de pesquisa a mulher-mãe. Isto pode ser exemplificado pela revisão sistemática, realizada por Mills et al. (2005), de estudos qualitativos sobre a opinião dos pais sobre vacinação que incluiu quinze trabalhos (oito por meio de entrevista em profundidade; cinco grupos focal e dois incluindo ambas abordagens). Foram excluídos da revisão os estudos realizados em países em desenvolvimento (contemplando apenas os EUA, Inglaterra, Canadá e Austrália). A maioria dos estudos (11 em 15) utilizou apenas as mães como interlocutores; e mesmo os que incluíram ambos os pais (4 em 15), a perspectiva de gênero sobre as crenças e tomadas de decisão sobre a imunização do filho não foi explorada.

Neste recorte, um estudo avaliou mães no pós-parto imediato e três a seis meses após, em Yale-New Haven Hospital nos EUA. Conforme a ação e atitude das mães perante a imunização de seus filhos, elas foram classificadas em mães vacinadoras e não-vacinadoras. As mães vacinadoras foram subdivididas em "aceitantes" (as que aceitavam e não questionavam a vacinação) e em "hesitantes" (aquelas que vacinavam, mas tinham preocupações sobre a vacinação). Já as não-vacinadoras foram subdivididas em "vacinadores tardios" (definidas pelos autores como as que propositadamente 
retardavam a vacinação ou selecionavam apenas algumas vacinas para seus filhos) e, por fim, as que rejeitaram "rejecters" (para aquelas que não deram as vacinas para seus filhos). Estes subgrupos mostraram atitudes diversas frente à influência do pediatra tradicional e à busca de informações sobre as vacinas: mães vacinadoras "aceitantes" acreditaram fielmente no pediatra convencional e tiveram menos conhecimento sobre a vacinação infantil; as "vacinadoras tardias" tiveram uma postura mais questionadora sobre a vacinação, buscando também outras fontes de informação além do pediatra; e as "rejecters" buscaram profissionais da medicina não convencional e demais fontes como livros, sites, entre outros (Benin et al., 2006).

Nos países em desenvolvimento, principalmente nos que apresentam cobertura vacinal abaixo da esperada ou que ainda apresentam epidemias de doenças preveníveis por vacinas, como países da África e do sudeste Asiático ${ }^{8}$, destacam-se estudos que fazem uso do método CAP (conhecimento, atitudes e práticas) - KAP study. Os estudos CAP foram e são ainda estimulados pela OMS, para responder aspectos pontuais ou objetivos como a baixa cobertura vacinal, a aceitação ou não da vacinação e a resposta à implementação de um programa vacinal (WHO, 2011).

Os estudos CAP surgiram na década de 1950 no âmbito das pesquisas das Ciências Sociais em Saúde sobre a temática de planejamento familiar em países em desenvolvimento. Eles visam identificar o comportamento de determinada população

\footnotetext{
${ }^{8}$ Alguns exemplos de estudos com o método CAP na temática vacina/vacinação:

Roodpeyma S, Kamali Z, Babai R, Tajik Z. Mothers and vaccination: knowledge, attitudes, and practice in Iran. Journal of Pediatric Infectious Disease. 2007; 2: 29-34.

Phouphenghack K, Kamsrichan W, Vorakitpokatorn S. Knowledge and perception of mothers abaout immunization os children under 3 years of age in the Saythany District, Vientiane, Lao. Journal of Public Health and Development. 2007; 5 (3): 107-116.

WHO. Regional office for Africa. Final Report: 2nd African Reginal Conference on Immunization (ARCI). Ouagadougou, Burkina Faso. 2010.

Bofarraj MAM. Knowledge, attitude and practices of mathers regarding immunization of infants and preschool children at Al-Beida City, Lybia 2008. Egypt J Pediatr Allergy Immunol. 2011; 9 (1): 29-34.
}

Deressa W, Ali A, Enquoselassie F. Development of a questionnaire on knowledge, attitude and practice abaout immunization among Iraqi parents. Journal of Public Health. 2011; 19 (6): 497-503.

Hamid S, Andrabi SAH, Fazli A, Jabeen R. Immunization of children in a rural area of North Kashmir, India: a KAP study. Online Journal of Health and Allied Sciences. 2012; 11 (1).

Al-Lela OQB, Bahari MB, Al-Abbassi MG, Salih MRM, Basher AY. Iraqi parents' views of barriers to childhood immunization. Eastern Mediterranean Heath Journal. 2013; 19 (3): 295-297.

Chikandiwa A, Van Wyk BE. Knowledge and awareness of human papillomavirus and intention with regard to human papillomavirus vaccine uptake by female tertiary students in the Eastern Cape province. South Afr Epidemiol Infect. 2013; 28 (4): 215-20. 
focando o conhecimento, atitudes e práticas específicas a determinado objeto de estudo ou em resposta a alguma intervenção. Trata-se de um método qualitativo focado, de ordem descritiva, com finalidade prática de avaliação para intervenção, com bom custobenefício, porém, apresenta limitações quanto à validade dos seus dados com a prática, dificuldade de padronização, e ao risco de compreender o objeto de estudo mais sob a ótica individual e menos social etc. (Vandamme, 2009).

No Brasil, pelo contexto exitoso do PNI, predominam estudos com outros objetivos e recortes metodológicos como os de custo-efetividade, de avaliação da cobertura vacinal, seja por inquérito domiciliar (Moraes et al., 2000, 2003; Moraes; Ribeiro, 2008), ou usando dados de produção e análise da cobertura vacinal em dias de campanha do PNI, ou ainda trabalhos que avaliam a oportunidade perdida de vacinação (OPV) (Barbieri et al., 2013). As concepções dos pais acerca da imunização do filho e a compreensão em profundidade da tendência à queda da cobertura vacinal em especial na camada média urbana de alta escolaridade (Barata et al., 2012) ainda não são conhecidas.

O breve resgate sócio histórico das práticas de vacinação e dos movimentos antivacinação, sobretudo da Europa Ocidental e da América do Norte, reforça que a vacinação é um fenômeno complexo no âmbito das ciências biológicas e sociais, muitas vezes simplificado em correntes triunfalistas a favor e negativas contra (Moulin, 2003). A complexidade da imunização se manifesta pelos contrastes e ambiguidades como: paternalismo e autonomia na saúde; interesse coletivo/sanitarista e individual; obrigatoriedade e direito à liberdade de escolha sobre o próprio corpo e saúde; visão médica/científica e cultural e de crença; universalidade e singularidade (Moulin, 2003; Pinto, 2004).

Ciente dessa complexidade, este estudo vai procurar ir além da maioria dos encontrados na literatura, que implícita ou explicitamente costumam "atribuir as resistências, as recusas e reticências em relação à vacinação ao invencível atraso dos homens" (Moulin, 2003: 500), um "anacronismo na era do progresso" (Moulin, 2003: 503) ou "um obstáculo a ser contornado mais do que entendido" (Moulin, 2003: 506). Por meio da contribuição da "antropologia das vacinas", e em sintonia com a proposta de Moulin (2003), este estudo - diferentemente dos estudos CAP - buscará fazer uma análise compreensiva da interface entre o processo de escolha pela (não) vacinação dos 
filhos e o cuidado infantil (em saúde) em famílias de alta escolaridade pertencentes às camadas médias de São Paulo-SP, abandonando o conceito de rejeição à vacina (que remete a um fenômeno introjetadamente negativo), e substituindo-o pela compreensão da aceitabilidade da vacina ou da vacinação. O termo aceitabilidade assume que a vacinação não é intangível ou a-histórica, permitindo um confronto e reequilíbrio na relação saúde-sociedade (Moulin, 2003).

Sob a ótica da aceitabilidade, este estudo se justifica perante esse cenário rico, complexo e movediço, que engloba a peculiaridade contextual do programa público de vacinação no Brasil, a tendência de queda da cobertura vacinal em estratos de alta escolaridade e rendimento em grandes centros urbanos do país (a despeito da progressiva melhora da cobertura vacinal nacional), a ausência de estudos nacionais para compreender essa tendência, a recrudescência atual de surtos de sarampo no Brasil e em alguns países desenvolvidos (CVE, 2014) e pelo alerta da Organização Mundial de Saúde do aumento dos casos de poliomielite em países da Ásia Central, Oriente Médio e África Central (CGPNI, 2014), por exemplo.

\subsection{Cuidado e infância: o lugar da criança na família e sua interface com as práticas de saúde}

Fruto dos ideários da modernidade (igualdade, liberdade e racionalidade) e do processo de urbanização, o desenvolvimento da família conjugal moderna no Brasil se intensificou na segunda metade do século XIX, em detrimento das extensas famílias tradicionais patriarcais, fundamentadas na autoridade e autoritarismo do pai, emblemáticas das práticas canavieiras do Nordeste na era colonial (Freyre, 1978; Vaitsman, 1994; Scott P, 2005).

Concebida como o ideal de família burguesa, ela era caracterizada por um casamento oriundo da livre escolha e do amor entre os cônjuges e centrada nos filhos (Singly, 2010). Nessa transição, a criança sai de um lugar periférico, secundário, ou de estorvo (Ariès, 1981), para um de destaque, remodelando toda a família. O homem, "chefe de família", assumiu a função de provedor e protetor da esposa e dos filhos, que ocupa o espaço público por meio do trabalho remunerado - principalmente por 
profissões liberais -, e a mulher, "rainha do lar", foi destinada ao ambiente privado, sendo a responsável pela manutenção da casa, necessidades afetivas da família, cuidado e educação dos filhos. As práticas e os valores eram assim justificados como complementares e funcionais, legitimados pela naturalização da condição biológica segundo o sexo (Vaitsman, 1994).

A partir do século $\mathrm{XX}$, se intensificaram e se difundiram os atributos pessoais como naturais para cada sexo, constructos sociais dos referenciais de gênero tidos como tradicionais: as mulheres como seres frágeis, dóceis, delicadas e mais afetivas e os homens como fortes, robustos e detentores das capacidades intelectuais; os quais invisibilizava o trabalho da mulher e a mantinha dependente do parceiro, perpetuando a desigualdade social de gênero (Vaitsman, 1994).

Entre o século XIX e a segunda metade do século XX, a harmonia entre a valorização da infância e as expectativas das funções de gênero na família conjugal moderna, típicas da camada média urbana burguesa, ocorreu diante da sinergia de movimentos políticos, médicos-higienistas e sociais. A conscientização dos governos da alta mortalidade infantil em diversos países da Europa e da América Latina, incluindo o Brasil, atribuíram à infância o cerne e a projeção do futuro da sociedade e da nação (Nunes, 2011; Freire, 2009). Combater a mortalidade infantil então, passou a fazer parte do "projeto modernizador republicano, que depositava na conservação das crianças, entre outros elementos, esperança para a viabilidade da nação” (Freire, 2008: 154).

No campo da saúde, o movimento médico-higienista e a puericultura se apropriaram da infância e foi por meio da criança que o discurso médico conseguiu penetrar na família através de normas e regras rígidas, propondo uma reformulação familiar (Novaes, 2009; Nunes, 2011). Assim como os higienistas, a puericultura “(...) desenvolve-se em fins do século XIX, na França, e se propõe a normatizar todos os aspectos que dizem respeito à melhor forma de se cuidar de crianças, tendo em vista a obtenção de uma saúde perfeita" (Novaes, 2009: 123). Fica evidente que a principal interlocutora da puericultura é a mãe e não a criança. Respaldada pelo conhecimento validado cientificamente, a puericultura propôs um ideal de maternidade, atribuindo às mulheres a sobrevivência primordial por meio do aleitamento materno e a educação; e de paternidade, realocando o pai de proprietário a provedor, cuja função principal seria de proteção material ao filho (Orlandi, 1985; Costa, 1999; Freire, 2009; Novaes, 2009). 
Dessa forma, a exaltação e culto ao amor materno, assim como as capacidades biológicas de procriação e a amamentação femininas foram valorizadas, agora com preceitos científicos, reforçando o papel da mulher como "devota do lar", esposa e mãe. Nesse processo, cria-se um conjunto de normas que balizaram a configuração de um modelo do "bom pai", e principalmente da "boa mãe", a ser aprendido e seguido, e nele, a mulher passa a ser a responsável pelo bom crescimento e desenvolvimento do filho e culpada em caso de insucesso (Badinter, 1985; Almeida; Novak, 2004).

No âmbito social, destaca-se o movimento feminista maternalista, que associava a maternidade com os preceitos médico-científicos e com o ideário da mulher moderna. Por meio do enaltecimento da maternidade como função social e política, validada pela ciência numa aliança com os discursos médicos, algumas mulheres, sobretudo das camadas urbanas de maior nível socioeconômico, viam uma possibilidade de valorização social e redefinição das relações de poder com seu marido no ambiente doméstico (Freire, 2008, 2009).

O aprofundamento do processo de modernização da sociedade, que emergiu no pós-guerra por meio dos avanços da industrialização e urbanização, propiciou uma maior inserção da mulher no mercado de trabalho; disseminação de creches e babás para cuidarem dos filhos na ausência da mãe; tendência de famílias menores com queda da taxa de natalidade; possibilidade de controle e planejamento da prole com as práticas de contracepção e, mais recentemente, de concepção e maior acesso, principalmente das mulheres da classe média, ao ensino superior, em carreiras tradicionalmente masculinas (Vaitsman, 1994; Scavone, 2001; Scott P, 2005; Guzmán, 2008). Segundo Scavone (2001), é na segunda metade do século XX que a maternidade passa a ser fruto de uma escolha (tanto no número, quanto no momento ou na decisão de ter ou não filhos), sendo este um fenômeno moderno e contemporâneo. A inserção da mulher no mercado de trabalho culmina na conciliação - por vezes conflituosa - da vida profissional, com o exercício da maternagem e as atividades domésticas.

Tais mudanças na sociedade e nas possibilidades de diversas feminilidades advindas em parte pelas proposições e lutas do movimento feminista culminam na crise do padrão dominante da família conjugal moderna, característico das camadas médias urbanas. Segundo Vaitsman (1994: 17), “(...) assistiu-se a um movimento não de modernização da família, mas sim de crise e transformação da típica família moderna", 
sendo substituída por um universo em que coexistem práticas e valores antigos, com uma gama plural e flexível de possibilidades, conteúdos e formas.

No âmbito dos segmentos da camada média urbana, predominou-se na década de 1950 e nas duas décadas seguintes, um padrão tradicional e hierárquico, em que se valorizava a ordem; a diferença intrínseca do gênero e seu poder (em que o homem tinha privilégio pelo trabalho fora e por ser o provedor financeiro); a relação de pais e filhos fundada na disciplina e onde a identidade era fundada na posição (seja pela função, gênero, sexo ou idade), resquícios da família conjugal moderna. Já a partir da década de 1980, predominou outro padrão com uma prerrogativa de maior igualdade entre os gêneros nas relações conjugais e também nas relações parenterais, de pais e filhos; em que os sujeitos, apesar da diferença de gêneros - que implica em desigualdades de oportunidade e de poder nas relações - são iguais como indivíduos e, assim, a identidade está fundada na possibilidade de escolhas, no comportamento, linguagem, moda, estilo etc. (Figueira, 1987; Singly, 2010).

Na família com premissa igualitária, diluem-se as atribuições de gênero e geração, e sobressai o individualismo. Nesse processo, "O sujeito é, então, a parte mais importante da dimensão invisível da mudança social (...)" (Figueira, 1987: 14). Esta transformação da família de camada média urbana brasileira, porém, não é linear e apresenta conflitos, pelo seu ritmo acelerado, a convivência do antigo com o novo e a dissintonia com as mudanças da subjetividade; gerando angústia e mal estar aos sujeitos (Figueira, 1987; Vaitsman, 1994).

O sinergismo entre a acentuada entrada da mulher no mercado de trabalho, com o questionamento feminino das relações de gênero na família e o ideário de maior igualdade - entre gênero e geração - por parte dos homens e mulheres, contribuíram para a (re)discussão do lugar e dos atributos do pai, conduzindo a uma maior expectativa da presença masculina na vida doméstica que, quando realizada, passa a ser descrita como "paternidade participativa" ou "nova paternidade". Ela se caracteriza por uma maior participação do homem nas atividades domésticas e paternais, estas envolvendo maior vínculo afetivo, mais contato, tempo, dedicação; maior presença no cuidado e na educação com os filhos (Quadros, 2006). Estudos recentes sobre a paternidade visaram alcançar a dimensão simbólica de ser pai, na perspectiva do homem. Foi evidenciado que a paternidade tornou-se fundamental na constituição da 
identidade masculina ocidental atual (Quadros, 2006), porém, Costa (2002) salientou que a valorização e incorporação da paternidade na masculinidade ocorreram principalmente nos homens casados, heterossexuais e monogâmicos.

Alguns estudos sobre nova paternidade no Brasil circunscritos nas camadas populares revelaram a permanência de valores tradicionais masculinos, relacionando a paternagem ao pai provedor; a vivência da paternidade como um atributo de ordem mais moral, de responsabilidade, com preocupações de bem estar, subsistência e proteção maior do que a dimensão afetivo-emocional; e que o laço de paternidade é mais diretamente influenciado pela relação com sua parceira e pela experiência pessoal como filho, do que com o vínculo direto a sua criança (Costa, 2002; Bustamante; Trad, 2005; Freitas et al., 2009).

Isso denota que, para esses homens, os aspectos subjetivos relacionados com o amor, carinho e afeto não são $a$ priori associados ao significado de pai. Sob esse ponto de vista, o modelo de pai provedor é o modelo do bom pai, imagem esperada socialmente pelo homem. (Freitas et al., 2009: 88).

Já no contexto das famílias de camadas médias urbanas, estudos evidenciam algumas rupturas com a paternagem alicerçada pelas identidades masculinas tradicionais de protetor e provedor; revelada a maior presença paterna na vida doméstica e maior envolvimento no âmbito afetivo. Apesar de uma maior participação nos afazeres domésticos, no cuidado e na educação ao filho e um maior vínculo afetivo paifilho, Quadros (2006), ao estudar homens de camada média urbana, identificou uma preferência desses pais às atividades lúdicas e educativas, reforçando que a proximidade com o filho era decorrente de funções de cunho emocional e intelectual. Eles também preferiam atividades de higiene e alimentação do filho frente às atividades domésticas da casa, muito embora fosse a mulher que desempenhasse mais ambas as funções. A autora localiza um grande norteador de desigualdade social de gênero, em que o homem pode exercer o poder de escolha das atividades que lhe dão mais prazer ou que lhe agradam mais, justificando a habilidade e/ou competência da esposa. Os pais mais participativos foram encontrados nos casais cujas negociações e ponderações eram frequentes, indicando que a relação conjugal mais equânime balizava uma corresponsabilização maior na relação pai-filho (Quadros, 2006). 
O envolvimento dos pais de forma mais afetiva com seus filhos mostrou-se influenciado pela experiência pessoal deles com seus respectivos pais. A importância do âmbito geracional fica evidente na fala de Badinter (1993: 172): “A maioria [dos homens] se diz em ruptura com o modelo de sua infância e não quer, por nada, reproduzir o comportamento do pai, considerado 'frio e distante'. Eles almejam 'reparar' sua própria infância". Isso originou algo sem precedente na história, a construção de um novo referencial de paternidade, aparentemente destituída de modelos, ou melhor, a busca de uma identidade num "terreno desconhecido" (Sutter; Bucher-Maluschke, 2008; Velásquez; Campos, 2008).

Alguns autores avançaram nos estudos e reflexões acerca da nova paternidade, e encontraram mais um caráter de uma ajuda à mulher-mãe, que uma real mudança no elo pai-filho num ideal de igualdade nos afazeres domésticos: "Los varones califican su trabajo en el hogar como 'ayuda a la esposa', es decir, como si no fuese parte de su responsabilidade (...)" (Guzmán, 2008: s/n). O caráter de ajuda e o distanciamento dessas atribuições tidas como "femininas", mostram a permanência de valores e práticas da família conjugal moderna tradicional, e a preponderância da responsabilização e culpabilização da mulher nos cuidados infantis (Guzmán, 2008; Seabra, 2009).

A complexidade e os paradoxos envolvendo a nova paternidade são refletidos e reproduzidos pela imagem do novo pai pela mídia (Santos, 2005). A autora, ao analisar três revistas com foco na parentalidade (Pais e Filhos, Crescer em Família e Meu Nenê em Família), identificou que a maioria dos artigos são dirigidos à mãe; nas poucas imagens dos pais com as crianças, se privilegia fotos dos pais brincando, passeando, jogando ou acariciando seus filhos, em detrimento ao trabalho doméstico. Nos artigos que focam o que fazer com os filhos no término da licença maternidade, o pai não é citado (Santos, 2005).

Por fim, para polemizar, a nova paternidade é criticada por alguns pediatras franceses, que reforçam o papel primordial e insubstituível da mulher como mãe, e assim, a paternidade mais participativa aparece como potencial ameaça desse lugar tradicionalmente feminino. Para eles, o melhor para a criança não é ter uma "duplicata da mãe”.

O sonho de um bebê não é ter duas mães, mas o de se aconchegar nos braços de sua mãe e sentir o pai cercar a ambos com sua presença 
protetora. É preciso parar de querer a qualquer preço converter os pais em pais maternais. Essa tendência atual é inteiramente ridícula e despropositada. O papel do pai é proteger a mãe, valorizá-la como mãe e como mulher. É preciso que cada um tenha o seu lugar. Para a criança o melhor dos papais é aquele que ama e protege... a mamãe! (Antier ${ }^{9}$ apud Badinter, 2011: 124).

Diante da literatura científica sobre paternidade, é pouco conhecido o lugar dos homens-pais em relação à vacinação de seus filhos, assim como suas concepções sobre as vacinas. Os estudos referentes ao tema vacinação infantil foram realizados em sua grande maioria por meio dos depoimentos das mães (Benin et al., 2006; Mills et al., 2005).

Isso não é exclusivo do campo das imunizações; na literatura científica, o cuidado mostrou-se tão atrelado no imaginário social como atribuição feminina que Gutierrez e Minayo (2010), ao levantar a produção acadêmica sobre cuidado em saúde no âmbito da família, encontraram na maioria dos estudos, independente da metodologia, o interlocutor constituído pela mulher, reforçando "tendências históricas e sociais de reproduzir a figura feminina como a principal responsável pelo cuidado da saúde no lar" (Gutierrez; Minayo, 2010: 1500). Vale ressaltar que esta tendência parte tanto dos pesquisadores - que inviabilizam a possibilidade do olhar da família e do cuidado em saúde pela ótica do homem - quanto das próprias mulheres que "se autodefinem como cuidadoras, vendo-se na posição de responsabilidade pelos cuidados da família" (Gutierrez; Minayo, 2010: 1505).

Diante desse cenário multifacetado, que inclui a valorização da infância, transformações socioculturais da família conjugal moderna, a apropriação médica da infância, o advento da nova paternidade e a tendência científica e sociocultural que tende a invisibilizar o homem como interlocutor do cuidado em saúde da criança, este estudo optou por privilegiar o casal, dando voz ao homem em igual peso que a mulher, na compreensão da interface (não) vacinação e cuidado em saúde infantil em famílias de camadas médias e alta escolaridade de São Paulo-SP.

Além disso, as camadas médias urbanas revelaram especificidades quanto ao padrão sociocultural, com a valorização da biografia, da individualidade e da autonomia dos sujeitos, e conforma expectativas sociais que tendem a ser reproduzidas por outros

\footnotetext{
${ }^{9}$ Antier E. Attendre mon enfant aujourd'hui, 1999: 119.
} 
grupos da sociedade (Velho, 1987, 1994). Diante disso, este estudo buscou compreender o processo de vacinar ou não os filhos por meio do aprofundamento de como o cuidado em saúde e vacinação na criança se estabeleceram na dinâmica dessas famílias e sua relação com as práticas de saúde e imunização vigentes no país na atualidade.

Com base nesse contexto, foram elaboradas as seguintes questões norteadoras dessa investigação:

- Como se conformou o processo de (não) vacinação nos filhos em casais de famílias de camadas médias e alta escolaridade de São Paulo?

- Como ocorre a interface entre a escolha pela (não) vacinação dos filhos e o cuidado infantil nessas famílias?

- Quais são as concepções sobre a vacinação infantil de pais e mães que vacinaram, selecionaram ou não vacinaram os filhos, nesse segmento social?

- Como a interface (não) vacinação e cuidado infantil se estabelecem na dinâmica familiar, nas relações de gênero e geração?

- De que forma essas dimensões sobre vacinação e cuidado infantil dizem respeito aos padrões socioculturais atualmente em curso na sociedade? 


\section{OBJETIVOS}

\section{Objetivo geral}

Compreender o processo de (não) vacinação nos filhos e sua interface com o cuidado infantil por casais de famílias de camadas médias e alta escolaridade de São Paulo.

\section{Objetivos específicos}

- Identificar as concepções de pais e mães de camada média e alta escolaridade de São Paulo-SP acerca da vacinação de seus filhos.

- Identificar as similitudes e as diferenças da concepção de cuidado em relação à imunização infantil entre os núcleos familiares que vacinaram, selecionaram ou não vacinaram os filhos, nesse segmento social.

- Compreender como a interface (não) vacinação e cuidado infantil se estabelece na dinâmica familiar, no tocante às relações conjugais, parentais e de geração.

- Apreender, a partir da percepção dos casais, as influências e o papel do pediatra na tomada de decisão em (não) vacinar os filhos.

- Compreender como valores e práticas sobre a (não) vacinação e o cuidado infantil em famílias de camada média paulistana se vinculam a processos mais amplos de transformação social. 


\section{REFERENCIAIS TEÓRICOS}

Nesse capítulo será apresentada uma síntese dos referenciais elegidos, cuidado, família e gênero, cuja elaboração priorizou a articulação de seus conceitos, reunidos de forma concisa, com o objeto de estudo. A escolha desses referenciais foi balizada pela intenção de nortear as diferentes esferas relacionais sobre a (não) vacinação e cuidado infantil.

O principal referencial teórico desse estudo é a perspectiva do cuidado, no intuito de orientar as dimensões relacionais, tanto no tocante às relações interpessoais no interior da família (conjugais, parentais e de geração), quanto às relações entre indivíduos / família com o seu meio social mais próximo e as práticas de vacinação e de saúde infantis.

Além de orientar a trama inter-relacional encontrada no empírico, a escolha do referencial teórico procurou contemplar o aprofundamento dessas relações diante das especificidades socioculturais da população escolhida. Partiu-se do pressuposto que características marcantes das camadas médias urbanas podem enriquecer as discussões acerca das práticas e valores dessas famílias, sinergicamente à dimensão do cuidado; e mais que isso, permite fazer a ponte dessas qualidades com transformações sociais mais amplas, oriundas das sociedades complexas contemporâneas.

Uma vez que este estudo propôs inovar colocando também como interlocutor do cuidado em saúde e da (não) vacinação infantil o homem-pai, neste capítulo também será abordado o referencial de gênero escolhido para guiar as reflexões acerca das relações de conjugalidade e parentalidade encontradas no empírico que mediaram o cuidado à criança na intimidade dessas famílias.

\subsection{A perspectiva do cuidado}

A perspectiva do cuidado que norteará o olhar sobre o empírico será fundamentada pelo conceito usado por José Ricardo de Carvalho Mesquita Ayres, que 
faz uma releitura do termo a partir da categoria ontológica heideggeriana, trazendo-o para o campo da saúde.

Heidegger, em sua obra Ser e Tempo, aponta o cuidado (Sorge) como o substrato pelo e sobre o qual se concebe e sustenta a existência humana: o modo de ser do humano, a partir do ser-no-mundo (ser-aí ou Dasein). A dimensão do cuidado ocorre no processo do ser humano compreender-se a si mesmo e ao mundo, por meio do contato com outros entes, o ser-com, balizando as formas de ação e interação de caráter existencial. Assim, os atos de cuidar e ser cuidado são, em primeira instância, a identificação de estarmos vivos (Ayres, 2007; Carrilho, 2010).

Partindo desta concepção e da alegoria de Higino utilizada por Heidegger, Ayres (2007), destaca características importantes acerca do cuidado: 1) o caráter movente, onde o cuidado se constrói na ação de se movimentar no e pelo mundo; 2) a interação, em que o cuidado e a identidade se estabelecem por meio do ser-com, na alteridade, ou seja, na presença com o outro; 3) a plasticidade, que faz alusão à capacidade de transformação e contínua (re)criação do cuidado; 4) a ideia de projeto, em que o cuidado se instala na competência de projetar-se no mundo e construir projetos; 5) a temporalidade; 6) a compreensão hermenêutica do cuidado, ao invés do reducionismo interpretativo de causa-efeito e, por fim; 7) a responsabilidade, em que o cuidado está vinculado à responsabilização para e por si. (Ayres, 2004).

No âmbito das práticas e tecnociências da saúde, vive-se esta questão de forma conflituosa, com a coexistência do progresso da medicina contemporânea, sob a ótica biomédica e apoiada no acelerado desenvolvimento científico e tecnológico, que trouxe importantes e já conhecidos avanços na saúde (aumento da precisão e rapidez do diagnóstico, intervenções terapêuticas mais eficazes, melhora da qualidade de vida e da sobrevida da população, entre outros progressos); com a eclosão de uma "crise de legitimidade" das práticas de saúde atuais, tanto individuais quanto coletivas; em que o modelo normativo vem mostrando descontentamento, limitações e distanciamento dos contextos e necessidades de pessoas e populações (Schraiber, 2008; Ayres, 2003, 2004).

Em resposta a esta crise nas práticas de saúde e dos seus consequentes desafios, surgiram reflexões que levam em consideração transformações sociais, políticas, econômicas e culturais da sociedade (e, por conseguinte na família) e buscam alcançar com profundidade as dimensões envolvidas no processo saúde-doença e a aproximação 
de profissionais e gestores com os indivíduos e grupos. Dentre elas encontra-se a perspectiva do cuidado em saúde explorado por Ayres, conceito usado como categoria reconstrutiva, de caráter reflexivo crítico, para proposições e transformações das práticas em saúde.

Esta perspectiva do cuidado em saúde apoia-se na mudança do enfoque de tratar, curar e controlar para o de cuidar. Propõe ampliar o horizonte normativo, visando ir além de enxergar os indivíduos e/ou grupos como objeto de ação, de "corrigir" distúrbios morfo-funcionais e de buscar a regularidade da doença. Ancorado no caráter relacional entre o cuidador e a pessoa cuidada, mediante os processos e contextos de intersubjetividade, objetiva uma maior compreensão da dimensão saúde-doençaintervenção que ocorre no encontro entre os sujeitos. A humanização por meio deste conceito de cuidado pode se legitimar - pela validade afetiva e sociocultural - com a aproximação, não só dos sujeitos envolvidos, mas também dos êxitos das tecnociências biomédicas com a sabedoria e o sucesso práticos, cuja ponte se fundaria no que faz sentido aos indivíduos e às coletividades, seus projetos de felicidade (Ayres, 2001, 2003, 2004, 2007).

Para compreender o que o autor chama de projeto de felicidade, o termo projeto remete à concepção ontológica de Heidegger de cuidado, descrita acima, que ao mesmo tempo abarca uma temporalidade, contexto em que está inserida esta existência, e uma característica atemporal, no potencial de constante reconstrução destes projetos. Já a felicidade, pelo autor, refere-se à associação de uma experiência vivida com valores positivos, de cunho tanto individual quanto sociocultural (Ayres, 2003, 2004, 2007).

No campo da saúde, então, Ayres define “(...) Cuidado como designação de uma atenção à saúde imediatamente interessada no sentido existencial da experiência do adoecimento, físico ou mental, e, por conseguinte, também das práticas de promoção, proteção ou recuperação da saúde" (Ayres, 2004: 22, grifos do autor). No tocante às coletividades, a noção de cuidado pode ser por meio da aproximação dialógica entre os sujeitos profissionais/gestores e os diferentes sujeitos coletivos - aqui exemplificados pelos pais e mães da camada média urbana de alta escolaridade - superando "as barreiras linguísticas que o jargão técnico interpõe a uma autêntica interação entre profissionais e população." (Ayres, 2001: 70). 
Por fim, o conceito de cuidado e seus diversos aspectos nortearão a dimensão relacional e dialógica do encontro com o outro. Primeiro, metodologicamente, por meio da aproximação com casais de classe média urbana, dando voz às duas populações com pouco espaço de interlocução, os homens em geral sobre o cuidado em saúde do filho, e os casais que não vacinam os filhos (um grupo invisibilizado e ao mesmo tempo criticado e temido por muitos gestores e profissionais da saúde biomédicos). Segundo, no âmbito analítico, em que o conceito de cuidado orientará as relações interpessoais deste estudo, tanto no contexto da intimidade das interações familiares (na conjugalidade, parentalidade e nas relações de geração); quanto perante seu meio social próximo e as práticas em saúde, em especial, as de imunização.

\subsection{O universo das camadas médias urbanas}

O recorte deste estudo privilegiou famílias de alta escolaridade pertencentes à camada média urbana de São Paulo-SP. O trabalho do antropólogo Gilberto Velho foi escolhido para nortear o olhar acerca das peculiaridades socioculturais dessa população e sua relação com a sociedade mais ampla. Esta escolha baseou-se não só pela aproximação de seus estudos direcionados à mesma população e universo sociocultural aqui abordado, mas também pela sincronia teórico-metodológica. Este estudo, assim como os trabalhos de Gilberto Velho (1994), apoia-se na antropologia interpretativa de Geertz (descrita a seguir), na percepção de indivíduo em sua singularidade, apreendido como sujeitos de uma ação social, esta fundada por uma rede de significados: "o homem é um animal amarrado a teias de significado que ele mesmo teceu, assumo a cultura como sendo essas teias e a sua análise" (Geertz, 2008: 4).

A problemática entre a perspectiva de olhar o sujeito como agente de sua experiência/vivência individual e a de encará-lo com a mediação do contexto e da dimensão sociocultural em que ele está inserido é trabalhada por Velho $(1987,1994)$ com as noções de projeto e campo de possibilidades, respectivamente, ambas concepções oriundas das sociedades complexas contemporâneas.

Assim, evitando um voluntarismo individualista agonístico ou um determinismo sociocultural rígido, as noções de projeto e campo de possibilidades podem ajudar a análise de trajetórias e biografias 
enquanto expressão de um quadro sócio-histórico, sem esvaziá-las arbitrariamente de suas peculiaridades e singularidades. (Velho, 1994:40, grifos do autor).

A heterogeneidade cultural e a coexistência - conflituosa ou não - de uma pluralidade de experiências, costumes e instituições nas sociedades complexas contemporâneas, sobretudo nas metrópoles, conduz, na visão de Velho (1987), a duas principais possibilidades. A primeira - e mais característica da modernidade e pósmodernidade - à valorização da individualidade, ou melhor, o enaltecimento da vida psicológica individual. A segunda, na qual o agente empírico, diante da multiplicidade de opções, se identifica com um destes possíveis mundos e assume estereótipos como "boa mãe", "empresário", "atleta", "vegetariano" etc. O autor frisa que estas possibilidades não são excludentes, e podem conviver em maior ou menor grau, conforme a fase da vida, os atributos ou as ações (Velho, 1987).

O autor defende que a primeira alternativa, a valorização da individualidade, é fruto da fragmentação, diversidade e diferenciação de ações e atributos individuais. É na necessidade de mover-se por estes mundos e dar sentido e coerência existencial à sua vivência cotidiana, no processo de individualização da sociedade, dando lugar e valor ao indivíduo-sujeito, que surge a noção de projeto, pois é o indivíduo-sujeito que constrói projetos.

Quanto mais exposto estiver o ator a experiências diversificadas, quanto mais tiver de dar conta de ethos e visões de mundo contrastantes, quanto menos fechada for sua rede de relações ao nível do seu cotidiano, mais marcada será a sua autopercepção de individualidade singular. Por sua vez, a essa consciência da individualidade - fabricada dentro de uma experiência cultural específica - corresponderá uma maior elaboração de um projeto. (Velho, 1987:32, grifos do autor).

Velho $(1987,1994)$ trabalha a ideia de projeto individual, em cujas escolhas e opções (a dimensão mais consciente da ação social) são (re)construídas no decorrer da vida do sujeito, ancoradas na sua avaliação e definição de realidade.

Esse autor problematiza que o projeto não é puramente individual, internalizado, subjetivo. Ele só pode ser constituído através de um campo de possibilidades, contextualizado histórico culturalmente. Na pluralidade de estímulos característicos das sociedades complexas contemporâneas é que surge um campo de possibilidades situado especial, temporal e culturalmente; por meio do qual serão cruzadas e percorridas 
diversas trajetórias individuais e grupais; e formulados e implementados os projetos (Velho, 1987, 1994).

Ademais, a condição básica para um projeto existir é ele ser expresso, captado e reconhecido pelo outro: é na comunicação, por meio da linguagem, que o projeto tem vida, faz sentido ou é rejeitado. O autor, sem desindividualizar o sujeito do projeto, reconhece a importância da dimensão cultural na experiência individual: "Mesmo que o ator viva a sua experiência como única, ele de alguma forma reconhece-se nos outros através de semelhanças e coincidências" (Velho, 1987: 28). Os projetos individuais podem se tornar projetos sociais, se compartilhados por um grupo de indivíduos com interesses comuns, cuja expressão se dá principalmente por meio da dimensão simbólica. Porém, os projetos coletivos nunca são vividos e experimentados da mesma maneira ou de forma homogênea pelos que os compartilham ou rejeitam.

Gilberto Velho (1987) ressaltou que é, sobretudo no universo das camadas médias urbanas e escolarizadas, mais expostas às ideologias de modernização, que aparecem com maior vigor a valorização e a incorporação da trajetória de vida, da biografia e da experiência pessoal. A visão de mundo e o estilo de vida do sujeito de forma individual são além de um valor, uma referência básica. Ademais, as experiências individuais e as emoções conformam preocupações centrais nas vidas das pessoas. A camada média urbana intelectualizada e psicologizada valoriza a própria biografia e sua trajetória de vida dando ênfase ao desempenho individual. Nesta população, o indivíduo é socialmente valorizado, significativo, único, o protagonista de escolhas e realização de projetos. Dá-se, assim, importância à autonomia dos sujeitos, à igualdade e liberdade de escolha, à singularidade e à busca de sentido ao indivíduo. Para o autor, é nesta população que se encontra com maior força e frequência, discursos e práticas de crítica e inovação (Velho, 1987, 1994).

Velho, por meio dos estudos com famílias de camadas médias em CopacabanaRJ, identifica que o processo de nuclearização da família teve um papel importante na individualização e valorização dos projetos individuais. O estreitamento dos contatos com outros familiares, vizinhos ou outros laços sociais faz a família conjugal corporificar, enfatizar e expressar os projetos individuais (Velho, 1987).

Por fim, as valorizações do sujeito, da biografia, da pluralidade de escolhas, do ideal de igualdade característicos das camadas médias urbanas escolarizadas e as noções 
de Gilberto Velho de projeto e de campo de possibilidades nortearão a análise dos depoimentos dos pais e mães de alta escolaridade pertencentes às camadas médias de São Paulo frente às escolhas sobre a vacinação de seus filhos.

\subsection{A perspectiva de gênero nos estudos de família e saúde}

O emprego de gênero como categoria analítica nos estudos do campo da saúdedoença-intervenção proporcionou uma mudança paradigmática, com a transição de investigações sobre as diferenças entre homens e mulheres calcadas no determinismo biológico, para a da apreensão das relações sociais do sexo, mediadas pelo poder e desigualdade, e na ênfase da compreensão das diversidades ou semelhanças entre homens e mulheres como constructos (re)produzidos sociocultural e historicamente (Aquino, 2006).

Nessa trajetória, entre o século XIX até meados do século XX, prevaleceu na literatura biomédica a perspectiva da saúde materno-infantil, com o foco no âmbito reprodutivo da mulher e na saúde da criança, visando queda da mortalidade infantil (Aquino, 2006; Nunes, 2011). A partir de 1970, com a influência do movimento feminista na academia, os estudos passaram a transferir a atenção das funções reprodutivas da mulher - com predomínio sobre as temáticas gestação, parto e aleitamento - para a visibilidade da mortalidade materna a partir de 1980 (ainda com predomínio do enfoque clínico-epidemiológico); e após, com uma maior apropriação da perspectiva de gênero, eles enfatizaram a denúncia à invisibilidade de outros temas vivenciados pelas mulheres como aborto, contracepção, trabalho, violência doméstica, entre outros (Aquino, 2006; Strey; Pulcherio, 2010).

Já nos anos 2000, ampliaram-se em número e diversidade os temas relacionando gênero e saúde, como reprodução assistida, violência, sexualidade, masculinidade e HIV/AIDS. É nesse momento que aumentam estudos sobre paternidade e cuidado à criança (Aquino, 2006). Nesse contexto, a incorporação da perspectiva de gênero nos estudos de família permitiu ampliar e aprimorar as análises acerca das dinâmicas relacionais internas familiares e da dimensão simbólica (valores, normas) (Couto, 2005). A autora reitera a possibilidade de se pensar, na instância familiar, "gênero como 
sistema simbólico que organiza relações de poder, igualdades e desigualdades no público e no privado, no trabalho e na família, e na relação entre os dois" (Couto, 2005: 203).

Inicialmente como objeto de estudo nos campos das Ciências Sociais e da Psicologia (desde 1980), o interesse sobre a paternidade vem ganhando espaço nos últimos anos, com destaque nos estudos que visam alcançar a dimensão simbólica interna na ótica dos próprios pais (Quadros, 2006; Silvia; Piccinini, 2007; Souza; Benetti, 2009).

$\mathrm{Na}$ interface com a saúde, desde os anos 2000, a paternidade apareceu em temáticas que englobaram principalmente o pai adolescente (Meincke, 2009), o pai de filho adotivo (Andrade et al., 2006), o pai na gestação (Piccinini et al., 2004), o pai de filho prematuro (Tronchin; Tsunechiro, 2006) e o pai na amamentação (Pontes et al., 2008), a maioria oriundo das áreas da psicologia, enfermagem, assistência social e nutrição.

A inclusão tanto do homem quanto da mulher como narradores do cuidado e da (não) vacinação infantil no presente estudo permite abrir o leque para a possibilidade de se explorar como essa dimensão se conforma nas relações conjugais e parentais, na perspectiva de gênero. No tocante à parentalidade, importa reconhecer como os fatores relacionados aos valores sociais atribuídos à paternidade e à maternidade, assim como as imposições de conjunturas econômico-sociais, favorecem possíveis (re)configurações e (re)posicionamentos de homens e mulheres na família; enquanto a dimensão da conjugalidade pode ser analisada em termos das negociações e tensões produzidas no cotidiano da relação conjugal a partir de tais fatores e como estes repercutem na relação de cuidado com os filhos.

O referencial de gênero escolhido para orientar as reflexões sobre o objeto de estudo na intimidade familiar foi o proposto pela historiadora Joan Scott. Para a autora, gênero faz referência a um constructo social das relações e distinções entre os sexos, abandonando as premissas do determinismo biológico relacionadas ao sexo. Assim, gênero revela, gera e reproduz, a partir das diferenças entre os sexos - biológicas e físicas - significados, valores, comportamentos e crenças construídos culturalmente (Scott, 1995). Esta categoria é, portanto, “(...) ordenadora de práticas sociais e, como tal, 
condiciona a percepção do mundo e o pensamento. Funciona, assim, como um crivo por meio do qual o mundo é apreendido pelo sujeito." (Couto et al., 2010: 267).

Para Scott (1995), a conjectura primeira de que gênero "é um elemento constitutivo de relações sociais baseadas nas diferenças percebidas entre os sexos" (Scott, 1995: 86), se sustenta por meio das seguintes esferas inter-relacionadas: 1) simbólica, construída culturalmente; 2) normativa expressa na religião, ciência, educação e nas leis, entre outras Instituições, que costumam reforçar o binarismo entre homens e mulheres; 3) conceitual, em que gênero é construído para além do sistema de parentesco, com influência do contexto político-econômico; e 4) de caráter subjetivo (Scott, 1995).

A autora explora três dimensões que concerne à categoria gênero: a sócio histórica, a relacional e a de relações de poder (Scott, 1995; Grossi et al., 1998), explicitada em sua fala em entrevista a seguir:

Quando falo de gênero, quero referir-me ao discurso da diferença dos sexos. Ele não se refere apenas às ideias, mas também às instituições, às estruturas, às práticas quotidianas, como também aos rituais e a tudo que constitui as relações sociais. O discurso é um instrumento de ordenação do mundo, e mesmo não sendo anterior à organização social, ele é inseparável desta. Portanto, o gênero é a organização social da diferença sexual. Ele não reflete a realidade biológica primeira, mas ele constrói o sentido dessa realidade. A diferença sexual não é a causa originária da qual a organização social poderia derivar. Ela é antes uma estrutura social movente, que deve ser analisada nos seus diferentes contextos históricos (Grossi et al., 1998: 115).

Nesta fala, Joan Scott pontua a primeira característica inerente ao gênero: seu caráter "movente", ou seja, uma construção social em constante (re)significação e a necessidade de contextualização. Esta construção é demarcada e condicionada conforme o caráter sócio histórico, convivendo com rupturas e permanências de outros momentos. A autora enfatiza a necessidade e a importância de historicizar gênero, contextualizando sociocultural e historicamente as subjetividades criadas para homens e mulheres; as relações entre eles; as ideias, conceitos, usos e status do corpo e da diferença sexual. Isso é fruto de um posicionamento em oposição à corrente essencialista, que adota as questões relativas às diferenças ligadas ao sexo e ao corpo características biológicas, físicas, de reprodução e de parentalidade - como essência dos 
homens e das mulheres e, portanto constantes, imutáveis e descontextualizadas, fixando a oposição binária e cristalizada de gênero (Scott, 1995; Grossi et al., 1998).

Scott enfatiza que gênero vai além de conotações de cada sexo pelo social. Ele é apreendido pela dimensão relacional: é na interação com o outro que as relações de gênero são definidas e se (re)definem (Scott, 1995). Neste estudo, serão analisados tanto o caráter relacional conjugal, quanto o parental (paternidade e maternidade), na dinâmica familiar dos casais de camada média paulistana acerca do cuidado e da (não) vacinação infantil.

A autora também acrescenta que o gênero é útil para explicar as desigualdades sociais pela dimensão de poder inerente nas relações entre homens e mulheres, e entre pessoas do mesmo sexo, articulando-se com outros referenciais como classe, raça/etnia. Scott teoriza gênero lançando a proposição que "o gênero é a forma primária de dar sentido às relações de poder. Seria melhor dizer: o gênero é o campo primário no interior do qual, ou por meio do qual, o poder é articulado" (Scott, 1995: 88). 


\section{MÉTODO E CAMPO DA PESQUISA}

A produção dos dados empíricos foi conduzida pela abordagem qualitativa, por meio da utilização da técnica de entrevista em profundidade. A escolha desta técnica foi devido a sua potencialidade de captar os valores e os sentidos que os participantes atribuem a eventos de sua experiência pessoal, com a intenção de alcançar a dimensão da subjetividade, já que a fala dos entrevistados é reveladora de sistemas de valores, crenças, normas, sendo significantes mesmo sem a intenção de significar. Ao contemplar os âmbitos das vidas dos sujeitos, seus contextos na família e na sociedade e suas subjetividades, tal técnica possibilita atingir o universo simbólico do cuidado e imunização infantil na população estudada, na perspectiva socioantropológica (Becker, 1992; Fontana; Frey, 2000; Poupart, 2008).

A entrevista em profundidade partiu de um roteiro pré-estabelecido (anexo 1) ${ }^{10}$, mas de caráter aberto, construído intencionalmente por perguntas amplas sobre as vivências do cuidado ao filho e do processo da escolha pela (não) vacinação, em contraponto da proposta da grande maioria dos estudos relacionados ao tema, com pais que não vacinaram seus filhos, em que as perguntas já reposicionam esses participantes num lugar a priori de justificativa, ou que o objetivo maior é compreender as razões da rejeição a essa prática consagrada. Ao invés de construir perguntas que por si atribuem preceitos negativos e predeterminam a não-vacinação como um atraso ou reprocesso do humano, esse estudo buscou dar voz e liberdade à população escolhida sobre a temática do cuidado e vacinação infantil.

$\mathrm{O}$ roteiro, assim, foi o meio norteador para se alcançar narrativas sobre as vivências acerca do desejo de ter filho(s), da gestação, parto, dos cuidados diários ao lactente, cuidados em saúde, do processo da vacinação (ou da não vacinação), a influência para a tomada de decisão em vacinar ou não, os sentimentos oriundos dessas vivências, e depoimentos sobre como o parceiro(a), sob a percepção de cada sujeito da pesquisa, viveu essas experiências. Para os pais que vacinaram ou selecionaram as vacinas dos filhos, também foi explorado como ocorreu a escolha entre o serviço público e o privado e o papel do pediatra nessa escolha. O roteiro foi usado como um

\footnotetext{
${ }^{10} \mathrm{O}$ roteiro e o trabalho de campo foram realizados anteriormente ao projeto maior financiado pelo CNPq.
} 
guia, permitindo total flexibilidade nas ordens das questões e a possibilidade de explorar determinadas reflexões quando fossem oportunas. A ordem do roteiro foi percorrida "respeitando a sequência das questões relatadas no depoimento do entrevistado" (Feliciano, 2010: 35), ou seja, o fio condutor era o relato do sujeito da pesquisa, conciliando direcionamento temático e liberdade de expressão.

No tocante à conformação dos participantes de pesquisa, o recorte do estudo almejou alcançar a maior diversidade de escolhas, situações e sentidos referentes à vacinação infantil no segmento social de camada média e alta escolaridade paulistana. Para tanto, a captação dos casais foi direcionada de acordo com a escolha prévia sobre a vacinação dos filhos, com o intuito de assegurar a presença de casais que não vacinaram ou selecionaram as vacinas dos filhos. Para contemplar a pluralidade almejada, buscouse captar casais que se encaixassem em uma dessas três possibilidades: 1) casais que vacinaram os filhos, definidos por aqueles que imunizaram seus filhos de acordo com as recomendações do PNI (podendo conter ou não outras vacinas não incluídas no calendário básico do PNI vigente à época da entrevista e independente do local onde foram realizadas as vacinas - SUS ou clínica privada); 2) casais que selecionaram as vacinas dos filhos, para os que vacinaram parcialmente ou postergaram as datas das vacinas, estando assim, em desacordo com as recomendações do PNI e 3) casais que não vacinaram seus filhos, aos que não haviam dado qualquer vacina ao filho, até o momento da entrevista.

Essa classificação escolhida foi adaptada de estudos internacionais, como o de Benin et al. (2006). Porém, diferentemente deste estudo, que denominaram as mães como vacinadoras (aceitantes ou hesitantes) e não-vacinadoras (vacinadores tardios ou rejecters), foi optado aqui por denominar os casais como aqueles que vacinaram, selecionaram ou que não vacinaram os filhos no momento da entrevista. Essa decisão foi balizada pela intenção de não rotular ou taxar os participantes do estudo, partindo-se do pressuposto que a escolha de vacinar ou não os filhos não é rígida, e sim, passível de mudanças.

A captação dos participantes foi feita por meio do procedimento de "bola de neve" (Kendall et al., 2008), estratégia que mostrou-se apropriada para a identificação de populações minoritárias, excluídas ou de difícil acesso, como é o caso dos casais que não vacinaram seus filhos. Assim, partindo de um ponto inicial de indicação, cada casal 
entrevistado indicava mais um ou dois casais para participarem do estudo. Em todos os casais, buscou-se contemplar uma diversidade em relação à profissão dos participantes, com o intuito de se alcançar o universo simbólico de pessoas pertencentes à camada média paulistana intelectualizada, com maior riqueza e pluralidade, evitando que as dimensões encontradas no material empírico pudessem ser específicas de uma determinada profissão liberal, por exemplo, assim como o local de residência.

O recorte do estudo privilegiou casais que moravam juntos, com filhos de até cinco anos, residentes em São Paulo-SP. Não foram incluídos casais com outra conformação familiar (como famílias recompostas, monoparentais ou homoparentais), com a intenção de incluir o homem como interlocutor do cuidado em saúde de seus filhos, e evitando complexar o entendimento do cuidado infantil e vacinação nesse segmento sociocultural em decorrência de interferências de outras ordens. A faixa etária dos filhos de zero a cinco anos de idade teve o propósito de aproximar os interlocutores do período de maior concentração de vacinas no calendário básico infantil do PNI (tabela 1) e, assim, no momento em que as decisões sobre as vacinações infantis são mais presentes e frequentes nos casais.

Além disso, no recorte do estudo foi definido que o casal tinha que ter pelo menos nível superior completo e pertencer à camada média de São Paulo-SP. Como ponto de partida, foi usada uma ferramenta de triagem, o Critério de Classificação Econômica Brasil 2011 da Associação Brasileira de Empresas de Pesquisa (ABEP, 2011) ${ }^{11}$. Porém, pela ciência que esse instrumento avalia estratos sociais, ou seja, a agregação de indivíduos de acordo com critérios pré-definidos (Outhwait et al., 1996) e poder de consumo, o que foi considerado foi a identificação dos participantes em pertencer ao conceito mais amplo de classe. Nominada neste estudo como camada média urbana, em correspondência à terminologia usada por Velho (1987, 1994), foi considerada como um "conceito genérico utilizado no estudo da dinâmica do sistema

\footnotetext{
${ }^{11}$ Instrumento que avalia o poder de compra e a escolaridade da família, classificando-os em A1, A2, B1 e B2, C, D e E (ABEP, 2011). Esse estudo considerou apenas casais que se encaixaram nos estratos A1, A2, B1 e B2. De acordo com este critério, nenhum casal foi classificado como A1, nove casais foram classificados como A2, cinco como B1 e dois deles como B2, ressaltando as limitações deste critério: ele "a princípio" avalia o poder de compra/consumo (por meio da aquisição de bens como televisão em cores, radio, máquina de lavar, DVD e geladeira/freezer; número de banheiro na casa; automóvel; contratação de empregada mensalista), mais a escolaridade, considerando a aquisição ou não desses bens apenas como uma questão econômica, não levando em consideração a possibilidade de intermédio de outros âmbitos, como de cunho ideológico (por exemplo, não ter carro ou não contratar uma empregada mensalista por outros princípios que não o poder financeiro).
} 
social" (OUTHWAIT et al., 1996: 93), que designa grupos amplos enfatizando o caráter mais relacional entre os indivíduos, qualificando-os principalmente pela: distribuição

Tabela 1: Calendário básico de vacinação da criança do Ministério da Saúde em 2010*

\begin{tabular}{|c|c|c|c|}
\hline IDADE & VACINAS & DOSE & DOENÇAS EVITADAS \\
\hline \multirow{2}{*}{$\begin{array}{c}\text { Ao } \\
\text { nascer }\end{array}$} & Vacina BCG & $\begin{array}{l}\text { Dose } \\
\text { única }\end{array}$ & Formas graves de tuberculose \\
\hline & Hepatite B & $1^{\mathrm{a}}$ dose & Hepatite B \\
\hline 1 mês & Hepatite B & $2^{\mathrm{a}}$ dose & Hepatite B \\
\hline \multirow{4}{*}{2 meses } & Tetravalente (DPT+Hib) & \multirow{4}{*}{$1^{\mathrm{a}}$ dose } & $\begin{array}{l}\text { Difteria, tétano, coqueluche, meningite e } \\
\text { outras infecções causadas pelo } \\
\text { Haemophilus influenzae tipo B }\end{array}$ \\
\hline & Vacina oral poliomielite (VOP) & & Poliomielite ou paralisia infantil \\
\hline & $\begin{array}{l}\text { Vacina oral de rotavírus humano } \\
\text { (VORH) }\end{array}$ & & Diarreia por rotavírus \\
\hline & $\begin{array}{l}\text { Vacina pneumocócica } 10 \text {-valente } \\
\text { (conjugada) }\end{array}$ & & $\begin{array}{l}\text { Pneumonia, otite, meningite e outras } \\
\text { doenças causadas pelo Streptococcus } \\
\text { pneumoniae }\end{array}$ \\
\hline 3 meses & $\begin{array}{l}\text { Vacina meningocócica } \mathrm{C} \\
\text { (conjugada) }\end{array}$ & $1^{\mathrm{a}}$ dose & $\begin{array}{l}\text { Doença invasiva caudada pela Neisseria } \\
\text { meningitidis tipo C }\end{array}$ \\
\hline \multirow{4}{*}{4 meses } & Tetravalente (DPT+Hib) & \multirow{4}{*}{$2^{\mathrm{a}}$ dose } & $\begin{array}{l}\text { Difteria, tétano, coqueluche, meningite e } \\
\text { outras infecções causadas pelo } \\
\text { Haemophilus influenzae tipo B }\end{array}$ \\
\hline & Vacina oral poliomielite (VOP) & & Poliomielite ou paralisia infantil \\
\hline & $\begin{array}{l}\text { Vacina oral de rotavírus humano } \\
\text { (VORH) }\end{array}$ & & Diarreia por rotavírus \\
\hline & $\begin{array}{l}\text { Vacina pneumocócica 10-valente } \\
\text { (conjugada) }\end{array}$ & & $\begin{array}{l}\text { Pneumonia, otite, meningite e outras } \\
\text { doenças causadas pelo Streptococcus } \\
\text { pneumoniae }\end{array}$ \\
\hline 5 meses & $\begin{array}{l}\text { Vacina meningocócica } \mathrm{C} \\
\text { (conjugada) }\end{array}$ & $2^{\mathrm{a}}$ dose & $\begin{array}{l}\text { Doença invasiva caudada pela Neisseria } \\
\text { meningitidis tipo C }\end{array}$ \\
\hline \multirow{4}{*}{6 meses } & Hepatite B & \multirow{4}{*}{$3^{a}$ dose } & Hepatite B \\
\hline & Tetravalente (DPT+Hib) & & $\begin{array}{l}\text { Difteria, tétano, coqueluche, meningite e } \\
\text { outras infecções causadas pelo } \\
\text { Haemophilus influenzae tipo B }\end{array}$ \\
\hline & Vacina oral poliomielite (VOP) & & Poliomielite ou paralisia infantil \\
\hline & $\begin{array}{l}\text { Vacina pneumocócica } 10 \text {-valente } \\
\text { (conjugada) }\end{array}$ & & $\begin{array}{l}\text { Pneumonia, otite, meningite e outras } \\
\text { doenças causadas pelo Streptococcus } \\
\text { pneumoniae }\end{array}$ \\
\hline & Tríplice viral (SCR ou MMR) & $1^{\mathrm{a}}$ dose & Sarampo, caxumba e rubéola \\
\hline 12 meses & $\begin{array}{l}\text { Vacina pneumocócica } 10 \text {-valente } \\
\text { (conjugada) }\end{array}$ & Reforço & $\begin{array}{l}\text { Pneumonia, otite, meningite e outras } \\
\text { doenças causadas pelo Streptococcus } \\
\text { pneumoniae }\end{array}$ \\
\hline \multirow{3}{*}{15 meses } & Tríplice bacteriana (DPT) & \multirow{3}{*}{$\begin{array}{l}1^{\mathrm{o}} \\
\text { reforço }\end{array}$} & Difteria, tétano e coqueluche \\
\hline & Vacina oral poliomielite (VOP) & & Poliomielite ou paralisia infantil \\
\hline & $\begin{array}{l}\text { Vacina meningocócica } \mathrm{C} \\
\text { (conjugada) }\end{array}$ & & $\begin{array}{l}\text { Doença invasiva caudada pela Neisseria } \\
\text { meningitidis tipo C }\end{array}$ \\
\hline \multirow{3}{*}{4 anos } & Tríplice bacteriana (DPT) & \multirow{3}{*}{$\begin{array}{l}2^{\circ} \\
\text { reforço }\end{array}$} & Difteria, tétano e coqueluche \\
\hline & Vacina oral poliomielite (VOP) & & Poliomielite ou paralisia infantil \\
\hline & Tríplice viral (SCR ou MMR) & & Sarampo, caxumba e rubéola \\
\hline
\end{tabular}

BCG: bacilo de Calmette Guérrin; DTP: difteria, tétano e coqueluche; Hib: Haemophilus influenzae tipo B; SCR: sarampo, caxumba e rubéola; MMR: sarampo, caxumba e rubéola em inglês - measles, mumps and rubella. *Calendário básico de vacinação da criança vigente na época de realização do campo de pesquisa. O que vigora atualmente já apresenta alterações. 
desigual de bens econômicos, divisão preferencial de prerrogativas políticas e diferenciação discriminatória de valores culturais. No convite e esclarecimento da proposta do estudo, era colocado aos candidatos o recorte social alvo, e foi levado em consideração, além da escolaridade de nível superior, a percepção de pertencimento e identificação à camada média pelos próprios casais.

Também foi pensado em incluir apenas casais que tivessem filhos hígidos, evitando casais de crianças prematuras, que apresentassem história de problemas de saúde intra-útero ou no período perinatal ou doenças crônicas pré-diagnosticadas. A intenção foi evitar que a escolha de vacinar ou não seus filhos fosse influenciada sobretudo por questões de saúde ou médicas protocolares, dando prioridade à dimensão do cuidado parental. Na população escolhida, teve um casal cujo filho foi prematuro. Ele não foi excluído pela riqueza das falas e por considerar, conforme a intenção prévia, que a prematuridade neste caso específico não foi preditor, nem determinante das escolhas deste casal, mas foi usada apenas como desculpa para postergar a vacinação (conduta já em consenso pelos pais antes da ocorrência do parto prematuro).

O número final de casais participantes não foi definido a priori e sim durante o trabalho de campo, a partir das informações produzidas no período de levantamento dos dados, usando o critério de saturação teórica (Fontenella et al., 2008). Nesse estudo a saturação foi considerada no momento em que se alcançou um corpus de falas, cuja riqueza possibilitou a emergência de significados atribuídos à experiência da (não) vacinação dos filhos no contexto do cuidado infantil dessas famílias. Ou seja, quando a pesquisadora percebeu que os depoimentos de novos participantes pouco acrescentariam ao material empírico já obtido, para a conformação das categorias temáticas, para a riqueza dos dados e aos sentidos das categorias analíticas, uma vez que o objeto de estudo foi a interface sobre o processo pela (não) vacinação e cuidado infantil. Se o foco do estudo fosse explorar a diversidade das razões para vacinar, selecionar ou não vacinar, a amostra aqui conformada não teria atingido o critério de saturação, sobretudo no grupo dos que selecionaram. Neste caso (não no presente estudo), captar novos casais poderia, muito provavelmente, contribuir para novas informações e aperfeiçoamento do estudo.

O número final de participantes foram 16 casais, dos quais cinco vacinaram os filhos, cinco selecionaram as vacinas e seis casais não vacinaram os filhos (cinco casais 
e um com participação da mulher, sem o marido). De todos os casais convidados, apenas um pai não participou, a pedido de sua esposa, que colocou como condicional para sua participação, a exclusão do marido do estudo.

Topo ajudar sem problemas, desde que seja confidencial. A questão é a participação do meu marido. Ele não tem a mesma opinião que a minha em relação à vacinação. (...) Com auxílio da médica fui adiando a vacinação e nosso combinado sobre o assunto foi que somente discutiríamos o caso da vacinação quando ele se informasse a respeito (assim como fiz) e pudesse argumentar além do "todo mundo toma". Ele concordou, mas não foi em busca de informação, prevalecendo minha opinião de não vacinar. Porém, é um assunto ainda um pouco difícil entre nós. (...) Portanto, conversar com ele sobre o assunto, ainda mais em particular, pode reavivar certas dúvidas, deixá-lo confuso e portanto, me causar problemas, como por exemplo, do nada, resolver que quer vacinar agora ou voltar a questionar nossa decisão, que foi mais minha do que dele. Se a entrevista puder ser somente comigo, ok. Tenho receio que a participação dele possa criar atritos no nosso relacionamento. É uma situação um tanto delicada... Não costumamos tocar muito no assunto para evitar discussões. Se para você não tiver problemas, por mim é só marcar (Elaine).

A incorporação da Elaine no estudo, mesmo ferindo os critérios estabelecidos para conformar a população do estudo que propõe entrevistar o casal, se baseou na percepção de que sua história poderia contribuir para questões relevantes sobre o tema e revelar a dimensão do cuidado e da escolha pela não vacinação mesmo na ausência do depoimento do marido.

O convite aos participantes foi realizado por telefone ou por e-mail. Iniciava com minha apresentação, identificava a fonte de indicação do casal e expunha: o objetivo do estudo, sua temática e população alvo; por qual Instituição ele estava sendo feito e que consistia num projeto de pós-graduação; que era por meio de entrevistas tanto para homens quanto para as mulheres; que as entrevistas eram gravadas e posteriormente transcritas e enfatizava o rigor ético quanto ao anonimato $\mathrm{e}$ confidencialidade dos participantes e das falas. De um modo geral, o primeiro contato era com a mulher e ela pedia um tempo para expor a proposta ao seu parceiro e depois me retornava ou eu retornava para ver a resposta. Para aqueles em que o contato era por 
e-mail, era enviado em anexo o resumo do trabalho e o Termo de Consentimento Livre e Esclarecido (anexo 2), para uma análise mais profunda pelas pessoas convidadas. Houve uma resistência inicial de dois casais que não vacinaram os filhos, por eles tratarem esta temática de forma sigilosa. Para estes foi preciso reforçar as garantias éticas já expostas e que a participação era voluntária e, após muitos esclarecimentos, concordaram em participar.

Após o aceite do casal, vinha o planejamento de procurar o melhor local, data e hora para o encontro. Estes foram escolhidos pelos participantes da pesquisa, mediante contato telefônico ou por e-mail, garantindo conforto e privacidade.

As entrevistas foram executadas em momentos separados (alguns em locais e datas separados) com o homem e a mulher em 14 casais e num mesmo momento, em conjunto, em dois casais. Esta diversidade de formato teve o intuito de enriquecer os dados empíricos: quando realizado em separado, possibilitou potencializar o espaço de diálogo com cada pessoa sem a interferência do parceiro; e quando em conjunto, possibilitou captar dimensões do cuidado e da dinâmica familiar no próprio momento da entrevista.

No término de cada entrevista foram feitas anotações no diário de campo sobre as impressões do relato, as expressões e reações dos entrevistados, as maneiras de agir entre outros tópicos que se mostraram relevantes. Esses dados foram usados como técnica auxiliar para a análise e interpretação dos dados, e serão expostos no tópico 4.3 "Impressões da pesquisadora-intérprete durante o trabalho de campo".

As entrevistas foram realizadas entre janeiro/2011 a julho/2011. Elas foram gravadas em áudio digital de forma ininterrupta e duraram entre 7 a 68 minutos, com média de 34,6 minutos. O conjunto das entrevistas totalizou um banco de dados em áudio de 971 minutos. Todas as entrevistas gravadas foram transcritas na íntegra obedecendo algumas orientações de Gomes et al. (2005): trabalhar com as palavras faladas sem trabalhar com as características paralinguísticas; os nomes dos entrevistados e mencionados por eles foram trocados por nomes fictícios, para garantir o anonimato e feita a conferência de fidedignidade da transcrição com as falas originais. 


\subsection{Aspectos éticos}

Este estudo seguiu as recomendações da Resolução CNS n 196/96 do Conselho Nacional de Saúde - Comissão Nacional de Ética em Pesquisa (CONEP) e obteve aprovação do Comitê de Ética em Pesquisa da Faculdade de Medicina da Universidade de São Paulo (CEP-FMUSP). Inicialmente, na forma do projeto de mestrado intitulado "Parentalidade e cuidado: representações de pais e mães acerca da vacinação dos filhos", consentido pelo protocolo $\mathrm{n}^{\circ}$ 251/10 (anexo 3); e posteriormente, fazendo parte do projeto mais amplo "Gênero, parentalidade e cuidado: representações de pais e mães de camada média urbana acerca da amamentação, alimentação e vacinação de seus filhos", aprovado pelo protocolo no $167 / 12$.

Respeitando as diretrizes do Programa de Pós-Graduação do Departamento de Medicina Preventiva da USP, o projeto inicial de mestrado foi aprovado para doutorado direto em 24/05/2012. Essa passagem propiciou a mudança do título inicial para o atual, “Cuidado infantil e (não) vacinação no contexto de famílias de camadas médias em São Paulo/SP”. Como o teor e corpo exigidos ao nível de doutorado se deu, neste caso, exclusivamente pelo aprofundamento teórico e analítico-interpretativo, sem alteração do campo de pesquisa na obtenção dos dados empíricos, a Comissão de Pós-Graduação deste Departamento aprovou a mudança do título sem a necessidade de reavaliação pelo CEP-FMUSP.

Como anteriormente exposto, na etapa de convite dos participantes, por contato telefônico ou via e-mail, eram expostas as questões éticas do estudo. No encontro com os entrevistados, foram novamente apresentados o conteúdo e o propósito da pesquisa e foi indagado sobre o aceite em participar. O Termo de Consentimento Livre e Esclarecido (TCLE) (anexo 2) foi lido pelo participante e, após solucionadas eventuais dúvidas do(a) entrevistado(a), foi assinado.

Foram garantidos o anonimato e a confidencialidade dos dados e dos participantes da pesquisa, bem como a possibilidade de interromper a entrevista a qualquer momento, em conformidade com os termos do TCLE. Para tanto, todos os nomes dos entrevistados, assim como os dos filhos e outros sujeitos por eles citados como parentes, médicos, amigos etc., foram trocados por nomes fictícios. 


\subsection{Percurso analítico-interpretativo}

O processo percorrido teve como base os pressupostos de contextualização dos depoimentos e dos participantes do estudo; valorização do material empírico coletado, com uma postura de respeito ao que foi dito, pois sempre terá racionalidade e sentido; empatia, levando à compreensão das razões que fizeram com que o sujeito da pesquisa elaborasse o relato da forma que o fez e tratar a interpretação de dados como algo em aberto e passível de compartilhamento com os participantes da pesquisa (Minayo, 2008).

A trajetória analítico-interpretativa iniciou-se com a leitura extensiva dos dados empíricos. Ela partiu da leitura compreensiva de todas as entrevistas transcritas, de forma minuciosa e atenta, até atingir a impregnação de seu conteúdo, que possibilitou a apreensão da lógica interna, das particularidades e, ao mesmo tempo, da visão de conjunto. Após a impregnação do material empírico, foi novamente realizada a leitura compreensiva, agora direcionada pela classificação conforme a escolha pela vacinação dos filhos (casais que vacinaram, que selecionaram e que não vacinaram os filhos), na intenção de alcançar uma visão mais ampla dos sentidos e significados de cada grupo, assim como as possíveis convergências e divergências. No momento seguinte, a leitura se conformou de acordo com o sexo dos entrevistados, com o intuito de explorar as relações de gênero nos casais, referentes à conjugalidade e parentalidade envolvidas no processo de (não) vacinação dos filhos, no interior da família.

Após a imersão na leitura das transcrições, foram feitos recortes temáticos que culminaram na identificação das categorias empíricas (tabela 2). Uma parte das categorias empíricas era prevista pelos objetivos do estudo e conformação do roteiro, como o universo da vacinação infantil (concepções, práticas, valores, influências etc.),e como a vacinação do filho está inserida no cuidado infantil dessa família na dinâmica familiar, nas relações de gênero e geração. Outras categorias empíricas, porém, emergiram dos dados empíricos, e se destacaram pela frequência e intensidade que apareceram nos relatos dos participantes de pesquisa, como as concepções sobre risco e proteção em saúde, sobre autonomia nas decisões de saúde do filho, sobre as práticas em saúde envolvendo o parto e os cuidados infantis e o papel das informações em saúde, sobretudo as disponíveis na internet. 
Após a impregnação e elencadas as categorias empíricas, foi realizado o processo de organização das transcrições das entrevistas, através da ferramenta Nvivo9, versão em português. Trata-se de um programa que auxilia na ordenação de cada fragmento dos depoimentos nas categorias empíricas identificadas. Por meio desse software, o material empírico foi organizado de duas maneiras: por entrevista, em que foi realçado o fragmento de fala que anuncia uma ou mais categoria empírica e por categoria empírica, compostas pelos fragmentos dos depoimentos.

Tabela 2: As categorias de empíricas

\begin{tabular}{l|l}
\hline \multicolumn{2}{c}{ CATEGORIAS PREESTABELECIDAS } \\
\hline & \begin{tabular}{l} 
Concepções e práticas no tocante à vacinação; \\
Valores atribuídos às vacinas; \\
Sentimentos perante a decisão de vacinar ou não; \\
Concepções sobre os serviços públicos e privados de \\
vacinação; \\
$\begin{array}{l}\text { Influências para a tomada de decisão sobre a vacinação } \\
\text { infantil; } \\
\text { Percepções e atitudes sobre o meio externo (família e círculo } \\
\text { social) no tocante à tomada de decisão sobre vacinação. }\end{array}$ \\
\hline $\begin{array}{l}\text { O cuidado e a escolha } \\
\text { da (não) vacinação } \\
\text { infantil na família }\end{array}$
\end{tabular}$\quad \begin{array}{l}\text { Relações parentais (dimensões de maternidade, paternidade), } \\
\text { conjugal, e de geração. }\end{array}$ \\
\hline
\end{tabular}

CATEGORIAS QUE EMERGIRAM DOS DADOS EMPÍRICOS

Concepções sobre riscos e proteção acerca da vacinação

Concepções sobre autonomia nos cuidados em saúde da criança

\begin{tabular}{l|l}
\hline \multirow{3}{*}{ Práticas de saúde } & $\begin{array}{l}\text { Percepções sobre as posturas dos médicos e outros } \\
\text { profissionais de saúde no tocante à vacinação; } \\
\text { Concepções sobre a obstetrícia e as práticas no parto; } \\
\text { Percepções sobre as práticas atuais de saúde à criança. }\end{array}$ \\
\hline
\end{tabular}

\section{Informação em saúde e sobre vacinação}

Por meio do recurso de análise de conteúdo temático (Fontana; Frey, 2000), os passos seguintes foram: confrontar as categorias empíricas com os referencias teóricos elencados nesse estudo [cuidado por Ayres (2001, 2003, 2004), família na camada 
média urbana e sua interface com a sociedade complexa contemporânea por Velho (1987, 1994) e gênero por Scott JW (1995, 2005)]; a construção das categorias analíticas; o cotejamento com a literatura científica; a busca pela compreensão de sentidos socioculturais mais amplos, subjacentes às falas dos participantes da pesquisa: "uma reinterpretação, ou seja, a interpretação das interpretações" (Gomes et al., 2005: 207); e, por fim, a elaboração da síntese interpretativa.

As categorias analíticas construídas nesse estudo foram: (1) a tomada de decisão sobre a (não) vacinação dos filhos; (2) o cuidado infantil e a (não) vacinação; (3) a (não) vacinação infantil na vida privada e (4) a vacinação infantil: reflexões sobre a relação indivíduo-coletivo; cada uma interpretada e sintetizada em capítulos, após a descrição dos casais pesquisados.

\section{$O$ aporte da antropologia interpretativa geertziana}

No processo analítico-interpretativo, o olhar aos depoimentos, ao contexto e à conexão destes com o momento histórico e sociocultural, se guiou pela antropologia interpretativa ou antropologia hermenêutica de Clifford Geertz.

Geertz deixou seu legado ao escrever sua principal obra "A interpretação da Cultura" em 1973, sendo considerado o protagonista da virada interpretativa na Antropologia (Azzan Jr, 1993; Fonseca, 2008). Ele defende que a pesquisa e a ação antropológicas, que tradicionalmente foram fundamentadas numa atividade descritiva e observacional, devam ser norteadas por meio de um processo interpretativo, por uma busca de significados como forma de conhecimento: a ciência interpretativa (Azzan Jr, 1993; Fonseca, 2008).

$\mathrm{O}$ autor propõe a metodologia hermenêtica-interpretativa para se acessar à "realidade", ou melhor, uma realidade circunscrita e contextualizada, a vida real das pessoas e as ações sociais, buscando a compreensão por meio da perspectiva intersubjetiva. Geertz sugere o (com)partilhamento da intersubjetividade como a ponte para o encontro dos olhares do intérprete/pesquisador com o interpretado (Azzan Jr, 1993; Fonseca, 2008).

Geertz apoia-se na abordagem semiótica para a compreensão da cultura, em contraponto às tendências estruturalistas e cognitivistas. Para além de falar de ou pelo 
outro, mas sim por meio da conversa com o outro, a dimensão dialógica do humano, é que se torna possível ter acesso ao contexto cultural com seus "signos interpretáveis", cujo sentido está sempre atrelado a um sentido-para alguém (Azzan Jr, 1993). A ação antropológica, nesta perspectiva, ampliaria o horizonte normativo de tratar os nossos informantes não como objetos de estudo, e sim abordá-los como pessoas, possibilitando "pensar não apenas realista e concretamente sobre eles, mas, o que é mais importante, criativa e imaginativamente com eles" (Geertz, 2008: 17, grifos do autor).

O autor enfatiza e coloca como ponto central a ação social, a qual tem e produz um sentido próprio, proporcionando um entendimento sobre o mundo. Geertz resgata e valoriza o trabalho de campo, em especial a etnografia, no qual o pesquisador entraria em contato real com a ação social que busca interpretar (Azzan Jr, 1993). As ênfases na vida real e nas ações sociais sustentam a proposta de Geertz de realizar um percurso partindo do particular, da parte, sem se preocupar com generalizações. Ressalta que "qualquer generalidade que consegue alcançar surge da delicadeza de suas distinções, não da amplidão de suas abstrações.” (Geertz, 2008: 17).

Ademais, Geertz propõe que a ação social tenha que ser tratada como texto a se interpretar. Ação e texto se aproximam na medida em que possuem vida própria, e adquirem autonomia ao "se destacar" de seus agentes. Desta maneira, rejeitando a visão estruturalista de tratar as ações sociais como códigos a se decifrar, Geertz sugere que ao abordar a realidade como texto, como constructos imaginativos inscritos de situações concretas sociais, seria um caminho - não o único - de se ter acesso à compreensão das formas simbólicas (percepções, significados, emoções, atitudes etc.) da experiência vivida pelas pessoas (Azzan Jr, 1993).

A cultura de um povo é um conjunto de textos, eles mesmos conjuntos, que o antropólogo tenta ler por sobre os ombros daqueles quem eles pertencem. (...) Esta não é a única maneira de se ligar sociologicamente com as formas simbólicas. (...) Mas olhar essas formas como "dizer alguma coisa sobre algo", e dizer isso a alguém, é pelo menos entrever a possibilidade de uma análise que atenda à sua substância, em vez de fórmulas redutivas que professam dar conta dela (Geertz, 2008: 212).

Assim, com a inspiração na semiótica e com o recurso da hermenêutica, Geertz propõe que a trajetória interpretativa recorra ao círculo hermenêutico denominado por Dilthey, fazendo a ponte entre a análise das formas simbólicas particulares de 
determinada ação social; com a contextualização destas numa estrutura de significado maior, na qual esta ação tem e, ao mesmo tempo, produz significado (Azzan Jr, 1993).

A refiguração do pensamento social proposto por Geertz, por meio da abordagem semiótica e interpretativa da cultura, proporcionou uma mudança paradigmática de uma busca pela compreensão e não pela explicação; de uma busca por sentidos e não de leis; de falar com alguém e não apenas falar de ou por alguém; e de preocupar-se com a ação social e a vida real das pessoas ao invés de estudar um espaço ou locus.

Esta mudança, por sua vez, torna o trabalho antropológico eminentemente contestável e um processo em constante desenvolvimento: “A antropologia, ou pelo menos a antropologia interpretativa, é uma ciência cujo progresso é marcado menos por uma perfeição de consenso do que por um refinamento do debate. O que leva a melhor é a precisão com que nos irritamos uns aos outros" (Geertz, 2008: 20).

Mas como estudar homens e mulheres de camada média escolarizada de São Paulo, da qual faço parte? Como me aproximar dialogicamente e empaticamente deles e, ao mesmo tempo, ter um distanciamento necessário para captar estas experiências e vivências e interpretá-las? Como diferenciar o que me é familiar, com constructos sociais preconcebidos e estereotipados deste meio em que vivo, com a realidade a qual busquei interpretar?

Percorrendo uma trajetória científica interpretativa, Gilberto Velho (1987), ao estudar a camada média urbana escolarizada de Copacabana, Rio de Janeiro - seu objeto de estudo e ao mesmo tempo local onde morava -, fez uma explanação de como observar o familiar, que orientou este estudo.

Velho relativiza o termo familiar, sobretudo nas sociedades complexas urbanas contemporâneas. O que vivemos e sentimos como familiar não necessariamente é conhecido, e vice e versa. A aproximação social e psicológica compartilhada por vivências e experiências comuns entre o mundo do pesquisador/intérprete com o do interpretado, como no meu caso, é heterogêneo, tanto no grau de familiaridade, quanto no de conhecimento. Haverão cenários e situações sociais que vão gerar estranheza e não reconhecimento, possibilitando a relativização, e melhor, a transcendência da familiaridade, o estranhamento crítico perante o próximo, para se almejar compreender os sentidos e significados que o pesquisador busca interpretar. 
Acredito que seja possível transcender, em determinados momentos, as limitações de origem do antropólogo e chegar a ver o familiar não necessariamente como exótico, mas como uma realidade bem mais complexa do que aquela representada pelos mapas e códigos básicos nacionais e de classe através dos quais fomos socializados. O processo de estranhar o familiar torna-se possível quando somos capazes de confrontar intelectualmente, e mesmo emocionalmente, diferentes versões e interpretações existentes a respeito de fatos, situações (Velho, 1987: 131, grifo do autor).

O autor elenca duas vantagens de se estudar e estranhar o "familiar": a possibilidade de confrontar a apreensão da realidade preconcebida do pesquisador com a explorada a posteriori pelo estudo; e a maior facilidade de expor os achados com a população estudada, dada a proximidade, cujo confronto pode gerar valiosa contribuição para rever e enriquecer os resultados da pesquisa.

Tanto a aproximação quanto o distanciamento dos "mundos" do pesquisador/intérprete com o interpretado pode ser objeto de reflexão, deixando claro que a "realidade" estudada será absorvida e percebida sob o olhar do pesquisador. Isto reforça a impossibilidade e o despropósito de imparcialidade ou neutralidade em um percurso semiótico-interpretativo pelo conhecimento; sem reduzir, por sua vez, o rigor científico. Velho, assim como Geertz, reafirma o caráter não definitivo, potencialmente discutível, de uma objetividade relativa, devido à proposta (inter)subjetivista deste processo (Velho, 1987).

Vale ressaltar que os referenciais teóricos de cuidado, família na camada média urbana e sua interface com a sociedade complexa contemporânea e de gênero são interrelacionados e se dialogam com a antropologia interpretativa, já que são permeados pela dimensão relacional e dialógica do encontro com o outro, pela valorização da experiência vivida pelo sujeito e das interações interpessoais e pela importância da contextualização histórico-cultural da intersubjetividade.

\subsection{Impressões da pesquisadora-intérprete durante o trabalho de campo}

Tendo em vista a impossível neutralidade e distanciamento entre o sujeito pesquisador-intérprete e o sujeito pesquisado-interpretado, em especial na abordagem qualitativa, cuja dimensão relacional pode ser elemento de grande importância e 
especial interesse na compreensão do objeto de estudo, achei relevante discorrer sobre algumas impressões e percepções sobre os participantes da pesquisa; situações inusitadas durante as entrevistas e meu processo de transformação, no decorrer do trabalho de campo.

Os contatos iniciais por telefone ou e-mail aos "convidados" foram de um modo geral tranquilos, realizados na sua maioria com as mulheres. Essas mulheres conversavam com seus respectivos maridos e davam o retorno sobre a confirmação ou não da participação, fazendo assim a intermediação dos seus parceiros comigo. Chamou-me a atenção já antes de entrevistar estes casais, a desigualdade de gênero neste processo. Parecia que a mulher aprovava a participação e insistia/convencia seu parceiro para participar. Apenas em dois casais (dos 16), o contato inicial se de deu a partir do homem, mas mesmo nestes, após o aceite desses casais, a negociação do lugar, data e hora foi feito pelas mulheres. Havia uma naturalidade e certo interesse das mulheres sobre a temática e, em sua maioria, um distanciamento dos homens. Tais posturas frequentes reforçam a ideia socialmente construída que a saúde infantil (a também a vacinação) é de interesse e função femininos. Em contraponto, essas mulheres expressaram certo poder na negociação sobre a participação dos parceiros no estudo.

Nos casais que não vacinaram os filhos, houve o predomínio de duas posturas iniciais, ao meu primeiro contato e convite para participar do estudo. Uma de receio e desconfiança, pela consciência de estarem fazendo algo fora da lei e medo de denúncia. Para esses casais, nosso contato inicial foi um processo mais moroso, em que tive que reafirmar inúmeras vezes o caráter anônimo e confidencial do trabalho, até conquistar a confiança necessária para eles participarem voluntariamente. Principalmente em um desses casais, houve uma grande resistência inicial, na qual entrou a rara presença masculina nesta fase do convite/negociação, cujo convidado Vinícius mostrou interesse e, ao mesmo tempo, expôs duros questionamentos e dúvidas sobre a temática, principalmente sobre o objetivo, a segurança e o sigilo do estudo. Neste caso houve considerável tensão, mas que resultou, após exaustivos esclarecimentos e garantia de segurança e confidencialidade totais, ironicamente, em um dos melhores narradores e a entrevista de maior tempo dos homens (1 hora e 8 minutos) e a segunda maior de todos os entrevistados. 
A outra postura dos casais que não vacinaram os filhos, em contraste, porém não menos difícil de lidar, foi da aceitação imediata e com muita empolgação para participarem do estudo, revelando a carência de interlocutores desses pais. Era como se eles quisessem uma cumplicidade "oficial", uma "apoiadora" legítima à sua causa: "Lógico, que bom que têm pessoas que se interessam sobre esse assunto, para mostrar que eu não sou uma mãe louca!" (Amanda).

Além do relatado nestes episódios, o mais complicado nesta etapa de trabalho foi marcar a data e o horário dos encontros, não tanto pela minha agenda, pois tive flexibilidade e conseguia disponibilizar para o campo as manhãs, as noites e finais de semana, mas sim, pelo pouco tempo e agenda apertada dessas mulheres e desses homens trabalhadores, com filhos e residentes em São Paulo. Essa dificuldade de conciliar as agendas e principalmente a falta de tempo quase que generalizada, além de gerar em mim uma profunda reflexão do que estamos fazendo e que escolhas de vida são essas, me causou uma sensação de desconforto, como se eu estivesse atrapalhando um momento livre tão raro na vida dessas pessoas.

Talvez isso, somado à minha timidez e inexperiência em entrevista qualitativa $\mathrm{e}$ gravada, culminaram na minha dificuldade inicial nas primeiras entrevistas (que tiveram qualidade inferior e menor tempo). Trazendo uma bagagem prévia de estudos epidemiológicos quantitativos, fui condicionada a manter uma distância do sujeito de pesquisa e inicialmente seguia o roteiro de maneira mais rígida. Após várias conversas com minha orientadora, leituras sobre o método de entrevista em profundidade e a maior familiaridade com o dia a dia das entrevistas, pouco a pouco, me desinibi e coloquei-me de forma mais confiante, passando a conduzir as entrevistas com tranquilidade e aprimorando sobre os melhores momentos de cortar, explorar e retomar os depoimentos de acordo com a condução do próprio narrador. Não tenho dúvidas sobre a superioridade da qualidade das últimas entrevistas em relação às primeiras, sendo talvez uma grande prova que o processo de aprendizado na pós-graduação se dê em todas as etapas do processo.

Nos contatos com as mulheres de um modo geral, tive uma impressão de identificação inicial, tanto pelo fato de ser mulher, quanto por ser da mesma camada social paulistana, em que eu senti muita abertura da parte delas, como se estivesse falando com uma "igual". Porém, em determinado momento, tal identidade sofreu certo 
abalo: as mulheres, quase em sua totalidade (independente da escolha pela vacinação), em algum momento da entrevista me perguntavam "Você tem filhos?". Ao responder que não, percebia uma decepção contida ou disfarçada, como se houvesse um universo que eu não pudesse mais acessar, exclusivo da maternidade, por exemplo, "quando você for mãe você vai entender", com potencial de afetar, em grau variado, nossa capacidade de interlocução. Isso aconteceu de forma quase que generalizada, às vezes antes, no decorrer ou após a entrevista, exceto nas mulheres que me conheciam, mesmo que de forma distante, e que já sabiam que eu não tinha filhos. O que mudou com o passar do tempo foi o meu maior desconforto com a pergunta e a minha naturalidade em respondê-la.

Os homens, de um modo geral, mostraram um distanciamento maior, gerando uma situação menos confortável bilateralmente. Talvez por eu ser mulher ou por ser da área de saúde e indagá-los sobre algo que dominavam menos tecnicamente. Neste relacionamento, senti de alguns um anseio em justificar o porquê "não sabe" como "tenho muito trabalho, não tenho tempo..."; ou "está tudo certo com a vacinação do nosso filho, mas eu não sei detalhes, pois quem cuida disso é minha esposa...”. Isso foi expresso também pelo tempo mais curto das entrevistas, se comparado com suas esposas.

Conheço tão pouco o assunto que tenho pouco pra acrescentar. Mas essa história do Zé gotinha, das campanhas maciças, eu acho uma coisa muito positiva que existia, nem sei, por que não tem tanto hoje? Por que está enraizado? Já tá na cultura do povo? (...) Então é isso, o que mais eu poderia acrescentar? Acho que muito pouco sobre esse assunto... (risos) (Bruno).

Dentre as dificuldades no campo, gostaria de ressaltar duas entrevistas com homens que achei curiosas, ilustram imprevistos difíceis de lidar e que reforçam certo desinteresse ou descompromisso com a entrevista, a temática, comigo e/ou com a pesquisa em geral. Rafael marcou comigo o encontro no trabalho dele, em uma escola onde lecionava educação física. Inicialmente íamos fazer a entrevista em alguma sala de aula após o término de uma reunião de professores às 19 horas. Quando eu o encontrei (na porta da escola), ele me disse que preferiria que a entrevista fosse em outro lugar, e sugeriu uma lanchonete próxima dali. Disse que estava sem carro e perguntou se eu não podia dar uma carona para ele. Tranquilamente disse que sim e, no que entramos no carro, ele perguntou se a entrevista não poderia ser no carro mesmo, no caminho para a casa dele. Sem graça e sem saber como responder, consenti e assim ocorreu a entrevista 
mais estranha, numa carona minha para a casa dele, que durou 18 minutos. No dia seguinte a esposa, após saber do ocorrido, me mandou um e-mail dizendo que estava completamente envergonhada e pediu desculpas por ele.

O outro, Guilherme, marcou comigo numa praça em frente à casa dele, assim como sua mulher. Porém, neste dia ele também marcou com o pai dele no mesmo lugar e hora. Assim, ele claramente deu uma entrevista muito rápida (a mais curta de todas, com 8 minutos), com face de apressado, olhando para o pai, num cenário de crianças brincando, cães latindo etc. A última frase de sua narrativa foi "e qual o objetivo da pesquisa assim? Agora fiquei com uma dúvida aí”. De imediato tive um sentimento de indignação: “Como ele faz uma pergunta dessa, após eu ter explicado sobre o estudo, sua finalidade e sobre o TCLE? Como, após tudo isso, ele dá uma entrevista com pressa e faz tal indagação no final?" Num segundo momento, este fato serviu de reflexão sobre minha comunicação com meus interlocutores. Será que expliquei com clareza o objetivo do estudo? O tempo e a maneira dessa prévia à entrevista atingem todas as possíveis dúvidas e esclarecimentos aos participantes da pesquisa, tanto pelo meu compromisso ético com eles, quanto em benefício à qualidade dos dados a serem gerados?

Estas reflexões somadas às orientações geraram uma mudança na abordagem inicial com os participantes e na minha postura, em que eu me apresentava, dizia quem eu era, o que fazia, o objetivo do estudo, onde ele estava sendo realizado, porque surgiu a ideia de realizar este estudo, que era por meio de entrevista gravada, de caráter aberto ao entrevistado, em que ele podia expor suas falas à vontade com liberdade, que eu não ia perguntar sobre o conhecimento dele sobre vacinação ou sobre a carteira vacinal do filho (o que ele tomou ou não), que iria abordar como ele viveu a experiência do cuidado infantil e a vacinação, que antes de chegar na temática da vacinação eu ia abordar outros tópicos como a gestação, o parto e os cuidados do dia a dia, etc.; além de falar sobre as considerações éticas da pesquisa e sobre o TCLE. Essa mudança reforçou em mim maior segurança no campo e, sinergicamente, maior compreensão dos participantes, contribuindo em muito na melhora da qualidade dos dados e depoimentos.

Desde então, se eu passasse por estas duas situações descritas anteriormente, minha postura e conduta seriam bem diferentes, em que eu provavelmente iria propor outro momento para o encontro, devido à importância de ser em um lugar com privacidade e estar com tempo, entre outros argumentos e ressaltaria que seria 
completamente voluntária a participação na entrevista. Se o convidado discordasse, não tivesse interesse ou se mostrasse um mau narrador, eu agradeceria e procuraria outros sujeitos.

Nas entrevistas com algumas mulheres, a principal dificuldade técnica foi a presença dos filhos, que fizeram interferências durante um choro forte, crise de birra, hora de comer, ir ao banheiro etc. Em alguns momentos, estas interposições fizeram com que o ritmo das falas se quebrasse e desviasse a atenção, fazendo com que nos perdêssemos (“O que eu estava dizendo? O que você perguntou mesmo?”). Além disso, as interferências dificultaram as transcrições das entrevistas devido aos ruídos, porém sem afetar a qualidade final desses depoimentos.

Percebi uma preocupação que se repetiu, independente do sexo do participante, em "estudar" um pouco sobre vacinas e ver a caderneta de vacinação do filho para aqueles que a possuíam, antes de eu chegar. Falas como "pedi para minha mulher pegar o cartão de vacinação para eu saber quais vacinas meu filho tomou", "peguei o cartão vacinal para lembrar os nomes das vacinas" foram recorrentes. Após minha exposição inicial reforçando que não era objetivo saber o que sabe ou não, nem medir o conhecimento, percebi, principalmente nos homens, certo alívio. Ressalto duas mães que não vacinaram os filhos, Virgínia e Clara, que separaram extenso material impresso sobre vacinação, a maioria da internet, com o objetivo, conforme suas falas, de se lembrar de argumentos, nomes, artigos etc.; os quais, algumas vezes, foram fontes de consulta durante a entrevista.

O local para as entrevistas foi escolhido pelos participantes, conforme interesse, facilidade, tempo e conciliação das agendas, sempre visando garantir privacidade e conforto. A maioria deles escolheu as suas casas como melhor ambiente para tal propósito. As exceções foram: na praça em frente a casa (Guilherme e Helena); numa lanchonete (Vinícius); numa carona no meu carro (Rafael); no trabalho (Nicolas) e na escola do filho (Manuela). Já foram feitas as considerações sobre as entrevistas no carro, na praça e sobre as interferências das crianças quando as entrevistas eram nas próprias casas. As entrevistas realizadas nas casas dos participantes diversificaram da seguinte maneira: 1) em dois casais, as entrevistas foram feitas em conjunto; 2) em sete casais, no mesmo dia, porém em momentos separados (em que um ficava com a (s) criança (s) num cômodo e o outro comigo e, após o término, se revezavam); 3) em dois 
casais, as entrevistas foram na casa, mas em dias diferentes para cada parceiro e 4) em três, apenas as mulheres, sem seus parceiros.

Os dois casais que fizeram a entrevista em conjunto trouxeram dados interessantes. O primeiro casal, Beatriz e Alex, tiveram grande presença, incluindo falas de concordância e discordância com o parceiro, que enriqueceram, a meu ver, de sobremaneira os depoimentos, talvez mais se ocorressem em separado.

Beatriz: É muito engraçado, porque ele tem uma postura mais radical, inclusive mais radical que eu em relação ao discurso, a questão toda, só que no fundo ele não tem coragem. (...) Ele sempre tem esse discurso, mas ele não levou [o filho para ser vacinado], ele não consegue. (...)

Alex: É, tem uma certa violência no ato, e eu sou muito... Puta eu sofro demais. Parece que é comigo.

Já o outro casal, Paula e André, a entrevista em conjunto fez abafar as falas do André, já que quase sempre era a Paula que respondia, mesmo quando a pergunta era para o casal ou para ele diretamente: ele não respondia; ou apenas após a fala dela, dando poucas considerações; às vezes, inclusive ela respondia por ele. Podemos inferir que se a entrevista, neste caso, fosse em separado, seria de uma maior riqueza por parte do depoimento do André. Apesar disso, tal realidade no momento da entrevista pode reproduzir a dinâmica do casal na vida real, contribuindo para uma maior compreensão da lógica interna dessa família.

Nos casais em que houve o revezamento, ficou evidente em alguns casos que este esquema alimentou curiosidade, principalmente por parte da mulher, em relação ao relato de seu parceiro, tanto no que ele pensa, quanto para saber se bateu com a opinião que ela expressou sobre como eles viveram o cuidado e os aspectos ligados à vacinação do filho. Uma delas, Isabel entrou na sala umas duas vezes, durante a entrevista com seu parceiro Marcelo, para pegar um copo de água ou outra coisa na cozinha e demonstrou expressões de muita curiosidade a respeito dos relatos de seu parceiro, o qual, por sua vez, expôs certo desconforto, resultando em pausas nos depoimentos nos instantes em que isso ocorreu. Em dois casais, as mulheres perguntaram no final, ao se despedirem, "bateu o que a gente disse?".

Tais situações no momento da entrevista podem sugerir uma suspensão da realidade desses casais no dia a dia, a convite do pesquisador, revelando indícios sobre 
as relações de gênero no ambiente doméstico dessas famílias.

De um modo geral as entrevistas com os participantes que não vacinaram e que selecionaram foram maiores que as dos que vacinaram os filhos. Provavelmente por estes últimos demonstrarem certo estranhamento sobre a problemática do estudo, talvez devido à legitimidade da vacinação por eles.

Duas mulheres pontuaram a importância da minha pesquisa, uma por ter trazido à tona um assunto antes não refletido e outra pela expectativa de que este estudo possa corroborar aos seus anseios.

Me surpreende, pensar em pessoas que não vacinam. (...) Me instiga no sentido de me fazer pensar o que é essa postura de você questionar uma recomendação tão legitimada como é a vacinação, e me surpreende, eu não correria esse risco. Então eu acho que algo que a tua pesquisa vai me fazer pensar, e vou querer ler também para saber mais, para justamente poder iniciar um processo de reflexão sobre algo que antes era 'tem que vacinar, ponto', algo inquestionável para mim (Fernanda).

Eu estou muito feliz de finalmente conseguir conversar com você. Participar, mas é muito importante esse tipo de estudo, porque a ditadura da ciência, e essa questão das vacinas é uma questão tão sensível e os questionamentos que são feitos, os cuidados dos filhos. (...) É um tema tão fechado, ortodoxo, que não se discute. É isso. Tomara que a tua pesquisa contribua para isso (Sílvia).

Quase todos os participantes, homens e mulheres, vacinadores ou não, me perguntaram no final da entrevista: "E você, o que você acha sobre a vacinação? Qual sua opinião? Você vacinaria seus filhos, quando os tiver?” Pergunta que me angustiava, não pela minha opinião sobre as vacinas, mas pela ciência que a minha resposta poderia condicionar ou alterar o vínculo estabelecido ou o teor dos depoimentos. Apesar da minha concepção de vacina e das reflexões oriundas das vivências desse estudo, que foi tão transformador, busquei assim respondê-los, na medida do possível, com uma forçosa imparcialidade: "estou ainda pesquisando..." ou "vou aguardar os resultados do estudo..." 


\section{CASAIS PARTICIPANTES}

As características dos casais participantes deste estudo estão resumidas na tabela 3, apresentada na próxima página.

A idade dos participantes pesquisados variou de 24 a 41 anos. Nesta faixa, as idades das mulheres variaram entre 24 e 38 anos e as dos homens entre 29 a 41 anos. Predomina a faixa etária dos 30 anos de idade para ambos os sexos. A faixa etária evidencia que todos os participantes nasceram entre as décadas de 70 e 80 do século XX, período da história brasileira de implantação do PNI. Todos os participantes foram vacinados na sua infância, conforme seus relatos, mesmo os atuais pais que não vacinaram ou selecionaram as vacinas do filho.

Das dezesseis famílias (quinze casais e uma representada apenas pela Elaine, sem a participação do marido), oito tinham dois filhos e oito tinham um filho no momento da entrevista, reforçando a tendência moderna de famílias cada vez menores (Goldani, 1994).

Eles residiam em sua maioria em bairros da zona centro-oeste, mas também foram contempladas outras áreas da cidade de São Paulo-SP como Santana, Vila Gumercindo e Jabaquara.

Em relação à escolaridade, todos os participantes apresentaram nível superior completo, critério de inclusão no estudo, alguns acrescidos de especializações (MBA), mestrado e doutorado.

As profissões dos participantes englobaram as três grandes áreas - biológicas, exatas e humanas - em diversas atuações: 1) tecnológicas: engenharia (civis e de alimentos); 2) histórico-culturais: antropologia, professores, tradução; 3) ligadas aos recursos naturais: biologia; 4) assistenciais: psicologia, nutricionista, pedagogia; 5) gestão e comercial: administração, propaganda, relações comerciais, analista de gestão e sistema; 6) artísticas: arquitetura e 7) segurança: oficial da polícia militar. 
Tabela 3: Características dos participantes da pesquisa

\begin{tabular}{|c|c|c|c|c|c|c|c|}
\hline $\begin{array}{c}\text { Grupo de } \\
\text { estudo } \\
\end{array}$ & $\begin{array}{l}\text { Nome } \\
\text { fictício }\end{array}$ & Sexo & $\begin{array}{c}\text { Idade } \\
* \\
\end{array}$ & Profissão & Filho(s) $)^{* *}$ & $\underset{* * *}{\mathbf{A B E P}}$ & $\begin{array}{l}\text { Bairro em } \\
\text { São Paulo } \\
\end{array}$ \\
\hline \multirow{10}{*}{$\begin{array}{l}\text { Casais que } \\
\text { vacinaram }\end{array}$} & Helena & $\mathrm{F}$ & 33 & Administradora & \multirow{2}{*}{ João, M, 1 ano } & \multirow{2}{*}{$\mathrm{A} 2$} & \multirow{2}{*}{ Perdizes } \\
\hline & Guilherme & M & 36 & Administrador & & & \\
\hline & Jaqueline & $\mathrm{F}$ & 37 & Professora & \multirow{2}{*}{ Lia, F, 2 anos } & \multirow{2}{*}{$\mathrm{A} 2$} & \multirow[b]{2}{*}{ Butantã } \\
\hline & Camilo & M & 38 & $\begin{array}{l}\text { Analista de } \\
\text { gestão }\end{array}$ & & & \\
\hline & Beatriz & $\mathrm{F}$ & 33 & Arquiteta & \multirow{2}{*}{$\begin{array}{c}\text { Luan, M, } 2 \\
\text { anos }\end{array}$} & \multirow{2}{*}{ B1 } & \multirow{2}{*}{$\begin{array}{l}\text { Vila } \\
\text { Beatriz }\end{array}$} \\
\hline & Alex & M & 41 & Arquiteto & & & \\
\hline & Eduarda & $\mathrm{F}$ & 38 & Psicanalista & \multirow[b]{2}{*}{$\begin{array}{c}\text { Larissa, F, } 3 \\
\text { anos }\end{array}$} & \multirow[b]{2}{*}{$\mathrm{A} 2$} & \multirow[b]{2}{*}{$\begin{array}{l}\text { Sumarezinh } \\
\mathrm{o}\end{array}$} \\
\hline & Alessandro & M & 35 & $\begin{array}{l}\text { Psicanalista e } \\
\text { prof. } \\
\text { Universitário }\end{array}$ & & & \\
\hline & Fernanda & $\mathrm{F}$ & 35 & Psicóloga & \multirow{2}{*}{$\begin{array}{c}\text { Gabriela, F, } 3 \\
\text { meses }\end{array}$} & \multirow{2}{*}{$\mathrm{A} 2$} & \multirow{2}{*}{ Pinheiros } \\
\hline & Bruno & M & 39 & Engenheiro & & & \\
\hline \multirow{10}{*}{$\begin{array}{c}\text { Casais que } \\
\text { selecionaram }\end{array}$} & Andreia & $\mathrm{F}$ & 36 & $\begin{array}{l}\text { Relações } \\
\text { Internacionais }\end{array}$ & \multirow{2}{*}{$\begin{array}{c}\text { Téo, M, } 3 \\
\text { anos \& } \\
\text { Vivian, F, } 1 \\
\text { ano }\end{array}$} & \multirow{2}{*}{ B1 } & \multirow{2}{*}{ Vila Gomes } \\
\hline & Rafael & M & 36 & Personal trainer & & & \\
\hline & Isabel & $\mathrm{F}$ & 34 & Psicóloga & \multirow{2}{*}{$\begin{array}{c}\text { Luiz, M, } 6 \\
\text { anos \& } \\
\text { Janaina, F, } 4 \\
\text { anos }\end{array}$} & \multirow{2}{*}{ A2 } & \multirow{2}{*}{$\begin{array}{l}\text { Higienópoli } \\
\text { S }\end{array}$} \\
\hline & Marcelo & M & 35 & $\begin{array}{l}\text { Analista de } \\
\text { sistemas }\end{array}$ & & & \\
\hline & Cláudia & $\mathrm{F}$ & 24 & Pedagoga & \multirow{2}{*}{$\begin{array}{c}\text { Mateus, M, } 1 \\
\text { ano }\end{array}$} & \multirow{2}{*}{ B2 } & \multirow{2}{*}{ Vila Gome: } \\
\hline & Francisco & M & 34 & Tradutor & & & \\
\hline & Manuela & $\mathrm{F}$ & 30 & $\begin{array}{l}\text { Engenheira de } \\
\text { alimentos }\end{array}$ & \multirow{2}{*}{$\begin{array}{c}\text { Ângela, F, } 8 \\
\text { anos \& } \\
\text { Gabriel, M, } 1 \\
\text { ano }\end{array}$} & \multirow{2}{*}{ A2 } & \multirow{2}{*}{$\begin{array}{l}\text { Vila } \\
\text { Gumercind } \\
\text { o }\end{array}$} \\
\hline & Nicolas & M & 29 & $\begin{array}{l}\text { Engenheiro de } \\
\text { alimentos }\end{array}$ & & & \\
\hline & Sílvia & $\mathrm{F}$ & 35 & Assessora & \multirow{2}{*}{$\begin{array}{c}\text { Antônio, M, } 3 \\
\text { anos }\end{array}$} & \multirow{2}{*}{$\mathrm{A} 2$} & \multirow{2}{*}{ Santana } \\
\hline & Hugo & M & 29 & Professor & & & \\
\hline & Clara & $\mathrm{F}$ & 32 & Nutricionista & $\begin{array}{c}\text { Maria, F, } 4 \\
\text { anos \& }\end{array}$ & & Jardim \\
\hline & Jonas & M & 32 & $\begin{array}{l}\text { Representante } \\
\text { comercial }\end{array}$ & $\begin{array}{c}\text { Helena, F, } 3 \\
\text { meses }\end{array}$ & B I & Paulista \\
\hline Casais que & Paula & $\mathrm{F}$ & 34 & Bióloga & Kelly, F, 10 & & \\
\hline vacinaram & André & M & 35 & Publicitário & M, 4 meses & & \\
\hline & Ana & $\mathrm{F}$ & 36 & Engenheira & $\begin{array}{c}\text { Bruna, F, } 3 \\
\text { anos \& }\end{array}$ & & Alto de \\
\hline & Vinícius & M & 35 & Engenheiro & $\begin{array}{l}\text { Milena, } \\
\text { F, } 4 \text { meses }\end{array}$ & & Pinheiros \\
\hline
\end{tabular}




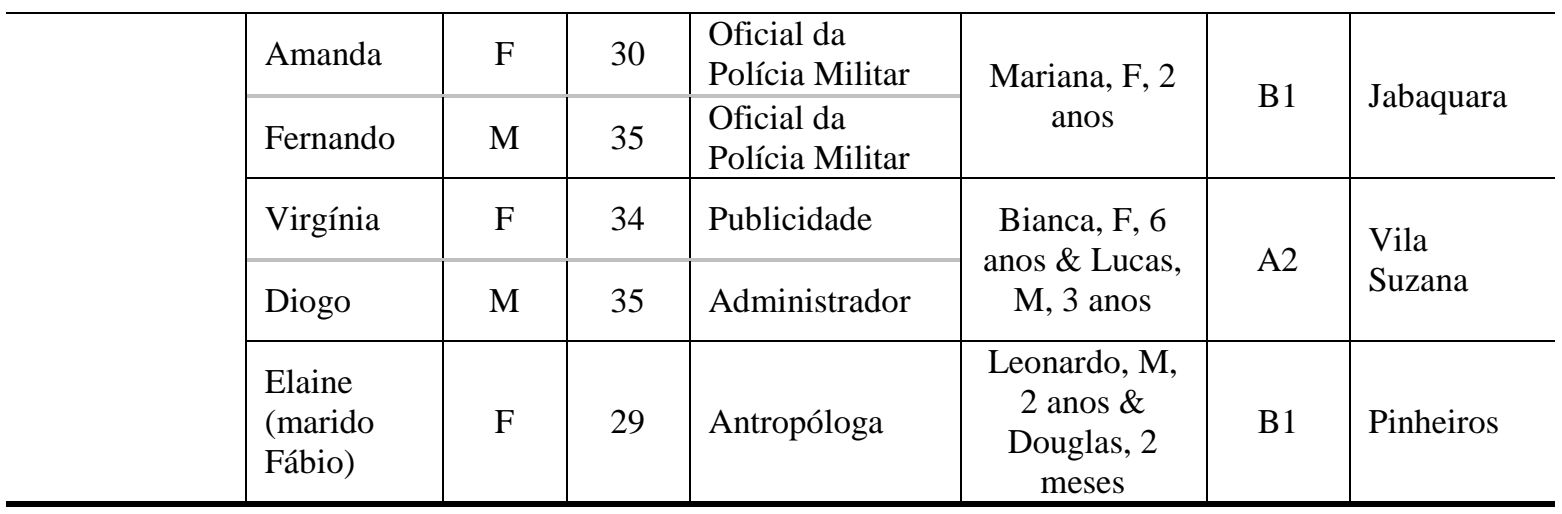

F: feminino, M masculino * Idade no momento da entrevista em anos. ** Nome fictício, sexo e idade do(s) filhos. *** Estratificação socioeconômica conforme ABEP (2011).

Incluiu tanto profissionais liberais, quanto com vínculo formal de emprego. Alguns exerciam parte do seu trabalho em casa. No momento da entrevista, Clara, Paula, Virgínia e Elaine optaram por abdicar do trabalho formal temporariamente, no máximo participando de ONGs ou trabalhos freelancers realizados em casa, para se dedicarem mais plenamente aos cuidados dos filhos. Apenas Francisco estava desempregado recentemente, realizando trabalhos de tradução esporadicamente.

A seguir serão realizadas as caracterizações dos casais, construídas a partir do contato com eles no momento da entrevista, das anotações do caderno de campo e dos depoimentos oriundos das primeiras perguntas do roteiro (desejo de ter filhos; vivência na gestação e parto; experiência nos cuidados diretos e cotidianos; vivência nas questões de saúde e no processo da (não) vacinação dos filhos). Os períodos de relacionamento conjugal, casamento ou amamentação dos filhos aparecem nos casais que os mencionaram. Sendo assim, alguns casais não relataram esses dados, uma vez que as perguntas do roteiro eram abertas e, como esses dados não eram decisórios para a compreensão do objeto desse estudo e sim complementares, não foram perguntados de maneira direta.

\subsection{Casais que vacinaram os filhos}

Jaqueline e Camilo: Eles se casaram e aguardaram terem mais estrutura para realização de ter filhos. Após quatro anos, com estabilidade financeira e mudança de casa, planejaram a gravidez. Fizeram tratamento para engravidar com medicamento e aí após 
quatro meses engravidou da Lia. A Jaqueline optou por parto cesárea e recebeu apoio do marido e do médico. A Lia foi amamentada com aleitamento materno exclusivo até cinco meses e meio e recebeu todas as vacinas recomendadas pelo médico, seguindo corretamente os tempos das doses. Iniciaram a vacinação na maternidade, escolheram dar as do calendário básico na Unidade Básica de Saúde (UBS) e, as que estavam fora do calendário básico do PNI, foram dadas em clínicas privadas (umas cobertas pelo convênio e a contra gripe que foi paga por eles).

Eduarda e Alessandro: A ideia de ter filhos veio desde o início do namoro. Após seis meses namorando decidiram morar juntos; e, após oito meses, planejaram a gravidez (Eduarda parou de fumar e suspendeu o anticoncepcional), engravidando da Larissa no mês seguinte. A Eduarda queria parto normal, e então escolheram um obstetra específico com esse fim, porém, uma intercorrência (a bolsa rota apresentou líquido amniótico com sangue) culminou na realização da cesárea. Eduarda reagiu de forma tranquila, pois o que mais importava era a criança nascer bem. Eles tiveram duas auxiliares de enfermagem para ajudar a cuidar da criança nos primeiros dois meses, e depois contrataram uma babá, porque Eduarda estava finalizando o mestrado e Alessandro estava com muito trabalho e se qualificando para o doutorado na época em que Larissa nasceu. Ela amamentou exclusivamente por seis meses. Iniciaram a vacinação na maternidade, deram todas as vacinas indicadas pelo pediatra, seguindo corretamente os tempos das doses e escolheram vacinar em clínica privada, para receber todas as vacinas disponíveis e dar menos picada. Pagaram as primeiras vacinas e depois elas foram cobertas pelo convênio recém-contratado. Deram apenas a contra a gripe na UBS durante a campanha.

Helena e Guilherme: Eles tinham namorado e estavam casados há muito tempo. Sentiram pelo círculo social e época da vida que estava na hora de pensar em ter filhos. Helena suspendeu o anticoncepcional e engravidou no mês seguinte de João. Ela tinha dúvidas sobre a via de parto, preferia parto normal, mas tinha insegurança. Com 41 semanas de gestação eles foram à maternidade, induziram o parto que não prosseguiu, e evoluiu para cesárea após alteração no batimento cardíaco do feto. Ela amamentou João por oito meses. Iniciaram a vacinação na maternidade, seguiram a recomendação do 
pediatra cumprindo as datas e escolheram aplicá-las em clínica privada, por "praticidade".

Beatriz e Alex: Eles estavam casados e decidiram em conjunto a melhor hora de ter filhos. Beatriz queria parto normal, entrou em trabalho de parto, mas Luan nasceu via parto cesárea pois estava virado. Ela amamentou Luan até onze meses e seguiram as recomendações do pediatra quanto às vacinas (que indicou as do calendário básico do PNI e a contra varicela). A Beatriz questionou a necessidade de dar a vacina contra varicela ao pediatra, que justificou sua importância e acabou convencendo-a. Já Alex não via motivos para questionar, e seguia fielmente o que o pediatra recomendava. Eles deram as primeiras vacinas na clínica privada, por recomendação do pediatra (por ter menos reação) e por conforto, e as seguintes na UBS.

Fernanda e Bruno: Eles estavam juntos há sete anos, e aguardaram uma situação estável para planejar a gravidez, que foi alcançada quando Bruno mudou-se do emprego em Resende para um em São Paulo e Fernanda terminou o mestrado. Fernanda desejava ter parto normal, e escolheu uma obstetra com prática e incentivo ao parto natural. Porém, Fernanda não apresentou dilatação após oito horas de bolsa rota e indução ao parto e a criança começou a apresentar taquicardia, culminando numa cesárea. Fernanda ficou muito triste no início por isso, mas ficou conformada quando viu que Gabriela nasceu bem, com saúde. Ela estava amamentando a Gabriela no momento em que foi realizada a entrevista. Optaram por não dar as vacinas na maternidade e deram as primeiras na UBS, conforme sugestão da pediatra, justificada na qualidade ser semelhante à clínica privada. Após uma reação à vacina BCG dada no posto público (febre alta que culminou em coleta de diversos exames incluindo líquor, experiência muito ruim no pronto socorro), eles repensaram e, a pedido de Fernanda, decidiram dar as demais vacinas recomendadas na clínica privada. 


\subsection{Casais que selecionaram as vacinas dos filhos}

Manuela e Nicolas: Eles tiveram a filha Ângela sem programação, quando ainda estavam cursando a faculdade, namorando e morando com os pais. Necessitaram de muita ajuda da família nesta fase. Já com o segundo filho, Gabriel, oito anos de diferença da primeira filha, foi planejado, num contexto onde já estavam casados, empregados e com boa situação financeira. Na sua primeira gestação, Manuela tentou parto normal, chegou a induzir o parto, que não progrediu e evoluiu para cesárea. Já no parto do Gabriel, ela já programou cesárea direto. Ela amamentou o Gabriel com aleitamento materno exclusivo até os seis meses durante sua licença maternidade, o que foi muito penoso para ela, que tinha o desejo de retornar ao trabalho. Eles levavam os filhos em um pediatra homeopata, que orientou muito sobre cada vacina, composição, doença que previne, o porquê etc. Baseadas na confiança e recomendações do pediatra, eles foram dando as vacinas para o Gabriel. Eles não deram a segunda dose da vacina de rotavírus, pois o filho apresentou reação adversa, com alteração do hábito intestinal, apetite e sono após a primeira dose. Atrasaram as vacinas de rotina quando o filho estiva "doentinho", não deram a da hepatite B, pois o pediatra não recomendou dá-la com menos de um ano e optaram por não dar a vacina da gripe, por insegurança com as vacinas "novas". As vacinas foram dadas no serviço público, pois o pediatra disse-lhes que era de ótima qualidade e seguro, não havendo necessidade de gastar dinheiro em uma clínica privada.

Isabel e Marcelo: Eles estavam casados há uns dois anos e meio quando tiveram a vontade de ter filhos. Tiveram o primeiro filho, Luiz, e por uma vontade e pressão maior da Isabel, um ano e meio após tiveram a Janaína. A Isabel sempre quis ter parto normal, porém o parto do Luiz foi cesárea. Após essa experiência, na segunda gravidez ela buscou um obstetra com prática em parto humanizado, tendo concretizado um parto normal como desejava. Isabel amamentou os dois filhos e assumiu todos os aspectos relacionados à saúde das crianças, pois Marcelo trabalhava por longo período fora de casa. Ela procurou três pediatras para os filhos, buscava cada profissional conforme a situação e acabou não seguindo com nenhum. Não gostava de dar medicamentos (tanto alopáticos quanto homeopáticos), não medicava na febre, preferindo uma abordagem 
natural até onde fosse possível. Isso era um motivo de discordância do casal, já que Marcelo era filho de pais médicos alopatas. Ela decidiu por vacinar os filhos, mas postergou algumas vacinas para após um ano de idade e não quis dar a segunda dose da vacina contra sarampo, caxumba e rubéola (MMR).

Cláudia e Francisco: Eles se casaram e sete meses após, Cláudia engravidou. Ela começou a se informar sobre parto normal humanizado e decidiu ter parto domiciliar com obstetra particular. No dia em que ela entrou em trabalho de parto, a médica não conseguiu chegar a tempo (pois estava em outra cidade) e quem auxiliou o parto foi uma enfermeira obstetriz. Ela ainda estava amamentando Mateus no momento em que foi realizada a entrevista. Como o parto foi em casa, eles não deram as vacinas recomendadas ao nascimento. Cláudia compartilhou informações acerca da vacinação com outras mães seguidoras do parto humanizado. Eles escolheram um pediatra humanizado que sugeriu que eles estudassem sobre as vacinas e as postergassem pelo menos até os seis meses de vida (período em que estava em casa em aleitamento materno exclusivo). Eles acataram e se questionaram sobre a necessidade de dar algumas vacinas no momento da entrada da criança na creche. Deram inicialmente a primeira dose da vacina BCG e contra pneumococo em uma UBS. Depois decidiram postergar a entrada na creche por mais seis meses e colocá-lo com um ano de idade, não dando continuidade ao calendário vacinal. Quando Mateus completou um ano, a creche pública (da Universidade onde Cláudia trabalhava) solicitou a carteira de vacinação e exigiu que a criança tivesse pelo menos a vacina Sabin (vacina oral contra poliomielite) como condicionante à matrícula da criança. Diante deste quadro, Francisco levou Mateus para tomar esta vacina.

Andreia e Rafael: Eles namoraram, moraram juntos e oficializaram o casamento no civil dois anos depois. Logo após o casamento, decidiram ter o primeiro filho. Quando Téo estava com um ano e pouco eles decidiram ter o segundo filho que culminou no nascimento da Vivian. Amamentou Téo até o nascimento de Vivian e estava amamentando Vivian no momento da entrevista. Na gravidez do Téo, Andreia teve uma ameaça de aborto. Sua obstetra do convênio indicou que ela usasse progesterona para segurar a gestação. Por intermédio de uma amiga que era doula, ela conheceu outra 
médica obstetra, praticante do parto humanizado, que sugeriu não dar a medicação e ficar em repouso quinze dias. Desde esse momento, ela passou a seguir com essa médica e Téo nasceu de parto normal, num hospital. Eles não deram as vacinas na maternidade e Andreia iniciou uma busca por informações pela internet e troca de experiência com outros pais. Eles (sobretudo Andreia) escolheram algumas vacinas e suas datas, conforme o receio de algumas doenças e medos dos efeitos adversos de algumas vacinas. Optaram por dar, na UBS, as três doses da vacina tetravalente e da pólio (esquema iniciado quando Téo estava com quatro meses); a BCG com dois anos, após o avô paterno ter tido tuberculose; e contra varicela, pois Téo tinha uma tendência de fazer feridas na pele (esta feita em clínica privada). Não deram a contra MMR por medo de sua associação com autismo e iam postergar a contra hepatite B quando os filhos estivessem adolescentes. Já a Vivian nasceu em casa, de parto natural domiciliar. Andreia estava mais segura quanto às questões das vacinas e só deu uma dose de Sabin à filha, pois tinha planos de ir para Índia a trabalho (e ela ainda estava amamentando). Quando desistiu de levar Vivian, não deu seguimento no esquema vacinal.

Sílvia e Hugo: Eles estavam juntos quando Sílvia ficou grávida, sem planejamento. Após o susto inicial, a gestação foi muito desejada. No final da gestação Sílvia teve préeclâmpsia e Antônio nasceu prematuro, e precisou ficar dezessete dias na UTI da maternidade para ganhar peso. Por causa da internação e pela ansiedade de Sílvia, o leite materno secou e Antônio recebeu aleitamento artificial. Sílvia resgatou a amamentação com ajuda de uma bomba elétrica e deu aleitamento materno exclusivo dos três meses aos seis meses, quando voltou ao trabalho. A Sílvia tem um irmão autista e, nos estudos que buscou a esse respeito, ela leu sobre a possível associação da vacina MMR com o autismo, que culminou em grande questionamento por parte dela acerca das vacinas em geral e dessa em especial, antes mesmo de ser mãe. Hugo nasceu nos EUA e sua mãe americana é homeopata que defendia a não vacinação das crianças. Hugo, antes mesmo de ser pai, achava o calendário vacinal no Brasil excessivo. Quando Antônio completou um ano de idade, próximo à entrada na creche, Sílvia sentiu a necessidade de dar algumas vacinas ao filho, convencendo Hugo, que inicialmente mostrou-se resistente. Levaram então o Antônio em uma UBS que, apesar do bom atendimento do serviço, gerou nos pais imenso desconforto, pelo fato do enfermeiro não 
ter lhes consultado sobre quais e quantas vacinas iam dar ao filho, simplesmente dando todas que eram possíveis. Por esse motivo eles demoraram em retornar para dar as doses seguintes e, na segunda vez, tiveram uma experiência negativa na sala de vacinação, com atendimento grosseiro somado à ocorrência de dor e vermelhidão no local da aplicação da vacina. Depois disso, eles não retornaram para dar seguimento ao esquema vacinal.

\subsection{Casais que não vacinaram os filhos}

Amanda e Fernando: Eles decidiram morar juntos após três meses de namoro e com um ano engravidaram sem planejamento. Amanda tinha muito medo de cirurgia, anestesia e da possibilidade de fazer cesárea. Assim, após ter passado por seis médicos, com 25 semanas de gestação encontrou uma parteira que lhe garantiu fazer parto normal. Amanda decidiu fazer parto em casa, a contragosto inicial do marido, que aos poucos foi aceitando a ideia. Após o parto, Amanda caiu e se machucou; além da dor, ela teve dificuldades no início para amamentar Mariana, ficando deprimida nos primeiros três meses, necessitando muito da ajuda do Fernando. Depois de contornada a situação, amamentou Mariana exclusivamente até 8 meses de idade. Eles escolheram uma pediatra homeopata e apenas medicavam a filha com homeopatia. Também seguiam a medicina chinesa. No tocante à vacinação, Amanda começou a pesquisar sobre o assunto durante a gestação, após sugestões advindas de uma das listas virtuais sobre parto natural e sobre vacinação. Compartilhando as informações lidas com a pediatra, Amanda decidiu inicialmente aguardar até a criança ter dois anos para começar um esquema alternativo de vacinas. Para Fernando, assim como a escolha de um parto em casa, não dar vacinas à filha causou-lhe estranheza e desconforto, porém, ele aceitou postergar o início baseado nas leituras trazidas pela esposa. Passado o período acordado, Amanda decidiu não dar as vacinas à filha por ora, com o argumento de que a criança estava saudável e tinha pouco risco de ter as doenças preveníveis pela vacinação, apesar do desejo contrário do parceiro, que achava importante a vacinação, e sentia a necessidade de dar pelo menos as "básicas". Até o momento da entrevista, a Mariana, com dois anos e meio, não tinha sido vacinada. 
Virgínia e Diogo: Eles estavam casados há dois anos quando engravidaram de Bianca e três anos após, do Lucas, ambos conforme tinham planejado. O parto foi muito traumático para Virgínia. Ela procurou um obstetra e falou do seu desejo de ter parto normal, mas o médico, no final da gestação, começou a mudar o discurso, pondo-lhe medo e, quando chegou ao redor de 40 semanas, ele marcou uma cesárea eletiva, justificada pela idade gestacional "limite" e por sua ausência, pois teria um congresso no exterior. Virgínia discutiu com ele, implorou para que ao menos ele tentasse induzir o parto. Ele induziu o parto por 12 horas, mas evoluiu para cesárea. Já o parto do Lucas foi programado para nascer em casa, mas Virgínia teve um sangramento vaginal, tendo que fazer o parto, que foi normal, no hospital. No âmbito da amamentação, Lucas é amamentado até hoje, com três anos de idade e Bianca, quando pede, também é amamentada por Virgínia. Eles vacinaram a filha até o primeiro ano e suspendeu o esquema, após Virgínia ter procurado uma médica homeopata. A experiência dolorosa acerca do parto (que a motivou a estudar sobre parto no Brasil e outras possibilidades, como o parto em casa) e a sugestão de estudo sobre vacinas da homeopata, foram decisórios para ela entrar em contato com a possibilidade de não vacinar e iniciar a problematização acerca da vacinação, buscando informações na internet sobre o assunto. Pelos estudos que ela tinha até então, ela ficou com muito medo das vacinas e estava tranquila com o modo de vida mais natural e saudável que seus filhos tinham, decidindo não vacinar Lucas e não dar mais vacinas à Bianca. Tanto a decisão inicial de parto em casa como a de não vacinação causou questionamentos e estranheza a Diogo, mas, por confiança na mulher, ele acatou as decisões e deu o seu apoio.

Paula e André: Eles estavam namorando há quatro anos, quando Paula com 23 anos engravidou de Kelly sem planejamento. Apesar de Paula desejar parto normal, com 10 semanas de gestação eles souberam que o feto tinha gastrosquise e, por esse motivo, foi indicada cesárea eletiva seguida de uma cirurgia na recém-nascida. Após 10 anos, eles programaram e engravidaram do Davi. Nesse intervalo, Paula começou a buscar na internet informações sobre parto e encontrou o movimento parto ativo e a maternidade ativa. Paula teve o Davi por um parto natural em casa. Ela relata uma mudança nos cuidados em saúde do primeiro ao segundo filho. Kelly recebeu todas as vacinas, 
vitaminas e ia ao médico regularmente. Davi, que amamentava no momento da entrevista, não tomou nenhuma medicação, nem vacina e, após as duas primeiras consultas, não foi mais ao pediatra.

Clara e Jonas: Eles estavam casados há cinco anos. Eles moraram na Austrália e lá cursaram a faculdade. Próximo do retorno ao Brasil, Clara engravidou de Marian. Por influência de uma amiga e uma postura mais natural de modo de vida, Clara já no Brasil procurou um médico humanizado e teve parto de cócoras na maternidade, nas duas gestações. Amamentou a primeira filha até a gestação da segunda, que estava sendo amamentada no momento da entrevista. $\mathrm{O}$ questionamento sobre as vacinas iniciou-se na Austrália, quando Clara assistiu a um seminário que falava dos malefícios da vacina. Desde então, Clara começou a pesquisar o assunto pela internet, dividiu suas inquietações com Jonas, sobretudo o receio sobre a composição das vacinas, a presença de metais como mercúrio e alumínio e as reações adversas. Assim, eles decidiram pela não vacinação das filhas.

Ana e Vinícius: Estavam casados há cinco anos, e planejaram a gravidez após estabilidade profissional dos dois. Ana, durante a gravidez, começou a pesquisar e conheceu a corrente do parto natural. Em conjunto analisaram os prós e contras sobre as vias e possibilidades do parto e decidiram por fazer o parto da Bruna em casa, que foi vivido como uma experiência muito especial. Já a segunda gestação, por uma alteração no ritmo cardíaco encontrada em exame intra-útero, a médica indicou realizar o parto natural no hospital. A Milena nasceu bem, mas o casal sentiu muito a diferença entre os dois partos pela desumanização do hospital. As crianças foram amamentadas e o casal decidiu postergar a vacinação e, enquanto isso, estava estudando o assunto. Como eles ainda não tinham uma posição firmada nem contra nem a favor, as crianças não tinham sido vacinadas até o momento da entrevista.

Elaine (marido Fábio não entrevistado): Elaine engravidou com 26 anos, sem planejamento, tomando anticoncepcional. Ela abandonou a sua obstetra uma semana antes de ter o parto, por indícios de que ela iria fazer cesárea. Desejando parto normal, 
ela foi ter Leonardo numa casa de parto pública. No intervalo entre o rompimento com a obstetra e o parto do primeiro filho, ela recebeu apoio e informação do grupo da maternidade ativa e, assim, não deu colírio de nitrato de prata e nem as vacinas na maternidade. Quando ela engravidou do segundo filho, ela já havia se inteirado do parto natural e fez o parto do Douglas em casa. Amamentou por mais de dois anos o primeiro filho e estava amamentando o segundo no momento da entrevista. Fábio aceitou bem a questão do parto, mas era contrário à não vacinação, sobretudo por ser advogado e do medo das consequências legais. Essa tensão no casal foi mandatória para que Elaine não permitisse a inclusão de Fábio no estudo. Ela encarou o marido, impondo em casa sua decisão acerca da não vacinação, pelo seu medo das vacinas, dos efeitos adversos e da composição, já que Elaine buscava um modo de vida mais natural, sem intervenções e medicamentos. 


\section{TOMADA DE DECISÃO SOBRE A (NÃO) VACINAÇÃO DOS FILHOS}

Esse capítulo pretende explorar o processo da tomada de decisão dos casais sobre a (não) vacinação dos filhos, englobando a compreensão do contexto, o modo como essa escolha se conformou e as principais influências na perspectiva dos casais entrevistados.

Nos casais que vacinaram os filhos, a decisão de vacinar os filhos foi caracterizada pela aceitação plena, de forma espontânea e consensual entre o casal, e estabeleceu-se sem debate ou questionamento sobre as vacinas. Não excluindo a reflexão nesse processo, esse modo foi justificado pelo grande reconhecimento dos benefícios da vacina, pela continuidade de uma tradição familiar de cuidado em saúde e pela confiança na medicina e na prescrição do pediatra.

$\mathrm{Na}$ verdade essa primeira vacina [BCG], em nenhum momento, nem eu nem ele [o marido], a gente questionou a importância das vacinas. (...) Eu tomei as vacinas na época que era criança, o Alessandro também. Parece que isso poupou a gente de vários sofrimentos, então para a gente nada mais natural do que, enfim, manter essa mesma diretriz com Larissa enfim, nunca foi uma questão (Eduarda).

Essa parte das vacinas e dos cuidados médicos foi tudo muito automático, não foi uma coisa pensada, nunca foi discutida. Por exemplo, por mim e pelo Guilherme, nós nunca 'vamos vacinar?', nunca houve esse tipo de discussão, entendeu. É automático para a gente (Helena).

O calendário vacinal seguiu as recomendações do pediatra convencional, incluindo os tipos de vacinas, as datas indicadas e o melhor local para a vacinação ${ }^{12}$. Nesse grupo, as principais influências neste processo de decisão foram o pediatra, a cultura de vacinar e a família. O peso do pediatra foi maior para alguns casais, que

\footnotetext{
12 Devido à variedade de nomenclatura sobre as linhas terapêuticas, foi optado por usar a terminologia convencional para os pediatras da linha biomédica ou alopata e não convencional, para as linhas da medicina complementar ou alternativa, quando referida pela pesquisadora. Porém, durante as análises, também serão referidos os termos usados pelos participantes, respeitando assim, a maneira como eles denominaram: pediatra, alopata, humanizado, homeopata, antroposófico, tradicional, etc.
} 
seguiram sem questionamentos as suas orientações e menor, para outros, em que ele foi decisivo para coordenar as datas do esquema vacinal, mas não alcançou o domínio da decisão sobre a vacinação, pelos valores associados às vacinas trazidos a priori.

A gente seguiu o calendário certinho. Levava a carteirinha e o médico ia avisando, a gente pregava na geladeira a próxima dose, anotava na agenda, ia lá, dava a próxima e assim foi com todas (Eduarda).

A gente já sabia disso, na verdade, das vacinas que ela toma. A gente deu uma acompanhada, uma olhada nisso um pouco antes, mas sempre houve um consenso, claro, entre eu e a Eduarda, de dar todas as vacinas (Alessandro).

A gente foi seguindo a orientação da médica, e é engraçado porque, que nem eu estava te falando antes, em nenhum momento a gente questionou ou parou para refletir sobre a orientação da médica (Fernanda).

Então eu acho que vem um pouco da educação, dos meus pais, dessa história do Zé gotinha, lembro muito bem 'ah o dia da vacinação', que isso tinha muito forte no passado, hoje acho que não tem tanto, mas no passado tinha muito isso, eu morava em Campinas e eu lembro o dia da vacinação ou mesmo aqui em são Paulo, mobilizava ai todas as escolas, tinham aquelas filas, então um pouco que isso estava no meu inconsciente, então era o dia da vacinação, então a vacinação deve ser importante. (Bruno).

Então, começou na maternidade, lá no Santa Catarina. Eu tive a Lia lá, então eu sei que algumas vacinas já começaram lá. De lá mesmo eu já saí com a carteirinha de vacinação. Fomos ao pediatra, e ele tem como algo fundamental ao trabalho dele a vacinação, então toda orientação de vacina vem dele, todos os pedidos. (...) Então assim, as decisões da vacina foi: a questão da gente mesmo, da cultura mesmo da gente, de estar vacinando, de estar prevenindo, e mais a orientação médica (Jaqueline).

Se a vacina está aí para isso, acho que temos que optar, se o 
profissional disser que tem que ser porque é importante, eu confio nele. Eu acho que se você fala que é importante, eu acho que você, se a Lia está com você e a gente confia em você plenamente, eu vou de olho fechado, vou aplicar tudo que você disser. Por que? Porque o profissional falou. Então ele nos explicou e de lá para cá tudo que ele anota, o calendário ou que não é calendário, mas porém ele acha importante, todas a gente vacina. E a gente pretende fazer isso até a última. Se o profissional falou que é necessário e precisa, vai tomar. Acho tem que ouvir os profissionais, e não o que a família fala ou que o Google mostra (Camilo).

Não foi, foi um processo que está dentro 'ah, precisa vacinar?', então vamos vacinar. (...) Na primeira consulta ele [o pediatra] já me entrega de cara a carteirinha de vacinação. Ele não fala 'você vai vacinar?', igual, ele não pergunta, então de cara já entrega a carteirinha. Então ele já entrega a carteirinha e fala 'precisa vacinar com 3 meses', então houve a influência do pediatra, e talvez seja $90 \%$ a decisão do casal. Pelo menos se ele não tivesse me entregue a carteirinha e falado 'vocês querem vacinar?', aí com certeza teria sido um assunto de discussão meu e do Guilherme. Se ele tivesse puxado essa discussão, mas não foi o caso. Ele entregou a carteirinha e já foi no piloto automático, 'tem que vacinar'. Uma doutrina dele, uma premissa, então talvez por isso a gente nunca tenha conversado. Talvez não, agora pensando com certeza foi um dos motivos. Porque pelo menos para nós pai de primeira viagem, você escuta muito o pediatra, mas muito, muito mais do que a família. Depois quando você começa a ver a linha do pediatra e a linha da família que você começa a filtrar as opiniões, mas até então, os três primeiros meses é o pediatra que você vai escutar. (...) Nunca, nunca se cogitou não vacinar, ou questionar se vai tomar vacina ou não vai (Helena).

A gente seguiu a orientação do pediatra, e normal, acho que tanto eu quanto a Helena somos muito práticos, então o que tem para tomar tem que tomar, e nem mais nem menos, mas não temos nenhuma resistência a remédio, nem também nenhum lado de hipocondríaco, de dá algo a mais, dá na medida certa (Guilherme).

O casal Beatriz e Alex, apesar da escolha de vacinar o filho ter sido unânime e 
ter a influência da opinião do pediatra, se diferenciou dos demais por apresentar distintas posturas e questionamentos entre eles, sobretudo na maneira de se relacionar com o pediatra e sobre as vacinas fora do calendário básico vigente na época da entrevista.

Beatriz: Todas as que ele tomou eu questionei o pediatra, porque, porque não, e inclusive mais de uma vez, e ele também não é daquele que sai dando, ele deu todas as padrões, a única que saia do padrão que ele pediu foi a de catapora, que eu não quis dar, e só que daí ele me convenceu a dar. (...) O Alex já é o radical que acha que tem que dar todas, e até hoje ele pergunta 'mas o Luan está totalmente vacinado? Ele tomou todas as vacinas?'.

(...) Eu estava falando para a Carolina é que eu sempre me questionei a cada vacina, a não ser as mais padrões, mas algumas que não tinham na nossa época, que era a catapora, eu perguntei 'eu tive catapora, por que eu preciso dar?'. Mas ai eu fui convencida, mas você sempre teve uma postura 'Luan está com todas as vacinas?' Eu até fiz esse questionamento, mas...

Alex: Quem sou eu para questionar também? (...)

Beatriz: Eu acho importante o questionamento, apesar de eu não concordar, eu acho importante esse questionamento, aquilo que o Alex falou, do mesmo jeito que tem a coisa imposta 'esse remédio ou essa vacina é última geração, é o lançamento, nã, nã, nã'. Começou a dar febre 'vai dá esse...', sendo que um velho resolve, então eu acho o questionamento importante, às vezes tem uma banalização. (...)

Alex: Eu não acho que o problema seja necessariamente que tenha uma parte dos médicos que ficam questionando isso, acho que faz parte desse conhecimento todo, que estão pesquisando e que estão dizendo 'olha, talvez não seja esse o caminho', acho que isso é natural. O que me espanta na verdade, pelo menos em uma primeira mirada, é começar a perceber que tem muita especulação em cima disso, de gente que não é da área, emitindo opinião, em um achismo sem nenhum fundamento e muita gente comprando essa ideia como uma coisa já empírica, consolidada, e não tem nada. Muito diferente quando um médico diz 'Olha, eu questiono tal e tal vacina, porque eu acho que esse tipo de vírus, por exemplo, não existe mais no Brasil', enfim qualquer outro tipo de questionamento, mas evidentemente que eu acho que essas coisas são um resultado de estatística, de 
comprovação, não é uma questão que você diz 'Fulano falou, eu acho que ele tem razão, e eu vou para outro caminho', eu acho um pouco arriscado, prefiro ir no certo, não vou colocar a vida em risco, não tem sentido. Acho que é isso.

A influência do pediatra também foi decisória na escolha do lugar em que iam vacinar os filhos. A decisão entre ir à Unidade Básica de Saúde (UBS) e à clínica privada foi norteada pelos argumentos do pediatra, que variaram entre a defesa do serviço público (qualidade semelhante porém sem custo, experiência de longa data, finalidade de saúde e não de lucro) e os benefícios das vacinas em clínica privada (maior conforto pelo menor número de picadas, menor reação e melhor tecnologia em algumas vacinas). Alguns pediatras sugeriram dar no público as do calendário básico e no privado as fora dele, ou dar apenas no privado as que diferiam quanto à reação, o que foi acatado pelos respectivos casais. Nenhum pediatra tinha clínica de vacinação nos seus consultórios, conforme o relato dos pais.

Agora, tem muita gente que fala assim 'ah, você não dá tudo na particular?', o próprio médico fala para mim 'se o posto dá, é confiável, dá no posto'. Então, eu dou no posto. As que não têm no posto, a gente dá particular (Jaqueline).

Nós decidimos pelas vacinas que são do posto, primeiro porque se a gente pegar, é rápido o raciocínio, a margem de que pode ter acontecido, eu não me lembro de nenhum caso divulgado na mídia, se é raro desencadear uma doença, uma paralisia, você tem que acreditar que de $100 \%, 99 \%$ é chance, e é mais fácil. Eu não só penso no posto, mas no mercado, é o que é conhecido. De repente te mostram um produto novo, que você não conhece. Então 'vamos fazer com o que nós já conhecemos', se a gente já viveu esse processo, e estamos todos aqui, então vamos seguir com a Lia, não vamos mudar. $E$ vamos acrescentar o que for preciso (Camilo).

Então, o que levou a gente a pagar, porque no posto não lembro qual era, ela era pequena, no posto tinha alguma vacina que era mais cara, que no posto não dava e que era uma que juntava várias assim e no posto até davam todas mas algumas em separado. Então, o que a gente avaliou 'coitada, vai ter que passar por três picadas, quatro picadas, quando ela pode passar por uma só, então a gente paga', e não era barato, lembro, foi 
caro 400 reais. A gente paga, mas vamos fazer essa de uma só. Então foi esse aspecto que a gente avaliou. Depois a gente descobriu que o convênio paga (Alessandro).

$\mathrm{Na}$ fala de alguns pais, o fato de ter que pagar pela vacina nas clínicas privadas foi associado à vontade parental de dar o melhor ao filho. Em um casal, Fernanda e Bruno, a pediatra recomendou dar as vacinas no posto público, mas a criança teve febre devida à vacina $\mathrm{BCG}$, que culminou numa experiência negativa de internação e realização de exames invasivos e, depois disso, eles continuaram o calendário numa clínica privada a pedido da mulher.

Foi a decisão de que assim, a gente tinha esse conhecimento de que, até assim de referências de amigos, de que a vacina, o posto de saúde, o serviço público nesse aspecto da vacinação era bom, então a gente falou 'bom porque que a gente vai pagar uma clínica particular se o público a gente tem esse serviço bom'. (...) O que aconteceu, ela tomou a BCG que dá uma reação depois de um mês, quarenta dias, para a Gabriela inflamou o braço dela e deu uma febre de 38 graus de um dia para outro. (...) Daí ela fez todo o exame de sangue, tirou líquor, eu fiquei passada, foi terrível, foi traumático, fez chapa de pulmão, toda aquela coisarada pra ver, para descartar, ela fez exame de xixi, de urina, pra descartar todas as possibilidades de uma infecção. No fim das contas, como não deu nenhum problema em nada, concluiu-se que realmente foi essa ferida da BCG. (...) E a gente inevitavelmente questionou 'putz, será que foi porque a gente deu no posto? Será que se tivesse dado em uma clínica teria dado isso?' e ai qual foi a conclusão? A partir de agora a gente só dá na clínica particular. (...) Inclusive na hora disso que eu te falei de passar do serviço público para o privado, também foi uma coisa que a gente falou 'vamos para a clínica', e ai a gente conversou com alguns amigos e parece que fica um pouco aquela sensação de se você está pagando é como se você estivesse dando e fazendo tudo que está ao seu alcance, como se ir para o serviço público fosse o caminho mais fácil. Não sei, infelizmente eu tenho um pouco esse raciocínio, apesar de no começo a gente ter tido essa postura de não achar isso de falar 'vamos, o serviço público é bom' (Fernanda).

E no posto público que nós fomos aqui na Vila Madalena, o atendimento foi muito bom, porque eu fui, eu estava presente, mas como tem fila na entrada, então a gente achou que fica 
exposto, nem sei se é verdade ou não, eu ainda acho que a qualidade é a mesma, do posto público e do posto privado, mas pelo que aconteceu a Fernanda preferiu ir no privado e eu não interferi, e ela que tá indo, então ela preferiu, enfim, então tá sendo feito desta forma. Mas seguindo toda a cartilha. Ah, um incentivo pra ir no privado é que as vacinas são, por exemplo, você tem 3 vacinas distintas e é aplicada na mesma aplicação, e no público seriam 3 picadas, então é mais dolorido pra bebê, então por isso que nós fomos no privado. (...) E também porque a gente falava 'tudo bem a gente pode pagar, então vamos'. Mas eu não tenho convicção que é melhor ou pior, eu ainda acho que o privado tem mais riscos de as vacinas estarem vencidas que no público, porque no público o pessoal deve ter seus procedimentos e são rigorosos, mais que no privado, que se vence uma vacina no privado o cara falar assim 'ah não vou jogar fora', porque sai do bolso dele, então no público não teria essa, certamente o governo tem o critério de qualidade e de segurança, mas pelo fato de ser mais dolorido pra Gabriela no público do que no privado, nós optamos pelo privado, um pouco dessa forma (Bruno).

Já nos casais que selecionaram as vacinas, o processo de tomada de decisão sobre a vacinação do filho foi muito heterogêneo. Na maioria dos casos, predominou a posição que vacinação era uma ferramenta boa de saúde. A escolha de postergar ou selecionar algumas vacinas foi balizada ou pela vivência de uma situação envolvendo a vacinação do filho, ou por um processo de problematização sobre a vacinação infantil, fundada na crítica ao calendário básico de vacinação do PNI (vacinação em idade precoce da criança e número excessivo de vacinas) e no medo de algumas vacinas específicas.

Mas a ideia era, eu acho um exagero o calendário de vacinas como é no Brasil e nesses primeiros anos de vida ainda, que o corpo é tão pequeno. Não sei, me dá a impressão que é muito veneno para o corpo sendo tão pequeno ainda, em tão pouco tempo, tão concentrado. Então, a ideia nunca foi dar o calendário completo (Sílvia).

As vivências relatadas nos depoimentos desses participantes foram: (1) Medo das vacinas "novas", recém incluídas no calendário básico do PNI; medo do efeito adverso de certas vacinas como a MMR; ou a percepção que essas vacinas protegem de doenças leves ou de fácil manejo no cuidado parental, tornando-as dispensáveis. 
Usaram como exemplo a vacina contra rotavírus e da gripe (suína e a sazonal); (2) Suspensão das doses seguintes por efeito adverso à vacina (o evento relatado pelos pais porém, são considerados leves pela biomedicina, que não contraindicaria formalmente a suspensão da vacinação); (3) Suspensão da continuidade do calendário por experiência negativa na sala de vacinação (de um serviço público); e (4) Imposição de vacinação pela creche pública, que condicionou a matrícula da criança à comprovação da vacinação de pelo menos a vacina oral contra poliomielite (Sabin).

Algumas vacinas novas a gente tenta se aprofundar um pouco mais para ver se vale a pena ou não. (...) Mas as principais a gente dá. As mais, as doenças mais perigosas aí, as mais tradicionais, a gente dá, segue a carteira. Só as mais novas que a gente avalia um pouco e com um pouco mais de profundidade. Ouve a opinião dele [pediatra] e algumas a gente não dá (Nicolas).

E teve o caso da vacina rotavírus também, que o Gabriel tomou, ele não ficou bem depois. Tem o marco do Gabriel antes da vacina rotavírus e pós-vacina rotavírus. Depois disso mexeu muito o intestino dele, que é uma das coisas que acontece com a rotavírus, mexeu muito, ele ficou preso, passou a usar supositório, ele começou a rejeitar um pouco o leite, ele mexeu muito o intestino dele e muitos gases, e muita cólica, ele começou a tomar remédio de cólica, porque ele ficou... Mexeu o intestino, mexeu tudo, o aparelho digestivo dele, né. E bom, foi a partir dali que ele começou a não dormir. E aí foi por isso que nós optamos por não dar a segunda dose, entendeu, porque foi um marco, de fato, a vacina rotavírus (Manuela).

A segunda vez que a gente foi era uma 'carniceira', a pessoa foi horrível, deu uma vacina na perna do Antônio que ficou uma semana mancando. Uma coisinha de um ano e dois meses mancando, chorando, não conseguia dormir porque não podia encostar na perna. A gente se sentiu tão destratada e tão traída pelo tratamento que foi recebido lá, e pela reação que ele teve, que depois disso a gente até tinha que voltar lá (...) e nenhum dos dois tocou no assunto, 'nós vamos interromper, a gente não...' Nem sei, até seja pior, ter começado a vacina e não terminar, mas a gente não quer fazer ele passar por isso de novo, foi muito traumático para ele essa segunda ida, assim, muito 
dolorido. Ele se sentiu muito traído também, a confiança que ele tem nos pais. Então foi um momento muito ruim para a gente, uma experiência muito ruim (Sílvia).

Daí agora que, agora que o Mateus entrou na creche, semana passada tinha uma vacina que eles exigiram, falaram 'não entra criança na creche sem tomar a Sabin'. Aí eu fui lá, no mesmo dia seguinte, eu dei a Sabin para ele (Francisco).

No tocante à problematização, o questionamento sobre as vacinas foi prévio ao processo de parentalidade no casal Sílvia e Hugo, da parte de Sílvia, por ter um irmão autista e, por parte do Hugo, por ser norte-americano filho de uma mãe homeopata e adepta da não-vacinação.

Eu já tinha dúvidas, porque eu tenho um irmão autista e tinha algumas coisas que eu já tinha lido, como possível relação de autismo com vacina, então, já tinha algum interesse com relação a isso e muitas dúvidas (Sílvia).

Eu também, minha mãe é homeopata, usa homeopatia e já tem uma perspectiva bastante anti-ortodoxa. E lá nos EUA ela já tem bastante experiência com uma postura menos ortodoxa. Eu tomei vacina, mas meus irmãos não tomaram (Hugo).

Em outros casais (Andreia e Rafael, Cláudia e Francisco), a problematização surgiu por meio de pesquisas próprias, por sugestão do pediatra ou conversas com outras mães sobre vacinação, no contexto da gestação, parto e puerpério, situado no universo do parto humanizado, que será explorado adiante. Eles optaram inicialmente em postergar a vacinação enquanto o filho estava em casa e em aleitamento materno, e iniciar algumas vacinas conforme o medo de certas doenças, processo esse que foi desencadeado pela entrada da criança na creche e situação de viagem.

O pediatra 'olha, vocês tem que decidir o que vão fazer, chegou a hora, a escola está pressionando para isso'. Aí eu perguntei para a escola como faziam nos casos que não vacinavam, e não havia nenhum caso que não tinha sido vacinado. E era uma escola, assim, supostamente um pouco mais aberta, escola construtivista, mas aqui em Santana. Santana é um bairro super conservador. Então 'bom, vai ser a única criança que não vai tomar as vacinas?', e eu comecei a pressionar muito ele [Hugo] 
para a gente vacinar, tomar algumas vacinas, porque aí eu fiquei com medo dele pegar coisas na escola. (...) Hoje eu não vacinaria o Antônio, o tipo de reação que ele teve, para o risco que teria em não vacinar eu não vacinaria (Sílvia).

Nessa heterogeneidade, as principais influências para a decisão de selecionar ou postergar as vacinas, as experiências pessoais ou a problematização vividas, foram o pediatra, as informações da internet e de conversas com pessoas da mesma geração que estavam vivenciando o mesmo momento de parentalidade.

O papel e peso do pediatra variou imensamente, para alguns ele foi decisório no norteamento das informações e recomendações do calendário vacinal e, para outros, serviu como um apoio e sustentação à decisão já tomada. Uma distinção encontrada em comparação com os casais que vacinaram foi que a maioria desses casais buscaram pediatras nomeados por eles como humanizados, homeopatas ou antroposóficos. Pelo depoimento desses casais, a relação médico-paciente pareceu ser menos hierarquizada e as conversas pareceram ser mais compartilhadas, se constituindo como um dos fatores determinantes na reflexão e questionamento sobre a vacinação infantil.

Bom, a gente gosta muito do pediatra, tem muita confiança nele, até mesmo porque ele sempre explica bem qualquer assunto, né. E na vacina também. Então, não é assim 'está na hora de dar essa vacina', não. Ele explica o porquê, que vacina que é, explica como vai ser explica tudo. (...) E acho que nós vamos continuar seguindo mesmo, enquanto a gente estiver com esse pediatra. (...) Então, assim, eu não saberia te dizer das próximas vacinas, porque não sei nada das vacinas, porque ele iria explicar no momento (Manuela).

O pediatra nosso ele tem a sua opinião e influência bastante a nossa opinião. Apesar dele não impor a opinião dele, mas ele acaba influenciando bastante, com relação a vacinas mais novas. Ele é um pouco cético, vacina de gripe, a vacina de rotavírus, por exemplo (Nicolas).

Eu acho que a palavra do pediatra teve bastante peso, mas é uma coisa que a gente já estava achando que ia fazer. Então, pesou no sentido de dizer 'ah, então o que a gente está pensando não é loucura, pode ser isso mesmo', 'é, pode'. O que mais pesou para mim foi o fato de eu conhecer outras pessoas que não vacinam, $\mathrm{e}$ 
de saber que isso não é o fim do mundo. Que vacinar não é óbvio (Cláudia).

O pediatra deu segurança para a gente. O pediatra deu plena segurança, falou que tudo bem, que ele realmente não precisa das vacinas totalmente assim, que o Mateus pode estar mais desenvolvido, pode estar mais fortinho. Tivemos apoio do pediatra. Pela segurança do pediatra também, apoiando a nossa decisão (Francisco).

Do pediatra nenhuma, vem de informações mesmo que a gente buscou, dos nossos próprios princípios assim. E aí você acaba encontrando amigos que também, que têm uma filosofia antroposófica, que nunca se vacinaram. Aí depois que você entra nesse assunto aí você descobre que vários amigos seus não são vacinados, 'nossa, achei que eu era diferente', mas não, tem um monte de gente (Rafael).

$\mathrm{Na}$ escolha do local de vacinação, a opinião do pediatra foi importante e norteadora. Predominou a orientação de fazer no serviço público (pela qualidade e ausência de custo), onde Manuela sentiu resistência por parte dos profissionais da UBS em dar apenas algumas vacinas e Sílvia e Hugo sentiram-se desconfortáveis pelo profissional ter dado o que era preconizado sem participar os pais sobre quantas ou quais vacinas eles iriam dar à criança.

O pediatra entende que na clínica pública é seguro, está ok, não precisa ser clínica particular. Ele acredita que a qualidade das vacinas é a mesma, às vezes, é até melhor na rede pública, então não precisa pagar para ter um serviço melhor. Na verdade você já tem um serviço equivalente, até melhor, sem ter que pagar, então a gente dá na clínica pública (Nicolas).

Bom, é sempre muito complicado isso, porque eu sempre dou no posto de saúde, as pessoas do posto de saúde não querem aceitar. Então eu sempre vou com pedido médico. O médico, o pediatra escreve qual a vacina que é para ser dada, e que vacina não é para ser dada. Porque chega lá no posto e as pessoas 'não, tem que dar, tem que dar porque tem que dar', 'não, mas a prescrição médica, eu não quero dar'. (...) Mas no posto sempre acontecem essas coisinhas, então, eles querem sempre dar as 
vacinas e eu falo para eles que não, que na verdade nós estamos com orientação médica. Até hoje não dei da hepatite $\mathrm{B}$ na verdade (Manuela).

Mas aí nem nos consultaram, prepararam todas, o cara ficou 'bom, mas como é que vamos fazer agora?', fez lá os cálculos dele, não nos consultou nada e deu todas as que ele achou que tinha que dar. (...) Tinha algumas, por exemplo, hepatite era uma que eu achava que não precisava dar, e que eu não gostaria que tivesse dado. Mas aí a gente viu, ele tinha preparado todas as vacinas sem consultar. (...) Chegou lá e o cara deu todas as que ele podia. Eu não queria que tivesse acontecido isso, mas ele já tinha começado a dar então 'vamos deixar dar', mas não gostei, falei 'bom, não vou criar uma encrenca aqui porque estou pedindo para o cara vacinar mas já estou vindo fora da bateria', é uma característica da minha personalidade, vou reclamar um monte depois, mas na hora não consegui reclamar com ele (Sílvia).

A maioria dos casais que não vacinaram (e alguns dos que selecionaram) passaram por um percurso semelhante, em que o questionamento e a problematização da vacinação estava contextualizada no período que envolve a gestação e o pós-parto, num processo mais amplo englobando as decisões acerca do parto. A tomada de decisão de não vacinar os filhos inicia-se com a mulher grávida ou que deseja engravidar. Essas mulheres, contrárias às práticas de saúde obstétricas atualmente predominantes no Brasil, dentre elas o excesso de cesariana e as condutas medicamentosas e invasivas nos hospitais e nas maternidades (as quais incluem, entre outras, a reanimação do recémnascido, a aplicação do colírio de nitrato de prata, da vitamina $K$ injetável e a administração das vacinas BCG e contra a hepatite B logo após o nascimento), saíram em busca de informações sobre outras possibilidades de parto.

Desejando um parto normal e humanizado, encontram uma corrente a favor do parto ativo $^{13}$, natural, humanizado ou parto domiciliar e o movimento da maternidade

\footnotetext{
${ }^{13}$ O parto ativo foi um termo criando por Janet Balaskas, no Reino Unido, nos anos 1980, em resposta à assistência obstétrica da época, em que a mulher tinha uma ação passiva e os profissionais que conduziam e decidiam todo o processo, desde a posição da mãe até os procedimentos ao bebê. Assim, o parto ativo propõe que a mulher seja ativa e protagonista desse processo, reassumindo a responsabilidade pelo seu corpo, sua experiência e seu bebê, em contraponto à apropriação da medicina do momento do parto (Fonte: <http://partoativobrasil.com.br>).
} 
ativa $^{14}$. O contato com outras mães e/ou profissionais de saúde (doulas, obstetras e pediatras que seguem a linha humanizada, homeopata ou antroposófica) adeptos desses movimentos - quem estimulam o empoderamento da mulher, o resgate do protagonismo feminino no que diz respeito ao seu corpo e sua saúde e a reapropriação do cuidado do filho da medicina para os pais - fizeram com que essas mulheres entrevistadas tivessem contato e presenciassem pessoas que não vacinaram seus filhos.

[Respondendo de onde surgiu a problematização da vacina] Não foi a maternidade, não foi a primeira vez que eu fui mãe, foi a maternidade ativa, que é uma outra filosofia. Quando fiquei grávida da Kelly 'os bebês nascem até 40 semanas', quando fiquei grávida do Pedro 'os bebês nascem quando eles estão prontos, não interessa se estão com 38, com 41 semanas'. (...) Então, na maternidade da Kelly era assim, todas as vacinas e eu não questionava. Todo mundo dá vitamina $\mathrm{C}$ com ferro, e eu não questionava. Na do Pedro assim 'não, eu não vou dar vitamina para ele porque ele não precisa, está mamando bem'. (...) É diferente, comecei a questionar muito mais com Pedro, mais por conta da informação que eu fui buscar para ter um parto natural que eu queria. Então, veio uma avalanche de informação, e aí vem tudo (Paula).

A partir do conhecimento de pessoas que não vacinaram seus filhos e da "possibilidade de não vacinar"; essas mães escolhem postergar a vacinação do filho (no hospital/maternidade ou logo após o nascimento em casa) e vão em busca de informações sobre as vacinas, recorrendo à internet (incluindo sites oficiais do Ministério da Saúde do Brasil e da Organização Mundial de Saúde, sites estrangeiros, mas também sites e redes sociais que veiculam informações de correntes antivacinação) e a livros e passaram a se relacionar virtualmente com mães e pais que não

\footnotetext{
${ }^{14}$ A maternidade ativa é uma proposta e um movimento, criado por e para mulheres, com o objetivo de tomar para si as decisões referentes ao corpo e a saúde. Iniciou-se pela busca do parto ativo, mas a ideologia se estendeu para todas as fases antes, durante e após a gestação, daí a denominação maternidade ativa. Esta corrente prega a retomada do protagonismo da mulher nos seus processos de gravidez, parto, pós-parto, amamentação e cuidado ao filho. O intuito é a mulher, se assim desejar, viver a maternidade de maneira ativa, consciente, integral e com autonomia, por meio do empoderamento (empowerment) sobre sua vida reprodutiva e sua saúde. Se baseiam em informações técnicas e evidências científicas, como diretrizes de amamentação e parto da OMS. Grupos e organizações não governamentais se propõem a oferecer e dar caminhos para a busca de informações sobre gestação, parto, amamentação e cuidados infantis e, a partir desse conhecimento, a mulher pode fazer escolhas conscientes e, finalmente, assumir responsabilidade sobre as decisões tomadas. De um modo geral há um incentivo ao parto normal e natural, à prática de doulas e parteiras, ao parto domiciliar, casas de parto, à humanização dos atendimentos hospitalares e ao aleitamento materno exclusivo até seis meses e misto até dois anos ou mais. (Fontes: <http://www.maternidadeativa.com.br/> e <http://www.partodoprincipio.com.br/>)
} 
vacinaram seus filhos. Elas então adquiriram um espectro variado de informações sobre eficácia, eficiência, efetividade, número de doses, composição, situação epidemiológica brasileira e mundial atual das doenças, virulência do agente, morbidade, mortalidade da doença, custo, indústria farmacêutica que produz tal vacina, calendário vacinal brasileiro, países que optaram e que rejeitaram tal vacina no seu calendário básico, variações de data de início ou número de doses em esquemas vacinais de outros países e os efeitos adversos a curto, médio e longo prazo. De posse de informações em graus variados de aprofundamento, quantidade e qualidade dos dados, e apoiadas pela postura de pediatras que colocam que a decisão e escolha sobre vacinação e sobre o cuidado infantil são de responsabilidade e domínio dos pais, essas mães dividem com seus parceiros os medos e as angústias em vacinar os filhos e, mediante uma negociação, por vezes fácil, por vezes tensa entre o casal, decidem “em conjunto” pela não vacinação.

Assim, para a maioria dos participantes, não houve um questionamento isolado da vacinação em si, nem prévio a este processo (exceto com a Clara), antes da maternidade/paternidade. Isso veio junto com a contextualização do parto ativo, natural, humanizado e a crítica às práticas de saúde de forma mais ampla no processo saúdedoença-intervenção materno-infantil.

Foi assim, na gravidez eu comecei a pesquisar um pouco. E aí eu lembro que em uma das listas de parto tinha algumas mulheres que falaram assim 'ah, a vacinação não é necessária', elas falaram que não vacinavam. Para mim eu sempre aprendi que tinha que vacinar. E ela falou que não vacinava. (...) Eu perguntei 'mas como assim não vacina? Pode não vacinar? Por que você não vacina?' Eu nunca tinha pensado nisso, em vacinação. Aí ela indicou a lista da vacina e me indicaram aquele livrinho, 'Vacinar sim ou não' (Amanda).

$\mathrm{E}$ aí tem aquele negocinho, aquela vitamina $\mathrm{K}$ que toma e não sei o que, coisas que sendo em casa [o parto] a gente ia ter que ver como ia fazer, se não ia... Então, a relação é total com o processo do parto, como sendo um opcional, que é aplicada muitas vezes no hospital, se a gente queria ou não. E aí tinha alguns exames, havia alguns exames que a gente não queria que fizesse, tipo uma coisa no olhinho da criança, que provoca uma conjuntivite química e não sei o que. E as vacinas entram naturalmente em cima dessas coisas. Então, para nós é quase 
que uma extensão do problema do parto (Vinícius).

Eu simplesmente dava o que todo mundo dava. E é engraçado porque, se eu tivesse ouvido o que eu ouvi sobre vacina antes do parto, talvez eu teria a mesma postura que muita gente tem hoje. Ou ia falar 'isso é papo de doido', só que como eu tive que rever os meus conceitos com relação ao parto, 'espera aí, se existe uma outra realidade de obstetrícia, diferente do que se vê hoje em dia, por que não pode ter também em relação à vacina?' E aí parei para ouvir o que ela [pediatra] me falou. Senão teria fechado o ouvido, entendeu. E aí eu fui pesquisar, então não foi uma decisão da pediatra. Foi uma sugestão de pesquisa e aí eu fui atrás. Ela foi o ponto de partida e eu comecei a estudar (Virgínia).

Em apenas uma entrevistada desse grupo, Clara, o questionamento sobre a vacinação é anterior à gestação e originou de informações anti-vacinação que Clara teve acesso em um seminário da faculdade na Austrália, na época em que cursava a faculdade de nutrição neste país. Essa vivência de Clara no exterior ilustra a presença de posturas e opiniões anti-vacinação fora do Brasil, disseminadas mesmo em ambientes de ensino (Offit, 2008; Plotkin et al., 2008).

Começou bem antes de ter filho. Foi um seminário que eu fui, quando estava estudando, e eu não lembro a pessoa que estava falando, mas era uma senhora já, ela tem livro até. Eu não tenho o livro comigo aqui. Ela era bem contra a vacinação na verdade, totalmente contra, botou todos os fatos, lá na frente falou, falou sobre vacinação e eu já fiquei assim 'nossa, por que isso? por que a gente tem que fazer isso?'(...) E lá eu comecei a pensar. Aí fiz o trabalho na faculdade, aí pensei, falei 'nossa, vou estudar mais!' (Clara).

As principais influências nesse grupo variaram conforme o sexo dos participantes. Para essas mulheres, as maiores influências foram as informações que buscaram ou que chegaram até elas - por influência ou não dos pediatras - por site, livros, grupos virtuais e também discussões com outras mães da mesma geração e em um mesmo momento de vida que não vacinaram seus filhos. Para esses homens, as maiores influências foram suas esposas, que trouxeram a eles as informações sobre as vacinas.

Todos os casais desse grupo buscaram um pediatra não convencional, nomeados 
por eles por profissionais humanizados, homeopatas, antroposóficos e da medicina chinesa. O papel do pediatra neste processo revelou-se diverso: foi ausente para algumas mães ou para o casal, por já terem decidido não vacinar antes de saber a opinião do pediatra; foi o ponto de partida para que as mães buscassem a informação, assumindo mais uma função norteadora do que influenciando diretamente nas escolhas de dar ou não cada vacina; e foi importante como apoio, dando segurança à decisão tomada por eles.

O posicionamento dos médicos, embora não seja uma recomendação médica, mas um apoio. (...) E essas leituras influenciaram bastante, esse livro, elas influenciaram a gente. É isso (Ana).

[Reproduzindo a suposta fala do médico] 'É questão de vocês, se quiser vacinar, vacina. Se não quiser vacinar, não vacina' Então, não foi nenhum pediatra que chegou para a gente e falou 'oh, não vacina, por causa disso...' (Jonas).

Primeiro foi a médica. Não que ela orientou a não vacinar. Ela orientou que não havia necessidade se a gente não quisesse (Fernando).

No tocante ao processo de escolha pela (não) vacinação, destaca-se em primeiro lugar, o espectro que vai desde a aceitação plena da vacinação, nos casais que vacinaram, até a sua negação, passando por diferentes matizes de questionamento entre os casais que selecionaram e não vacinaram os filhos, refletindo distinções no manejo e modo de se relacionar com a saúde infantil.

A diferença entre as posturas de aceitação plena à questionadora, assim como a diversidade no peso do pediatra nesse processo, foram semelhantes aos relatados em estudos internacionais, que visaram identificar as atitudes e características de pais perante a vacinação dos filhos (Benin et al., 2006; Leask et al., 2012). O grupo denominado "unquestioning acceptors" (Leask et al., 2012) ou "vacinadores aceitantes" (Benin et al., 2006) foi caracterizado por ter bom relacionamento com o pediatra convencional, confiança em suas deliberações e ter menos conhecimento detalhado sobre vacinação. Já o grupo "vacinadores tardios", que se assemelha aos casais que selecionaram neste estudo, predominou o questionamento do pediatra em diferentes 
graus e a busca também de outros meios para adquirir a informação. $O$ grupo "rejecters" (que se aproximam dos casais não vacinadores) foi descrito como menos propenso a procurar a opinião do pediatra convencional e buscou outros profissionais como homeopatas, naturopatas e demais fontes como livros, sites e revistas sobre maternidade. Vasconcellos-Silva e Castiel (2010) descreveram o perfil das famílias norte-americanas e europeias que optaram por não vacinar seus filhos, em que apresentam similaridades com esses casais do presente estudo.

As condições de vulnerabilidade incluem os filhos (sexo masculino predomina); de mães casadas; com alto nível de escolaridade; acesso à internet; vivendo em vizinhanças com renda anual acima da média nacional americana; residente em estados com exclusões de ilicitude da lei de vacinação escolar por motivos filosóficos; e que expressa sérias preocupações acerca dos efeitos colaterais das vacinas. Além disso, tais famílias admitem que os médicos exerçam pouca ou nenhuma influência sobre as decisões nesse campo, o que é condizente com os estudos que indicam a internet como grande influenciadora nas opiniões - acima até dos profissionais de saúde (Vasconcellos-Silva; Castiel, 2010: s/n).

A aceitação plena entre os que vacinaram pode ser lida como expressão da legitimidade que conferem aos avanços da tecnologia médica no campo da vacinação e da grande confiança no pediatra que acompanha os filhos. Neste contexto, vacinar os filhos faz parte de um processo quase introjetado e em sintonia com os posicionamentos da saúde pública brasileira, reconhecido pelos pais como cuidado à saúde infantil e responsabilidade parental. Por sua vez, o questionamento dos casais que selecionaram e que não vacinaram, trouxe a problematização de uma intervenção validada e consagrada no meio médico-científico, e sua associação com o cuidado infantil, remodelando a relação de certas pessoas ou grupos com essa prática de saúde. Essa diversidade de postura revela tensões e confluências nas interações de pessoas pertencentes à mesma camada social com os saberes e as práticas médicas na contemporaneidade.

Outro ponto importante, que aproximou os diferentes casais ao invés de distingui-los, foi o trajeto pelo qual a tomada de decisão em (não) vacinar os filhos foi sendo construída. No campo de possibilidades da sociedade complexa contemporânea descrita por Velho (1987, 1994), esses casais foram arquitetando o cuidado do filho por meio de influências de diversas fontes, fatores e interlocutores, como médicos (alopatas, humanizados, homeopatas, antroposóficos), outros profissionais de saúde, família, 
informações da internet, mídia, livros, por conversa com pessoas do seu círculo social etc. A pluralidade característica da contemporaneidade sustenta os diversos trânsitos, incluindo a gama de trajetos na área da saúde infantil. Além disso, a maioria dos casais, independentemente da escolha acerca da vacinação dos filhos, buscaram sentido e justificativa de suas escolhas norteadas pela mesma racionalidade, a científica, ou seja, guiaram-se e respaldaram-se pela legitimidade da ciência. Por terem escolhido um caminho contra hegemônico, essa característica se sobressaiu nos casais que não vacinaram, que buscaram a legitimação do conhecimento científico, e dos oficiantes desse conhecimento - por meio do apoio dos médicos - para justificar o parto em casa, não dar os procedimentos preconizados no recém-nascido, não dar a vacinação, assim por diante.

Além disso, como salientou Velho (1987, 1994), um projeto vivido como individual, por mais que envolva a subjetividade, também faz parte de um projeto social ou coletivo, quando ele é captado, expresso e compartilhado por um grupo de pessoas. A condição para que um projeto exista, na visão do autor, é ele ser reconhecido pelo outro. Isso ficou evidente nos depoimentos dos pais que não vacinaram, em que esse projeto só se materializou após eles encontrarem pessoas que não haviam vacinado os filhos e saber que isso era "possível". Apesar dele ser vivido como um projeto individual, ele se mostrou como parte de um projeto coletivo, com perfis estabelecidos oriundos de "tribos" ou grupos como a maternidade ativa, o parto ativo, humanizado etc. Essa constatação, porém, não desindividualiza o processo, cuja singularidade se expressa sobretudo nas diferentes maneiras de se vivenciar esses projetos.

No caso dos pais que não vacinaram e alguns dos que selecionaram, o processo de tomada de decisão sobre vacinação infantil ao revés da prática normativa hegemônica, foi reflexo de reações tanto no âmbito das práticas de saúde, quanto de processos contemporâneos mais amplos. Os achados desse estudo evidenciaram dois importantes aspectos que culminaram na problematização da vacinação infantil: um relativo ao contexto, em que a reflexão sobre a vacina ocorreu ativa $\mathrm{e}$ preponderantemente pela mulher, num cenário reativo às práticas atuais da saúde materno-infantil, em especial, às referentes à assistência ao parto; e outro, que diz respeito ao peso das informações de saúde na remodelação das relações entre 
profissionais de saúde e indivíduos/grupos. São esses aspectos que serão discutidos na sequência.

\subsection{A problematização da vacina no contexto do parto humanizado}

A maioria dos casais que não vacinaram não tinham questionamentos a priori ou específico contra vacinação antes do processo que envolvia o período da gestação e do parto. O contexto do parto humanizado (também chamado pelos participantes de natural, ativo, em casa ou domiciliar, de cócoras, normal, vaginal, na banheira) no questionamento de condutas obstétricas, médicas e hospitalares, sobretudo as invasivas, foi imperativo.

A reatividade do movimento do parto humanizado frente às práticas de parto hegemônicas no Brasil - que por sua vez repercute na escolha pela (não) vacinação infantil - está imersa no processo de medicalização do corpo feminino (Vieira, 2008). A partir do século XIX, a medicina começa a apropriar-se de aspectos cotidianos e fisiológicos da vida humana conformando-os em normas sociais. A medicina passa a acessar as vias públicas, as sociedades e as famílias por meio do discurso da higiene. A medicalização do corpo feminino, à semelhança da medicalização da infância e da institucionalização da pediatria e puericultura, foi consolidada na meta de diminuir a mortalidade infantil, na valorização da infância como o futuro da nação e pela validação científica. Se atribuiu e redefiniu o papel da mulher na sociedade e na vida doméstica, e a maternidade passa a assumir uma função político-social. Para tanto, o discurso disciplinador médico-higienista resgata a dimensão biológica do ato de parir e amamentar, em que se naturaliza a reprodução e lactação sem considerar que a vivência da maternidade está mediada também pela dimensão sociocultural. (Vieira, 2008; Freire, 2009; Nunes, 2011).

A obstetrícia, palavra "originada do latim obstetricum, em que obs significa 'estar diante de' e tetricum significa 'tétrico, mórbido'" (Vieira, 2008: 50; grifos da autora) se forma como uma disciplina por meio do encontro do conhecimento técnico cirúrgico, de propriedade masculina, com o processo do parto, cujo auxílio do partejar era até então exercido por parteiras mulheres. O deslocamento dos saberes e práticas das 
parteiras para os médicos resultou na patologização e hospitalização do parto que, embasado cientificamente, regulamenta situações de (a)normalidade (Vieira, 2008). A passagem do parto domiciliar por parteira para o parto hospitalizado pelo médico, sofreu inicialmente resistência social, sobretudo pelo medo da morte (elevada mortalidade materna por febre puerperal), pelo olhar masculino nas áreas íntimas das mulheres e pelo uso de novos instrumentos como o fórceps (Vieira, 2008).

No processo de consolidação da apropriação do parto pelos médicos, a obstetrícia cirúrgica ressignifica o parto como um processo fisiopatológico que causa risco e sofrimento à mulher e sua ação masculina, solidária e científica, vem intervir diante desse padecimento. E, "uma vez que o parto é descrito como um evento medonho, a obstetrícia médica oferece um apagamento da experiência" (Diniz, 2005: 628; grifo da autora). Na segunda metade do século XX, o modelo hegemônico de parto foi o hospitalar, onde a mulher era submetida a diversos procedimentos de forma sistemática e de rotina como ausência do acompanhante, episiotomia (corte cirúrgico da musculatura da vulva e vagina), tricotomia (corte de pelos), amniotomia (ruptura intencional da bolsa amniótica), enema (lavagem intestinal), jejum entre outros. Paradoxalmente ao avanço científico-tecnológico, esse modelo gerava elevado índice de morbimortalidade, além de causar sofrimento físico e emocional à mulher, despersonificando-a em sua vivência de partejar (Diniz, 2005).

O campo da obstetrícia, por sua vez, defende que a via preferencial e desejável é o parto normal, mas reconhece os benefícios do parto cesárea em situações bem estabelecidas, que conforme a recomendação da OMS, deveria ocupar uma proporção ao redor de $15 \%$ dos partos (Tesser et al, 2011). A cesariana é uma intervenção médicaobstétrica cirúrgica que foi sendo aperfeiçoada tecnicamente ao longo do tempo. Nesse processo, também se avançaram os conhecimentos sobre as melhores indicações dessa ferramenta médica, levando em consideração as situações de intercorrências patológicas em que essa via de parto levaria a uma menor morbimortalidade à mãe e/ou ao feto em relação ao parto vaginal. As recomendações médicas para o parto cesárea são indicadas de forma eletiva ou de urgência, principalmente nos seguintes eventos: feto em apresentação pélvica ou apresentação transversa persistente, sofrimento fetal agudo, macrossomia (fetos com peso igual ou superior a 4500g), placenta prévia oclusiva, descolamento prematuro de placenta com feto vivo ou hemorragia anteparto, doença 
hipertensiva específica da gravidez, duas ou mais cesáreas prévias, alguns partos gemelares (sobretudo quando o primeiro feto tem apresentação pélvica e na trigemelaridade ou mais), fetos com algumas malformações congênitas, mulheres com lesão por herpes vaginal ativa no momento do parto e mães infectadas pelo HIV (Martins-Costa et al, 2002; Cabral et al. 2003).

Apesar dessas indicações, assistiu-se no Brasil um progressivo excesso de cesarianas, de causa multifatorial, que incluem aspectos relativos às mulheres, aos médicos, ao modelo de assistência ao parto e ao âmbito sociocultural (Tesser et al., 2011; Victora et al. 2011). Dados de estudos entre 2007 a 2009 mostraram que quase $50 \%$ dos partos no Brasil foram cesáreas, e destes, 35\% foram no SUS e ao redor de 80$85 \%$ no setor privado, sendo mais prevalente em mulheres de maior nível socioeconômico, maior escolaridade e mulheres brancas (Tesser et al., 2011; Victora et al. 2011). Nesse cenário, na concepção biomédica e da OMS, o vilão não é a cesárea em si, que quando bem indicada reduz a morbimortalidade materno-infantil, mas sim, seu uso abusivo ou fora dos critérios estabelecidos.

Como resposta a essa prática hegemônica medicalizada e hospitalocêntrica, a partir das décadas de 1970/80 inicia-se um movimento internacional (com destaque nos EUA, França e Inglaterra) e nacional, com o apoio posterior da OMS, que no Brasil foi denominado humanização do parto. Ele visou melhorar a qualidade das relações entre a parturiente e seus cuidadores, a liberdade de escolha da posição de parto pela mulher, a presença de um acompanhante à escolha da mulher, a abolição de práticas danosas e desnecessárias (como tricotomia, enema, jejum), o uso adequado e cauteloso de indução ao parto, cesárea, episiotomia, amniotomia e fórceps; além do estímulo ao parto normal e a amamentação imediatamente após o parto e o alojamento conjunto. No âmbito do significado, esse movimento procurou transferir a conotação do parto como um evento fisiopatológico e da mulher como vítima para algo fisiológico e natural, protagonizado pela mulher e não pelo médico, atrelado a sentidos positivos ao ato de partejar (Tornquist, 2002; Diniz, 2005).

$\mathrm{O}$ ativismo e movimento do parto humanizado e da maternidade ativa no Brasil mostra muita semelhança com o que Badinter (2011) descreveu na França como maternidade ecológica. Tal movimento é um resgate, por algumas mulheres incluindo as novas mães, a volta ao natural e à naturalização biológica da mulher como mãe e 
amamentadora, em que se recupera o culto ao instinto materno. Tal corrente foi influenciada pelo movimento ecológico e por uma linha que atribui valores negativos ao que é químico e artificial oriundo do avanço científico-tecnológico, que ameaçam o meio ambiente e geram danos à natureza. Houve, paralelamente, uma corrente feminista, o maternalismo, contrária à postura da mulher negar ou abafar suas características de gestora e nutriz para se igualar aos homens e propôs, justamente na diferença calcada na essência biológica feminina, o argumento de reivindicação político e moral, ou seja, é por meio da maternidade que a mulher pode alcançar sua felicidade e transformar o mundo, gerando e cuidando de seres cada vez melhores. Além das ideologias ecológicas e maternalistas, houve uma contra resposta às violências institucionais hospitalares, como o abuso de cesarianas, episiotomias e partos apressados apenas pelo conforto do obstetra.

Na origem dessa tendência, está a rejeição por parte de algumas mulheres das técnicas hospitalares vividas como desapossamento do corpo e, logo, da maternidade. Descontentes com a rigidez das regras do hospital, exasperadas com o autoritarismo do médico onipotente que as tratava como crianças, e convencidas que o nascimento é um fenômeno natural e não um problema médico, algumas começaram, desde os anos 1970, a parir em casa (Badinter, 2011: 50).

O movimento pelo parto humanizado no Brasil passou a se relacionar, como aponta Diniz, "a partir do fim da década de 1990, virtualmente através de listas eletrônicas como Parto Natural, Amigas do Parto, Rehuna, Materna, Parto Nosso, Mães Empoderadas, entre outras, a maioria criada por consumidoras organizadas de classe média" (2005:631). Tornquist (2002) também aponta que os ideais do parto humanizado no Brasil foram abraçados sobretudo pela camada média intelectualizada, o que condiz com o perfil dos casais e com os dados empíricos desse estudo.

Nos casais que não vacinaram e alguns dos que selecionaram, houve uma resistência inicial por parte dos homens em aceitar o parto humanizado, sobretudo o domiciliar. Isso reforça o protagonismo das mulheres não só no engajamento ao movimento, mas nas decisões em saúde no ambiente familiar, tanto do parto, quanto para a escolha da (não) vacinação do filho.

No começo quando ela falou 'vamos ter um nenê em casa', para mim foi meio radicalismo. Eu falei 'não, você está maluca, com o monte de coisas que a gente tem para a questão de hospital, de segurança, de assepsia', 'uma evolução que é para o mal', ela me 
mostrando. A gente fez o curso, durou acho que um sábado inteiro e ela foi me alimentando das coisas e eu fui digerindo, digerindo, e eu falei 'não, beleza, nós vamos ter'. Eu falei que queria no hospital e ela falou 'não, vamos fazer em casa' (Diogo).

Ah, a gente acabou resolvendo conversando mesmo. Conversando, não só com ela como com a Lourdes [doula] também, me mostrou alguns livros, algumas coisas, fui nas reuniões no Gama e tal, acabou abrindo um pouco a cabeça a respeito. Mas no começo realmente, a ideia que eu sempre tive é que vai para o hospital e é no hospital que nasce, nunca tinha nem pensado em ter em casa, dessa forma que foi (Fernando).

Aí para nós tem tudo a ver esse negócio com o negócio do parto natural e tudo mais, porque ela começou a estudar essas coisas, já grávida. Inicialmente parecia uma coisa totalmente louca. Quando eu vi a primeira vez, vi em uma reunião aqui, vi uma mãe descrevendo como tinha tido o filho em casa e tudo mais, que foi ter o filho, deitou na cama, que a cama estava toda suja de sangue, não sei o que e contando tudo aquilo com a maior tranquilidade. Eu pensei 'nossa, isso é uma loucura'. Mas aí eu fui estudando o assunto e tal, a questão das cesáreas e tudo mais e você vê que tem alguma coisa errada em tudo isso (Vinícius).

A violência à mulher descrita em estudos sobre o modelo hegemônico de parto no Brasil (Tornquist, 2002; Diniz, 2005; Vieira, 2008), foi vivida pela Virgínia, fato esse decisivo para todas as decisões futuras sobre a saúde dela, dos filhos e da família, incluindo a escolha pela não vacinação.

$\mathrm{O}$ da Bianca foi muito ruim, porque eu queria um parto normal, só que eu não sabia muito, na realidade, da obstetrícia no Brasil, infelizmente e não sabia que apesar de ser muito divulgado que parto normal é bom, na verdade não é tão assim nos fatos. No final da minha gestação o médico falou para mim que faria um parto normal, que me acompanharia no parto normal que eu desejava e no final ele começou a me colocar medo, de que ia passar da hora e eu sabia que a gestação poderia chegar até 42 semanas e fiquei forçando o parto normal. (...) Isso foi muito difícil para mim, porque ele no final ele falou 'depois de tal dia não pode, então vamos marcar a cesárea um dia antes', e aí eu 
liguei para ele, eu falei 'mas você vai me enfiar a faca, sabendo que eu queria parto normal? Eu não vou conseguir ir para o hospital com uma cesárea agendada', aí ele falou 'ah, mas o que você quer que eu faça?', e eu falei 'você não quer tentar nem induzir?' Eu mudaria de médico hoje, mas aquela Virgínia daquela época achou que a indução seria a minha última esperança. (...) Aí eu fiquei em indução quase 12 horas, (...) às 17 horas a obstetriz que estava comigo falou 'não vai', e aí eu chorei... (...) Essas horas das 17 horas até a hora que Bianca nasceu, foram a mais desumana possível. Essa hora que eu aprendi como é desumano o parto no Brasil, infelizmente. O atendimento não é atencioso, e aí Bianca nasceu, e eu sequer sabia de todos os procedimentos com as crianças. Me senti roubada. Apesar de hoje entender que aquilo foi extremamente importante para o meu crescimento e que eu não fui roubada, eu me deixei roubar, é diferente, mas antes o sentimento era de roubo. Aí depois tomei conhecimento de todos os procedimentos com Bianca, que foram decisivos para eu tentar outro parto com o Lucas, então de fato o parto do Lucas começou na mesa de cirurgia da Bianca. Porque eu me senti maltratada, desrespeitada, não sabia que uma cesárea ficava com o braço preso, a luz imensa, durante a cirurgia eles ficavam fazendo piadinha de galinha queimada, só coisa ruim. (...) Através dessa decepção, em vez de ficar prostrada, eu comecei a estudar muito. Nessa hora eu tomei as rédeas de minha saúde. Então, eu precisei ser roubada para poder resgatar. (...) Esse tempo todo entre o nascimento da Bianca e do Lucas, eu fui crescendo e foi quando comecei a estudar sobre vacina e sobre todos os cuidados com a criança e o bebê (Virgínia).

O casal Ana e Vinícius viveu a experiência de um primeiro parto em casa e um segundo no hospital - pois o feto apresentou uma alteração cardíaca - e eles relataram nos seus depoimentos a desumanização sentida pelos protocolos do hospital.

No hospital é super difícil. Porque depois que você está acostumado com a intimidade, no hospital é quase impossível. Porque as pessoas ficam entrando, mesmo sendo na salinha do parto humanizado, lá no São Luiz, é tudo esquisito, é despersonalizado. Você chega e já tem que trocar a roupa, põe aquela roupa de prisioneiro, tudo isso parece um ritual de despersonalização. (...) E toda hora entrava uma enfermeira, entendeu, e perguntando coisas. Só parou de entrar depois que a gente pediu, nós falamos para a médica, mas de fato era meio 
complicado e tal. (...) O controle continua na mão do sistema, as pessoas vêm a toda hora para ver o que está acontecendo, ou para coisas inúteis como pegar uma luva e não sei o que, mas aquilo mantém o controle na mão da estrutura. (...) A enfermeira, ela com aquele procedimento, você vê que ela não quer responder nada, me chamando de 'papai'. Eu queria enforcá-la, porque não é minha filha. Aquele 'papai' comercial que elas usam, sabe (Vinícius).

O movimento pelo parto humanizado e a proposta da maternidade ativa se legitimam no contexto dos direitos reprodutivos e sexuais das mulheres mas, por sua vez, são presas de suas próprias armadilhas, como salienta Tornquist (2003: S426): “O ideário do parto humanizado, portanto, contém paradoxos: de um lado, advoga os direitos das mulheres no momento do parto, de outro, parece estar desatento às diferenças socioculturais entre estas mulheres." $\mathrm{O}$ empoderamento feminino num discurso centrado na sua condição biológica, onde a mulher reassume o domínio de seu corpo - que é capaz de gestar, parir e amamentar-, reforça a corrente essencialista que naturaliza as funções sexuais e reprodutivas femininas, enfraquecendo a dimensão simbólica e a singularização que tanto pregam (Tornquist, 2002, 2003).

Além disso, se constrói nessas mulheres um ideário de um "belo parto" $\left(\right.$ Fonseca ${ }^{15}$ ), com normatizações e um modelo a se seguir (ser de cócoras ou na banheira, ter doula etc.), que nem sempre é alcançado pelas mulheres, podendo gerar imensa frustração e culpabilização pelo fracasso.

Embora essa 'mulher moderna' seja vista agora como sujeito de suas escolhas - inclusive a maternidade - ela novamente se vê diante de prescrições ditadas por saberes científicos, que a farão escolher o que é o melhor para o bebê, e de uma celebração do parto ideal, este não raro muito distante do campo de escolha e de possibilidade de boa parte das mulheres que dão à luz (Tornquist, 2002: 490).

Essa padronização também foi encontrada nos depoimentos que revelaram a relação entre parto humanizado e a escolha pela não vacinação infantil. $O$ parto humanizado e a maternidade ativa se constroem com premissas e regras, por vezes

\footnotetext{
${ }^{15}$ Fonseca C. Anatomia de uma Maternidade. Pesquisadores, profissionais de saúde e pacientes num quadro hospitalar. Tradução de texto publicado em 1992 "quelques réflexions ethnologiques sur une maternité française." Ethnos (Association pour l'Anthropologie Médicale), LeHavre, França. Disponível em português em: <http://claudialwfonseca.webnode.com.br/publica\%C3\%A7\%C3\%B5es/mulher-efamilia/>
} 
generalizantes e rígidas, podendo abafar a singularidade veiculada nas suas metas. A proposta de um parto em casa, o estímulo ao aleitamento materno e a ausência de qualquer procedimento ou medicamento (como uso de vitamina K, o colírio de prata) e, em especial, a incitação pela problematização das vacinas, podem ser experimentados com diferentes graus de coerção por esse círculo social, que por um lado, se relativiza o discurso de um protagonismo em que as escolhas são individuais e singularizadas e, por outro lado, conforma uma normatização à semelhança, porém ao avesso, do modelo hegemônico biomédico e hospitalocêntrico que pretendem combater.

\subsection{A informação em saúde como divisor de águas}

A busca, o acesso à informação e todo o processo que foi desencadeado $a$ posteriori, encontrados nos dados empíricos desde estudo por esses casais, estão de acordo com a hipótese de Waldman (2008), que apontou ser a informação um novo fator associado à desigualdade em saúde, e que justificaria a tendência a uma queda na adesão à vacinação infantil em famílias mais ricas e de alta escolaridade em São Paulo, em comparação às camadas mais populares, cujo principal fator de desigualdade está relacionado ao acesso aos serviços de saúde.

As informações sobre as vacinas, desde situação e gravidade das doenças de que elas protegem, composição, efeitos adversos, calendário vacinal do Brasil e de outros países, entre outras, foram o grande divisor de água para a mudança paradigmática frente à tomada de decisão em não vacinar. Para os casais que não vacinaram e alguns dos que selecionaram, as informações assumiram um lugar decisório e de respaldo da tomada de decisão, cuja escolha baseou-se justamente no conhecimento e aprofundamento sobre o assunto, um ato pensado, refletido e não uma postura infundada ou de aceitar tudo que é passado pelo médico.

Daí eu fui atrás, antes de tomar a minha decisão eu fui atrás de estudos, fui atrás de informação, do próprio Ministério da Saúde, em relação às vacinas, como elas funcionam, como são feitas, quais são os componentes da vacina. (...) Eu não sei se eu sou corajosa, né? Eu só decidi, mas não é uma questão de coragem. Não é uma questão nem de coragem, nem de loucura,

nem de nada. É uma questão só de informação, como tudo, 
como tudo. É você se informar e tomar uma decisão (Clara).

Foram pessoas, primeiro, falando, sobre os malefícios das vacinas, e os textos científicos que eu tive acesso, e que eu, todo mundo tem acesso, é só ir no Google. Todo mundo sabe o capítulo da novela quando quer. Então, do mesmo jeito, você vai lá na internet, pesquisa e você consegue um monte de coisas. Só que ninguém vai atrás, a verdade é essa. A gente não procura informação, quando a gente quer você vai achar um monte de coisas. Então, eu comecei a ouvir mais as pessoas, a experiência das pessoas e aí conforme eu ouvia, eu ia pesquisar, para ver se aquilo tinha embasamento científico que eu pudesse realmente avaliar e dizer 'não, é verdade, faz sentido' (Paula).

A gente deu uma lida, estudou também, para tomar essa decisão. Não foi tomada assim de 'ah, não vamos vacinar e pronto'. A gente estudou bastante a respeito. Conversou com gente que não vacinou também, conversou com médicos que orientam a vacinar e que não orientam, então a gente acabou resolvendo assumir isso aí, e não expor ela a esse tipo de situação tão pequena (Fernando).

O processo de busca pelas informações sobre vacinas ocorreu ativamente pelas mulheres, em que a curiosidade inicial foi desencadeada após contato com outras mulheres que não vacinaram seus filhos (presencialmente ou por meio de grupos virtuais) ou por indicação de algum profissional da área da saúde (médicos ou obstetrizes humanizados, antroposóficos ou homeopatas, favoráveis ao parto natural, humanizado, ativo). Assim, para a maioria dos homens, a aquisição de conhecimento sobre vacinação foi indireto, cuja fonte era a pesquisa oriunda de sua companheira. Com exceção de um casal, Ana e Vinícius, em que esse processo de busca e de análise crítica das informações foi mais igualitário e conjunto, não foi relatado um interesse inicial ou uma postura proativa dos homens em irem atrás de literatura sobre vacinação para confrontá-la com a encontrada por sua mulher. A maioria se sentiu satisfeito com o material trazido pela parceira e alguns nem chegaram a lê-lo, alegando confiança à esposa.

[Falando sobre os riscos da vacina] $\mathrm{E}$ muitas pessoas não sabem disso. Elas não têm a informação. E eu não tinha, eu fui ter porque a minha esposa, eu dei sorte, ela estava estudando e tudo 
que ela estudou eu sempre ia perguntar. Sempre ela vinha e toca nisso no jantar, a gente sempre conversou sobre isso (Jonas).

Não é uma coisa que eu fale e ele segue. Eu leio, passo alguns, as coisas mais importantes, e aí depois a gente discute. Ás vezes demora muito para ele ler determinado assunto, mas eu mando várias coisas do mesmo assunto e um dia ele fala 'ela não vai desistir', e ele lê. (ri). E aí lê alguma coisa e acaba concordando ou não e a gente vai fazendo assim (Virgínia).

Mas a informação que a Virgínia passa, transmite para mim, porque ela tem tempo para ler, para entrar em discussões, ela vai em algumas palestras, me traz segurança, porque está embasado em alguma coisa. Não é simplesmente 'não, eu não vou dar vacina porque eu não quero'. Ela estuda para saber por que ela não vai dar vacina. Ela estuda para falar por que o filho não vai comer tal alimento. Ela estuda... Então basta da forma que ela coloca para mim. (...) Eu confesso, eu não ia procurar isso daí para poder falar 'não, não vamos dar vacina', nem tentei. Mas ela já consegue, e é uma coisa que ela gosta, satisfaz ela. As listas de discussões que ela entra, e ela vai pegando as melhores coisas e vai me falando, coisas boas e coisas ruins (Diogo).

Assim, a maioria das mulheres estabeleceu uma relação de poder no domínio das decisões em saúde do filho, ancorada pela posse de informações e a maioria dos homens, por sua vez, não mostrou a mesma inquietação perante o assunto, se contentando com as informações trazidas pelas parceiras, sem demonstrar incômodo frente à desigualdade de gênero referente às escolhas em saúde do filho no ambiente doméstico.

O acesso à informação para esses pais trouxe sentimentos contrastantes, em que uns se sentiram privilegiados por fazerem parte de uma pequena parcela da população que possuem um conhecimento além do lugar comum sobre as vacinas, e outros que manifestaram que o acesso à informação trouxe-lhes angústia, pela responsabilidade de ter que manejar uma decisão nessa nova conjuntura de informações.

É tanta coisa, é tanta coisa que envolve, não é só dar [a vacina]. A pessoa não pensa, Carol, em tudo isso, em todas as implicações. E eu penso, que pena, não queria. Eu preferia não pensar. Preferia não saber, mas acho que quanto mais a gente 
sabe mais a gente sofre, né, com as coisas (Clara).

Então, como falo com meu marido, falei essa semana de novo depois desse programa da Futura [que abordou a temática de vacinação], talvez a gente fosse mais feliz se a gente fosse ignorante em relação a esse assunto (Ana).

A transformação que a posse dessas informações acarretou nesses casais foi tamanha que muitos relataram o interesse e reforçaram a importância de se ter mais informação sobre vacinação para todas as pessoas de forma mais abrangente, transparente e séria pelos profissionais da saúde, pelos Órgãos de saúde do Governo e pela mídia. Muitos inclusive concluíram seus depoimentos com falas neste sentido.

Mas acho que a vacina tem várias questões ali, que as pessoas não olham, e acham que estão super seguras em relação a sua decisão. E o não vacinar tem muitas questões que a gente olha, pesquisa, e toma a decisão super informada. Acho que os pais que vacinam deviam fazer o mesmo, todo mundo devia fazer (Clara).

Acaba se resumindo nisso, nas informações, a gente acaba tendo essa opção de optar em sim ou não, ou prorrogar, pelo fato da gente ter essas informações. Às vezes eu vejo que muitas pessoas não têm, tenho certeza que não têm, por isso que elas não têm essa opção de optar por sim ou não. Se de fato isso fosse mais divulgado, talvez essas pessoas poderiam optar ou não, tal, né (Manuela).

Eu acho que a falta de conhecimento e a falta de educação, saúde e falta de entender, até quais doenças são que as vacinas tratam... (...) Porque a gente via que a gente não sabia nada sobre o assunto, e penso que a maioria dos pais não sabe muito. Então, essa falta de conhecimento eu acho que é, talvez seja um dos fatores das pessoas ficarem um pouco mais, de ter mais hesitação entre algumas pessoas, de dar as vacinas ou não. Então, acho que é só isso (Hugo).

Paradoxalmente, os casais que vacinaram seus filhos demonstraram conforto e segurança com a posse de informações sobre vacina que tinham e não se sentiram destituídos desse conhecimento. De um modo geral, eles se consideraram bem 
informados sobre o assunto, percepção esta, porém, muito distante dos variados graus de conhecimento, após o acesso às informações sobre as vacinas, pelos casais que não vacinaram.

Acho que a vacinação é bem importante assim. Claro que se eu tivesse novas informações levaria em conta. Mas estou dizendo isso só porque estou falando da história que a gente teve com a Larissa [filha], a partir do que a gente tem de conhecimento. Se a gente começa a ter novos conhecimentos, claro que a gente pode mudar de ideia. Mas não é uma postura fechada e definitiva, ela é fechada e definitiva dentro do quadro atual de informações que a gente tem (Eduarda).

$\mathrm{Na}$ verdade eu e a Jaqueline, a minha esposa, a gente nesse ponto, acho que foi por pensamento. Em nenhum momento, a gente nem chegou a conversar 'olha, vamos dar a vacina, não vamos dar as vacinas. O que você acha importante?', não. Eu acho que a gente vive em um mundo moderno, onde as informações estão muito mais ao nosso dispor. Então, hoje só não é bem informado quem não quer. Então, se a gente estudou, se a gente tem uma posição que optamos, é porque você tem que ter uma mente aberta para as coisas. Então, essa é uma coisa lógica, não teve nem discussão sobre isso (Camilo).

As fontes de busca de informação sobre vacinação mais relatadas pelos casais que não vacinaram e alguns dos que selecionaram foram: os sites www.taps.org.br e http://imva.info (da International Medical Veritas Association); o livro "Vacinar, sim ou não? Na infância e na idade adulta. Orientação na perspectiva homeopática" (Ulrich Koch, Editora Paulus, 2004, $1^{\text {a }}$ edição); o site e os manuais do Ministério da Saúde ${ }^{16}$ e a discussão e textos oriundos de um grupo virtual chamado "vacinaveritas".

A literatura científica apresenta estudos que analisaram o conteúdo de websites com ideação anti-vacinação, enfatizando o caráter temerário pela grande presença de informações equivocadas e pelo apelo emocional aos pais leigos. Um deles analisou 22 sites em 2002 e encontrou as seguintes informações: 100\% disseram que vacina causa doença; 95\%, que vacina corrompe o sistema imunológico; 95\%, que os efeitos adversos são subnotificados ou mascarados; e 91\%, que a política de vacinação é

\footnotetext{
${ }^{16}$ O Ministério da Saúde, por meio do seu site e de manuais on line, oferece aos profissionais da saúde e à população em geral todas as informações sobre as vacinas, incluindo seus efeitos adversos e contraindicações (Brasil, 2008).
} 
motivada pelo lucro e não pela saúde (Wolfe et al., 2002). Outro estudo avaliou o conteúdo de oito sites anti-vacinação americanos e canadenses: 100\% abordaram segurança e eficácia das vacinas; $88 \%$ eram associados a pensamentos de medicina não convencional tais como: fitoterapia, homeopatia, quiropraxia, naturopatia e acupuntura; $88 \%$ enalteceram a liberdade dos pais com as decisões sobre o cuidado do filho, $63 \%$ consideraram as políticas de vacinação totalitaristas; $100 \%$ dos websites apresentaram alguma "teoria da conspiração", alegando que o Governo esconde informações sobre vacinação para a população e/ou que a vacina é feita para dar lucro à indústria farmacêutica; $88 \%$ tiveram alguma informação incorreta sobre o tema; e $88 \%$ fizeram apelo emocional com relato de pais com filhos autistas ou que morreram, cujo evento triste foi relacionado com a imunização do filho (Kata, 2010). A autora, porém, salienta uma limitação característica destes tipos de estudos, que é a transitoriedade da internet, em que site, endereços e conteúdos mudam constantemente.

A posse de informações, com o advento da internet, nunca foi tão acessível e abundante na história da humanidade. Para compreender o processo que envolve o acesso, a apropriação de informações e a reflexão em saúde, e as consequências nas interações humanas e nas relações com a saúde-doença, é importante situar o contexto mais amplo, que diz respeito às transformações da informação e da internet na sociedade contemporânea, para depois, fazer um paralelo com as repercussões dessas mudanças na área da saúde, e em especial, no campo da vacinação.

Alguns autores como Daniel Bell e Alain Touraine, ao analisarem a sociedade capitalista entre as décadas de 1960 a 1970, descreveram mudanças importantes que culminaram na proposta de chamá-la sociedade pós-moderna, sociedade pós-industrial ou "sociedade da informação" (Vieira, 2005). Entre as principais mudanças estão a diminuição do papel da indústria como base da economia, o aumento da especialização e de profissionais com conhecimento técnico específico, e uma tendência de desenvolvimento maior nas tecnologias da informação frente às de produção. Assim, o novo paradigma foi balizado, sobretudo, pelo papel central da informação, reformulando as relações de poder nos meios econômico, político e sociocultural, justificando a denominação de "sociedade da informação" (Vieira, 2005).

Apesar desse processo ter se intensificado após a década de 1960, foi a partir de 1990 que ele assume um novo formato de rearranjos nas relações e organizações sociais, 
as redes de comunicação digital. Para Castells (2005), essa sociedade emergente não está balizada apenas na informação - uma vez que para o autor a informação sempre foi um fator importante na emancipação e nas relações de poder das sociedades - mas o que "é novo é o facto de serem de base microeletrônica, através de redes tecnológicas que fornecem novas capacidades a uma velha forma de organização social: as redes" (Castells, 2005: 17), propondo o termo "sociedade em rede", que para ele é mais adequado que "sociedade da informação".

A internet e as redes digitais possibilitam o acesso a um nível exuberante de informações sem precedentes na história, diferente de outros meios de comunicação (como TV e rádio), pois há uma postura ativa nas buscas e interações, mesmo que virtualmente (Garbin et al., 2008). Elas propiciam um potencial processo de autonomia individual e grupal, mas paradoxalmente, o excesso de informação não vem necessariamente associado à apreensão do conhecimento e a uma postura reflexiva e crítica em meio a esse turbilhão (Demo, 2000).

Essa ambivalência também ocorre no tocante às informações em saúde. A internet e suas possibilidades passam a oferecer um enorme contingente de informações na área médica e de saúde, antes de exclusividade dos profissionais, em especial dos médicos. Essa nova conjuntura permite uma mudança no cuidado em saúde das pessoas, do ponto de vista de um ganho de autonomia - no âmbito do empowerment ${ }^{17}$ - e, por conseguinte, redefine a relação entre os profissionais de saúde e os sujeitos e grupos, em que a tradicional posição subserviente do paciente, a "confiança cega", é substituída por uma atitude ativa e de troca, a "confiança informada" (Espanha, 2013). Em outras palavras, se abandona "uma relação construída essencialmente a partir da interacção paciente-profissional de saúde, para uma relação construída a partir de múltiplas interacções, face a face e mediadas, com múltiplas tecnologias” (Espanha, 2013: 68).

\footnotetext{
${ }^{17} \mathrm{O}$ termo empowerment, que na língua portuguesa foi traduzido por empoderamento, surgiu de movimentos feministas e sociais, na luta pelos direitos civis, em países desenvolvidos a partir da segunda metade do século XX. Ele foi apropriado ao campo da saúde, se constituindo como uns dos principais cernes da estratégia de Promoção à Saúde, criada a partir dos anos 1970, com apoio da Organização Mundial da Saúde (OMS) e influência de resoluções de conferências internacionais, com destaque ao Relatório de Lalonde e a Carta de Ottawa, ambos canadense. Ciente da multidimensionalidade do termo, o conceito empowerment engloba o processo que envolve o aumento de autonomia e diminuição da dependência de instituições macrossociais, por meio do desenvolvimento de competências, confiança e autoestima individual e/ou coletiva. Emprestado ao campo da saúde e à estratégica da Promoção de Saúde, ele propõe que os indivíduos ou grupos aumentem a capacidade de controlar os determinantes de saúde e assim, alcançarem uma melhor saúde (Carvalho, 2004).
} 
Essa transformação, porém, não alcança todos os sujeitos da mesma forma, com a coexistência de diversos modos de relação, mesmo diante de um mesmo cenário atual de excesso de informações em saúde, como foi exemplificado pela diferença de postura dos participantes dessa pesquisa, aceitação plena nos casais que vacinaram e questionadora nos que não vacinaram. Por outro lado, os achados desse estudo dialogam com pesquisas na literatura que encontraram mais mulheres do que homens na busca por informação, e também, mais jovens que mais velhas, pelo maior uso da internet (Garbin et al., 2008).

Ademais, as informações em saúde disponíveis na internet muitas vezes possuem jargões médicos de difícil compreensão, uma pluralidade de informações ou informação "incompleta, contraditória, incorreta ou até fraudulenta. Por esta razão, o cidadão comum muitas vezes tem dificuldade de distinguir, por exemplo, o certo do enganoso ou o inédito do tradicional" (Garbin et al., 2008: 580), além de poder causar angústia e incerteza. Em alguns relatos dos casais que não vacinaram os filhos deste estudo, apareceu a problematização acerca da credibilidade das informações acessadas, principalmente por ser um assunto que contém uma especificidade e conhecimento técnico-científico que eles não possuíam. Por outro lado, essa percepção não ocorreu com boa parte dos entrevistados.

E aí comecei a estudar, mas estudar. Eu não sei nada de saúde, eu sou engenheira, eu e meu marido somos engenheiros, então é 'zero' e eu confio nos médicos. Eu confio nos seis anos que vocês passam pelo menos na faculdade. Então, li aquele livrinho "Vacinar sim ou não", li uns artigos, mas assim, li mas não confio nas minhas leituras, nas minhas análises, porque não tenho... Põe mercúrio, não sei o que, eu não tenho competência para isso, para avaliar se esse mercúrio vai ser bom ou não (Ana).

Aí fomos ver... Bom, têm as vacinas, aí têm alguns livros falando do negócio, tem essas fontes na internet, que claro, muitas vezes são erradas, muitas vezes são exageradas, e tudo mais. A gente tem essa consciência. (...) Sinto falta da informação assim, segura. Porque você tem muita informação na internet, mas você não sabe qual a fonte, se é verdade, se é mentira (Vinícius). 
Às vezes as informações de internet elas são muito assim, ou muito contra ou muito a favor. E daí elas acabam, quem é contra vem toda a informação contra e, quem é a favor, te dá toda a informação a favor. E você fica, daí você acaba sendo influenciada. O importante é você olhar dentro de você mesmo. Ver os fatos, os fatos mesmo. Ir no Ministério da Saúde, ver lá, está tudo lá, eles... Naqueles sites eles não escondem nada. E aí você pode tomar uma decisão melhor assim. Foi isso que eu fiz (Clara).

Assim, o "paciente informado", que possibilita uma maior autonomia em saúde, pode estar à frente de uma avalanche de informações de qualidade e validade duvidosa e de uma armadilha, em que a percepção de ter mais informação em saúde faça-o se sentir expert no assunto, mesmo diante da possibilidade da superficialidade do conhecimento adquirido.

Amplificam os nossos conhecimentos, as nossas ideias e as nossas possibilidades de intervenção, mas também promovem, com frequência, percepções confusas, perspectivas errôneas e conhecimentos conflituais e dispersos, quando não, unicamente, superficiais. É na dualidade destas possibilidades que o tal "cidadão informado" se move e se transforma (Espanha, 2013:26).

O cidadão ou "paciente informado", pelo sinergismo da melhora do nível educacional com o acesso a informações de ordem técnico-científicas em saúde, fez emergir um paciente (nesse estudo, representado pelas mães) que busca informações sobre seus sintomas, doença, tratamento medicamento, não medicamento ou outros alternativos etc., surgindo o "paciente expert". O "paciente expert" representa mais que o "paciente informado", pois ele se sente entendido do assunto (Garbin et al., 2008). Isso apareceu na fala de um homem, Fernando, que não vacinou a filha.

Acho que pela força da argumentação nossa, porque ninguém conhece muito de vacina na verdade. Aí você lê um pouquinho e já fica meio que entendido. E você fala 'você sabe que as vacinas têm mercúrio, conservante e tal' aí o cara já fica meio assim, de ter alguma argumentação (Fernando).

No âmbito da vacinação, Vasconcellos-Silva e Castiel (2010) ressaltaram que o sentimento de inquietude ou angústia pode levar alguns pais a buscarem informações e opiniões sobre vacinação e compartilharem-nas. Estas mães, assim, encontram uma enormidade de informações presentes na internet e se sensibilizam especialmente nos 
relatos pessoais (inclusive de celebridades) com alguma experiência negativa acerca da vacina dos filhos ou dos efeitos adversos, sem dar o mesmo peso aos benefícios da vacinação.

O "cidadão consciente de si" se torna, solitariamente, seu próprio expert, lutando contra as proliferações imaginárias que lhe parecem mais ameaçadoras. No âmbito da saúde, os discursos das instituições clássicas perdem seu poder de influência na polifonia de mensagens, abrindo terrenos espaçosos e férteis às redes de expertise informal (VasconcellosSilva; Castiel, 2010: s/n).

Esse fenômeno no campo da vacinação, que inclui a pluralidade de informações, a imprecisão de sua qualidade, e o perfil das mães experts, revelou outra característica, o modo como alguns participantes processaram as informações prós e contra vacinação se revelou seletivo, conforme a capacidade de captação subjetiva e interesse desses sujeitos, cuja "percepção está condicionada ao 'ponto de vista do observador', o que nos faz, ademais, prisioneiros de nossas próprias descrições" (Demo, 2000: 39, grifo do autor). Essa seletividade foi muito observada nas justificativas dos pais que não vacinaram (que será apresentada no próximo capítulo), em que os possíveis malefícios da vacina, que são reais, porém, raros e leves na grande maioria das vezes, se sobressaíram imensamente frente às informações que postulam os benefícios da vacina. Ademais, não obstante aos recentes esclarecimentos sobre a falta de evidência entre a associação da vacina sarampo, caxumba e rubéola ou do timerosal com o autismo veiculados em livros, na internet ou pela mídia (Offit, 2008; Godlee et al., 2011), estas questões ainda estão muito presentes e respondem com grande comoção nas falas de alguns pais, mesmo em se tratando de pais de alta escolaridade e acesso livre às informações conflitantes ou esclarecedoras.

Vivemos num tempo em que as informações em saúde veiculadas na internet são uma realidade em ascensão. Mais temerário que a existência de websites e outras fontes com informações e conteúdo de validade questionável são as atuais posturas, tanto dos pais leigos, quanto dos profissionais da saúde, gestores ou empresas farmacêuticas, de encararem a vacinação de forma polarizada, em correntes negativas ou positivas, como já salientava Moulin (2003). A melhor maneira de lidar com estas tensões é tratar a vacinação como um fenômeno complexo, como ela realmente é. 
Para concluir, a tomada de decisão em não vacinar os filhos, nesse grupo estudado, se contextualizou na crítica à prática obstétrica dominante no país e foi propulsionado pelas informações anti-vacinação advindas, sobretudo da internet e redes sociais, culminando na ruptura da credibilidade da vacinação infantil, uma medida de saúde até então respeitada por eles. 


\section{O CUIDADO INFANTIL E A (NÃO) VACINAÇÃO}

Este capítulo irá explorar como esses pais e mães significaram a vacinação, incluindo as concepções sobre as vacinas, as justificativas de não vacinar os filhos e os valores conformados às vacinas.

Para tanto, a interface entre cuidado e vacinação será analisada pela perspectiva do cuidado em saúde explorado por Ayres (2003, 2004), porém, se apropriando de um conceito mais amplo de cuidado, que extrapola a questão da saúde, ao referir-se à dimensão relacional e dialógica do encontro com o outro, em que o cuidado infantil será compreendido no contexto que envolve a dimensão de parentalidade desses casais de camadas médias escolarizadas de São Paulo.

Os casais que vacinaram conceberam a vacina como uma medida preventiva importante, associada aos valores de proteção e segurança à saúde do filho. A vacina foi vista como expressão do cuidado parental e responsabilidade dos pais. A expressão do sentimento de dever cumprido foi mais evidente nos relatos dos homens vacinadores.

[A vacinação] faz parte do 'take care', do cuidado ao filho, desde roupinha, quarto, enfim, plano de saúde e vacina. Pelo menos na minha cabeça tudo funciona como algo, tudo bem, tem a área da saúde, a área de lazer, os brinquedinhos tal, mas é um cuidar (Guilherme).

Eu vou falar uma coisa, eu já tinha antes claro para mim a importância de vacinar. Mas tendo minha filha, eu achei que isso me tocou muito mais. O medo de algumas doenças. Então de saber que se tem algum instrumento que a gente pode estar usando. Que nem meu marido falou 'a gente tem como principal recurso a questão da vacinação’ (...) Para nós, se tem que dar é dado no dia e ponto. É prioridade da gente essa questão da vacinação, da carteirinha em dia (Jaqueline).

Me sinto cumprindo o dever, assim como o pai tem que proteger, porque o bebê é indefeso, depende de tudo dos pais e da mãe, o pai e a mãe tem a obrigação de dar o cuidado, a proteção, alimentação e também as vacinações, etc. Então eu vejo como obrigação dos pais fazer isso (Bruno). 
Diante das práticas de saúde atuais, além da vacinação ser importante para a maioria desses casais, a vacina não foi associada a um medicamento ou um procedimento invasivo por uma participante, Fernanda. Para ela, a vacinação infantil ocupou um lugar diferenciado que, ironicamente, mesmo fazendo parte de um dos recursos mais prestigiados da biomedicina e da saúde pública e coletiva, a vacina foi apreendida justamente como uma proteção a essa biomedicina intervencionista, técnica e medicamentosa.

Eu vejo a vacina como algo protetor, como algo positivo, acho que diferente de outras ferramentas da medicina, algumas das quais eu até questiono, por exemplo, o excesso de exame, exames invasivos, tem que fazer check-up, tem que fazer 1001 exames o tempo todo, você acaba procurando pelo em ovo, quem procura acha. Com a vacina eu não tenho essa mesma abordagem, eu não sinto a vacina como uma coisa excessiva, como um excesso da medicina super medicalizando a sociedade. Eu vejo como uma abordagem diferente, eu vejo como algo protetor mesmo (Fernanda).

Houve um encontro harmônico entre o que esses casais traziam de valor quanto à vacinação, as prescrições dos pediatras e as proposições do programa público de imunização. Foi ressaltada e enaltecida a característica da prevenção associada às vacinas.

Talvez como engenheiro, a prevenção é muito melhor do que o cuidado, então tem que atuar antes, isso é fundamental, e as condições para ter as doenças infantis permanecem, o saneamento básico é precário no país, então eu acho que a questão da vacinação continua muito importante (Bruno).

Acho que a prevenção é do próprio Governo. Se o Governo tem dificuldade de investir na saúde pública, que infelizmente é muito precária, acho que a prevenção é sempre o melhor caminho. Hoje nós vivemos no mundo da prevenção. (...) Você previne para que não aconteça. Eu acho que o caminho é esse. (...) O caminho da prevenção (Camilo).

Os pais que vacinaram seus filhos associaram a vacinação infantil com o sentido da proteção que, diante das intempéries da vida, essa medida se destaca como uma 
ferramenta, entre outras possíveis, que protege e/ou previne o filho da doença e da morte. A noção de risco para esses pais, quando citado, foi relacionada ao risco da doença que a vacina protege. Os possíveis riscos associados às vacinas, ou não apareceram na fala desses pais, ou foram encarados como já conhecidos pela biomedicina e considerados muito pequenos se comparado aos benefícios.

Bom, a maioria das vacinas são vacinas que se usam há bastante tempo, que foram aperfeiçoadas cada vez mais. Até onde a gente conhece, o risco que tem é de uma reação exacerbada da vacina. Então, você tem a doença que ela busca combater em um nível bem mais baixo do que teria se não tomasse a vacina. Quer dizer, então para a gente, a desvantagem é você, a criança tem que tomar picada, é desconfortável. Mas é um desconforto que vai proteger ela de coisas piores, mais para frente. (...) O que eu posso dizer é assim: 'Será que todas eram necessárias?' Eu fico me perguntando, 'será que todas essas vacinas eram necessárias? Extremamente necessárias?' Talvez não extremamente, mas me parece que a escolha é a escolha de que risco você quer correr, entende? (...) Até aonde a gente sabe, a probabilidade dela ter qualquer problema com qualquer uma das vacinas que a gente deu era tão irrisório, e a probabilidade dela pegar qualquer uma dessas doenças era tão maior, que do meu ponto de vista, na circunstância que a gente teve, para mim não cabe nenhum questionamento (Eduarda).

Em relação à vacina é o meu lado mais, assim, eu arrisco menos. (...) Eu não me dispus a arriscar, assim ele ter alguma coisa que poderia ser evitada, uma coisa irreversível. (...) Eu acho que eu não me perdoaria se acontecesse alguma coisas, se ele pegasse alguma meningite, para mim seria uma coisa difícil pensar que ele pegou porque eu não dei vacina. (...) Óbvio que a gente não tem controle de tudo, mas algumas coisas podem ser evitadas, eu não vou correr o risco dele ter, isso é uma coisa um tanto tranquilizante, a gente vai passar por tantos outros apuros que esses pelo menos já estão resolvidos. Deixa vir o que vier aí para frente, outros acidentes de percurso, mas esse já passou (Beatriz).

É melhor a vacina para reduzir o risco de ter uma doença que muitas vezes são fatais, irreversíveis etc., como a poliomielite, e 
outras, meningite. (...) Tem que vacinar sim. Tem doenças que são mais leves, mas tem as mais perigosas, como a paralisia infantil que está praticamente erradicada, mas catapora, sarampo, essas doenças mais corriqueiras e tem vacina... Tem que dar vacina. Como não vai dar? São muitas vacinas hoje, né? Mas enfim, tem que dar, diminui o risco de acontecer alguma coisa ruim pro bebê (Bruno).

Nos casais vacinadores que selecionaram as vacinas, predominou a concepção que vacinação é uma proteção importante, seja para a saúde do filho como para a saúde da população em geral, mas o cuidado parental estava associado à busca pela singularização, conforme as particularidades de cada criança e seu contexto familiar, diante de uma recomendação universal. Na fala desses casais, é responsabilidade dos pais - com apoio maior ou menor do médico - escolher o que é melhor para seu filho, frente a normatizações e hábitos muito difundidos na sociedade, e essa escolha foi balizada no modo de vida único e no que faz sentido à biografia dessa família (Velho, 1987, 1994).

Acho que as decisões, todas, da vacina, do parto [humanizado] elas foram tomadas muito em função de dar o melhor, de individualizar casos, não generalizar. A sociedade generaliza tudo isso. Só que eu acho que eu tenho condições de tomar decisões e individualizar. (...) Então, acho que nisso que me baseei para decidir essas coisas [dar algumas vacina] (Andreia).

E ouvi relatos de outras pessoas que não deram e não aconteceu nada. E as crianças iam à escola e não tinha acontecido nada. (...) Está todo mundo vivo, super saudável... E isso me ajudou então a tirar um pouco da ansiedade em relação a que o cuidado significaria dar as vacinas, e que não era bem isso. Me ajudou a desmontar isso. Ver que tinha outras pessoas fazendo outras opções, fazendo opções e não seguindo a regra. Mas fazendo opções e que eram opções mais interessantes (Sílvia).

Nesse grupo heterogêneo, surgiram questionamentos pontuais de certas vacinas, como as recém incluídas no calendário básico de vacinação, as que protegem contra doenças que eles consideraram leves, ou as que causaram algum efeito adverso no filho. Em parte desses casais, apareceu o medo de algumas vacinas, diferentemente dos casais que vacinaram, relativizando a importância generalizada dada à vacinação infantil. Também se relativizou o valor associado à proteção, já que este foi particularizado a 
uma parte das vacinas e não todas, ou na ótica de Francisco, pela percepção que essa proteção é de ordem teórica e não visível aos olhos dos pais.

Agora, o positivo da vacina é proteger a criança, o indivíduo da doença. Que é uma coisa neutra, não tem um efeito positivo. A imunidade não é um efeito positivo, você não vê, é uma coisa intangível, então é um, digamos, é um bônus que você não recebe. Sei lá, não sei explicar direito, não é palpável. O que é palpável são os efeitos negativos. Então não teve nada palpável, nem negativo nem positivo (Francisco).

Nesse grupo, se destacou um casal, Sílvia e Hugo, que além de terem problematizado a vacinação antes de serem pais (ela por ter um irmão autista e ele por ser americano filho de uma mãe ativista contra vacina), vivenciaram uma experiência negativa em relação à vacinação do filho, suspendendo assim a continuidade do calendário vacinal. Diante do evento real vivenciado, a concepção de proteção associada à imunização foi questionada e desconstruída, o sentimento protetor ao filho se transformou e passou a ser atrelado à escolha de não vacinar mais.

Mas aí deu e Antônio [filho] chorou e fomos embora já. Eu acho que até menos, com menos vontade de continuar depois daquilo, por causa do ambiente, do jeito que foi feito. (...) E foi isso. A gente não voltou mais. Ele ainda tem vacinas no calendário, mas gente não tem voltado e já passou a agenda que eles deram para a gente. Eu ainda não me considero 'anti', mas também não vejo o porquê de continuar estendendo um pouco mais, e eu acho que o risco não justifica o sacrifício e o custo para ele, principalmente (Hugo).

Hoje eu não vacinaria o Antônio. O tipo de reação que ele teve, para o risco que teria em não vacinar eu não vacinaria. (...) Eu gostaria de ter me sentido segura como estou hoje para poder ter protegido meu filho dessas experiências ruins que ele teve. Que arranharam a confiança que ele tinha na gente, de ver como ele se sentiu traído na hora de tomar uma agulhada. O tipo de reação que ele teve, eu gostaria de ter protegido ele disso. Então, hoje me sinto muito segura para dizer que não vai tomar mais nenhuma, não deixo e meu próximo filho também não vai tomar nenhuma. E eu vou conseguir tomar essa decisão de uma forma mais segura, sabendo que assim eu vou estar protegendo meu filho mais do que dando as vacinas (Sílvia). 
Os casais que não vacinaram fizeram essa escolha visando "o melhor para os filhos". Nos seus depoimentos, a concepção de cuidado parental está também associada à proteção do filho, porém, de forma inversa aos casais vacinadores, proteger é não submeter os filhos à vacinação infantil.

Eu não estou fazendo isso porque eu não tenho um motivo, eu quero preservar, do mesmo jeito que os pais que vacinam também querem preservar a saúde dos seus filhos. É movido pelo amor que todo mundo toma a decisão que toma. E eu acho que devia encontrar um meio assim (Virgínia).

Então eu como pai, a gente quer proteger. 'Ah, a vacina protege?' Eu vou falar que não, porque já a Virgínia me mostrou por A + B que a vacina não protege. 'Ah, mas o Zé Gotinha?' Está erradicada do Brasil há anos, mais de 20 anos, que não tem nenhum caso. (...) Mas no meu caso eu evito vacinas. Se eu puder falar para uma pessoa em quem eu confio 'oh, vai estudar, vai ver que o negócio não é legal, você pode até matar o teu filho', mas muita gente não acredita, né (Diogo).

As pessoas vacinam e acham que estão livres de tudo, que elas estão super mega protegidas, e que não é bem assim. Na verdade as pessoas que não se vacinam acabam tomando muito mais cuidado, lavando mais a mão, outro tipo de precaução, e que as vacinas não são $100 \%$ eficazes, nenhuma é (Elaine).

Acho que não tem necessidade de vacinar. Ela está mais protegida assim (Amanda).

Em contraponto aos pais que vacinaram, que enalteceram o aspecto preventivo como um ponto importante na saúde do filho, um dos participantes entrevistados, Jonas, critica a política do Governo de dar preferência a essa medida preventiva.

Pô, 'mas e o Zé Gotinha?' O Zé Gotinha não é bom! O que tem que construir é saneamento básico, o Zé Gotinha é prevenção. A prevenção tem uma hora que não dá mais, você não pode ficar usando só prevenção, você tem que consertar. Prevenção é prevenção, conserto é conserto. É diferente, a palavra tem um significado diferente, tem uma prática diferente (Jonas). 
Entre esses casais que não vacinaram, o processo vivido que engloba a reflexão e o questionamento da vacinação, a decisão e a implementação de não vacinar os filhos conformou ressignificados importantes em termos de cuidado parental e no valor de proteção atribuído à vacina. Houve uma desconstrução e inversão da concepção de proteção associada à vacina e numa problematização em relação ao risco, em que a vacina passa a assumir significados de risco e ameaça à saúde do filho.

Para eles, seus filhos estão protegidos pelo amor, alimentação, aleitamento materno, condições socioculturais, entre outros cuidados, contextualizados em um modo de vida mais natural, sem excessivas intervenções científico-tecnológicas. Nesse cenário, a vacinação passa a assumir um significado de ameaça, um risco à saúde do filho e assim o sentimento de proteção está atrelado ao de não dar a vacina ao filho. Para eles, o risco de contrair as doenças preveníveis por vacina é muito baixo ou inexistente, o que não justificaria a vacinação, pois o único "ganho" seria o ônus dos efeitos adversos e outros aspectos negativos associados a ela. A concepção de cuidado desses casais, em que a escolha pela não vacinação é um melhor cuidar, se contrapõe à concebida pela biomedicina (CFM, 2011) e pelas normas legais preconizadas pela saúde pública, que enxerga a não-vacinação como ausência de cuidado ou negligência (Brasil, 1975; Brasil, 1990) ${ }^{18}$.

Hoje em dia, tendo a situação concreta, real, de decidir a vacinação de um ser, que depende de mim, eu enxergo a questão completamente diferente. Como vou tomar todas as vacinas que existirem, se todas apresentam risco, que é evidente que apresentam risco. Porque tem aquela frase, não sei se era do Paracelsus? Aquela frase 'não existe remédio, não existe veneno, tudo depende da dose'. Para vacina isso é verdade pura, né. Então, como eu vou tomar, correndo esse risco da droga, se eu não tiver nenhum risco de pegar a doença? Quer dizer, vou estar correndo um risco à toa, na verdade (Vinícius).

Se daqui a uns 20 anos ela [filha] decidir que ela quer ir para África, e ela acha 'vou me proteger', eu nem sei se proteger é a palavra certa, mas 'eu quero me vacinar', então, minha filha, você vai lá, lê e você resolve (Clara).

\footnotetext{
${ }^{18}$ Sobre isso ver capítulo 1.
} 
Um dado inusitado encontrado nesse estudo foi que, apesar das grandes diferenças nas concepções sobre vacina e o seu lugar na dinâmica do cuidado à criança, sobressai em todos uma perspectiva que aproxima de modo contundente as diferentes tomadas de decisões acerca de vacinar ou não a uma mesma ordem simbólica que norteia as representações dos pais sobre o que é o cuidado parental: proteção, responsabilidade e dever. Prevaleceu a concepção moral de cuidado ao filho, em que cuidar é proteger a criança, um ser dependente, porém, o que diferiu nos casais foi que, para os que vacinaram, proteger é vacinar os filhos; para os que selecionaram, proteger é singularizar caso a caso; e, por fim, para os casais que não vacinaram, proteger é evitar os riscos oriundos da vacinação.

Nesta perspectiva, o segmento social investigado apresenta especificidades quanto ao padrão sociocultural que podem ajudar a discutir esses achados. Sociologicamente, Velho $(1987,1994)$ aponta algumas peculiaridades das camadas médias urbanas nas sociedades complexas contemporâneas, em que o universo simbólico é marcado pela valorização do indivíduo, protagonista de suas escolhas e projetos, frente a um campo de possibilidades. Nesse sentido, tomam corpo valores de igualdade e liberdade, em que o sentido de vida do indivíduo estará desenhado conforme sua singularidade e biografia.

Sugere-se que tais características marcantes desse segmento social corroboram para o reconhecimento por parte de pais e mães que as decisões e escolhas sobre os cuidados ao filho, incluindo a (não) vacinação devem ser protagonizadas no âmbito do privado, e não alvo da intervenção externa, seja ela biomédica ou governamental. Assim, nos depoimentos dos casais que não vacinaram ou selecionaram as vacinas, se criticou a apropriação biomédica - medicalização da infância - e a intervenção do Estado no cuidado infantil (Orlandi, 1985; Costa, 1999), infringindo o poder de autonomia dos pais nas decisões sobre a saúde dos filhos. Em contraponto, não se encontra essa percepção ou preocupação por parte dos casais que vacinaram. Todos os participantes, seguindo a lógica de Velho $(1987,1994)$, se sentiram atores que fazem escolhas. Em outras palavras, nem a aceitação plena da vacinação, nem o questionamento influenciado por grupos da maternidade ativa ou parto humanizado, para os participantes, anulou o protagonismo do processo de escolha. 
A interface da parentalidade e do cuidado infantil com a biomedicina revela, na perspectiva da história factual, curiosas confluências e tensões. No final do século XIX e início do XX, se construiu uma aliança entre as mulheres das camadas altas e médias urbanas com os médicos higienistas, puericultores e pediatras, resultando na valorização da maternidade como função social, pública e política (Freire, 2009; Nunes, 2011; Novaes, 2009). Essa nova maternidade que se enaltecia, expressão de modernidade, se fundamentou na condição biológica e essencial da mulher, onde seu principal papel social era o de ser mãe, e foi validada pela lógica e discurso científicos, tanto que Freire (2009) utilizou a terminologia "maternidade científica"19. Esta, assim, assumiu um contraditório lugar de ser algo inato da mulher e, ao mesmo tempo, algo a ser aprendido e incorporado pelos ensinamentos médicos.

Essa afinidade entre médicos e mulheres das camadas altas e médias urbanas se estabeleceu pela convergência de interesses específicos de cada um que, por sua vez, trouxe vantagens para ambos. De um lado, os médicos - impregnados pelas correntes nacionalistas que difundiam que o futuro da pátria dependia da saúde das nossas crianças - assumiram a meta de diminuir a elevada mortalidade infantil mas, para tanto, trouxeram para si a responsabilidade de preparar as mulheres em como ser mães, propondo uma maternagem medicamente orientada com normas e regras sob os princípios da higiene (Novaes, 2009; Freire, 2009; Nunes, 2011). Esse percurso foi sustentado por dois pilares principais, o esforço de se legitimar o conhecimento de base científica, em detrimento de outras artes de curar, e a busca de introjetar na sociedade e na família a autoridade médica nas questões de criação e saúde da criança (Freire, 2009). De outro lado, as mulheres de maior nível socioeconômico, imersas na representação da época que associava a maternidade científica com o ideário da mulher moderna, perceberam que a parceria com os médicos poderia levá-las a um ganho secundário, à valorização social. Essas mulheres, agora detentoras de saberes e práticas reconhecidos e apreciados socialmente, pela ciência - até então quase exclusivo do universo masculino - redefiniram as relações de gênero no âmbito doméstico e melhorou sua posição social para além dele. As que alcançavam o patamar da maternidade científica abriam-se portas para ocupações profissionais fora de casa, como ações filantrópicas ou como visitadoras sanitárias, por exemplo. “Tal aliança, ainda que

\footnotetext{
${ }^{19}$ Terminologia criada pela historiadora americana Rima Apple (Freire, 2009).
} 
simbólica, ao aproximá-los sob a valorizada atmosfera da ciência, contribuiria para propiciar aos puericultores sua afirmação profissional, e às mulheres, o reconhecimento de sua função social como mães" (Freire, 2009: 201).

Nesse cenário, se fortaleceu a medicalização da infância, em que os médicos começaram a definir e tomar decisões acerca de processos fisiológicos no campo infantil, de forma sem precedentes na história social da infância. Característica, cor e dimensões do berço, noções de limpeza pessoal e ambiental, temperatura ideal do quarto do bebê, fervura da água para beber, como processar e limpar os alimentos, tipos e quantidade de alimentos por faixa etária, necessidade de banho de sol, higiene dentária, estímulo à atividade física, enxoval do bebê, número ideal de trocas de fraldas, posição, temperatura e lugar para um sono adequado, necessidade de repouso, manejo da criança doente, sugestão de ter um kit com os medicamentos básicos para qualquer emergência na criança, recomendação para levar em um pediatra de forma regular, necessidade de se acompanhar o peso, altura e desenvolvimento da criança, brincadeiras adequadas, segurança, até preocupações com a educação e formação intelectual, emocional, moral e de caráter na criança se tornaram objetos de saúde regidos pela autoridade médica (Freire, 2009; Nunes, 2011).

A confluência do discurso médico-higienista e puericultor e do maternalista feminino, estava em harmonia e conveniência com os ideais de modernidade das mulheres de camadas altas e médias urbanas. Porém, a medicalização da criança também alcançou as camadas populares, já que aquelas passariam a ser um modelo a ser copiado por estas (Freire, 2009). Assim, o Estado intervém nas famílias pobres, sob forma de proteção, tutela e assistência, e difunde o exemplo de sucesso das premissas higiênicas e puericultoras por meio das famílias ricas (Freire, 2009; Nunes, 2011).

Nas normatizações dos modos de cuidar da criança e dos procedimentos visando a prevenção de saúde e a queda da mortalidade infantil, se fortalece e expande a recomendação médica acerca de uma nova e "moderna" ferramenta preventiva, a vacinação infantil. Na primeira metade do século XX, sobretudo a partir de 1920, com as vacinas recém descobertas contra tuberculose, coqueluche, tétano e difteria, além da contra varíola e antirrábica desenvolvidas no século anterior, a vacinação ganha reconhecimento e se difunde nos discursos e práticas médico-higienista e puericultor, e 
passa a ser recomendada como rotina estendida à população em diversos países, incluindo o Brasil (Plotkin et al., 2008).

Paradoxalmente, nos anos 2000, é nesse segmento social que emergem grupos que entendem que o cuidado parental remete ao domínio do privado, locus onde a autonomia e a liberdade devem ter preponderância. Algumas mulheres das camadas médias urbanas resgatam a determinação biológica das funções femininas - a semelhança da maternidade científica descrita anteriormente - mas também buscam outras formas de interlocução em saúde, além da mediação dos biomédicos, e propõem romper com as padronizações fechadas, entendendo que as decisões parentais no cuidado infantil devem ser constituídas conforme o universo cultural e de valores familiares ou o modo de ser e viver no mundo (Ayres, 2003). Nesta nova configuração histórica, alguns grupos do segmento das camadas médias e intelectualizadas se permitem romper com premissas biomédicas até então consagradas e defendidas, como é o caso da vacinação infantil e do calendário preconizado pelas normas vigentes da saúde pública brasileira.

Não menosprezando as consequências de uma queda da cobertura vacinal à coletividade e ciente da complexidade do tema, este estudo propôs transferir a atenção não no julgamento de ausência ou presença de cuidado, e na apreciação de ausência ou não de negligência dos pais que não vacinaram, como tradicionalmente ocorre nas discussões da biomedicina e saúde pública, que se fundamentam no princípio da rejeição à vacina (Moulin, 2003) e na premissa que a não-vacinação é maus tratos à criança tutelada pelo Estado (Brasil, 1990). Norteada pela contribuição da socioantropologia que busca compreender o fenômeno pela aceitabilidade à vacinação (Moulin, 2003), assumindo a importância da voz dos sujeitos para a compreensão da ação social, esse estudo mostrou que na ótica e praxis dos pais que não vacinaram ou selecionaram, o exercício parental no cuidado ao filho, simbólica e moralmente, esteve sempre presente, tanto quanto nos casais que vacinaram seus filhos, não podendo ser configurado, então, negligência parental. O que se diferenciou, no entanto, foi como esse cuidado foi concebido e processado pelos participantes, em que predominou um cuidado parental mais refletido e trabalhado, dentro da perspectiva do empowerment, e mais questionador diante das premissas do cuidado infantil oriundas da biomedicina nos casais que não vacinaram, em comparação com os que vacinaram. A seguir, dando 
continuidade à compreensão da aceitabilidade à vacinação, serão apresentadas as justificativas da não vacinação e a discussão acerca dos valores ressignificados entre risco e proteção atrelados à vacina.

\subsection{Justificativas pela não vacinação}

As justificativas que balizaram a decisão pela não vacinação apresentadas pelos casais que não vacinaram ou que selecionaram as vacinas serão descritas a seguir:

\section{A doença está eliminada ou controlada no Brasil}

Eles argumentaram que não há necessidade de vacinar os filhos, pois a doença em questão já está controlada. Nestes relatos percebe-se o uso erradicado como sinônimo de eliminado.

Muita gente fala 'poliomielite', a poliomielite está erradicada no Brasil há muito tempo, então não tem porque botar o vírus na criança por causa disso (Diogo).

Pólio, não tem pólio. Eu não vou dar uma vacina para a minha filha que pode dar pólio nela, não vou. Qual a chance dela pegar pólio hoje em dia? Não vai pegar (Clara).

\section{A doença que a vacina protege é leve}

Alguns pais consideraram certas doenças leves ou sem gravidade, e sentiram-se confortáveis e com segurança de tratar a enfermidade sem o auxílio de uma intervenção médica. Assim a vacina passa a ser desnecessária. Referiram, sobretudo, à vacina contra rotavírus e gripe.

Tinha algumas que eu achava que não tinha porquê. Rotavírus, não, acho que o corpo dele pode cuidar disso de outra forma (Sílvia).

Agora, rotavírus não acho que é um bicho de 7 cabeças. Uma 
gripe suína... Porque se é para dar, uma criança bem alimentada, sabe, que se tiver alguma coisa, vai ter assistência (Isabel).

\section{Medo dos efeitos adversos graves}

Alguns participantes apontaram a reatogenicidade das vacinas e o medo da segurança das vacinas, principalmente o medo dos efeitos adversos graves, como razão de não vacinar. Entre os mais temidos estão a poliomielite paralítica associada à vacina Sabin e o autismo relacionado à vacina MMR.

Só falar que de um milhão de vacinações só um caso que dá problema... Mas se esse um caso for o seu filho? Você não está nem preocupado com a estatística, toda a vacinação deu errada, né (Fernando).

E eu acho que se você pode pegar sarampo, sarampo é até uma doença grave. Mas a vacina de sarampo pode dar o sarampo, pode ter outros efeitos colaterais graves ou até mais graves, morte súbita. (...) Ai eu fiquei 'não vou dar'. Aí eu fui ver se tem sarampo no momento e não tem. Então tá, vamos deixar, mas se vier a ter uma epidemia de sarampo a gente vai estudar qual é a melhor forma de lidar com isso (Clara).

Existe uma polêmica por detrás de autismo, mas pelo que eu tenho lido, não tem outra explicação. E tem uma pesquisa feita que comprova que a MMR, eu acho, não causa autismo, mas a pesquisa não é bem feita, é para uma vacina só, então acho que ela não é conclusiva e acho que existe muito interesse comercial tanto por conta do Governo como dos laboratórios para que isso não aconteça, não tenha pesquisas efetivas (Virgínia).

A que eu tinha muito medo, que tinha lido muita coisa era a de sarampo, a MMR. Era sarampo e mais não sei o que. Que estava dando muito problema, estava sendo ligada a autismo e tal, então essa eu tinha certeza que não queria dar e não ia dar em hipótese nenhuma (Andreia). 


\title{
Medo dos efeitos a médio e longo prazos
}

Certos entrevistados argumentaram o receio que as vacinas podem fazer no organismo, alguns a médio e longo prazos. Referiram-se ao aumento dos casos de doenças alérgicas e autoimunes e à possível correlação com o aumento do número de doses de vacina no indivíduo, em comparação quando eles foram vacinados na infância.

\begin{abstract}
Além disso, depois que elas foram divulgadas em massa, houve casos de reações adversas, além do aumento de caso de doenças autoimunes, por exemplo. (...) O que eu tenho visto é que as vacinas além de causar doença elas prejudicam o sistema imunológico das crianças, então com isso eles são mais susceptíveis às doenças que a vacina teoricamente deveria prevenir, então o principal motivo é esse (Virgínia).
\end{abstract}

\section{Crítica à composição da vacina e seus riscos à saúde}

Alguns entrevistados questionaram os conservantes, adjuvantes e outras substâncias que fazem parte da composição da vacina, sobretudo dos possíveis metais como alumínio e mercúrio (timerosal) e suas consequentes repercussões negativas à saúde.

Agora é claro que se você põe mercúrio em uma pessoa, no corpo de uma pessoa, vai ativar tudo que você já tem de mal dentro de você, que você já vem com os seus antecedentes. Se o mercúrio já faz mal para os nossos rios, imagina quanto que vai fazer para a gente (Jonas).

E a questão da vacina, de tudo que ela tem, de como é feita, dos químicos que eles põem, os metais. $\mathrm{E}$ a quantidade que é dada em uma criança antes do $1^{\circ}$ ano. Mas como que é isso a longo prazo? Não tem efeito cumulativo? O mercúrio não é simplesmente, a gente não expele mercúrio, ele não sai, ele fica ali, ele vai acumulando. Alumínio também (Clara).

Outros fizeram crítica às vacinas polivalentes (aquelas em que têm diversas vacinas agrupadas em uma única aplicação). Este ponto se divergiu da posição dos casais que vacinaram, os quais veem justamente nisso uma vantagem, a redução das picadas ao filho e um fator determinante de irem em clínicas privadas.

[Falando das vacinas polivalentes] É coerente também, se você 
for dar vacinas, não dar tudo de uma vez, porque como é que você vai por tipo cachorro, coitado, tem aquelas vacinas que são 10 vacinas juntas, acho judiação (Amanda).

[Em contraponto, relato de Alessandro que vacinou a filha] A gente levou alguma vez no posto, não lembro o porquê. A vacina de gripe a gente deu na campanha. Mas as vacinas em geral a gente leva lá na clínica e acho que o único critério é esse, o menor número de picadas que puder dar na pequena assim (Alessandro).

\section{Crítica ao mecanismo de ação da vacina}

Alguns casais criticaram o mecanismo de ação da vacina. Quem usou esse argumento recebeu muita influência da medicina não convencional (homeopatia, antroposófia e medicina chinesa), sendo contrário à administração de uma substância química num corpo saudável, pois pode gerar uma desarmonia no indivíduo e levar à doença ou a uma fragilidade no organismo.

Você fortalece o organismo para que? Não para evitar doenças, mas se você tiver alguma doença, seu organismo vai estar apto para combater, para resistir e para se curar. (...) Tanto pela chinesa quanto pela homeopatia, é meio incoerente você introduzir uma doença em um organismo saudável para fazer ela combater essa mesma doença, sendo que ela pode acabar desenvolvendo a doença daquela vacina. Então falei 'não é coerente', o coerente é você fortalecer o organismo, e se pegar uma doença, pegou. Se pegar você consegue sarar. (...) Mas se eu posso preservar o organismo, se eu posso criar um organismo mais forte, por que eu vou debilitar o organismo de propósito? Eu não acho coerente isso (Amanda).

\section{A imunidade natural é melhor que a gerada pela vacina}

Alguns usaram a justificativa que a imunidade gerada pela doença é melhor e mais duradoura que a gerada pela vacina. Logo, para eles, é melhor pegar a doença e se curar do que dar a vacina. Isso divergiu de alguns relatos de pais que vacinaram os filhos, que manifestaram o desejo de dar todas as vacinas possíveis para evitar que seus 
filhos pegassem qualquer doença.

$\mathrm{Eu}$ acho que se a Mariana [filha] pegar ali uma rubéola ela vai adquirir ali uma imunidade tão eficiente, mais eficiente do que uma vacina, porque é uma vez só, você pegou, resolveu e pronto. Uma caxumba também (Clara).

Agora, se alguém tiver catapora, acho que levo ela para brincar e pegar catapora logo de uma vez. Faço a festa da catapora, a festa da caxumba, eu faço. E pior que tem um grupo de mulheres que se um filho está com tal doença, a mulherada vai lá levar para a criança pegar logo, 'pega logo, a gente trata logo e já se livra disso' (Amanda).

[No contrapelo, o relato de Jaqueline que vacinou a filha] A Lia [filha] e mais um menininho que tomaram a vacina não pegaram catapora [num surto na creche]. Os outros 12 pegaram catapora. (...) Então, realmente, ali para mim eu falei 'valeu', e eu vi um monte de mãe falar 'ah, mas é bom que pegue', sabe aquela 'é bom que pegue tudo agora', eu falei 'eu não quero que pegue, se puder não pegar é melhor’ (Jaqueline).

\section{Crítica à eficácia e eficiência da vacina}

Alguns pais justificaram que a vacina não protege $100 \%$ contra uma determinada doença, questionando sua eficácia e efetividade.

A primeira coisa foi que eu não encontrei em nenhum lugar evidência científica que comprove a efetividade das vacinas. (...) $\mathrm{Na}$ verdade o que te faz dar ou não? Tudo está baseado no seu medo de que seu filho vai morrer, no final da história é isso. Então, se meu filho não tomar a vacina ele pode pegar uma doença que seja letal. Se eu der a vacina, eu tenho $100 \%$ de chance que aquela vacina vai evitar que meu filho tenha essa doença? Não. E ainda tem muitos casos de crianças que contraem as doenças pelas quais elas são vacinadas (Virgínia).

\section{Crítica a como o calendário de vacinação é preconizado no Brasil}

Alguns participantes questionaram a maneira que o calendário vacinal é 
preconizado no Brasil, incluindo críticas à idade precoce de início da administração das vacinas (recomendação de iniciar o esquema ao nascimento, com duas vacinas, a BCG e Hepatite B), ao elevado número de vacinas oferecidas ao mesmo tempo, ao grande número de doses no primeiro ano de vida e às datas preconizadas. Levam em consideração esquemas vacinais de outros países e o fato do sistema imunológico da criança estar em desenvolvimento até seis meses de idade.

Esse processo do Leonardo [filho], o Fábio [marido] bancou que ele não fosse vacinado na hora, enfim pelos mesmos motivos, a gente não achava que fazia sentido, a criança está muito frágil, a medicação alta, que podia ter várias reações, e as pesquisas mostravam isso mesmo, as reações que davam eram nos muito pequenininhos, então ele não seria vacinado até os seis meses (Elaine).

E depois de uns estudos que eu vi também, dessa determinação do Japão e da Alemanha de não vacinar crianças até os dois anos, achei que fazia todo o sentido essa informação. Com todos os problemas que qualquer criança teve com vacina, sempre foi muito cedo, porque muitas vacinas foram dadas ao mesmo tempo e muito cedo. Então, o meu inimigo não é a vacina e sim a maneira como ela é administrada, a quantidade que ela é feita e tal. Então, a minha intenção é pensar nisso com cuidado e decidir quando dar cada uma delas e quais dar (Andreia).

Eu já sabia que o leite materno tem muitas coisas, que a criança vai se desenvolvendo, a criança não nasce pronta. Que ela vai desenvolvendo o seu sistema imunológico também. E eu sei, sabia também que a criança tinha reações às vacinas, não só criança, todo mundo, se não tiver reação não adiantou tomar a vacina. E daí a gente concluiu, de comum acordo, que não precisava dar um coquetel de vacina para o Max. Alguma coisa que podia dar, podia até dar doenças nele e que podia dar, sei lá, ter um efeito pesado, mais pesado que o necessário, que a gente podia dar as vacinas aos poucos, sem dano para ele, sem dano para a saúde dele. Então, foi tranquilo (Francisco).

O que eu li, assim, que também me ajudou 'o bebê não tem o sistema imunológico formado, está em formação’. É uma 
questão que até hoje eu tenho, por que a gente vacina um bebê se ele não está formado o sistema? Se está bem no comecinho de formação? Então assim, todas essas questões a gente foi 'vamos deixando, vamos deixando', não é que a gente decidiu não vacinar, a gente está adiando (Ana).

Diante de uma normatização generalizada do calendário básico de vacinas no Brasil, alguns participantes sugeriram a singularização, em que a escolha de qual vacina e quando tomar deveria ser pautada no estilo e nas condições de vida e outras situações como contato com alguém doente, viagem/mudança para algum local onde circule determinado agente, etc.

Se eu tivesse algum tuberculoso na família, que eu convivesse com essa pessoa, que a Laís [filha] tivesse contato, eu pensaria 'olha, acho que a vacina da tuberculose é uma coisa para a gente pensar, fulano está com tuberculose, a gente tem contato, melhor prevenir', aí nesse caso talvez. 'Olha, realmente, o contato tem que ser prolongado, tudo, mas é um negócio a se pensar’, então, para mim hoje está fechado, por mim não vacino ela (Amanda).

Em relação ao caso específico da vacina contra hepatite B, muitos destes pais, ao se informar sobre o modo de transmissão desse vírus, que é por via parenteral, sexual ou de transmissão vertical, da mãe infectada para o filho, decidem particularizar a decisão conforme sua situação. No exame de pré-natal, ao confirmarem que a mulher não tem sorologia positiva para hepatite $\mathrm{B}$, decidem não dar a vacina ao filho no nascimento como recomendado pelo PNI - e resolvem postergá-la até a pré-adolescência, antes do início da vida sexual do filho:

Hepatite não vou dar, porque é por sangue. É verdade que ele pode precisar de uma transfusão, mas nem isso vai me fazer vacinar, pesando os prós e os contras. (...) Quando forem mais velhos, com 12 anos acho que eu vou dar hepatite nos dois [filhos], é isso (Andreia).

\section{O modo de vida como protetor de doenças e preditor de saúde}

Certos entrevistados argumentaram que determinantes sociais do adoecimento como as condições socioeconômicas e estilo de vida eram protetores de doenças e preditores de saúde. Eles partiram do pressuposto que muitas das doenças em geral 
(incluindo as imunopreveníveis) são ocasionadas pelas más condições de saneamento básico e/ou condições alimentares desfavoráveis. No depoimento desses participantes pesquisados, há uma sensação de imunidade a certas doenças, por considerar que a boa moradia, amamentação, alimentação adequada, além de outros aspectos como os de ordem afetivo-emocional, conferem-lhes proteção e qualidade de vida aos filhos e, neste sentido, a vacina passa a ser vista como dispensável.

Porque assim, a maior parte das doenças estão erradicadas. As que poderia ter ela acaba não tendo contato, que são, a maior parte delas depende de condições insalubres, exposição, coisa que ela não passa e não tem. Então a gente achou que era, ainda mais como bebezinho, era uma exposição desnecessária dela. (...) Não foi 'ah, não vamos vacinar, deixa, porque nós temos preguiça de ir no posto ou não queremos gastar dinheiro com vacina'. Então a gente optou conscientemente por não vaciná-la para não expor ela a certos tipos de contágios que na vidinha dela normal ela nunca teria exposição. Então a gente achou conveniente não ter essa exposição (Fernando).

O que eu tenho estudado é que se eu tomo determinadas atitudes de vida, não só não vacinar, mas ter uma boa nutrição, ter um estilo de vida saudável, atividades físicas, dormir bem, ser feliz... É todo um contexto, um estilo de vida diferente, isso promove uma boa saúde e aí eu consigo diante de uma doença que o organismo do meu filho responda adequadamente (Virgínia).

\section{As vacinas não foram as responsáveis pelo controle de algumas doenças}

Alguns pais questionaram o papel da vacina na eliminação de algumas doenças. Argumentaram que o controle da patologia ocorreu não pela vacina, mas pelo ciclo natural das doenças infectocontagiosas, que ao diminuir o número de pessoas susceptíveis, o patógeno deixou de circular e, por conseguinte, cai o número de casos da doença.

Eu falei 'não tem tanta prova de que a vacina é responsável pela erradicação da doença, não tem como você fazer um estudo e não tem como você provar ah foi a vacina'. O livro de 'Vacinar sim ou não' (...) ele fala que toda doença atinge um pico de 
indivíduos contaminados e depois vai, como se fosse seleção natural. Todos os indivíduos debilitados são contaminados e os que não são debilitados têm uma resistência à doença e aí o que acontece? Diminui o número de indivíduos contaminados, porque ou morre ou porque sara. Então, assim, eu falei 'é muito mais lógico isso do que você vacinar' (Amanda).

De acordo com o que eu li, já havia uma queda em relação ao número de casos de doentes, antes das vacinas terem começado a serem usadas (Virgínia).

\section{Crítica ao ganho financeiro e interesse comercial das indústrias farmacêuticas}

Alguns entrevistados fizeram uma crítica ao ganho financeiro e interesse comercial das indústrias farmacêuticas. Eles referiram que as escolhas sobre as vacinas e os calendários vacinais não são neutras ou embasadas unicamente no benefício à saúde, e acreditaram que haja interferência de outra ordem, cujo objetivo era dar lucro às indústrias farmacêuticas.

Porque hoje tem muito a questão comercial, acho que as vacinas devem ser um filão maravilhoso para as indústrias. Porque 100 milhões, da gripe, 100 milhões, se custar 1 real, o cara fatura 100 milhões. Deve custar 30 reais, então deve estar faturando bilhões. Então, a gente faz um baita de um filtro. (...) Eu estava falando do viés comercial também. (...) Tem clínicas, que a clínica é o pediatra e o centro de vacinação. E aí você sai com receitinha de vacina, quer dizer, e a vacina custa 700 reais, 1.500 reais. Tem até um pacotinho, se você levar todas as vacinas vai ser tanto. Então isso vai me assustando, me assusta (Ana).

$\mathrm{Eu}$ comecei a achar muito mais prova para as coisas que eu suspeitava. Para as razões mercadológicas para existir vacina, para se vacinar tanta gente sem necessidade (Andreia).

Só curiosidade sobre o processo de desenvolvimento e evolução das vacinas. Da distribuição das vacinas no Brasil. (...) Esse lance da vacina acelular, que não é distribuída para o povo. $\mathrm{E}$ por que não? Ele [pediatra] falou que são 40 anos de tecnologia, de diferença tecnológica na produção da vacina. Puxa, 40 anos, 
será que já não deu tempo de baratear esse processo? Disponibilizar para a população? Estranho, né. Há 40 anos isso existe na rede particular, tem gente ganhando muito dinheiro com isso, de uma elite que tem dinheiro para pagar, sem peso na consciência, uma nota preta. Uma vacina que é a melhor, sendo que o povo, que tem direito constitucional à saúde, gratuita, pública, não tem acesso à vacina melhor (Francisco).

$\mathrm{Eu}$ acredito que existe um fator econômico também em vacina, na medicina. Tem muito laboratório, tem muito assunto que eu realmente às vezes não acredito $100 \%$ que seja em busca de saúde pública, eu acho que têm alguns interesses por trás. (...) Eu tenho um pouco de dúvidas, às vezes, de quem está por trás de algumas vacinas. Eu acredito que existam muitas vezes interesses econômicos, por isso que a gente se aprofunda um pouco mais. Ainda mais eu vivendo no mundo de negócios, eu vejo que muitas vezes o que importa é o dinheiro, e não a saúde pública, que deveria ser (Nicolas).

As justificativas desses casais que não vacinaram ou que selecionaram as vacinas foram muito semelhantes às encontradas nos resultados de estudos conduzidos em países desenvolvidos: a doença que a vacina previne não é grave ou é de fácil tratamento (Bedford; Elliman, 2000; Mills et al., 2005; Benin et al., 2006); a doença não é frequente ou já foi eliminada (Bedford; Elliman, 2000); a vacina não é eficaz (Bedford; Elliman, 2000; Wolfe; Sharp, 2002; Mills et al., 2005); a vacina não é segura (Bedford; Elliman, 2000); não se sabe os efeitos a médio e longo prazo (Mills et al., 2005); medo das reações adversas (Mills et al., 2005; Benin et al., 2006); a vacina é dolorosa (Mills et al., 2005); o filho está protegido pela vacinação das outras crianças (Benin et al., 2006); a imunidade adquirida pela doença é melhor que a pela vacina (que gera uma imunidade temporária) (Wolfe; Sharp, 2002; Mills et al., 2005); acreditam mais na abordagem da medicina não convencional (como homeopatia e antroposofia) (Bedford; Elliman, 2000; Benin et al., 2006); buscam um estilo de vida saudável e outros métodos alternativos de proteção (Wolfe; Sharp, 2002; Mills et al., 2005); são contrários à forma autoritária das políticas públicas de vacinação (Wolfe; Sharp, 2002); e que as vacinas são oferecidas para dar lucro às grandes empresas farmacêuticas (Wolfe; Sharp, 2002; Mills et al., 2005; Benin et al., 2006). 
O peso das informações em saúde da internet e redes sociais na problematização da vacinação infantil, que permite a disseminação de dados, anseios, relatos sobre as vacinas em nível global, é um dos principais fatores que explicam as similaridades das justificativas aqui encontradas com as de países desenvolvidos, que apresentam relevantes diferenças sócio históricas e epidemiológicas nessa temática.

Ciente da complexidade do tema, este estudo propõe enxergar essas justificativas não pelo padrão biomédico, como na maioria dos estudos encontrados na literatura científica, que vão atrás dos motivos da rejeição à vacinação. Pretende sair da lógica normativa que preestabelece um lugar rígido e atemporal da vacinação na sociedade, abordando o fenômeno em termos de aceitabilidade (Moulin, 2003), pois permite agregar a dimensão socioantropológica e histórica à problemática em questão.

Diante dessa ótica, as justificativas relatadas pelos casais enunciam razões para além do medo do autismo associado com a vacina MMR desencadeada pelo trabalho fraudulento de Wakefield et al. (1998), como ocorreu no país locus do evento, a Inglaterra (Godlee et al., 2011). Os depoimentos dos casais participantes desse estudo mostraram sinais desse impacto, porém, ele foi expresso majoritariamente de forma indireta, pelo medo dos efeitos adversos e pela crítica à segurança das vacinas. Uma menor repercussão também foi evidenciada nos Estados Unidos da América (Colgrove, 2005). Para avançar na discussão desses dados empíricos, essas justificativas podem ser compreendidas, em parte, pela perspectiva da história factual da vacinação, pela caraterística das estratégicas populacionais em saúde, do paradoxo epidemiológico e de uma mudança paradigmática na visão sobre o processo saúde e doença.

Buscando compreender as justificativas ao invés de julgá-las (corretas, incorretas, infundadas ou persecutórias), as contribuições da história da vacinação revelam não só êxitos técnico-científicos e epidemiológicos, mas também tropeços. A contrapelo dos sucessos, serão relatados a seguir alguns exemplos de pedras no meio desse caminho tortuoso. A primeira vacina desenvolvida por Jenner foi contra o vírus da varíola, onde ele pegava a pústula de vacas com varíola bovina, aplicava em alguma criança, após oito dias aplicava a pústula dessa criança fonte no braço de outras crianças, e assim por diante, numa técnica braço-a-braço (Plotkin et al., 2008). Pela característica rudimentar, muitas dessas vacinas contra varíola existentes do século XVIII ao XIX levaram à morte da pessoa pelo próprio vírus da varíola, além de sepse 
por contaminação da pústula com alguma bactéria ou transmissão de outras doenças, como foi o caso da Itália, que em 1861, 41 crianças contraíram sífilis devido à contaminação da pústula com sangue de uma criança com a doença (Offit, 2008).

No final do século XIX, Pasteur desenvolveu a vacina contra o vírus da raiva e, após seu estudo em cães, começou a aplicá-la em humanos e observou que de cada 200 pessoas vacinadas, 1 ficava paralítica e depois morria. A morte foi compreendida $a$ posteriori, pela presença de mielina do cérebro dos coelhos de onde ele cultivava e extraía o vírus da raiva, gerando em algumas pessoas uma reação autoimune (Offit, 2008; Plotkin et al., 2008).

Em relação às questões de ordem ética, entre as décadas de 1930 e 1960, as vacinas, após os estudos feitos em animais, eram inicialmente testadas em crianças com necessidades especiais ou em filhos de mães prisioneiras. Apesar disso ser aceito eticamente pela maioria das pessoas antes da Declaração de Helsinque em 1964 que regulamentou a experiência em seres humanos, não excluía movimentos sociais de resistência ou contra tais práticas (Offit, 2008).

Já na segunda metade do século XX, Jonas Salk produziu a vacina inativada contra a poliomielite, e após teste em crianças mostrando que ela funcionava, repassou a tecnologia para cinco empresas nos EUA para produzi-la. Uma dessas empresas produziu de forma errada, culminando na produção de uma vacina com o vírus da pólio ativo. Mais de cem mil crianças foram vacinadas com essa vacina no país, causando doença leve em setenta mil, paralisia permanente em 200 e matando 10 crianças. Outro exemplo ocorrido nessa época foi a vacina contra o sarampo. As primeiras levas eram muito reatogênicas, e causavam na maioria das crianças febre alta (às vezes levando a convulsões) e lesões semelhantes à própria doença (Offit, 2008; Plotkin et al., 2008).

Além disso, o controle de pureza dessas primeiras vacinas era limitado ao arsenal tecnológico da época. A vacina contra sarampo era (e é até hoje) realizada em embrião de galinha. Parte da primeira leva de vacinas contra sarampo nos anos 1950 foi feita em ovos de galinha contaminados pelo vírus da leucemia do frango, um vírus que causa tumor em frangos, mas não no homem. Uma parcela das vacinas contra pólio, tanto as produzidas por Salk quanto as desenvolvidas por Sabin, estavam contaminadas pelo vírus SV40 que causava câncer em animais - uma vez que essas vacinas eram feitas de rins de macacos - e no momento dessa descoberta, mais de dezenas de milhões 
de crianças já haviam sido vacinadas. Até os cientistas terem certeza e confirmarem que ambos os vírus não causavam câncer no ser humano, foi um período de grande apreensão diante do desconhecido (Offit, 2008; Plotkin et al., 2008).

No Brasil, em novembro de 1960, na cidade de Fortaleza/CE, 18 pessoas que receberam uma vacina contra raiva morreram com sintomas da doença. A investigação mostrou falha na produção da vacina, contendo vírus da raiva com virulência. Esse trágico episódio proporcionou a revisão da produção dessa vacina em laboratórios localizados no Brasil e em diversos países no mundo (Pará, 1965; Plotkin et al., 2008).

Temendo doenças de animais no homem, nas décadas de 1970 e 1980 algumas vacinas foram desenvolvidas em fetos humanos, o que, por sua vez, gerou enorme desconforto pela questão ética envolvida. Outra história controversa foi a vacina contra a hepatite B, que na década de 1970 foi realizada a partir de sangue humano de homens homossexuais e usuários de drogas - grupo de maior risco para essa infecção naquele momento nos EUA. Os primeiros testes dessa vacina sofreram enorme resistência da população e surgiu boatos que foi essa vacina que teria introduzido o HIV nos EUA (hipótese descartada a posteriori). Mesmo com técnicas de purificação mais avançadas, o advento do HIV/AIDS fez com que a vacina contra hepatite B feita de sangue humano caísse por terra, ficando no mercado apenas entre 1981 a 1986 (Offit, 2008; Plotkin et al., 2008).

Outro exemplo é a primeira vacina contra o rotavírus, chamada RotaShield, que foi licenciada nos EUA em 1998 e retirada do mercado 1 ano após, pela associação com casos de intussuscepção intestinal (invaginação de uma parte anterior do intestino em uma posterior, podendo levar à obstrução intestinal, por vezes com necessidade de resolução cirúrgica) (Plotkin et al., 2008).

Assim, o medo dos efeitos adversos graves, a percepção de que a vacina possa causar a doença que ela almeja proteger, até medos de que ela possa promover câncer e doença autoimune podem ter sido acessados por informações da internet que remetam aos obstáculos do passado. Os tropeços sofridos na história da vacinação parecem ter mudado de face na atualidade, marcada por um cenário de grande investimento das indústrias farmacêuticas e com o desenvolvimento de tecnologias mais rebuscadas e seguras como a engenharia genética e o controle de qualidade bioquímico e bacteriológico, entre outros avanços. 
Paradoxalmente, é diante dos progressivos avanços científico-tecnológico na área que se encontra a diminuição da aceitabilidade das vacinas por grupos específicos em diversos países e no Brasil. Uma hipótese é que esse avanço contemporâneo traz repercussões conflitantes por agregar, ao mesmo tempo, o valor positivo por ter uma tecnologia nova e moderna legitimada pela ciência, e o medo do novo e do desconhecido, por estar diante da insegurança frente às possíveis repercussões no futuro em saúde, como presente nos relatos dos pais que afirmaram ter medo dos efeitos adversos a médio e longo prazos, que ainda não são conhecidos pela ciência; ou medo das vacinas novas, que não têm o respaldo da tradição ou da experiência a longo prazo.

Já no que diz respeito às características das estratégicas populacionais em massa, como a vacinação infantil universal, conforme o alvo ou a meta, elas podem promover impactos mais significativos quando comparadas às intervenções de base individual e localizadas, dirigidas aos grupos de maior risco (Rose, 2010). "Contudo, as intervenções de amplitude populacional apresentam uma certeza de causalidade muito menor - com relação às exposições populacionais - quando comparadas às exposições individuais" (Rose, 2010: 48). Assim, essa qualidade das medidas populacionais faz com que aumente o distanciamento da percepção de causalidade da medida preventiva, aumentando a possibilidade de descrença ou questionamento. O abismo que separa a percepção da informação dada por estudos epidemiológicos ou pelo profissional de saúde é patente, "pois é improvável que um risco que não se materializou dentro da própria existência individual seja considerado seriamente” (Rose, 2010: 76).

Ademais, quando a vacinação é dada em massa e a doença fica controlada, há uma proteção geral, mas não é possível identificar os indivíduos que foram diretamente beneficiados, ou seja, muitos precisam ser vacinados para se prevenir da doença ou morte em alguns, pois não é possível prever ou saber quais seriam os sujeitos acometidos. O mesmo não ocorre com os que sofreram efeitos adversos à vacinação, que são facilmente identificados. A prevenção coletiva dada estatisticamente é diferente do efeito colateral da vacinação, que incide no indivíduo, corporalmente (Rose, 2010). Isso foi o que Rose chamou de paradoxo da prevenção, "a medida preventiva que traz. grandes benefícios à comunidade oferece pouco para cada indivíduo participante" (Rose, 2010: 66; grifo do autor). Essas características podem ajudar a explicar, pelo menos em parte, a sensação de pouco sentido atribuído ao calendário básico infantil no 
Brasil, compreendido como extenso para alguns casais entrevistados, uma vez que eles não se sentem ameaçados por essas doenças imunopreveníveis.

No tocante ao paradoxo epidemiológico, o êxito dos programas de imunização em geral, e em especial do PNI, por sua abrangência e efetividade, conduziu a uma situação de controle das doenças imunopreveníveis e, em contrapartida, à maior visibilidade dos efeitos adversos das vacinas (Bedford; Elliman, 2000). Tal ambiguidade pode ter gerado, em grupos particulares, como visto em relatos de alguns pais, a sensação de controle epidemiológico das doenças preveníveis por vacina, a concepção de que estas doenças são leves ou benignas e o medo adverso dos imunobiológicos. É também nesse cenário do paradoxo epidemiológico, com a percepção de controle das doenças, que o calendário de vacinação estabelecido no Brasil soa para alguns casais como excessivo ou um exagero, e assim, desnecessário.

Por fim, na fala de alguns entrevistados aparece a busca por uma saúde que rompe em parte com o horizonte normativo de tratar, curar, corrigir distúrbios (Ayres, 2003) da medicina tecnológica (Schraiber, 2008), vista por eles como excessiva e intervencionista. Influenciados por profissionais humanizados, homeopatas e antroposóficos, e pela maternidade ativa e parto humanizado, para alguns desses participantes, a composição da vacina, seu mecanismo de ação e a existência de vacinas para doenças que eles consideram leves e benignas (como gripe e rotavírus) não faz sentido para o que eles concebem como saúde do filho, em que sua criança vai ficar forte e conseguir enfrentar as doenças infantis no seu percurso de vida com amor parental, harmonia familiar, amamentação prolongada, boa alimentação (como alimentos orgânicos) etc. Para eles, não só a imunidade gerada pela doença é melhor que a pela vacina, mas a vacina pode gerar um desequilíbrio na imunidade natural da criança.

A difusão da informação em saúde pela internet aproximando mundos diversos, e diante desse universo constituído pela memória simbólica dos pontos negativos da história pregressa da vacinação, pelo paradoxo da prevenção e epidemiológico e pela ruptura paradigmática do processo saúde-doença-intervenção, fortalecidos por profissionais que difundem que a vacinação infantil deve ser uma escolha singularizada, esses pais conformaram valores opostos de risco e proteção aos que tradicionalmente são vinculados às vacinas pela biomedicina e pela saúde pública e coletiva. 


\subsection{A vacinação infantil: entre o risco e a proteção}

Esse subcapítulo busca compreender a percepção do risco individual e coletivo das doenças imunopreveníveis e das vacinas dos casais entrevistados, por meio de uma interlocução com a concepção de risco na epidemiologia e, de forma mais ampla, na sociedade complexa contemporânea.

Os valores atribuídos à vacinação infantil variaram conforme o grupo estudado. Como já relatado anteriormente, os casais que vacinaram seus filhos e alguns dos que selecionaram associaram à vacina o valor de proteção contra a ameaça de doenças imunopreveníveis no âmbito da saúde e como parte integrante do exercício parental. Já os casais que não vacinaram os filhos, todo o processo vivido, principalmente pelas mulheres (a tomada de decisão em (não) vacinar os filhos, as concepções acerca da vacinação e o manejo dessa escolha no âmbito da família e do círculo social), conformaram ressignificados em termos de proteção e risco, em que a vacina passa a assumir um valor de risco e ameaça ao filho, e exercício parental nesses casos é proteger a criança da vacinação.

E para mim, acho que para o Alessandro também, a vacina é uma proteção, é um cuidado que a gente tem com ela e que protege ela de coisas piores (Eduarda, que vacinou a filha).

Eu falei [para o marido] 'Não sei, se quiser, mas agora, aqui, acho que não tem necessidade de vacinar. Ela está mais protegida assim' (Amanda, que não vacinou a filha).

A única coisa é que eu agradeço, é não saber o que eu sei hoje, quando dei vacina nos meus filhos. Se eu soubesse aí eu não ia conseguir dar. Então assim, por isso esse dilema, das vacinas que eu dei para Kelly [ $1^{\mathrm{a}}$ filha], que eu não quero dar para Pedro [ $2^{\circ}$ filho], porque eu acho que ela, eu expus ela a um risco que não era necessário. Tem uma certa neurose 'ah, vacina de tudo!' Um monte de vacina particular e tudo mais. De coisas que não, nem hoje corre o risco de ter, um monte de coisas assim. Mas eu nunca tinha pensado nisso (Paula, que não vacinou o segundo filho). 
Aí conversei com o homeopata que hoje em dia é o nosso homeopata, aqui em São Paulo, e ele falou para mim assim:

- Olha, você acha que uma tartaruga vai cair na sua cabeça?

- Imagina! Tartaruga cair na minha cabeça? Nunca!

- Nunca? Será que nunca mesmo? Pensa bem. Saiu um avião sei lá de onde, transportando tartarugas para levar para um estudo não sei onde. Pode ser que caia, você não acha?

$-\mathrm{Ah} . .$. Mas será?

- Você não sabe, mas e se acontecer? Por que você não compra um capacete? Você anda de capacete para cima e para baixo, para evitar, né?

- Que loucura! Que papo louco é esse...

Mas a vacina é mais ou menos isso, você não sabe se seu filho pode pegar. Você vai dar por causa disso? Por que 'quem sabe?' E eu fiquei, nossa, não sei se isso é uma boa analogia, mas pensando bem é mais ou menos isso (Clara, que não vacinou as filhas).

Apesar da aparente diversidade de valores atribuídos às vacinas por esses participantes dentro do espectro entre a proteção e o risco, a construção de projetos que engloba planejamento e desejo de controle biográfico característico da camada média urbana (Velho, 1994) aproxima-os, uma vez que sobressaiu, na maioria dos casais, a prática de gestão individual do risco e o desejo de controle do risco. O que divergiu foi a percepção, interpretação e manejo do risco e não seu desejo de controle: para os casais que vacinaram, a vacinação infantil era um recurso disponível e legitimado para o controle de doenças que poderiam afligir o filho, ou seja, a vacinação seria um meio de controlar o risco das doenças imunopreveníveis; e para os que não vacinaram, nãovacinar era um caminho para proteger o filho do risco da vacinação, cujo controle do risco, também vivenciado e valorado, se dava às avessas.

Percebe-se, nos pais que não vacinaram, três principais concepções frente ao risco: a primeira, de que os filhos têm pouco risco de contrair as doenças preveníveis pela vacina, já que a doença está controlada; a segunda, que o risco maior é dos efeitos adversos à vacinação; e a terceira, que o risco de contrair uma doença prevenível por vacina vai depender do local e das condições de vida de cada pessoa (se faz parte ou não de determinado grupo de risco). O depoimento a seguir aborda esse último fato. 
Se eu tenho, eu faço parte de um grupo de risco, por causa da região que eu moro, meu trabalho, do meu histórico familiar, por um monte de coisas, acho melhor eu tomar vacina. $\mathrm{O}$ meu risco tomando vacina é menor, então eu vou tomar. Ah, eu não sou igual a você. A minha alimentação é diferente, a minha história de vida é diferente, minha família. Eu moro em outra região, então eu não preciso tomar. Devia ser assim (Paula).

As três concepções de risco se apoiam na lógica epidemiológica. Esses pais que não vacinaram seus filhos instrumentalizaram-se e apropriaram-se de dados oriundos de estudos epidemiológicos, logo quantitativos e de enfoque probabilístico, relativos aos coeficientes de incidência ou prevalência de doenças preveníveis por vacinas e aos conceitos de eficácia, eficiência, efetividade e segurança, porém, os transportam, ressignificando-os a uma percepção de risco de ordem subjetiva, que vai interferir, dentro do campo de possibilidades explorado por Velho (1987, 1994), nas escolhas e construção de projetos "individuais", que são partilhados por grupos sociais mais amplos, com identidades culturais semelhantes (como por exemplo, os adeptos da maternidade ativa, da homeopatia etc.), que defendem que vacinar ou não deve ser uma escolha do âmbito individual e privado, e incitam à problematização da vacinação.

A epidemiologia incorporou o conceito de risco. Esse conceito sofreu transformações de ordem conceitual e discursiva ao longo do tempo nessa disciplina (Ayres, 2008). Entre 1930 a 1945, na denominada "epidemiologia da exposição", predominaram os estudos sobre as doenças infectocontagiosas e ocorreu a aproximação da disciplina com as ciências biomédicas, na intermediação de ordem teórica entre os fenômenos orgânicos e os coletivos em saúde. Foi na "epidemiologia da exposição" que a ideia de risco foi incorporada, atrelada ao conceito de suscetibilidade. O risco, neste momento, passa a "constituir um conceito essencialmente analítico, referido às condições de suscetibilidade individual determinantes do comportamento epidêmico das doenças infecciosas" (Ayres, 2008: 293; grifos do autor). Em meados do século XX, o autor identifica a passagem da "epidemiologia da exposição" para a "epidemiologia do risco", com o advento sobretudo dos estudos das doenças não transmissíveis, os quais buscaram (e buscam) identificar os fatores de riscos (exposição) envolvidos em diversos desfechos. Neste momento, o conceito de risco é validado por meio da matemática, pela inferência estatístico-probabilística: 
A retórica do "estar sob risco" ("at risk") não faz mais qualquer sentido na semântica da associabilidade, e essa construção linguística vai mesmo progressivamente rareando na literatura epidemiológica. Ela vem sendo substituída pela construção "dado $x$ o risco é $y$ " (the risk of... is"). Não se está "sob risco"; o risco não é encontrado, ele é formulado; não se identifica o risco, atribui-se um risco. O risco não é mais um qualificador do caráter coletivo e quase-atual de um mau-destino, ele é, imediatamente, expressão formal e probabilística do comportamento de frequências de determinados eventos de saúde quando inquiridos a respeito de associações particulares (Ayres, 2008: 281).

Apesar desses pais apoiarem a argumentação dos seus depoimentos em dados epidemiológicos, é importante situar que a ideia de risco epidemiológico se distingue da interpretação dada pela população leiga. No primeiro, o risco remete a um dado quantitativo, objetivo, impessoal; é uma entidade de "existência autônoma", que "adquire um estatuto ontológico" (Castiel et al., 2010: 25). Já a leitura da população leiga aos riscos epidemiológicos é condicionada ao contexto sociocultural vivenciado subjetivamente.

O risco é uma ameaça ou um perigo objetivo que existe e pode ser medido independentemente de processos sociais e culturais, mas pode ser distorcido ou enviesado por meio de estruturas sociais e culturais de interpretação (Lupton, $2004^{20}$; apud Castiel et al., 2010: 44).

Assim, o sucesso das vacinas e dos programas de imunização, associado à maior visibilidade dos efeitos adversos das vacinas, corroborou para a construção de concepções, por parte de alguns pais, sobre risco e proteção, opostas às que tradicionalmente são vinculadas às vacinas. É no suporte matematizado da concepção de pouco risco de contágio das doenças preveníveis por vacina e, por conseguinte, um risco maior dos seus efeitos adversos, balizado na legitimidade epidemiológica de validade probabilística, que suporta o sentimento "invertido" de risco e proteção entre os pais que vacinaram e os que não o fizeram.

Se os dados epidemiológicos apontam para a segurança das vacinas, por que alguns pais têm tanto medo delas? Por que aquele risco tido como ínfimo ou irrisório pela epidemiologia e pela biomedicina se transforma em enorme e potente ameaça à

\footnotetext{
${ }^{20}$ Lupton D. Risk. London: Routledge, 2004.
} 
saúde do filho por esses pais? Castiel et al. (2010: 59) ajudam a responder: partindo-se de uma leitura que o risco é também socialmente construído, que pode ter permanências e modificações de significado conforme o tempo e o espaço, as percepções e "decisões humanas podem pautar-se em outra lógica que não a epidemiológica”. Segundo os autores:

Ainda que a lógica epidemiológica possa servir de referência para algumas decisões humanas, a estratificação social, a pluralidade cultural e a subjetividade concorrem para a multiplicidade de percepções, significados e atitudes diante do risco. Basta dizer que, em alguns momentos, as pessoas valemse da inconstância e da ambiguidade das recomendações da saúde pública para justificar a recusa em adotá-las (Castiel et al., 2010: 60).

Pode-se, então, dizer que o tiro saiu pela culatra? A epidemiologia e a saúde coletiva/pública são reféns de seus próprios sucessos? São estas ambiguidades e tensões que denunciam a importância de compreender esse fenômeno de inversão de valores à vacina, de risco e proteção, num contexto social mais amplo, para além das esferas da epidemiologia, da biomedicina e da saúde pública.

A lógica de risco extrapolou os contextos de saúde, médicos e epidemiológicos. Na contemporaneidade, ela alcança a vida íntima e familiar das pessoas e é difundida e explorada pela mídia, internet e redes sociais. A ideia de risco penetrou na vida privada das pessoas e se instaurou uma atmosfera "riscofóbica" (Castiel et al., 2010). Para além do aumento em número e qualidade dos riscos na sociedade, ele passou a se configurar um ethos contemporâneo, em que a relação entre os indivíduos e o mundo em que vivem se estabelece, não exclusivamente mas também, por meio do risco (Beck, 2010).

Para tanto, faz-se necessário compreender qual e como o conceito de risco está enraizado na sociedade contemporânea. Beck (2010) lançou seu livro na Alemanha Ocidental em 1986, intitulado "Sociedade de risco". Nele o autor explora as transformações que a modernização trouxe à sociedade industrial clássica do século XIX, em outra configuração social que ele denominou "sociedade de risco", situada a partir das últimas décadas do século XX. Nela, a produção social de riqueza vem atrelada à "produção, definição e distribuição de riscos científico-tecnologicamente produzidos" (Beck, 2010: 23). Tendo como pano de fundo catástrofes naturais e humanas, como Chernobyl, o advento da bomba e energia nuclear, a poluição do solo, 
da água e do ar pela industrialização etc., o autor defende que a sociedade passa a fundamentar-se em torno da lógica e distribuição de risco, desde a produção até a percepção de risco. Diferente das ameaças que perseguiram a história da humanidade, "risco é um conceito moderno, ele pressupõe decisões humanas, futuros humanamente produzidos (probabilidade, tecnologia, modernização)" (Beck, 2010: 362; grifo do autor). Assim, o risco engloba tanto uma dimensão teórica - legitimada pela ciência quanto normativa. Nos dias atuais, sem precedentes na história, a concepção de risco extrapola para dimensões ecológicas, financeiras, militares, terroristas, bioquímicas, informacionais e de saúde, sendo vivenciada como onipresente (Beck, 2010).

Para o autor, a ideia de risco é um constructo sócio histórico de uma antecipação do futuro de danos previsíveis no presente, mas que são vividos como reais. O risco se constrói na confluência da existência de técnicas de visualização, do seu alcance simbólico e da sua divulgação em meios de comunicação em massa. É a consciência do risco que define sua existência, e assim, o conhecimento sobre ele assume um lugar de destaque. E para que o risco exista, ele tem que ser acreditado, uma vez que em grande proporção ele é invisível e intangível. Porém, o fato do risco poder escapar à percepção não o torna menos real, nem inexistente, ao contrário, isso aguça a concretude do perigo.

A superprodução de riscos, social e institucionalmente construídos, fomentam o mercado financeiro, que se produz simultaneamente os riscos e os recursos contra os riscos, num mercado que se auto alimenta. Diante da insegurança e do medo gerados, surgem novas oportunidades de mercado, os consumidores e os que lucram com os riscos. Com a pluralização dos riscos se intensifica a comercialização dos riscos. Além da questão mercadológica marcante, a onipresença dos riscos remodela os referenciais de (a)normalidade, onde situações de exceção são vivenciadas como estados normais da modernização da sociedade.

Se a construção do risco está no domínio da racionalidade da ciência, que por meio de especulações e cálculos probabilísticos determinam o risco do risco, este por sua vez, é vivenciado de forma distinta pelos diferentes sujeitos. Beck (2010) fez uma importante distinção entre os riscos estipulados cientificamente e a percepção deles pela população. Em sendo uma construção sócio histórica, o risco e sua percepção podem se tornar questionáveis, se transformar, se redefinir, ou serem descartados. Uma 
característica da "sociedade de risco" é que, a despeito das diferenças sociais de classe, gênero, geração, raça, etc., conforme a dimensão do risco - principalmente no caso de um risco global - ele pode alcançar um lugar compartilhado pelas pessoas, um lugar que diz respeito a um conjunto de sujeitos num mundo de risco. Apesar dessa partilha de algo comum, há uma subjetivação dos riscos que está no âmbito do sujeito.

Por fim, Beck (2010) sugere que, além da "sociedade de risco", viver os efeitos colaterais da modernização, que se voltaram à humanidade sob forma de perigo e ameaça (como a mudança climática, as crises financeiras, o terrorismo etc.), o risco se tornou uma categoria norteadora e organizadora tanto na esfera social mais ampla quanto na privada. E é na lógica mediada pelo risco que se expande o princípio da precaução pela prevenção. Diante disso, os riscos na contemporaneidade não só aumentam quantitativamente, mas também se diversificam qualitativamente, sob novos formatos de risco individual que, por sua vez, geram demandas de prevenção e aguçam a culpabilização frente a posturas contra hegemônicas.

A seguir, serão explorados a proposta de aproximação dialógica entre os lugares do risco no contexto contemporâneo e o universo da vacinação e seus valores paradoxais de risco e proteção pelos participantes deste estudo. Para iniciar a discussão, faz-se importante contextualizar o cenário da incidência e prevalência das doenças imunopreveníveis por vacina de outrora com o do atual. As gerações que vivenciaram, antes da implementação das vacinas em massa, a disseminação de algumas doenças preveníveis por vacina, de elevada morbimortalidade no Brasil, como a poliomielite, febre amarela, sarampo, coqueluche, difteria, tétano neonatal, meningite etc., sobretudo antes das décadas de 1970/80, a vacinação agrega valor de saúde e proteção às crianças. Ressalte-se que os casais entrevistados neste estudo fazem parte da coorte de nascidos nestas décadas e foram imunizados quando crianças. Se para Beck (2010), a existência do risco se consolida pela consciência dele, o fenômeno recente de controle das doenças pela vacinas faz com que as morbidades se tornem "invisíveis" no momento atual, e assim, na percepção de algumas pessoas, o risco da doença torna-se irrelevante, não justificando para eles a necessidade de uma intervenção invasiva como prevenção de algo que não é vivenciado como um risco real.

Outra dimensão colocada por Beck (2010) refere-se a subjetividade do risco, que mesmo ele sendo global, podendo ser manipulado pelo mercado e ser norteado por uma 
racionalidade científica, o risco é percebido conforme uma outra lógica subjetiva do indivíduo. Essa subjetividade, por vezes dissociada da premissa científica, pode explicar em parte as diferentes posições dos pais frente a algumas doenças como rotavírus, gripe, varicela, rubéola etc. e, de maneira semelhante, frente aos compostos presentes nas vacinas. Por mais que tenha um peso grande na questão do nível de informação entre os casais que vacinaram e os que não vacinaram, diante de uma situação fictícia em que ambos detenham os conhecimentos das doenças e das vacinas, o risco vivenciado por eles é muito diverso: para os que vacinaram, as vacinas protegem contra o risco dessas doenças que podem ter complicações graves e o risco à saúde pelos compostos na vacina são baixos, dentro dos padrões e limites de segurança estabelecidos por especialistas; e para os pais que não vacinaram, essas doenças não alcançam o patamar de risco ao filho por serem "leves", porém, os compostos das vacinas, a despeito da racionalidade científica, são ameaças vivenciadas como reais. $\mathrm{O}$ mesmo pode ser dito com as vacinas polivalentes, que agregam diversas vacinas em uma mesma aplicação. Para uns ela é um diferencial por combater muitas doenças de uma vez só, ou seja, uma arma de proteção contra muitos riscos; e para outros, ela é uma bomba de risco à saúde.

As produções de risco não são isentas de interesse e manipulação, como Beck (2010) salientou, por meio do peso mercadológico na superprodução de riscos. Daí a opinião de muitos pais que não vacinaram, que denunciaram o viés das indústrias farmacêuticas na luta de poder e na construção de uma situação de risco que para eles é irreal, uma vez que elas almejam o lucro e não o bem estar e a saúde. O mercado pode influenciar na divulgação e na manipulação da importância do risco. Isso no campo das vacinas é uma realidade, como pode ser visto nos patrocínios dessas indústrias nos congressos médicos pediátricos e de infectopediatria, a soberania das indústrias de vacinas, "o grande filão" na atualidade na área. Mas isso também foi visto no cenário oposto, no patrocínio que Wakefield et al. recebeu de um advogado, Richard Barr, com a intenção de aumentar processos contra indústrias farmacêuticas que fabricavam vacinas, no clássico trabalho fraudulento que forjou a associação da vacina MMR com autismo (Godlee et al., 2011).

Ademais, Beck defende que "o efeito social das definições de risco não depende portanto de sua solidez científica" (2010: 38). O avanço científico-tecnológico e a crescente conscientização do risco vêm acompanhados por uma reação tecnofóbica de 
uma parcela da sociedade. No caso da vacinação, isso pode ser demonstrado pelo descompasso entre os avanços científicos da biomedicina no campo das vacinas e os dados epidemiológicos que mostram êxito no controle de doenças e queda da morbimortalidade; e a reação de uma parcela da população estudada contrária a essa prática; ou também com o medo ainda muito presente do autismo associado à vacina MMR, mesmo com as evidências científicas que mostraram o contrário. A diferenciação do risco definido cientificamente e a percepção social dele denunciam a fragilidade e o distanciamento dialógico das ações da medicina preventiva e da saúde pública fundada no repasse de informações em saúde aos usuários (como malefícios do fumo, benefícios de uma alimentação saudável, atividade física etc.), no reducionismo interpretativo de que o sucesso da ação preventiva é um mero problema de informação. No caso da vacina, este estudo mostrou justamente o contrário: os pais que vacinaram estavam tranquilos diante de uma prática e cultura de vacinação, que pouco se fez presente a necessidade de busca por informações; e os que não vacinaram, a informação foi decisória para uma mudança de postura.

Há, por sua vez, uma sintonia entre a lógica do risco e a lógica da vacina. Ambos tratam de uma antecipação do futuro de algo previsto no presente. Vacina-se uma criança hoje para prevenir uma possível doença no futuro, que ela pode ou não ter contato ao longo de sua vida. Essa conformação de risco é vivida como algo real pelos pais que vacinaram seus filhos, e faz pouco sentido para os que não vacinaram, pois estes não vivenciam a possível ameaça das doenças, apenas a da vacina. A própria projeção ao futuro inerente ao conceito de risco agrega, para além da subjetividade, a possibilidade de ele ser experimentado como real e irreal por diferentes pessoas.

Outra semelhança é que os riscos de um modo mais amplo (como o caso na energia nuclear) e os riscos epidemiologicamente atribuídos às doenças preveníveis por vacina são quantificados probabilisticamente, em que um risco pequeno pode gerar uma consequência devastadora, ou melhor, onde a proporção de risco e potencial catastrófico não necessariamente andam sincronizados. A periculosidade está não no grau do risco mas no seu efeito destruidor. Isso, por sua vez, escapa da percepção de alguns pais que não vacinaram seus filhos. Eles partem do pressuposto que o risco do filho pegar o vírus da poliomielite ou do sarampo, por exemplo, é muito baixo, mas não levam em consideração que o retorno da circulação desses vírus na população por uma queda da 
cobertura vacinal e o perigo para seu próprio filho, por mais que isso seja pouco provável, pode levar a consequências gravíssimas.

Além disso, outra sintonia entre o risco e a vacinação é que ambos são propulsionados pelo medo. Há uma "solidariedade do medo", vivida pelos pais que vacinaram pelo medo da doença e da morte e pelos pais que não vacinaram pelo medo da vacina, da morte ou dano ao filho. Diante do sentimento de medo, a experimentação da vivência do risco é tão real - quanto o risco oriundo da vacinação descrita pelos que não vacinaram - que ele se torna real para essas pessoas, independente do que se alega cientificamente. É o medo e o desamparo que favorecem correntes contrárias, radicais ou extremistas.

Essa lógica do risco normatizado pela ciência produz uma questão. Aquilo que até então não foi reconhecido cientificamente como risco, é tratado como inexistente. No caso das vacinas, ainda não se sabe os possíveis efeitos a médio e longo prazo dessa prática, uma vez que ela é aplicada em massa de forma coordenada há apenas quatro décadas no Brasil (com a criação do PNI), e se levar em conta a introdução de vacinas com tecnologias mais novas, tem menos tempo ainda. Diante de uma parcela de pessoas que expressam uma corrente tecnofóbica, o fato de estudos científicos dizerem que há ou não risco até o momento, não se pode descartar essa possibilidade. Essa incerteza parece perseguir os pais que não vacinaram os filhos deste estudo.

Buscando um diálogo entre a "sociedade de risco" de Beck (2010) e os estudos de Velho $(1987,1994)$ - que destacou a característica marcante da individualização nas camadas médias urbanas, cujas escolhas e projetos individuais se moldam diante de um campo de possibilidades - é possível problematizar quão autoral e autônomo são as escolhas individuais balizadas num modus operandi cuja relação com o mundo se conforma a partir do risco. Apesar de tão patente nas falas desses participantes que suas escolhas são percebidas, concebidas e vivenciadas como individuais e biográficas; se parte delas são balizadas conforme o medo do risco sócio historicamente construído, até que ponto esses riscos podem influenciar ou interditar essas escolhas? As escolhas vividas como individuais podem sofrer influências e vestígios conforme a subjetividade, susceptibilidade e percepção de determinados riscos pelos sujeitos, relativizando a singularização desse processo. 
Por fim, a imunização é uma prática consagrada pela biomedicina e pela saúde pública brasileira e mundial, mas sua história foi permeada por processos socioculturais mais amplos, e revelou múltiplas facetas e contrastes, que não podem ser desconsiderados ou simplificados, como o reducionismo polarizador ou extremo a favor ou contra. A incorporação da perspectiva socioantropológica, para além de lidar a questão em termos de aceitabilidade, pode contribuir para a compreensão do fenômeno da (não) vacinação de forma mais próxima aos sujeitos e às ações sociais. Assim, a história pregressa da vacinação, o sucesso das vacinas e êxito dos programas de imunização, a maior visibilidade dos efeitos adversos das vacinas, a sensação de controle das doenças imunopreveníveis e a ampliação das informações em saúde via internet, norteada ou não por profissionais de linhas contra-hegemônicas, proporcionaram diferentes concepções acerca da interface no cuidado infantil e (não) vacinação, no exercício parental, e, por sua vez, culminaram na (re)definição de valores sobre risco e proteção, diante de um processo social mais amplo e ordenado também pela concepção de risco. 


\section{A (NÃO) VACINAÇÃO INFANTIL NA VIDA PRIVADA}

No percurso de compreender como se conforma o cuidado infantil e a escolha pela (não) vacinação entre casais de camada média urbana e de alta escolaridade de São Paulo, além das dimensões da tomada de decisão em (não) vacinar pelos pais e concepções sobre vacinação na esfera do cuidado infantil, torna-se relevante apreender como esses processos se configuraram no interior da família.

Considerando que as decisões parentais no cuidado em saúde do filho ocorrem no âmbito privado, esse capítulo busca acessar as convergências e divergências nas relações de gênero e de geração no locus familiar para compreender, de forma mais profunda, o modo como esse segmento social expressa suas escolhas e ações na intimidade doméstica, em especial, no que tange o cuidado em saúde e a vacinação infantil.

A ideia de ter filho foi experimentada pelos casais entrevistados por meio de uma construção balizada principalmente por dois pilares, o planejamento e desejo de controle da reprodução e da parentalidade e o lugar central que a criança assume na conformação dessas famílias. A criança, assim, faz parte do projeto de família para esses casais que, por conseguinte, vai reposicionar as relações familiares. Mesmo nos poucos casais em que a gravidez aconteceu sem programação prévia, a mesma atitude de planejamento e controle foi relatada após a descoberta. Em primeiro lugar, a lógica do planejamento na esfera reprodutiva, assim como em outros aspectos da vida, reflete a própria maneira de se colocar no mundo, típica do universo das camadas médias urbanas nas sociedades complexas contemporâneas (Velho, 1987, 1994). Velho, ao estudar as famílias de camada média em Copacabana no Rio de Janeiro, ressaltou que o processo de individualização social está fortemente enraizado no ambiente privado dessas famílias e é expresso, sobretudo, na valorização da biografia, desenhada a partir da construção de projetos.

A decisão de ter filho foi um pouco balizada pelas outras coisas da minha vida, no sentido de eu falar assim 'bom, deixa eu deixar tudo redondo'. (...) É acho que foi isso, então já vinha esse planejamento e na hora que essas coisas foram acontecendo, então ele veio trabalhar aqui e o mestrado se concluiu, ai então a gente falou 'bom, agora', a gente reformou a 
casa também, deu uma ajeitada, falou 'ta então agora vamos para esse novo projeto' (Fernanda, esposa de Bruno, que vacinou).

Estou casado há nove anos e a gente sempre planejou tudo, então desde o nascimento da Bianca, que hoje tem seis anos, foi tudo bem planejado. Então, quando a gente resolveu que queria ter filho, deu tudo certo, três anos depois veio Lucas, então a gente fez meio que programado (Diogo, esposo de Virgínia, que não vacinou).

O desejo de parto normal e as ações femininas para alcançá-lo - o ideal do "belo parto" ${ }^{, 21}$ - fez parte do planejamento dessa fase de vida por parte de algumas mulheres. Esse projeto, porém, sofreu um grande tropeço quando algumas delas tiveram cesáreas, o que gerou diferentes graus de frustração e sofrimento.

O parto não foi o que eu esperava, porque eu esperava o parto normal, queria muito o parto normal, e eu a gravidez inteira fui me preparando. E era uma coisa que para mim era importante, porque para os benefícios pra criança, porque eu acho que essa coisa de fazer muita cesárea no Brasil, então eu sempre fui muito cuidadosa, a escolha da minha médica, já foi uma escolha de uma médica que uma colega minha já tinha tido parto normal com ela, então eu fui sempre cuidando para isso. (...) O que aconteceu é que minha bolsa estourou e eu não tive dilatação nenhuma, então eu fiquei tipo oito horas induzindo o parto normal, tipo na banheira com remédio e tal e tal, mas eu não tive dilatação, e ai a nenê começou a ter taquicardia. (...) Ai eu fiz a cesárea, eu fiquei um pouco triste na hora, um pouco não, fiquei bem triste, fiquei bem chateada por ter feito cesárea, não ter sido normal. (...) Eu lembro que minha mãe entrou no quarto e a neném não tinha chegado, a primeira coisa que eu olhei pra minha mãe e falei "Mãe foi cesárea!", e comecei a chorar, ai minha mãe "não faz mal, o importante é que ela está bem, não se preocupe com isso e tal", mas ficou marcante isso, então os primeiros dias fiquei bem triste de ter sido cesárea, mas depois a gente supera (Fernanda, esposa de Bruno, que vacinou).

Esse planejamento relatado se associa com o ideal da família nuclear ou conjugal moderna, ancorada pelo amor, a afetividade nas relações conjugais e parentais e pela valorização do indivíduo (Singly, 2010), que coloca a criança como figura central

\footnotetext{
${ }^{21}$ Sobre isso ver nota de rodapé 15.
} 
e essencial para a própria conformação familiar, como se o casal sem filhos, fosse menos família.

Bom, o desejo vem devido ao amor, né? Só que, todo mundo para ter um filho, tem que ter amor, e foi o que aconteceu (Diogo, esposo de Virgínia, que não vacinou).

Então, a ideia de ter filho, eu sempre quis ter filho, sempre achei legal. Agora eu com ela tem a nossa história. É uma coisa muito pessoal de querer melhorar o mundo, essa coisa nossa de ajudar o mundo a melhorar. Eu acho que melhorar o mundo, o único caminho certo é com filhos, pessoas felizes, colocar pessoas felizes no mundo (Francisco, esposo de Cláudia, que selecionou).

É na natureza (risos), quer dizer, que vai avançando a idade, estou com 39 anos, a Fernanda com 35, ai a gente tinha o desejo de ter filho, ai ela que puxou, ela "vai ser agora", enfim, ai decidimos ter filho (...) e ai foi tudo bem, tudo dentro do programado. Mas o desejo de ter filho é isso, acho que desejo de fortalecer a família, de ter continuidade, de ter um bebê, de ter uma história, e agora ter um irmão pra ela ou uma irmã, então é isso (Bruno, esposo de Fernanda, que vacinou).

Apesar das diferenças e singularidades de cada casal entrevistado, e para além da classificação analítica conforme a postura em relação à vacinação do filho, eles apresentaram diversas características que os aproximaram no que diz respeito à parentalidade e aos cuidados cotidianos com os filhos. Muitos pais, sobretudo as mulheres, expressaram uma dificuldade inicial no cuidado logo após o nascimento do primeiro filho, alguns descreveram na forma de medo do desconhecido, que foi se diluindo até ficar numa situação vivida e expressada como de tranquilidade. Esses casais colocaram o exercício parental num lugar de aprendizagem permanente, que se constrói a partir da própria vivência. Assim, a parentalidade se edifica numa dimensão do não saber, mesmo diante da pluralidade de informações e normas de como cuidar da criança, numa esfera ancorada na experiência vivida. Isso assumiu maior vigor quando essa vivência foi experimentada corporalmente, como nos casos da gestação, parto e amamentação pelas mulheres. Para ajudar nessa fase inicial do desconhecido, a maioria dos casais tive o apoio de suas mães ou sogras nos primeiros dias, com exceção do 
casal, Eduarda e Alessandro, que contaram com duas auxiliares de enfermagem que se revezaram durante as 24 horas, nos primeiros meses.

O banho foi muito difícil, os primeiros banhos inclusive foi minha mãe que deu, acho que os dois primeiros banhos, porque a gente fica assustado, o bebêzico é muito pequenininho, você não consegue ainda estar confiante de que vai virar pra lá pra cá, a cabecinha, o pescocinho ainda é muito mole e tal, então o banho foi isso, foi difícil, até o dia que eu decidi que não ia ficar virando ela pra lá e pra cá não, eu vou só segurando assim... Porque o hospital ensina um monte de jeitos né, que você tem que virar assim e tal, eu falei 'não, para eu conseguir, vou deixar ela só apoiada assim na minha mão, sem virar, não vou lavar as costinhas, lavo por baixo e tal' (Fernanda, esposa de Bruno, que vacinou).

Eu nunca tive babá até então, fiquei agora há três meses. Esses cuidados é um aprendizado, então o tempo que fiquei no hospital foi muito importante, prestava muita atenção. $\mathrm{O}$ fato da minha cunhada, das minhas duas cunhadas estarem com bebês bem recentes e elas estarem o tempo todo aqui me ajudando foi bem importante. A sogra, a minha sogra, a minha mãe. (...) Mas esses cuidados são feitos com muito carinho. Trocar fralda, delícia, dar banho, delícia. Então tem coisas que faço questão de fazer até hoje. Dar banho, eu chego em casa e dispenso a moça, para brincar com ele, para colocar para dormir. Então é legal, bem legal essa parte assim (Helena, esposa de Guilherme, que vacinou).

Bom, foi... Eu estava ali constantemente. No começo foi uma ansiedade, até as duas primeiras semanas quando minha filha nasceu, era tudo lindo na gravidez, de repente nasce, está na sua mão, você fica 'ah meu Deus, que responsabilidade gigante', então daí foi bem uma montanha russa no começo. E daí eu fazia tudo. Eu tive a minha sogra comigo no começo por duas semanas, em Floripa, ela ficou lá me ajudando. Depois veio a minha mãe, Jonas estava trabalhando bastante já na época que a Maria nasceu. Então, ele trabalhava um horário meio maluco, então chegava em casa meio super tarde e eu ficava com ela. Então no primeiro mês tive bastante ajuda da minha mãe e da minha sogra. Depois eu fui começando a ficar mais sozinha. 
(...) Porque você faz tudo, dá banho, troca fralda, dá mamá (...) E o Jonas à noite, quando ele chegava do trabalho, aí ele me ajudava, como ela acordava à noite bastante, daí trocava fralda à noite, ele tirava ela do bercinho trazia para dar de mamar, mas ficou mais comigo mesmo os cuidados assim. Foi bem intenso (Clara, esposa de Jonas, que não vacinou).

Outro fator que aproximou esses casais foi a amamentação prolongada. Vivida de maneira bem diversa e com graus variados de dificuldade ou facilidades, todas as mulheres entrevistadas amamentaram exclusivamente até o retorno ao trabalho, até a orientação médica de seis meses, ou até quando desejaram (Amanda amamentou exclusivamente até os nove meses); e mantiveram o aleitamento materno complementado com outros alimentos por mais tempo (entre dez meses até seis anos). O lugar de destaque do aleitamento materno nessas famílias, sustentado pela tríade desejo da mulher, apoio do marido e estímulo do pediatra, está em sintonia com estudos na literatura que mostraram uma forte associação entre a prática de amamentação principalmente o aleitamento materno exclusivo - e o nível socioeconômico e a escolaridade materna, onde foram verificadas maiores taxas entre as famílias de alta renda e mães escolarizadas (Escobar et al., 2002; Faleiros et al., 2006; Damião, 2008). Todas as mulheres entrevistadas que necessitaram retornar ao trabalho optaram por tentar ordenhar o leite materno em detrimento de iniciar direto com leite artificial, prática alcançada e sustentada por muitas delas. Duas mães, Sílvia e Paula, restabeleceram o aleitamento materno após desmame precoce por motivo de saúde dos bebês, prematuridade e cirurgia gástrica ao nascimento, respectivamente. Uma mãe, Virgínia, ainda amamenta a primeira filha de seis anos, quando ela pede, junto com seu segundo filho de três anos.

Teve uma coisa que me impactou bastante, porque eu tinha leite no início, mas ele era muito pequeno, então não conseguia mamar. E depois disso, com a minha ansiedade eu parei de amamentá-lo, foi uma loucura. (...) Ele tomou leite artificial, isso muda o cocô, não gostava disso e aí a minha sogra veio nos visitar quando ele estava fazendo quatro meses e me trouxe uma bomba elétrica, que foi o melhor presente que eu ganhei na vida e eu me tranquei durante uns dois dias com ela e voltei a produzir leite. Então, amamentei o Antônio que era isso que eu estava mais preocupada. Então, depois que eu consegui voltar a amamentar, consegui amamentar exclusivamente durante três 
meses e aí voltei a trabalhar quando ele estava com seis meses (Sílvia, esposa de Hugo, que selecionou).

Tanto para o parto quanto para a questão da amamentação, que hoje ela tem essa participação nas duas ONGs de amamentação, e eu acabei virando naturalmente um 'expert', então 'mas não está amamentando? Minha filha tem seis anos e mama no peito', aí os caras 'ah, que absurdo!', parece que é um ET. Falo que Lucas que tem três mama absurdamente, e que minha esposa ainda hoje tem muito leite, e ninguém acredita (Diogo, marido de Virgínia, que não vacinou).

O retorno ao trabalho, porém, foi vivenciado de diversas maneiras pelas mulheres. Duas mães, Jaqueline e Manuela, sentiram alívio e prazer por regressar ao trabalho, vividos como um resgate da liberdade perdida pela maternidade. Apesar delas seguirem a norma médica do aleitamento materno e os cuidados ao lactente durante a licença maternidade, elas vivenciaram esse momento com um peso e sensação de prisão devido à amamentação e mudança na rotina. A maioria, contudo, viveu isso com certa tranquilidade, apesar do cansaço muitas vezes relatado, buscando valorizar os dois projetos, a maternidade e o trabalho, como importantes e complementares na sua biografia. Algumas mães, Clara, Paula, Virgínia e Elaine, porém, viveram a maternidade influenciada pelos preceitos da maternidade ativa, protagonizando e encabeçando os cuidados ao filho de uma maneira supervalorizada no âmbito de suas vidas e assim, colocaram o exercício maternal em primeiro plano em detrimento à carreira profissional. Nessas famílias, predominou-se uma conformação do homem ser o provedor principal ou total, e da mulher se dedicar aos cuidados domésticos e do filho por escolha, reduzindo sua carga horária fora, ou fazendo trabalhos freelances, ou ainda optando por não trabalhar nos primeiros anos de vida do filho.

Então assim, não vou negar para você, os primeiros meses foram bem difíceis para mim. Bem difíceis. Aí eu lembro que na primeira semana que eu fui tirar o ponto o doutor me viu assim, sentada, 'doutor, o senhor me faz essa semana uma laqueadura?', porque aquilo para mim eu não estava dando conta, não dormia, não comia... Aí ele falou 'ah, Jaqueline, logo pensei que você ia baquear, porque você teve uma gravidez super ativa, trabalhou até o último dia' de repente Carolina me via presa o tempo inteiro por causa da questão de amamentação. (...) E aquela 
dependência. Então, quando completou seis meses, que eu voltei a trabalhar, nossa, parece que minha vida mudou (Jaqueline, esposa de Camilo, que vacinou).

Ah, para mim assim, não foi uma experiência tão boa. Eu tiro muitas coisas boas, lógico, pelo fato de estar 24 horas com Gabriel, porém assim, se eu pudesse voltar no tempo eu não faria igual, de jeito nenhum. Eu acho que seis meses é muito tempo, ele ficou super apegado a mim. $\mathrm{Na}$ verdade foram seis meses que mais briguei com o meu marido também, porque essa coisa de dizer que porque eu estou de licença maternidade eu cuido da criança, eu não concordo. E assim também, eu sempre fui muito ativa, fiz muita coisa, então com um recém-nascido, acabava ficando em casa. (...) Eu amamentei o tempo todo, só dei leite materno, mas foi difícil para ele pegar mamadeira, ele ficou super choroso, super manhoso, só ficava grudado em mim. Então eu vejo que essa lei nova de seis meses, e depois você volta, não acho que é interessante. Eu acho que interessante seria os quatro meses e você voltar gradativo. Porque assim, um dia eu tenho 24 horas com ele e no outro dia eu não fico com ele nada. Então às vezes eu vejo que se fosse assim, gradativo, como a gente faz uma adaptação na escola, teria que ser igual, porque foi bem mais ou menos desse jeito. Um dia ele tomava leite no meu peito, eu ficava com ele 24 horas. No outro dia ele parou, porque tive que introduzir a mamadeira, porque passa seis meses, começa a comer comidinha, começa a tomar suco e aí eu volto a trabalhar. Ou seja, são 'n' mudanças para ele em um dia só, em um tempo só. Então para ele foi muito difícil (Manuela, esposa da Nicolas, que selecionou).

Mesmo diante da diversidade, o que chamou a atenção nesses casais, e que os aproximaram simbolicamente, foi o desejo de eles próprios serem os agentes do cuidado ao filho. Para eles, fazia parte do ideário de parentalidade ficar junto e perto do filho o máximo possível, mesmo frente às necessidades do trabalho fora. Conforme seus relatos, eram atribuições dos pais o cuidado direto ao filho como banho, trocar fralda, dar de comer, por para dormir etc. (mesmo para naqueles que tinham babá, empregada doméstica, ajuda das avós ou criança na creche); brincar junto do filho; decidir e escolher o que é melhor para seu filho (por um sinergismo entre o que faz sentido dentro do modo de vida sociocultural do casal e o respeito à singularidade desse indivíduo que está se desenvolvendo); e, por fim, assumir a responsabilidade do filho em todos os 
aspectos de sua vida. Assim, executar projetos que irão compor a biografia do filho, escolher o médico e a via de parto, o pediatra, o tempo de aleitamento materno, os tipos de alimentos, decidir entre a escolinha, babá ou um deles abdicar de seu trabalho fora para ficar com a criança, entre outras decisões e planejamentos do cuidado infantil foram de tal forma introjetados e vividos como ação natural do exercício parental nesses casais.

Esse sentimento de estar junto do filho foi vivido independente do tempo real que os pais e as mães ficaram com as crianças em casa devido seu trabalho fora, ou seja, o que as falas revelam é que se privilegiou foi a qualidade do encontro com o filho. A percepção de onipresença no cuidado filial mesmo diante dos demais afazeres da vida contemporânea fez com que pouco aparecesse nos depoimentos o sentimento de culpa parental. $\mathrm{O}$ que prevaleceu foram falas que valorizaram a conciliação da vida pública e privada e, ao invés da culpa, apareciam relatos de cansaço. As mães que decidiram se afastar do emprego para ficar integralmente em casa (Clara, Paula, Virgínia e Elaine) se destacaram do restante, pela percepção de que para viver a maternidade de forma plena, como elas desejavam e valoravam, era necessário, pelo menos nos primeiros anos da criança, abdicar do trabalho fora.

Esse ideário de parentalidade, centrado na criança e experimentado pelo desejo e prática dos pais de estarem juntos o máximo de tempo possível nos cuidados básicos, nas brincadeiras, no lazer, na educação entre outras facetas da vida dos filhos, é vivido de forma naturalizada, como se esses valores e práticas associados aos cuidado parental fossem natural, a-histórico, essencial do humano. Porém, na perspectiva da história social da infância, esse ideário parental não fazia parte e se distancia sobremaneira da parentalidade exercida outrora, em que a criança assumia um lugar periférico, de apêndice, ou estorvo na família; e cujas práticas de cuidado infantil eram exercidas não pelos pais, mas pelas amas de leite, governanta ou no internato, além da própria existência da roda dos expostos, ou seja, práticas sociais aceitas e naturalizadas anteriormente (Ariés, 1981; Badinter, 1985; Nunes, 2011) e muito distante das introjetadas no ideário de parentalidade na atualidade, reproduzido e valorado por esses casais. Assim, a parentalidade é uma construção sócio histórica com rupturas, permanências e resgates de valores e práticas, que pode ser melhor compreendida por 
meio do aspecto relacional, relação dos pais com os filhos e dos pais entre si frente ao cuidado à criança, de forma contextualizada.

Nesse sentido, a lógica interna dessas famílias de camadas médias e escolarizadas de São Paulo, fundamentada na conformação híbrida entre o planejamento, desejo de controle, construção de projetos para o filho e o ideário de uma parentalidade participante em todas as esferas da vida do filho, vivida de forma internalizada como uma ação natural do exercício parental por esses pais, pode justificar o quanto as decisões em saúde do filho, incluindo a escolha da (não) vacinação, são tomadas e vivenciadas como algo do domínio familiar privado. Todos os casais viveram essa experiência (vacinar, selecionar ou não vacinar os filhos) como uma prática do exercício parental. Nessa lógica, a intenção parental de nortear a construção da singularidade do filho, típica do processo de individualização da sociedade complexa contemporânea (Velho, 1987, 1994) e, ao mesmo tempo, fazer escolhas que transmitem sentido ao modo de vida dessas famílias, faz com que a vacina, uma ferramenta de saúde hegemonicamente prestigiada, seja (des)valorizada conforme ethos individualizante. A vacinação, para esses pais, é um quesito como tantos outros do cuidado infantil (banho, fralda, escola, babá, pediatra, alimentação etc.) e, assim, compreendido como uma escolha frente à pluralidade de possibilidades.

Nesse sentido, para além da dinâmica familiar, serão aprofundados a seguir como se conformaram o cuidado infantil e o exercício parental entre o casal, e sua associação com escolha pela (não) vacinação. Predominaram dois perfis, um relativo aos cuidados infantis em geral, como banho, alimentação, troca de fralda, educação etc., que entra em cena a maior participação do pai nos afazeres domésticos e no trato com o filho; e outro, em contraste, referente aos cuidados em saúde e a escolha pela (não) vacinação, que foi protagonizado majoritariamente pela mulher; e ambos irão repercutir diferentemente, com graus variados de confluências e tensões, nas relações conjugal e geracional dessas famílias.

\subsection{Parentalidade e a nova paternidade: uma questão relacional}

Para a maioria dos homens entrevistados, o cuidado paternal à criança foi 
associado predominantemente ao sentimento de proteção ao filho. No tocante à escolha sobre vacinar ou não a criança, a expressão de sentimento de dever cumprido foi patente, evidenciando uma forte correlação entre o significado de ser pai e proteger o filho, reproduzindo a permanência da tradição do pai provedor e protetor da família (Costa, 1999; Vaitsman, 1994), mesmo na coexistência de outros significados contemporâneos.

O que muda quando você é pai é que você quer proteger mais. Então às vezes algumas coisas que você achava bobeira, bobagem, você acaba tendo uma opinião diferente. Mas eu sempre encarei vacina como algo importante e que deve ser feito (Camilo, esposo de Jaqueline, que vacinou).

Eu acho que sim, pela questão da prevenção, fomos fazer tudo, todos os cuidados, as vacinas todas necessárias para que não tenha, tenha um risco mínimo de pegar doença, e se têm doenças que já estão mapeadas e já tem vacinas, vamos tomar vacina, então é isso. É sempre na prevenção, depois de ser pai você aumenta a importância disso, porque sem ser pai você não pensa muito nisso (Bruno, esposo de Fernanda, que vacinou).

$\mathrm{Na}$ diversidade de vivências conjugais e parentais, alguns aspectos afins aproximaram esses casais no que tange à paternidade. Um deles foi a percepção predominante por eles, e por parte das esposas, de presença e participação nos cuidados básicos do filho e domésticos, fenômeno descrito como "nova paternidade". Essa percepção de presença no cuidado do filho foi independente do tempo gasto no trabalho fora ou com a criança. Mesmo nos casais em que as mulheres acharam que seus parceiros eram pouco presentes, ou que eles podiam ajudar mais, não foi essa percepção que foi passada pelos homens. Essa dissintonia pode ser explicada, em parte, pela possível influência metodológica, como relatado anteriormente na seção 4.3 , em que o encontro entre a pesquisadora mulher com o pesquisado homem ocorreu com certo desconforto. Isso pode ter interferido na qualidade dos depoimentos, aumentando a tendência de mensagens de ordem moral, como "sou bom pai" ou "sou um pai participativo". A atuação paternal nos cuidados do filho dependeu, sobretudo, do teor do trabalho fora, do grau de delegação da mulher no espaço domiciliar e de uma postura ativa deles, por vezes norteada pelo que é cobrado por sua parceira. 
Não sei o que ele [marido] acha, mas eu acho que ele participou pouco com os dois. E aí sabe é cansativo. Acho que eu sou muito controladora também. Então tinha que ser do meu jeito, delego pouco, sei lá. Então acaba ficando, sabe, sobrecarregada (Isabel, esposa de Marcelo, que selecionou).

Eu sempre trabalhei fora, mais tempo, então chegava tarde, saia tarde também, mas chegava mais tarde assim. Eu lembro do Luiz assim que eu queria que a Isabel esperasse para eu chegar para dar banho, porque o que eu mais gostava de fazer era dar banho, e tal. Da Janaína já foi menos, essa questão de ficar esperando, mais prático assim. Mas daí nos fins de semana, sempre que eu podia eu trocava as fraldas, eu sempre gostei de ajudar a cuidar (Marcelo, esposo de Isabel, que selecionou).

O cuidado do filho e doméstico pelo homem era, de um modo geral, acordado entre o casal, em que as negociações levavam em conta tempo, disposição, habilidade etc. Essa negociação era norteada majoritariamente pela mulher, cuja participação do parceiro foi parcialmente influenciada ou condicionada conforme o grau de cobrança e de delegação feminina. Foram frequentes os desabafos de algumas mulheres sentindo-se sobrecarregadas com as atividades do lar, cobrando mais presença de seus companheiros, mas que, ao mesmo tempo, não deram muito espaço para que essa participação masculina se efetivasse. Era como se parte delas assumissem algumas tarefas alegando que eles não fazem bem, não tem a mesma habilidade, o mesmo cuidado ou falta de tempo; e desejassem que esses afazeres fossem realizados pelo homem mas sob sua condicional, não sob algo construído em conjunto ou deixando um espaço de autonomia do pai.

E no começo ele que, a gente tinha combinado que ele que ia dar os banhos, só que ficou difícil para ele dar assim porque... Não sei, o pai demora um pouco mais para pegar o jeito, a pegada na mão, na firmeza, que a gente toda hora está com a criança, está no peito, então você vai tendo ai uma desenvoltura maior. Então até que a gente falou 'não, espera ela ficar um pouquinho maiorzinha para você dar banho e deixa que eu estou mais habilidosa', mas ele sempre foi muito participativo, de trocar fralda, então eu dava mama e ele arrotava, então sempre ele foi muito envolvido, até hoje, de fim de semana ele quem dá banho, então ele me ajuda muito e participa muito assim (Fernanda, esposa de Bruno, que vacinou). 
Eu sou super pentelha na questão da divisão de tarefas assim e o Rafael é muito participativo, então funciona. Agora, seria assim, se eu não fosse pentelha, eu acho que os cuidados se dariam da seguinte maneira: em uma família normal, pelo que eu tenho visto é assim 15, 20\% dos cuidados ele faz, o $80 \%$ da mãe, né. Então, se eu não pentelhasse acho que seria 35\%, bem mais do que a média. Mas eu chego junto e 'não, não, não quero saber, vai você, agora eu tenho que trabalhar, você fica', e ele aceita tudo muito numa boa. Ele estimulado ele vai muito bem assim, divide comigo. Agora, se eu não falar nada, a gente fica naquela situação assim, fraldas para trocar e tal, é um pouco masculino esse não achar que é responsabilidade dele, né. A criança está com uma fralda suja, é óbvio. Então, a gente divide sim, mas de uma maneira, porque eu estimulo bastante assim (Andreia, esposa de Rafael, que selecionou).

Fica evidente nos depoimentos sobre a participação do homem nas atividades domésticas e no cuidado do filho a importância do caráter relacional, majoritariamente o conjugal, nas negociações e no lugar predominante que a paternagem assumiu nestas famílias. Isso já foi encontrado em outros estudos, em que a relação conjugal mais equânime, em maior harmonia e com maior vínculo com a esposa, mostrou-se fundamental para uma maior presença do parceiro na corresponsabilização com o filho, ou seja, para o homem (diferentemente da mulher), o vínculo com a esposa e não o vínculo direto pai-filho foi mais primordial ou determinante para a dimensão do seu exercício de paternidade (Bustamante; Trad, 2005; Quadros, 2006; Falceto et al., 2008).

Permanece em muitos casais o caráter de ajuda à esposa, também encontrado em outros estudos sobre a nova paternidade (Guzmán, 2008). Nesta ajuda, porém, ficou evidenciado certo conflito, em que de um lado há uma cobrança e insatisfação por parte de algumas mulheres sobre as atribuições e presença do homem nas atividades domésticas e, ao mesmo tempo, por outro lado, estas mesmas mulheres não dão muito espaço e delegam pouco, para esta maior participação masculina que cobram e exigem. Parece que esse teor de ajuda acontece por um sinergismo entre o que as mulheres querem compartilhar e dividir, sem perder seu espaço de domínio e poder no doméstico e cuidado com o(s) filho(s), e o que é cômodo e agradam os homens que, por sua vez, não batalham por um espaço maior. 


\subsection{Parentalidade nos cuidados em saúde da criança: um lugar feminino e a permanência do ideário da "boa mãe"}

As questões envolvendo a saúde do filho de um modo geral (escolha e ida ao pediatra, decisão de ir ao pronto socorro ou de ligar para o pediatra em caso de doença aguda, dar ou não medicação ou vacinas, entre outras situações) foram predominantemente abraçadas, assumidas e, por fim, exercidas pelas mulheres, independente do grupo estudado - que vacinou, que selecionou ou que não vacinou o filho. Este cenário foi justificado tanto pelos homens quanto pelas mulheres por uma maior familiaridade feminina sobre temas da área da saúde, um limiar menor masculino em tolerar e lidar com o filho doente, falta de tempo paterno e falta de interesse do homem em alguns assuntos de saúde, em comparação às mulheres. Mesmo os pais que nesse estudo participaram das decisões sobre a escolha do pediatra, sobre medicar ou não o filho doente, e sobre a vacinação infantil, o poder argumentativo e a palavra final que prevaleceu foi da mulher. Houve apenas dois casais que divergiram dessa tendência, Jaqueline e Camilo, que mostraram uma inversão relacional em que ele impôs mais suas decisões em detrimento da opinião da parceira; e Ana e Vinícius, em que as decisões em saúde dos filhos foram partilhadas dentro de uma relação de maior igualdade entre o casal.

Então, ele sempre cuidou do Téo, pegava ele, levava para passear. (...) A coisa de comida a gente divide igualmente aqui. Às vezes o Rafael faz mais até comida do que eu. A limpeza também é muito 50\%, 50\%. (...) A escola do Téo o Rafael é muito presente. Ele que abre a agenda para ver se tem bilhete, ele que pergunta do lanche, se comeu, se não comeu, o que comeu. (...) Pediatra ele não faz questão nenhuma de ir, em nenhum médico. Porque os médicos que a gente vai são papos longos. Então pediatra a gente não divide tão bem assim. Aí eu assumo geral (Andreia, esposa de Rafael, que selecionou).

[Falando sobre os cuidados em saúde do filho] É que eu acho que ele acaba deixando mais. Não falei dele, né. (gargalhada) Então acho que nenhuma talvez, é que eu acho que ele deixa mais na minha mão (Isabel, esposa de Marcelo, que selecionou). 
Então, em relação aos médicos sempre foi a Isabel que decidiu tudo, eu só criticava as vezes que eu achava que alguma coisa era demais, e tal (...) e era mais assim, a Isabel tomava as decisões e eu segurando daqui, dali, pra tentar fazer o mínimo do que eu acho certo (Marcelo, esposo de Isabel, que selecionou).

[Falando sobre os cuidados em saúde do filho] O Fábio fica em pânico e por isso que ele acaba deixando por minha conta, porque ele sabe que ele fica em pânico, que ele não consegue se controlar, ele não consegue entender que a gripe tem um começo, um meio e um fim. Então qualquer coisa ele fala pra mim 'você acha melhor a gente ir pro pronto socorro? Você ligou pro médico?' (...) Então ele fica super tenso, por conta disso até que ele não se mete muito, porque ele fica tão tenso, e ele sabe da tensão dele, que ele fala 'Você que sabe, confio em você'. (...) Como eu que ficava com as crianças eu banquei, mas eu sempre me sinto super pressionada, se não está melhorando, eu sei que ele começa a ficar meio assim comigo, como se a responsabilidade é minha (Elaine, que não vacinou).

Ela gosta desse assunto [vacinação]. É um negócio que ela gosta de ler, de saber, de aprofundar. E eu não tenho o mesmo interesse que ela, o meu é muito mais superficial do que o dela, a minha profundidade nesse assunto (Fernando, esposo de Amanda, que não vacinou).

Mas ela foi me munindo de informações, porque eu trabalho. Eu trabalho em banco, o meu dia a dia é muito corrido, então é meio complicado eu parar para ficar na frente de um computador vendo alguma coisa, ou lendo um livro (Diogo, esposo de Virgínia, que não vacinou).

E acho que vou ter que repensar [sobre a vacina do filho]. Agora que estou com mais tempo livre porque não estou trabalhando formalmente. Eu acho que vou voltar às questões, agora vai ser a minha vez de lidar com isso, mais diretamente. Porque quando a gente tomou essa decisão foi mais a Cláudia, ela que estava com mais tempo livre para fazer isso (Francisco, esposo de Cláudia, que selecionou). 
Essa configuração pode ser explicada sobre dois aspectos. O primeiro deflagra, a despeito da nova paternidade, a expectativa social e preponderantemente aceita de ser a mulher que tem que ajustar sua vida profissional com as intercorrências em saúde dos filhos em comparação com seus parceiros. Nessa desigualdade, o homem passa a ter menos contato com as doenças típicas da infância, conhece menos como seu filho reage, e a insegurança resultante disso gera menor tolerabilidade deles perante essas situações e reforça a perpetuação de delegar as questões de saúde filial para sua mulher. Outro aspecto importante é a naturalização construída sócio historicamente que associa o cuidado em saúde infantil ou de qualquer familiar como um atributo feminino, pelas características de leveza, habilidade e olhar atento, paciência entre outras. Esses atributos foram enaltecidos na emancipação das mulheres pertencentes às camadas de maior renda no início do século XX, permitindo sua entrada no mercado de trabalho em paralelo com o processo de especialização em algumas áreas de atuação e saberes sobre a infância como as da educação, de assistência social, de enfermagem etc. (Nunes, 2011). Essa permanência também foi vista nos estudos da literatura científica sobre cuidado em saúde, que nominam a mulher como a principal responsável pela saúde no interior da família, reforçada tanto pelos pesquisadores - que dão pouco espaço à interlocução com o homem - quanto pelos participantes pesquisados, mulheres e homens (Gutierrez; Minayo, 2010). O maior distanciamento do homem em comparação às mulheres no cuidado em saúde do filho também foi relatado na literatura sobre a nova paternidade, cuja configuração predominante foi uma postura de ajuda à esposa, com a escolha baseada no prazer e no que mais gosta de fazer e, por conseguinte, ter que lidar com uma criança doente não se caracteriza algo gostoso ou prazeroso.

$\mathrm{Na}$ diversidade de maternagem encontrada nesses casais, e mesmo diante da preponderância da coexistência da soberania do protagonismo feminino nos cuidados em saúde e com uma maior participação masculina nos cuidados filiais e domésticos mais gerais, houve uma característica que aproximou o universo da maternidade da maioria dessas mulheres, o ideário da "boa mãe".

Esse ideário de "boa mãe" passa a ser abalado quando algumas mulheres decidem, em conjunto ou não com seus parceiros, romper com algumas normas estabelecidas pela medicina hegemônica, como fazer um parto em casa ou não vacinar o filho. Essas mulheres, majoritariamente as que compartilham preceitos da corrente da 
maternidade ativa, ao buscarem um resgate do protagonismo da mulher no campo do cuidado materno-infantil, usando argumentações de ordem ecológica, naturalista e biologizante, ancoradas numa racionalidade médico científica, sentiram-se ameaçadas do seu posto de boa mãe, socialmente construído. Elas expressaram grande preocupação acerca do não reconhecimento social de que a escolha pela não vacinação dos filhos está inserida num contexto de cuidado parental, pois para elas e para seus maridos, o que ocorreu foi justamente o oposto, a escolha por não vacinar fez parte de uma decisão consciente, pensada e pesquisada, almejando alcançar o melhor para seu filho conforme o modo de vida de sua família.

É desespero de mãe, acontecer alguma coisa e eu ter que provar que sou uma boa mãe. Ou as pessoas vão julgar "você é uma péssima mãe, porque você não vacina. Você não é digna porque você não vacina', como se não tivesse todo assim, como se ser uma boa mãe, um bom pai fosse só isso. Não, eu vou fazer o melhor. E eu acho que o melhor cada um tem a sua consciência (Amanda, esposa de Fernando, que não vacinou)

É uma coisa que tem em relação à maternidade, que qualquer coisa que acontecer com o seu filho, porque você tomou uma decisão de ser diferente da maioria, é porque é culpa sua. Se seu filho tiver difteria, por não ter a vacina, é culpa sua. Então, acho que isso pesa muito sobre a mulher, a gestante, mãe de uma criança pequena. Então, acho que essa coisa da gripe suína tinha a ver com esse universo, se acontecer uma coisa com você e você não ficou em casa trancada, e andou de ônibus e metrô, é culpa sua. É uma coisa que tem mais a ver com uma coisa de imaginação, de sentir essa coisa, que eu digo, sentir que eu sou uma boa mãe, que estou cuidando, segurança etc. (Cláudia, esposa de Francisco, que selecionou).

Fiquei magoada que ele [seu pai, avô da criança] não pudesse entender que essa era a decisão que eu achava que era a melhor decisão para cuidar do meu filho, para que pudesse mantê-lo o mais saudável possível. Por ele entender que era uma decisão irresponsável minha; que achasse isso, que eu era uma irresponsável, que eu não estava entendendo o que estava fazendo com esse atraso [da vacinação do filho] (Sílvia, esposa de Hugo, que selecionou). 
Algumas mães expressaram que as pressões e interferências sociais no exercício maternal são além da questão da escolha da (não) vacinação, e alcançam diversas - se não todas - as dimensões da maternagem. Elas revelaram certo incômodo sobre as normas e julgamentos sobre a infância e o cuidado infantil de forma mais ampla (Nunes, 2011), abalando sua autonomia no cuidado ao filho e suas decisões maternais vividas de forma singularizada, sempre remetendo à ameaça e sombra do ideário de boa mãe.

Eu acho que depois de ser mãe, eu passei a ser mais tolerante com outras posturas de outras mães, porque eu acho que quando você é mãe você escuta tantas coisas, tantas opiniões, tanta gente dando palpite, que eu acho que é uma coisa um pouco chata, você ter uma imposição, então é assim... Então, eu entendo. O Alex [marido] fica revoltado, eu entendo a postura de quem não vacina, para o meu filho eu não vou correr esse risco. Do mesmo jeito que eu entendo o radical oposto, acho um absurdo, fico revoltada, não me conformo, mas também não vou chegar para essa mãe e falar 'olha, você dá muito antibiótico ou você deu todos os reforços', porque eu entendo que talvez na cabeça dela seja o melhor que ela esteja fazendo. Do mesmo jeito que eu ouvi um monte de pitacos em relação ao que eu estava fazendo, se eu estava dando de mama, (...) 'não, mas você está dando só o peito? Você tem que dar chá. Não, você tem que dar comida de tal jeito...'. Você ouve tanta coisa, que chega uma hora que você tem que se proteger um pouco disso, dessas opiniões, então acho que isso me fez ficar mais tolerante em relação às outras pessoas (Beatriz, esposa de Alex, que vacinou).

Eu não falo com ninguém que eu não vacino. Tem, enfim, acho que todo mundo quer cuidar do filho dos outros, todo mundo acha que tem alguma responsabilidade sobre o filho alheio, sofri bastante com o Sling, por exemplo, eu vou no pão de açúcar com o Sling é tranquilo, ninguém fala nada, eu vou no Futurama, nossa! O pessoal fala horrores, agressões, 'sua louca! Não está vendo que a criança está roxa?', daí para baixo (Elaine, que não vacinou).

O ideário da boa mãe e bom pai foi estimulado e alimentado pelo movimento médico higienista e pela puericultura por meio da responsabilização dos pais nos cuidados dos filhos - e sua consequente culpabilização em caso de fracasso. Partindo de argumentações embasadas cientificamente, edificaram-se normas e condutas para as 
funções de maternagem e paternagem "ideais" necessárias para garantir o adequado desenvolvimento da criança: o pai deveria ser provedor da família, e a boa mãe deveria seguir os preceitos do amor materno e da mãe higiênica (Orlandi, 1985; Novaes, 2009; Nunes, 2011).

A vacinação tornou-se, então, um dos pilares das orientações da puericultura e também da pediatria e da saúde pública. Nesse cenário, ser "boa mãe" no Brasil era e continua sendo ter a carteira vacinal do filho completa. A vacinação infantil deixa o lugar de recomendação técnica para o de dever dos pais. Apesar dessas mulheres viverem num contexto diferente do encontrado no final do século XIX e início do XX, nota-se a penetração profunda dessas normas de conduta sobre o cuidado infantil e do mesmo mecanismo coercivo, a culpabilização, no imaginário dessas mulheres, tão cara que persiste até hoje. A permanência de valores associados à imagem da boa mãe pode justificar os medos, culpa e cobranças em torno da reprodução ou ruptura com este papel.

Essas mães expressaram um ideário de maternagem norteado pelo desejo de apropriação plena do cuidado geral e em saúde do filho, de forma singularizada, com liberdade e autonomia; e, ao mesmo tempo, ele está preso à permanência do fantasma da boa mãe, cuja carapaça é assumida ou rejeitada de maneira dinâmica e ambivalente, uma vez que este ideário as protege e as ameaça, simultaneamente. Há, portanto, uma relativização da autonomia e da singularização do cuidado parental que, num primeiro momento, nos depoimentos das mães que selecionaram ou que não vacinaram seus filhos, apareciam como inquestionáveis.

\subsection{A relação conjugal e (não) vacinação infantil: entre a confiança e a corresponsabilização}

No capítulo 6 "A tomada de decisão sobre a (não) vacinação dos filhos", foi mostrado como se configurou a escolha pela (não) vacinação dos filhos, nos diferentes grupos, que vacinaram, selecionaram e que não vacinaram seus filhos. Esse processo, porém, ocorreu no âmbito privado, e uma vez que o desenho metodológico priorizou conformações de famílias nucleares, se supõe que ele foi permeado por negociações, tensões ou conciliações entre os casais. 
Predominaram dois perfis, um de aceitação plena pelos casais que vacinaram seus filhos, e outro questionador, em diferentes graus, pelos casais que não vacinaram e que selecionaram as vacinas. O primeiro nem chegou a se configurar como uma "negociação" conjugal, pela forma consensual e sem conflitos da escolha, já que a vacinação infantil para ambos não era uma questão a ser debatida e sim uma prática a ser perpetuada. O segundo, por sua vez, evidenciou que a problematização da via de parto e posteriormente da vacinação infantil foi desempenhada majoritariamente pelas mulheres, cuja disparidade dos papéis revelou tensão e conciliação no âmbito conjugal desses casais, que serão aprofundadas a seguir.

O protagonismo feminino na escolha por não vacinar ou postergar a vacinação dos filhos se fortaleceu diante do sentimento de confiança do homem em sua mulher. A justificativa da confiança foi preponderante em detrimento à decisão individual do homem sobre o assunto, a favor ou contra.

A gente acabou achando melhor não dar [as vacinas]. E Amanda me influenciou bastante nisso aí. (...) Mas eu tenho muita confiança nela, então, eu tenho certeza que ela não orientaria nada de mal para Mariana também. Então, a gente leu bastante coisa de pesquisa, de internet, um outro trabalho científico a respeito. Fiquei bem tranquilo também. Achei que era melhor não vacinar, pelo menos naquele momento (Fernando, esposo de Amanda, que não vacinou).

$\mathrm{Na}$ hora que Clara falou 'não, a gente não vai vacinar as nossas filhas', 'como assim?', foi aí que começou, alguma coisa me chamou a atenção, falei 'como não vacinar? Não, que coisa louca isso?' De repente ela começou a falar, 'não vamos vacinar'; 'não, não vamos, também acho que não vamos, acho que não tem nada a ver', e foi uma decisão conjunta, mas foi a Clara que... Não foi ela que fez a minha cabeça, foram as informações que chegaram até a mim que mudaram a minha cabeça. A Clara só deu o pontapé, entendeu (Jonas, esposo de Clara, que não vacinou).

Eu tomei a minha decisão e estava tranquila com a minha decisão. Aí ele [marido] 'Tá, eu confio em você, você pesou, está legal'. Eu mando estudos para ele, ele dá uma lida, tenho certeza que ele não lê. 'Ah, entendi por que você tomou essa 
decisão, faz sentido, beleza'. (Andreia, esposa de Rafael, que selecionou).

Isso ficou evidente em falas de dois pais que não vacinaram, que revelaram que se tivessem casado com outra mulher, eles com certeza teriam vacinado seus filhos como a maioria das pessoas.

Se eu não tivesse casado com Andreia, e tivesse casado com uma outra pessoa, que não tivesse muito interesse, meu filho tomaria todas as vacinas, as do Delboni, essas todas que existem, que custam sei lá quanto? 500, 600 reais, nem sei o preço, 200, né? Mas isso eu devo totalmente a Andreia (Rafael, esposo de Andreia, que selecionou).

Em contrapartida à preponderância de uma postura masculina mais frouxa ou incipiente, a qual se predomina a ação de acatar a decisão da mulher justificada pelo argumento da confiança na parceira, a negociação desigual foi minimizada por alguns participantes de ambos os sexos, que reiteraram um lugar masculino nesse processo, e que esta não foi de coadjuvante.

Na verdade eu confio muito na Paula, demais, então... Não que eu feche meus olhos para tudo que ela fala em relação a isso, mas, da mesma forma como eu a escolhi para ser mãe, forma bem machista de dizer né, para mãe dos meus filhos, se eu a escolhi eu tenho que estar do lado dela nas decisões. Não que eu tenha que aceitar tudo, mas é mais por confiança mesmo (André, esposo de Paula, que não vacinou).

No começo eu acho que ele deve ter me achado uma louca, mas como ele sabe que quando eu gosto de um assunto eu vou ao fundo, ele confia muito no tanto que eu estudo, de uma certa maneira. Porque ele sabe que 'ah, resolvi não dar vacina'; ele sabe que se eu fiz isso é porque realmente tenho motivos fortes, mesmo que ele não se preocupe em ler tudo que eu leio, entendeu, ele confia no que eu estou entregando. Não é uma coisa que eu fale e ele segue (Virgínia, esposa de Diogo, que não vacinou).

Eu sinto que essa pesquisa partiu um pouco mais de mim assim. De dizer, ele está um pouco, eu sinto isso, um pouco mais é concordando. Não é exatamente uma postura passiva de 'o que 
você decidir está decidido' mas é uma coisa de 'o que você está pensando sobre isso?' e de concordar plenamente, ser uma decisão totalmente conjunta a prorrogação da vacinação. Também ser uma decisão conjunta que iria para a escola então que tinha que vacinar. Mas essa coisa de qual vai dar, no posto e tal, de levar, fui eu que fiz (Cláudia, esposa de Francisco, que selecionou).

Apesar desse processo majoritário expressado com poucas tensões ou negociações diante a uma desigualdade de gênero; alguns casais, porém, revelaram conflitos e evidências de negociações no que diz respeito a (não) vacinação do filho. $O$ casal Ana e Vinícius se diferenciou por uma relação conjugal de maior igualdade no âmbito privado, em que todas as decisões, desde a escolha do parto, até os cuidados básicos e em saúde das filhas, incluindo a vacinação, foram ativa e igualmente discutidas e debatidas entre os dois. Outro casal, Sílvia e Hugo, se destacou dos demais pois foi o único em que a problematização da vacina partiu de ambos, ela por ter um irmão autista e ele por ter uma mãe americana homeopata não-vacinadora. O destaque aumentou ainda mais pois, diferente de todos os demais casais, foi o Hugo que não queria vacinar o filho e a Sílvia que quis dar certas vacinas, pelo medo do filho pegar alguma doença ao entrar na escola. O último casal destoante foi Elaine e Fábio, em que a questão da não vacinação era a principal divergência conjugal, a ponto dela colocar como condicionante de sua participação a exclusão do parceiro no estudo. Essa tensão ficou mais gritante, na percepção de Elaine, pelo fato do Fábio ser advogado e sentir que está infringindo uma lei brasileira, para além de sua opinião a favor de vacinar os filhos. Apesar das discordâncias perante a escolha de vacinar ou não a criança e da postura presente e mais ativa do homem em comparação aos outros casais, nos dois últimos exemplos, prevaleceu a posição e escolha da mulher, reforçando a liderança feminina na voz de comando sobre assuntos referentes à saúde do filho.

[Sobre o parto em casa] No final das contas assim, eu sempre fui mais cético, então a gente tinha discussões duras, negociações duras, entendeu, porque ela queria, estava interessada, e eu 'tudo bem, vamos ver se é verdadeiro', e ficava combatendo uma série de coisas como, por exemplo, a visão de algumas dessas mães que 'ah, não tem perigo, é maravilhoso' e tudo mais.

(...)

[Sobre a vacinação] Que na verdade, adiar ou adiar um pouco, é 
relativamente tranquilo de fazer. Agora, decidir vacina a vacina, qual vai ser ou não, o que seria a solução definitiva, isso é muito difícil. Isso é muito difícil, que é o que a gente ainda não tem. A gente negocia muito, a gente discute muito, entendeu? E são sempre negociações duras, duras realmente. A gente briga sobre os assuntos, depois para de falar sobre aquilo, depois volta, são duras sempre. E existe uma tendência a minha posição, eu tentar buscar o equilíbrio na decisão e afastar um pouco, não sei se o estereotipo de emoção e razão, acho que não assim. Acho que em geral sou mais cético, a verdade é essa. Em geral sou mais cético (Vinícius, esposo de Ana, que não vacinou).

Essas coisas a gente não conversa muito porque, enfim... A gente viveu, foi muito ruim para os dois, e acho que para ele [marido] foi muito... Depois da segunda vacinação 'a gente não deveria ter vindo, você sabe disso, né?', e eu sabia. Eu sei que foi mais uma pressão minha do que dele, eu sei que para ele, se eu quiser vacinar, possivelmente vou conseguir convencê-lo de que sim, mas ele também não gostaria de vacinar, que se arrepende de ter feito as vacinas (Sílvia, esposa de Hugo, que selecionou).

Ele queria que eu levasse os meninos naquela semana pra eles tomarem todas as vacinas, porque senão ele ia no sábado, ele ia pôr os dois no carro e dar todas as vacinas. Ai eu falei 'você é louco, você vai matar seus filhos, como assim'. Deu uma surtada, nós brigamos feio, e ele não tocou mais no assunto, enfim, não sei como está isso na cabeça dele no momento. (...) Ele não tem uma opinião formada, não sei te dizer, como em outros assuntos, nós não conseguimos ainda nos acertar, eu até falei que se ele quisesse algumas vacinas, como essa da meningite, a gente poderia negociar algumas que fizessem sentido, porque realmente eu acho que a Sabin não faz sentido nenhum, e ele a princípio concordou, mas depois ele não concordou, por causa dessa nóia de todo mundo toma tudo e você não vai tomar tudo. E até hoje ele não foi pesquisar, não teve isso então. (...) Por isso que eu bato de frente com ele, porque não é uma questão de saúde, é uma questão que desvia disto. Eu estou olhando, pensando na saúde, pensando no bem estar do corpo, e ele está pensando na lei, se alguém denuncia a 
gente, no processo, então o pensamento dele é bem voltado pra isso (Elaine, que não vacinou).

Além dessas tensões mais explícitas, uma mais sutil foi revelada por Vinícius, que viu nos movimentos do parto humanizado e da maternidade ativa uma possibilidade de disputa de gênero. Esses movimentos enaltecem o empoderamento da mulher por meio do resgate do biológico e do natural, e assim, como a maioria dos processos ocorrem no corpo feminino, a função do homem muitas vezes não foi citada ou valorizada. Por mais que se pressupõe a presença do homem em todo o percurso, ela assumiu mais um lugar de apoio e ajuda. Não se fala de parentalidade ativa, de um resgate do cuidado parental aos filhos apropriado pela biomedicina, mas sim maternidade ativa, reafirmando que trata-se de um locus feminino.

Porque tem uma coisa nesse movimento que é o fato das mães estarem readquirindo um certo poder, que eu acho fundamental, acho ótimo isso. Mas tem também uma coisa exacerbada assim, da volta do culto da grande mãe e o, assim, um acirramento da disputa entre homens e mulheres, porque elas veem o médico. Elas não falam das médicas, elas falam do médico. É masculino e quase sempre no singular, é como se fosse um médico mítico. O homem, entendeu, o cientista. (...) Acho ótimo as mulheres adquirirem esse poder, como a Ana, é um poder enorme ela ter conseguido [fazer parto natural em casa]. Todo mundo dizia que ela não ia conseguir, entendeu, ela fez, ela conseguiu, ela tem uma segurança nisso que é enorme, é fundamental. Mas quando começa esse negócio do culto da grande deusa isso me incomoda enormemente. E não é porque eu sou homem, é que eu acho que isso é um viés, atrapalha a decisão objetiva (Vinícius, esposo de Ana, que não vacinou).

O contexto de produção dos dados empíricos pode ter favorecido a expressão de tranquilidade nas negociações conjugais frente às decisões em saúde e na vacinação do filho, exceto nesses três casais relatados. Esse "silêncio" ou pouca tensão pode ter influência metodológica, primeiro pela pesquisadora ser mulher, e por isso, alguns homens entrevistados podem ter sentido desconforto em revelar possíveis tensões e posições contrárias às de suas mulheres; e segundo, tanto os homens quanto as mulheres podem ter veiculado falas que acentuam alguns ideários e valores morais da família conjugal, que tendem a reforçar a sintonia conjugal e a ideia que as decisões familiares 
são acordadas pelo casal, sobretudo pelo fato de saberem que as entrevistas eram com ambos.

Tirando o viés do método, mas ciente de que se o entrevistador fosse homem poderia ter alcançado outras dimensões que não apareceram nos dados empíricos, a pouca expressividade das tensões conjugais, sobretudo no que diz respeito à escolha de não vacinação do filho; e a prevalência nos casais entrevistados de uma dinâmica conjugal composta pela soberania do protagonismo feminino no tocante à saúde do filho e pelo consentimento e adesão masculinos, por meio da relação de confiança, pode ser expressão do princípio de reciprocidade das relações de gênero.

Entendida aqui como parte da dimensão relacional de gênero, a lógica da reciprocidade foi estudada e utilizada como noção-chave na análise da divisão sexual de papéis dentro da família, muito presente em estudos de famílias de baixa renda (Sarti, 1989; Fonseca, 1992). Referindo-se à reciprocidade, Sarti enfatiza que "esta lógica organiza e dá sentido às relações de gênero e à divisão de espaços masculinos e femininos no mundo social. Isso quer dizer que cada lado tem uma parte a desempenhar. O desempenho recíproco é o que dá sentido às relações de gênero, tal como são estruturadas" (1989: 39).

Nesse sentido, os dados empíricos desse estudo - que apontaram que as mulheres assumiram mais as funções que cercam as decisões em saúde do filho e que os homens estiveram mais presentes nos cuidados domésticos e filiais em geral - podem assinalar códigos de reciprocidade desses casais, e explicar a tolerância e pouca reivindicação masculina no protagonismo envolvendo o âmbito da vacinação do filho. Os depoimentos dos participantes deflagaram que as mulheres pouco delegaram ou deram espaço para os homens co-assumirem as decisões em saúde filial e, ao mesmo tempo, os homens aparentaram confortáveis com este "distanciamento", sendo algo que foi pouco posto em conflito e justificado pela falta de tempo e confiança em sua parceira, articulação esta que pode ser entendida como uma conformação em sintonia e respeito ao código de reciprocidade.

O domínio feminino das decisões do privado se intensificou nas famílias em que as mulheres decidiram abdicar total ou parcialmente da vida profissional para se dedicar plenamente aos filhos, e por conseguinte, diferente das outras famílias, a renda familiar era quase ou exclusivamente oriunda do trabalho do homem. Nessas famílias, a lógica 
da reciprocidade resgata os papéis tradicionais da família conjugal moderna, do homem ser o provedor e da mulher ser a cuidadora de lar e dos filhos, porém, convivendo com novos valores, como a premissa de "igualdade" das famílias de camadas médias urbanas (Figueira, 1987; Velho, 1987, 1994) e a nova paternidade (Quadros, 2006).

Avançando na discussão, algumas mulheres confessaram que incluíram seus parceiros nas discussões sobre vacinação e saúde do filho, menos para saber a real opinião deles sobre o assunto e chegarem num consenso em conjunto, e mais para dividir com eles a responsabilidade. Mesmo diante da decisão de não dar ou postergar a vacinação do filho previamente estabelecida, algumas mulheres sentiram a necessidade de um apoio do parceiro, e assim, partilharam o assunto para dividir a responsabilização, um compartir para corresponsabilizar.

André: Quando ela me falou eu não sabia das pessoas que recusavam a tomar vacina, não tinha esse conhecimento nem nada. E comecei a ler um pouquinho com ela, e ela me explica algumas coisas. E para mim não tem problema em aceitar a decisão que praticamente foi dela.

Paula: Não, a decisão não é que foi minha, mas é que eu estava em casa de licença maternidade, para mim era muito mais fácil ler, perguntar, ficar no e-mail trocando mensagens e tudo mais. Mas eu passo para ele, eu quero a opinião dele. Ele é o pai, precisa opinar também (André e Paula, que não vacinaram).

Mas eu falei para ele, 'você tem que se informar também, porque depois, qualquer coisa não quero assumir sozinha a responsabilidade, né', você quer meio que dividir, mas ele apoiou bastante (Clara, esposa de Jonas, que não vacinou).

Porque ele não está tão envolvido nas minhas pesquisas, nas minhas leituras, ele se sente inseguro, ele não tem onde se apoiar, ele pensa 'essa louca surtada vai pôr o nosso filho em risco'. Mas até agora ninguém ficou doente aqui, fortemente. Então, ele ainda está no meu apoio e tal. Não sei até que ponto ele me culparia se alguma coisa acontecesse, porque ele está concordando comigo, né (Andreia, esposa de Rafael, que selecionou). 
Quando a gente falou de dar da catapora ou não... Mas é que quando vou falar com ele acho que eu já decidi um pouco, só estou precisando de um apoio, sabe, aí eu decidi, aí eu vou falar um pouco, mas daí preciso só de um apoio (Isabel, esposa de Marcelo, que selecionou).

A maior presença da mulher nos cuidados domésticos e da família, principalmente no cuidado em saúde do filho incluindo a (não) vacinação, releva a permanência das relações de poder entre gêneros mas que, diferente da que prevaleceu nas famílias conjugais modernas (Figueira, 1987; Singly, 2010), agora assume novas conformações, sobre a influência de processos mais amplos sociais, como a individualização da sociedade contemporânea (Beck, 2010), que propiciou a passagem "do indivíduo menos sujeito a autoridades exteriores, mas compensando pelo aumento de uma regulação pessoal" (Singly, 2010: 62).

$\mathrm{Na}$ ótica individualizante, percebe-se nesses casais regulações no interior da família, cambiantes e por vezes contrastantes, expressadas, de um lado, por uma exigência da maioria das mulheres entrevistadas para maior participação dos seus parceiros nas decisões e afazeres domésticos que, contudo, se configurou mais como uma necessidade de dividir as tarefas do lar pelo cansaço da jornada dupla lar-trabalho fora e/ou uma necessidade de apoio. Essas exigências, porém, foram batalhadas pelas mulheres participantes até o ponto em que não elas coloquem em risco seu lugar de poder de decisão e escolha no ambiente privado. Elas reivindicaram uma igualdade sem, no entanto, quererem ceder, compartilhar e desapropriar-se da voz de mando no interior do doméstico, perpetuando a desigualdade de gênero. Em outras palavras, a maioria das mulheres compartilhou não as ações e decisões, mas as responsabilidades da decisão que foi majoritariamente delas.

Diante da perspectiva relacional, do outro lado, sobressaiu uma postura de pouco conflito e pouca reivindicação por mais espaço nesse domínio pela maioria dos homens, cuja ação mais marcante foi a confiança na esposa. Beck (2010: 157), referindo-se aos homens na relação conjugal familiar, "com certa esperteza, insiste-se sobre as velhas atribuições, mesmo que a linguagem tenha tornado-se mais lábil. Defender sua própria imunidade em relação ao trabalho doméstico e aceitar os direitos iguais da mulher não lhes parece contraditório." A premissa de igualdade de gênero é, assim, permeada por contradições (Beck, 2010). 
Diante disso, o empoderamento delegado à mulher no espaço privado pelo movimento médico-higienista e pela puericultura, bancado e valorizado pelas mulheres das camadas mais favorecidas das sociedades urbanas, subordinado-se a um conjunto de normas sobre o cuidado infantil (Novaes, 2009; Nunes, 2011; Freire, 2009) no século XIX e início do século XX, se reconstrói atualmente, na coexistência de relações conjugais com premissas de maior igualdade e na presença sem precedentes na história do homem nos cuidados domésticos e filiais; com a permanência de valores do ideário da boa mãe e na preponderância da mulher nas decisões em saúde do filho.

O empoderamento feminino na contemporaneidade e nesse segmento social assume nova conformação, tanto para as mulheres desse estudo que se identificaram com as ideias da maternidade ativa, quanto para aquelas que não compartilharam ou desconheceram seus pressupostos. A intensificação do processo de individualização da sociedade (e da família) contemporânea permite, diante da pluralidade de possibilidades e escolhas (Velho, 1987, 1994; Singly, 2010), o trânsito dessas mulheres e desses homens, num dinamismo relacional entre avanços e recuadas (Scott JW, 1995, 2005). Como observou Singly, "o trabalho doméstico continua a ser assegurado principalmente pela mulher, mas com uma condição nova: que o homem não tenha a pretensão de controlar o mundo comum", ou seja, para as mulheres atuais "a contrapartida reside no facto de poderem definir, em parte, o mundo comum" (2010: 130).

Beck (2010) salienta que essas (trans)formações no interior da família não podem ser reduzidas ao nível privado, pois sofrem influência do peso do processo de individualização contemporâneo, que atingiu diferentemente os sujeitos conforme o gênero. "Eu sou eu, e em seguida: sou mulher. Eu sou eu, e em seguida: sou homem. Há mundos nessa distância entre o eu e a mulher exigida, e o eu e o homem exigido" sócio historicamente (Beck, 2010: 162; grifo meu) ${ }^{22}$. Para o autor, as contradições entre a autonomia, liberdade, igualdade e as antigas atribuições de gênero na sociedade contemporânea individualizada recaem de forma mais intensa e conflituosa para as mulheres do que para os homens.

Apesar dessa desigualdade, os dados do estudo apontaram que o resquício

\footnotetext{
${ }^{22}$ A tradução dessa frase de Beck (1986) apud Singly (2010) foi muito diferente, por isso vale a pena ser citada, para comparação: "Еи sои еи e depois: eи sou mulher. Еи sou eи e depois: eи sou homem. A distância entre o 'eu' e a identidade feminina imposta, entre este 'eu' e a identidade masculina imposta é um abismo." (Singly, 2010: 132; grifos do autor).
} 
higienista do ideário da "boa mãe" e a valorização da individualidade, trouxeram tanto vantagens quanto desvantagens às mulheres e aos homens, que vão remodelar os códigos de reciprocidade e determinar perpetuações ou abandonos de valores e práticas na intimidade doméstica. Assim, o caminho possível encontrado pela maioria das mulheres participantes que bancaram decisões contra hegemônicas como a não vacinação do filho, num processo de regulação interna individualizante, foi a transferência da culpabilização, que recaia socialmente apenas para ela, para a de corresponsabilização com seu parceiro, mesmo que no caso da não vacinação, isso ocorra ainda de forma incipiente ou frágil.

\subsection{As relações entre as gerações e a (não) vacinação infantil}

As tensões e confluências no interior da família no tocante às relações de geração divergiram nitidamente conforme a tomada de decisão em vacinar ou não os filhos. Para os casais que vacinaram não houve descrição de conflitos entre as gerações, ao contrário, foi reforçada a importância do apoio dos pais ou sogros no exercício parental e explicitado que seguiram a linha da família, não apenas em relação à vacinação, mas nos outros aspectos e valores do cuidado infantil.

Não sei também se é porque as famílias têm isso como muito, eu acho que o vacinar e o cuidado que você tem, médico, tem uma influência muito grande da família, e sempre foi muito automático (Helena, esposa de Guilherme, que vacinou).

Os casais que não vacinaram e alguns que selecionaram, em contrapartida, revelaram uma influência mais tênue da geração de seus pais. Em graus variados, as decisões de ter um parto em casa e não vacinar a criança culminaram num choque de valores e opiniões geracionais. Esta divergência foi justificada pela diferença epidemiológica das doenças imunopreviníveis na ocasião em que seus pais estavam com filhos pequenos em comparação com a situação atual, vivida como de controle; e pela diferença de informação nas duas épocas, como se antes a ausência de informação ou a ignorância no assunto eram fatores que levaram seus pais a vacinarem e agora, com acesso a esses dados, com a intensidade de informações, estes pais atuais acreditam que têm a possibilidade de escolher vacinar ou não seus filhos de forma consciente. 
[Falando sobre a reação de seus pais sobre a não vacinação do neto] É, não foi uma coisa óbvia, não veio deles, demandou um pouco de explicação. Mas minha mãe é muito assim, ela confia muito. 'Agora é a sua vez de errar', essa frase é maravilhosa, 'Sua vez de errar, se vai errar, vai errar. Então é melhor você errar com o seu erro do que com o que eu falar de errado para você, que aí eu vou ter errado. Sua vez de errar, eu já errei muito' (Cláudia, esposa de Francisco, que selecionou).

E aí a questão das vacinas meu pai insistia muito. Ele está agora com 71 anos e tem uma visão bem cartesiana das coisas, ele é espírita, e acredita na medicina, em todas as coisas. Então ele insistiu muito, insistia muito que a gente desse remédio, ficava pressionando. E na questão das vacinas ele foi muito duro com relação a isso. Estava trazendo o tempo inteiro para a gente a questão do Ministério Público, que poderiam tirar a guarda do Antônio, assim, muito forte (Sílvia, esposa de Hugo, que selecionou).

Então, a minha mãe sempre ficou muito preocupada, porque ela via gente morrer. Que ela morava na zona rural, ela via gente morrer de varíola, de sarampo, de rubéola, de paralisia infantil. Então, a minha mãe ficou meio assim 'Como você não vai vacinar! Na minha época não tinha vacina, via gente morrendo!' Aí eu expliquei para ela, ela ficou meio assim, mas ela ficou meio com medo. (...) A minha família eu também não dou muita vez para eles falarem também. Prefiro não, quando alguém começa a encher muito saco, eu falo 'a filha é minha, quem cuida sou eu'. E saio de perto, porque se der papo vai longe o negócio (Amanda, esposa de Fernando, que não vacinou).

Eu acho que a vacina é importante, mas acho que na verdade depois que eu fui mãe mesmo, aprendi muito mais. Porque coisas que eu tenho certeza que minha mãe nem sabe. Minha mãe dava vacina porque estava lá para dar e dava. Hoje na verdade eu sei quando vou dar e quando não vou dar. Entendeu, acho que a gente acaba procurando saber mais (Manuela, esposa de Nicolas, que selecionou).

A minha mãe era uma pessoa muito ignorante nesse sentido, 
entendeu. Meu pai também, sempre trabalhou muito, a minha mãe também. Então, assim, eu acredito que eu tomei todas as vacinas, porque quando era criança eu tomava todas as vacinas (Rafael, esposo de Andreia, que selecionou).

Eu fui criado de uma forma muito diferente da forma que eu crio os meus filhos hoje. Estou com 35 anos, então 35 anos atrás, não se tinha tanta informação como se tem hoje, tantos meios de informação, internet, esse tipo de coisa. Então alguém para saber alguma coisa tinha que ler muito livro. E meus pais sempre trabalharam. (...) Eu vejo a comparação porque morava no interior, que não tinha tanta instrução (Diogo, esposo da Virgínia, que não vacinou).

Em dois casais que selecionaram as vacinas do filho (Manuela e Nicolas, Sílvia e Hugo), ocorreu uma inversão deste conflito, em que as respectivas avós paternas eram contra a vacinação (por serem adeptas da homeopatia) e questionaram seus filhos e noras por terem dado algumas vacinas.

E ela [a sogra] sempre comenta 'ah, não, para que vai dar vacina, coitadinho, sofre tanto...' (...) Então ela ainda tem esse pensamento. E eu sempre falo para ela 'não, Vilma, tem que dar' (...) Ela acredita que mais judia do que previne (Manuela).

Elaine relatou um conflito geracional mais amplo, típico da maternagem da década de 1980 (em comparação com a atual), por estar muito presa a normatizações acerca do cuidado da criança, principalmente pela pediatria, uma divergência para além da temática da vacinação, que culminou na mudança no seu exercício maternal entre o primeiro e o segundo filho.

Então do Leonardo ainda nós não tínhamos experiência, eu ainda tinha uma influência enorme da minha mãe, tinha que dar banho na banheira, então eu tinha todos aqueles apetrechos do bebê de classe média, a banheira que todo mundo tem, um monte de roupinhas, macacãozinhos uns mais bonitinhos que o outro, eu não tinha muita noção. Eu não fui bacana com o Leonardo quando ele nasceu, eu dava altos banhos nele, trocava muita fralda, ele tinha muita cólica, e cada xixi ou cada cocô, eu trocava cada fralda, umas 15 fraldas por dia, eu era completamente sem noção, colocava milhões de roupinhas. Eu descobri que quando eu deixava o pezinho dele de fora, ele parava de berrar um pouco, ele devia berrar de calor, ele devia 
estar desesperado, e com todas essas coisas de não pode sair, banho de sol tinha que ser nove da manhã. Então ainda eu era muito presa a todas essas coisas, que na verdade e não sabia uma alternativa, eu não sabia que não fazia sentido pro tipo de vida que eu tinha, não se encaixava. Eu me sentia um peixe fora d'água, eu fazia as coisas que as outras pessoas faziam, mas ao mesmo tempo eu via aquilo e pensava 'não é possível, tem alguma coisa errada', não conseguia entender. E fui entendendo com o tempo e minha mãe falava 'imagina, não deixa a fralda suja, porque vai assar, passa hipoglós', sabe umas pirações múltiplas, que é muito da geração dos anos 80 , eu nasci nos anos oitenta, e minha mãe é muito dessa geração, de dar todas as vacinas, todos os remédios, encher de roupas (Elaine, que não vacinou).

A mudança epidemiológica das doenças imunopreveníveis por vacina e a possibilidade de acesso a informações, de forma livre e aberta (sobretudo por sites na internet e trocas em redes sociais), foram descritos pelos participantes como os principais responsáveis acerca da construção de olhares diferentes para um mesmo fato/objeto.

As faixas etárias dos participantes revelam que eles nasceram entre os anos 1970 a 1987. Neste período, em 1973 foi instituído o PNI; em 1977 foram definidas as vacinas obrigatórias para crianças menores de um ano de idade (Portaria do Ministério da Saúde $n^{\circ}$ 452/1977) e foi aprovado o modelo de caderneta de vacinação (Portaria do Ministério da Saúde no 85, de 4/4/1977); em 1979 a OMS certifica a erradicação global da varíola; em 1980 foram iniciados os dias de Campanhas Nacionais de Vacinação Anti-Poliomielite; e em 1989 foi registrado o último caso de poliomielite no Brasil (Brasil, 2003; Temporão, 2003; Pinto, 2004; Domingues; Teixeira, 2013). Frente a esse panorama, a vacinação infantil nas décadas de 1970/80 se transformou em uma medida de grande valor, apelo populacional, sinônimo de saúde e proteção às crianças, o que culminou na emergência do que Hochman (2011) chamou de "cultura de imunização" no Brasil contemporâneo. O controle das doenças preveníveis por vacina, por meio do sucesso do programa e das campanhas de vacinação no país, gerou o paradoxo epidemiológico já descrito, a maior visibilidade dos efeitos adversos das vacinas, que corroborou para surgimento e crescimento dos movimentos anti-vacinação atuais (Bedford; Elliman, 2000). A vacina, assim, é vítima de seu próprio sucesso (Paul Offit) 
23.

Foi com o tempo e a massificação da imunização que alguns efeitos adversos foram observados e documentados, como no caso da vacina contra a febre amarela. Os primeiros casos da Doença Viscerotrópica Aguda (DVA), doença rara e potencialmente fatal após a primo vacinação contra a febre amarela, foram descritos na literatura científica no Brasil, França e nos EUA apenas em 2001 (Brasil, 2008). Além disso, em 2009, no Rio Grande do Sul, a partir de dois recém-nascidos com quadro de encefalite, foi relatada a passagem do vírus vacinal contra a febre amarela através do leite materno (CDC, 2010). Esses casos exemplificam como conhecimentos novos sobre os efeitos adversos das vacinas vão sendo agregados com o passar do tempo.

Os casais não vacinadores, portanto, vivem um híbrido de uma situação epidemiológica atual favorável (com as doenças infantis controladas, exceto surtos isolados esporádicos) e a evidência de efeitos indesejáveis pós-vacina, e assim, a vacinação infantil assume, para alguns, outro significado e importância, diferente das gerações anteriores. O que chama a atenção é que além da diferença epidemiológica das duas épocas, que irá conformar valores diferentes sobre a vacinação infantil, o passar do tempo não só controlou as doenças imunopreveníveis, mas também eliminou sua memória (Paul Offit) ${ }^{24}$. O sarampo, por exemplo, que era visto como uma doença potencialmente grave, é ressignificado como uma doença benigna por alguns pais atuais, como descrito na seção 7.1 “As justificativas pela não vacinação", evidenciando um apagamento da memória.

Ademais, os meios de comunicação possibilitaram a qualquer pessoa acessar conteúdos que antes eram mais restritos às pessoas da área de saúde. Normas de saúde, informes técnicos do Ministério da Saúde, da OMS, artigos sobre vacinação entre outros estão disponíveis on line. Assim, a individualização, a busca por singularização da família, a situação epidemiológica e o acesso à informação contribuíram para a mudança de valores e práticas sobre vacinação infantil de alguns pais em relação às gerações anteriores.

${ }^{23}$ Paul Offit é chefe da Divisão de Doenças Infecciosas do Children's Hospital of Philadelphia, e Professor de pediatria na University os Pennsylvania Scholl of Medicine. A mensagem que a vacina é vítima de seu próprio sucesso, assim como a perda da memória da vacinação pelas gerações foi transmitida por Paul Offit em 14 de abril de 2014, no programa Milênio da GloboNews, "Paul Offit fala sobre mito e realidade na medicina alternativa". Disponível em: <http://globotv.globo.com/globonews/milenio/v/paul-offit-fala-sobre-mito-e-realidade-na-medicina-alternativa/3281743/> ${ }^{24}$ Idem. 
Para concluir, o cuidado em saúde e a escolha pela (não) vacinação serviram de objetos para se pensar divergências e convergências das relações de gênero e geração no contexto familiar, e paralelamente, o mesmo ocorreu com o oposto, em que transformações da sociedade mais ampla e da família na contemporaneidade podem ajudar a compreender de forma mais profunda a aceitabilidade da vacinação, assim como outras mudanças no cuidado em saúde infantil. 


\section{A VACINAÇÃO INFANTIL: A RELAÇÃO INDIVÍDUO-COLETIVO}

Esse capítulo visa refletir os sentidos da vacinação infantil, no tocante à relação individual e coletiva, para os participantes. A vacinação é uma ferramenta preventiva dada para o indivíduo, para sua proteção individual, mas ela tem também outra função, a imunidade coletiva, uma proteção da comunidade por meio da chamada imunidade de rebanho, em que indivíduos imunes vacinados protegem indiretamente também os nãovacinados, qualidade esta de grande interesse e importância para a Saúde Pública. Diante dessa característica peculiar das vacinas, é possível, ao atingir uma meta de cobertura vacinal estipulada estatisticamente, controlar diversas doenças imunopreveníveis e inclusive ter erradicado a varíola (Plotkin et al., 2008). A imunidade de rebanho também assumiu relevância na proteção de segmentos específicos da sociedade, que podem se proteger pela imunidade indireta dos vacinados como: prematuros, imunocomprometidos, gestantes, outras situações de contraindicação temporária ou absoluta, indivíduos que tomaram a vacina mas não responderam imunologicamente, falta de acesso, entre outros (Plotkin et al., 2008).

Além dessa marca individual-coletiva das vacinas, os próprios participantes, seres ao mesmo tempo singulares e sociais, deram diferentes sentidos a esse objeto, como mostrado nos capítulos anteriores; e percorreram caminhos diversos para o manejo e sustento de suas escolhas, frente às normatizações médicas, de saúde pública e legais, que culminam nas recomendações do calendário básico de vacinação infantil. Assim, as múltiplas vivências acerca da (não) vacinação condicionaram sentimentos divergentes, que foram além de questões da vacinação em si e de sua dinâmica no âmbito privado familiar, mas sobretudo, reativas ao contexto temporal e sociocultural.

Os casais que vacinaram seus filhos revelaram sentimento de tranquilidade, tanto perante a decisão natural que tomaram, quanto diante da sensação parental de proteção, de proteger uma doença no filho. Nos homens, mais uma vez, aparecem depoimentos que reforçam a percepção de dever cumprido, responsabilidade e segurança, diante do exercício parental.

Vou ser sincera, cada vacina que eu dou me sinto mais tranquila 'ah, que bom, ela já tomou a da gripe'. Eu sinto sempre uma 
coisa positiva. 'Ah, a Lia já vacinou da hepatite, então ela tem menos chance, da rubéola...' e assim por diante (Jaqueline).

Ah, eu me sinto, me sinto responsável. Ou seja, 'ah, coitadinha, vai doer a perninha, o bracinho', mas essa dor passa. Eu até converso com meus amigos 'puxa, ela vai tomar 3 hoje, puxa vida', mas assim, tem que tomar (Camilo).

Então no geral é uma sensação de segurança. É bom dar as vacinas, ela está bem, reagiu bem, nunca houve nada terrível. Viver é perigoso, então, você tenta melhorar, sabe que tem riscos, mas em geral ela está bem. Então a gente não vê problema nenhum com essa decisão, está sossegado. E provavelmente as vacinas que virão ela tomará também (Alessandro).

Os casais que selecionaram também descreveram uma sensação de tranquilidade e confiança acerca da decisão tomada, com expressões que se repetiram "nós nos sentimos muito bem, confortáveis com isso" (Rafael); "super tranquilos, super feliz" (Francisco) e "a gente se sente super bem, tranquilo assim, nada demais, não ficamos constrangidos" (Manuela). Diante dos depoimentos desse grupo, destoaram o casal Sílvia e Hugo, que sentiram arrependimento por ter dado algumas vacinas ao filho e Isabel, que relatou angústia por ter que assumir a decisão de dar ou não algumas vacinas diante de posturas polarizadas dos pediatras de diferentes linhas terapêuticas.

Eu fico angustiada com o que fazer, como fazer. (...) Mas assim, é angustiante. Até você resolver o que você faz com aquela vacina, sim ou não. Porque parece que tudo é muito grande. Então, a de catapora, que é uma coisa simples, sabe, para os alternativos 'não, porque é muito ruim, por que vai dar?', e os que não são alternativos 'imagina! Por que você não vai dar?', é muito extremo assim, parece que não estão falando da mesma vacina (Isabel).

Os casais que não vacinaram os filhos revelaram sentimentos diversos, às vezes contrastantes. Em poucos desses relatos o discurso da tranquilidade foi veiculado em suas falas, justificado pelo fato de que a decisão deles foi pensada e respaldada em informações acerca do assunto.

Eu estou completamente segura com a decisão, não tenho o 
menor medo de eles pegarem uma doença, morrerem. Se por acaso, se por ventura isso acontecer, eu vou entender que poderia ter acontecido também tomando vacina. Não culpo a vacina ou deixar a vacina por uma questão relacionada à doença (Virgínia).

O que mais sobressaiu neste grupo foram sentimentos de medo, angústia, insegurança e/ou incômodo. Essas sensações não foram porém, decorrentes do medo da doença que deixaram de prevenir em seus filhos, mas do medo de serem julgados, de se sentirem sozinhos nesta tomada de decisão ou de perderem a autoridade e o poder de decisão nos cuidados do filho por alguma entidade pública, como o Conselho Tutelar.

Então, eu fico com medo da pessoa denunciar no Conselho Tutelar e me obrigarem a vacinar. Porque aí ela vai ter que tomar uma dúzia de vacinas de uma vez, não sei qual é o procedimento, mas eu fico com medo. Eu fico com medo só disso, de denunciarem para o Conselho Tutelar. (...) Assim, é o único medo que eu tenho, de denúncia. Porque quanto à saúde dela eu estou tranquila, eu sei que ela está bem, bem cuidada, bem assistida (Amanda).

Mas eu tenho um pouquinho de receio, sim, das pessoas, até pessoas próximas de julgarem essa decisão. Assim como julgam 'ah, tem tatuagem ou você já fez isso ou aquilo', todo mundo julga o tempo todo. Então não que eu esteja insegura da minha decisão, mas eu tenho insegurança das pessoas com a minha decisão (Paula).

Então, a gente acabou optando por não vacinar. Hoje em dia para ser sincero a preocupação maior que eu tenho não é nem de doença, nada. É mais a preocupação legal, porque tem a obrigatoriedade legal de ter a vacinação, mas também acho que isso aí é até questionável judicialmente, se for o caso (Fernando).

Porque por mais que eu tenha decidido não vacinar, às vezes eu ainda fico insegura. Por mais que eu não tenha vacinado, eu ainda tenho uma insegurança em relação a isso, um medo. E eu não sei se esse é um medo meu, se é um medo imposto, se é um medo, que medo é esse, de onde ele vem? (...) Você tem um 
medo 'como é que eu vou me sentir, se acontecer alguma coisa?', 'como é que vai ser para mim?', 'será que eu vou conseguir lidar com isso?' O medo de ser julgada pelo outros, porque tenho muito disso 'ah, o que vão pensar de mim?' E será que o meu marido vai ali nessa hora estar comigo? 'Não, eu estou junto' ou 'ah, eu falei, lembra que eu disse que tinha que ter dado, pelo menos essa da pólio especialmente'. Dá um medo assim animal (Clara).

O meu medo é as pessoas questionarem o nosso poder sobre as crianças realmente. Querer discutir no Conselho Tutelar se essas crianças têm que ficar sob a nossa guarda, entendeu? Isso é um pânico para mim, um pânico. Porque eu sei que se essa discussão se tornar pública, as chances da gente ter um julgamento justo sobre o assunto, não um julgamento na Justiça, o julgamento realmente das pessoas é zero, porque todo mundo vai analisar o problema com base no estereótipo. Mas continuamos tomando essas decisões, porque a gente sabe que é o nosso papel, e a gente tem que tomar essas decisões da melhor forma possível. Mas é um peso grande, entendeu? Porque a gente está sozinho e a gente sabe que são decisões que não seriam apoiadas (Vinícius).

Eu me sinto super tranquila de não ter vacinado, mas eu tenho uma atenção redobrada, eu sei que há um peso maior, acho que eu tenho que tomar mais cuidado com todos os sintomas (...) e isso me cansa um pouco, principalmente pelo Fábio não bancar tanto, aceitar, mas não bancar e saber que se pegar alguma coisa vou ter que tratar imediatamente senão vou ser recriminada (Elaine).

Outro dado inusitado desse estudo foi o teor do medo. Era de se esperar primeiramente que a aflição dos casais que não vacinaram seus filhos fosse decorrente da ausência de proteção dessa ferramenta preventiva que eles abdicaram. Tampouco aparece o medo que as suas decisões privadas pudessem ter alguma consequência coletiva. O que ficou gritante foi o medo de perder a autonomia e a autoridade com o filho. O predomínio desses sentimentos, vividos tão intensamente por esses casais, pode ser compreendido pelo sinergismo do peso da cultura de vacinação no país; da reação ao modo como a vacinação é abordada pela medicina e pela saúde pública e de características específicas desse segmento social. 
Para Hochman (2011), a "cultura de imunização" no Brasil contemporâneo se construiu além de interesses econômicos, do medo de certas doenças e de epidemias específicas e do direito à vacinação, pois esses fatores não dão conta de explicar a oferta e demanda cada vez maior de vacinas, a popularização da imunização, concebida como uma prática social rotineira. Para o autor, a vacinação como cultura no país emergiu com a introdução das vacinas, das campanhas de vacinação e da vacinação em massa no país desde o século XIX, com especial destaque à campanha de erradicação da varíola entre 1967 e 1980.

A estratégia para vacinação em massa nas áreas urbanas, ou com significativa concentração de pessoas, foi a de mobilização da população para grandes encontros em lugares públicos, que marcavam a chegada dos vacinadores e o início da vacinação. (...) Festas populares, romarias, encontros religiosos, feiras, manifestações artísticas populares, quartéis, escolas públicas, paradas de ônibus e grandes empresas foram locais utilizados para vacinação em massa. As equipes deveriam estar preparadas para estender a vacinação até a noite para dar conta de todos os que compareciam. (...) A convocação era feita pelos jornais, alto-falantes, cartazes e filmes nas escolas. $\mathrm{O}$ efeito demonstração se fazia também com a vacinação em público de autoridades, líderes políticos, artistas e esportistas, o que tinha repercussão na imprensa e na população convocada a se vacinar voluntariamente. Essa inovação foi reproduzida depois nos "Dias Nacionais de Vacinação" utilizados para a campanha antipoliomielite no Brasil. (...) Esse processo aumentou o contato da população com os serviços de saúde e a compreensão da vacina como bem público oferecido pelo Estado (Hochman, 2011: 382).

Para Hochman, esses feitos que permitiam aglomerados urbanos numa época em que isso era proibido por um regime político autoritário, foram determinantes para a construção da cultura da vacinação e da visão virtuosa das políticas públicas de imunização no país, intensificada pela percepção, após 1988 com a Constituição Federal, da vacina como um direito (Hochman, 2011).

Esse lugar sócio histórico da vacinação e do PNI no Brasil pode justificar a reação dos casais que não vacinaram e alguns dos que selecionaram, que se sentem sozinhos e acuados perante uma prática mais que hegemônica, consagrada no país. Isso ficou explícito nos seus depoimentos, que revelaram diferentes graus de coerção social, direta ou indireta, tanto do âmbito familiar, quanto do círculo social mais próximo. Essa pressão vivida, quer por experiência própria, quer por ciência de histórias ocorridas com 
pessoas que não vacinaram, foi exteriorizada, sobretudo, pelo medo do julgamento familiar ou social com juízo de ordem moral e de conduta, pelo estigma e estereótipos de serem pessoas não convencionais ou alternativas; e/ou pela ameaça por estarem infringindo a lei. Foi muito citado o medo de denúncia, visita ou intervenção do Conselho Tutelar.

A família é totalmente contra, eles acham que nós somos um ET de outro mundo. Tanto a minha família como a família dela. A minha família é de São Paulo e a dela é de Belo Horizonte. Apesar do meu pai ser primo do pai dela, nós dois somos primos de terceiro grau, então é distante. Mas é a mesma família, e eles acham absurdo. No começo eles enchiam muito o saco da gente, muito. Depois eles viram que a gente não ia abrir mão e pararam de falar. Muita gente critica, e as pessoas de tanto criticar, 'olha, não adianta você falar porque a gente tem opinião formada, a gente desencana' (Diogo).

Meu pai que é mais antigo, meu pai realmente ficou chateado, pressionou muito, desde que Antônio estava na UTI. No comecinho não, porque a gente conseguia usar com ele o argumento que ele era muito pequeno 'ah, é pequeno, mas assim que der você vai vacinar, né?', 'não, vou vacinar', 'e agora, por que não foi ainda?', 'ah, ele está com febre', 'ah, mas passando a febre você vai, né?', e assim, todas as semanas me pressionando porque tinha que levar para vacinar, porque o Ministério Público podia me tirar a guarda, se alguém fizesse uma denúncia. 'Se o posto de saúde fizer uma denúncia, vão te tirar a guarda do seu filho, se eu resolver fazer uma denúncia...' Ele falou só uma vez, 'meu Deus do céu, só faltava essa, a minha família!' Mas não, mas sempre trazendo à tona o que poderia acontecer de muito ruim (Sílvia).

Por parte de amigos também, porque todo mundo vacinou, a gente não vacinou, então 'vocês são loucos! irresponsáveis, tinha que vacinar', aí você contra argumenta o que a pessoa está falando e acabou que ninguém mais comentou nada a respeito, faz tempo que ninguém fala nada a respeito. Se alguém pergunta falo 'não, não vacinamos e por enquanto não vamos'. Mas está assim tranquilo (Fernando). 
Fora a ameaça gigantesca que é das pessoas resolverem interferir nisso. (...) As pessoas podem cismar. O pesadelo da gente é 'não, agora vocês vão dar essas vacinas, vou pegar essas crianças aqui para dar essas vacinas'. E vai entrando em um estereotipo que está sendo criado, como do abandono intelectual, de não colocar a criança na escola. Você pode ser taxado de negligente. É o que acontece com o parto em casa também. Tem mulheres que são visitadas pelo Conselho Tutelar e tudo mais. Tem casos na 'maternas' de mulheres que receberam a visita do Conselho Tutelar e o cara foi com a polícia em casa. Então, a gente também vive essa ameaça, de alguém resolver usar a autoridade contra nós (Vinícius).

Alguns amigos que questionaram por que não. Alguns amigos ficam perguntando por que não vacina, que nós somos meio loucos, meio hippies, meio não sei o quê. Eu falo 'meu, não vacino porque tenho um conhecimento científico ali por trás. Acho melhor não vacinar determinadas vacinas e outras sim e outras não. No Brasil algumas doenças nem tem mais, então, não é necessário vacinar'. Mas a todo o momento, principalmente os mais velhos, eles questionam muito isso, por que não vacinar? Familiares e os mais velhos mesmo. Temos amigos mais velhos 'ah, vocês são malucos e tal'. Mas nós nos sentimos muito bem, confortáveis com isso (Rafael).

Então, tem gente que fica arrepiada só de saber. Tem gente que acha que a gente é doido, que já tem essa imagem da gente 'ah, mas vocês são doidos'. Minha professora lá da faculdade, estava conversando, a gente chegou nesse ponto da vacina, 'ah, mas o Mateus não tomou nenhuma vacina', 'ah, eu tinha certeza que vocês iam fazer isso, tinha certeza que ia ser assim, já esperava isso de vocês'. Mas eu acho que a imagem, a reação, o impacto que essa informação da não vacinação nessa idade do Mateus, dá para as pessoas que é uma coisa exótica, em geral é exótico, irresponsável para outras, é loucura para alguns (Francisco).

Eu fui tomar posse do meu cargo público e eles pedem a carteira de vacinação do filho. Aí eu falei 'olha, a carteira de vacinação do meu filho está aqui, mas ela não está completa', aí a moça falou 'ah, pessoal da homeopatia?' Não tem nada a ver com homeopatia, não faço homeopatia (Cláudia). 
Os dados empíricos desse estudo estão de acordo com a hipótese de Hochman (2011), que a cultura da imunização no Brasil se mostrou soberana na influência de vacinar ou de temer por não vacinar os filhos, em comparação com o peso da obrigatoriedade da vacina por lei. Isso porque a questão legal pouco apareceu nos relatos, acrescido do patente desconhecimento sobre a lei e normatização do Estado frente à vacinação no país, incluindo o ECA.

Então, eu, por exemplo, achava que era obrigatório, que a criança tinha que tomar todas as vacinas, na data, seguindo a tabelinha do Ministério da Saúde e tal. Daí eu fiquei sabendo que não (Francisco).

É a primeira vez que eu penso sobre isso, não sei até se algumas vacinas não deveriam ser por lei, tipo não é opção do pai, tem que dar e pronto. Eu tenho uma tendência a ser contra esse negócio de ser alternativo, mas se não afetar a minha família, as pessoas que eu gosto, não vou na passeata favorável à vacina. Não vou levantar nenhuma bandeira (Guilherme).

Além da cultura da imunização no Brasil, que ocasiona a coerção social vivida por esses casais, outro fator importante encontrado nos relatos foi a maneira como a vacinação costuma ser abordada pelas pessoas em geral e pelos profissionais da área da saúde e governo. A temática da vacinação e o desenho da política pública de imunização estavam num patamar de pouco ou nenhum espaço para interlocução, debate ou questionamento. O vácuo ou abismo dialógico nesse assunto foi referido por esses casais tanto por parte de pessoas da família e ambiente social mais próximo, quanto por parte da maioria dos profissionais de saúde. Eles encontraram esse espaço com pessoas que também não haviam vacinado seus filhos (de forma pessoal ou virtual em redes sociais do movimento da maternidade ativa ou específico contra a vacinação) e com alguns profissionais de linhas terapêuticas da antroposofia, homeopatia ou pediatria humanizada.

A falta de diálogo mais aberto sobre vacinação infantil com os médicos, com a intenção dos profissionais transmitirem informações técnicas "seguras" (que permita, inclusive, confrontá-las com as encontradas na internet) e assim, ajudar os pais a terem um embasamento teórico que facilitassem e norteassem as escolhas sobre a vacinação do filho foi relatado por Vinícius. Diferente de outros assuntos como parto, alimentação, 
educação etc., em que se encontram espaços e profissionais para interlocução, com múltiplas visões sobre determinado assunto, o mesmo não foi encontrado para a vacina, culminando em profissionais com postulados de forma polarizada, contra ou a favor; ou ainda, falas de cunho da experiência pessoal, se distanciando da dimensão técnica.

Os médicos ficam em uma situação muito delicada, porque eles não podem dizer 'não vacine', que outro problema é o clima em relação às vacinas. Você vive em um ambiente de lavagem cerebral em relação às vacinas. Então, os médicos não dizem. Só que aí quando você adia, eles falam 'bom, já que você adiou, tem tal, tal, tal, que não precisa mais dar, porque já passou do tempo. Tem não sei o que, não sei o que, entendeu?', então no final das contas adiar implica deixar de lado algumas, que são aquelas primeiras. A gente tem umas indicações de médicos, porque na verdade o que eu queria era a tabela de riscos e decidir, essa vai, essa não vai, essa não vai, com ajuda de um especialista. Só que você não encontra esse especialista. Existem médicos que se posicionam sobre isso. Mas é uma coisa que eles fazem quase não como médicos, entendeu? É uma coisa de confessionário. Eles falam como pais ou como mães. No final o que eles dão é um testemunho, 'olha, eu nos meus filhos eu dei tal e tal e não dei as outras'. Você não tem uma resposta profissional, você não tem uma consultoria. Você tem um outro pai dividindo com você uma decisão incerta que ele tomou. Então, essa é uma coisa muito incômoda, muito incômoda (Vinícius).

O pouco espaço e o lugar de inquestionabilidade da vacinação foram percebidos pela maioria dos casais desse estudo, mas de maneira diferente. Nos pais que vacinaram seus filhos, a aceitação e confiança nessa prática se revelou como algo que não precisa ser debatido ou questionado por eles. Já a maior parte dos casais que não vacinaram ou selecionaram as vacinas, a dificuldade em encontrar interlocutores e um espaço seguro para debate e reflexões transparentes (sobrando apenas informações aleatórias na internet, grupo de pais já tendenciosos contra a vacinação e alguns profissionais de linhas terapêuticas não convencionais), fez com que eles criticassem a inquestionabilidade da vacinação. Esse cenário exemplifica o que Moulin (2003) descreveu, o reducionismo de uma questão complexa, o universo da vacinação, numa polarização de correntes extremistas contra e a favor. Tal a magnitude desse lugar inquestionável socialmente construído, que a vacinação foi associada a um dogma ou comparada com religião por alguns participantes. 
E basta um olhar atento e pesquisar sobre o assunto. Você vê fora do Brasil muito mais noticiário do que aqui. E quando acontece um caso [efeito adverso à vacina], que é logo depois da criança ter tomado vacina, ela já tem alguma coisa, ninguém culpa a vacina. E falam que deve ter sido alguma outra coisa, que a criança tinha doenças anteriores e porque aí a doença matou. Mas nunca se associa à vacina. Parece que a gente foi condicionado a acreditar que a vacina é tão boa, que é hiperinquestionável. E isso para mim é o maior fator temerário, porque a gente não questiona e aí a gente vai igual burrinho de presépio, fazendo tudo, né. E não é só os pais, acaba toda a sociedade acreditando nessa falácia na minha opinião (Virgínia).

Aí você vai ter que se explicar para um sistema que é assim, não compreende que você tem que tomar essa decisão. Dá como sendo certo, que tem que tomar e acabou. Mesmo as novas, essa da gripe, é uma vacina nova, você não tem nenhum apoio da tradição, de dizer 'não, eu tomei quando era criança, não tive nada, então posso dar na minha filha.' Não, então a gente fica acuado realmente.

\section{(...)}

A situação é muito difícil porque você tem as informações sobre os riscos e do outro lado você tem todo um sistema meio cego para o problema. Tem pessoas que não questionam porque acham que tem que dar mesmo, e não tem discussão. E no máximo, você encontra algumas pessoas que te dão algumas orientações vagas, entendeu. Então, isso também provoca um retraimento, porque se o sistema fosse um pouco mais racional, o sistema público, a crença geral sobre o assunto, a gente pelo menos teria mais liberdade para trocar com as pessoas. Mas como essas pessoas na verdade não tem nenhuma intenção até de discutir o assunto, mesmo sendo vacinas novas, as pessoas tratam da mesma forma, naturalmente a gente rompe com isso, entendeu? Porque a gente não tem escolha, as pessoas não oferecem diálogo em relação a esse assunto. É uma coisa dogmática, e a nossa situação não permite que a gente se agarre a dogmas. (...) Então, a coisa natural é a gente se isolar, e buscar alternativas assim, nos mais diversos, por exemplo, eu considero seriamente a possibilidade de... Nós temos a questão da cidadania dupla, italiana. Eu acho isso uma alternativa, pela possibilidade de encontrar ambientes que isso possa ser 
discutido de maneira mais racional (Vinícius).

Às vezes tenho amigos que decidiram vacinar os filhos e que não se informaram e que acharam 'Não, isso é certo. $E$ você, vacinou?' 'Não', e morre ali, eu não entro em discussão com alguma amiga que vacinou e elas não entram em discussão porque eu acho que é uma coisa muito, quase como religião, religião não se discute, futebol, e vacinação vai ser o próximo. Não se discute porque é muito polêmico, é muito polêmico (Clara).

Então agora faz todo sentido as opções que eu fiz na vida, e se os meus filhos acharem que não está bom, eles têm todo o direito de ir lá e tomar vacina. Quando eles forem maiores, eles podem optar por religião ou vacina, por se tratar com homeopatia ou alopatia, ou com outra medicina que eles quiserem, por enquanto eu cuido deles da maneira que eu acredito, mas não sou fechada pra nada, a qualquer momento, pode haver novas informações que podem fazer eu mudar de ideia (Elaine).

Quando eu comecei a ler sobre vacinação, até ouvi, uma vez perguntaram 'o que você acha de vacina?', e a pessoa respondeu 'vacina é que nem religião, não discuto esse assunto' (Paula).

Agora, vivendo em São Paulo hoje, acho que poderia haver alguma flexibilidade com esse calendário como está posto, e poderia haver mais debate com relação a isso (Sílvia).

Apesar dessas falas expressarem a opinião que o dogmatismo está atrelado apenas às vacinas e ao ato de vacinar, os depoimentos de alguns casais que não vacinaram exprimiram a visão e postura da não-vacinação como algo certo, às vezes indiscutível ou tão estabelecido, que pode ser lido como uma posição dogmática, porém, às avessas.

Assim, a cultura da vacinação e a ausência de espaços e pessoas para diálogo e reflexões sobre o assunto no país corroboraram para a sensação de medo de perderem a autonomia e autoridade perante o filho. Isso se intensifica, por fim, pela própria característica da camada média urbana escolarizada. Nesse segmento social, como 
destacou Velho $(1987,1994)$, a trajetória biográfica dos sujeitos é construída a partir de projetos diante de um campo vasto de possibilidades. Nesse processo individualizante, a autonomia e a liberdade de escolhas se tornam valores e identidades marcantes que, quando abaladas, geram desconforto e reações. Essa característica vai de encontro com as ideologias da maternidade ativa, do empoderamento e do protagonismo sobretudo da mulher (re)assumir a responsabilidade do cuidado materno-infantil de um modo geral e nos aspectos de saúde.

O Diogo quando ele se convenceu do parto em casa, ele saiu contando para todo mundo. E a mesma coisa ele fez com a vacina, ele saiu contando para todo mundo, até o dia que eu falei 'você quer um oficial de justiça na sua casa?' Aí ele 'ah? Mas é assim?' 'Sabe o que é ECA? 'Não', Então... 'olha, muito legal quando você abraça a causa, só que a gente, infelizmente, nem todo mundo concorda com o que a gente concorda, e principalmente a gente tem ainda leis no Brasil que não te dão total decisão de fazer com o seu filho o que quiser'. Deveria ser assim, as leis deveriam prevenir atrocidades como pais espancando filhos, essas coisas ruins continuam acontecendo. Eu acho que está no caminho para poder chegar em um bom momento. Com relação à vacina ainda não, porque eu acho que precisa uma mobilização maior (Virgínia).

Mas eu acho que o respeito dentro da minha casa, é uma decisão minha, eu sou mãe. Vamos fazer um teste psicológico para provar que eu não sou insana, que estou escolhendo alguma coisa. Tem gente que fuma e tem gente que não fuma (Paula).

Então a sociedade generaliza tudo isso. Só que eu acho que eu tenho condições de tomar decisões, mesmo que nem sempre sejam acertadas, mas pelo menos parar para pensar, e individualizar. 'Não, cesárea não é a melhor solução para mim', 'ser onívora não é a melhor solução para mim, para meus filhos tampouco', tratar doenças de uma determinada forma, ir para uma determinada escola. (...) Então, é tomar para si a responsabilidade que na verdade é minha mesmo, não é do governo, não é de ninguém. Nossa como pais, como família. Então, acho que nisso que me baseei para decidir essas coisas (Andreia). 
Porém, a autonomia valorizada por essa camada social, que permite a ideação de singularização diante de um calendário básico vacinal posto de forma generalizada pela biomedicina e saúde pública, não foi estendida pelos participantes do estudo como um bem para todos os sujeitos, um bem do ser humano. Balizado no argumento que a vacina tem sentido para pessoas que têm uma condição de vida desfavorável, na visão de alguns entrevistados que não vacinaram os filhos, as famílias pobres estariam expostas a doenças imunopreveníveis que suas famílias não estariam e, portanto, não vacinar ou escolher as vacinas só fazia sentido diante do modo de vida que eles tinham, exemplificado pela boa moradia, saneamento básico, amamentação prolongada, saúde do filho fortalecida pelo amor, carinho, alimentação natural etc.

O preconceito de classe ficou evidente no olhar de alguns casais, que veicularam nos seus depoimentos, além da concepção que o risco de pegar doenças imunopreveníveis era maior ou quase exclusivo da população de baixa renda, que a não vacinação da camada popular era diferente da não vacinação deles, pois a decisão deles era baseada em estudo e informações, acrescido pelos fatos de seus filhos terem boa saúde e acesso a bons serviços médicos, diferentemente dos pobres. E mais, os relatos de alguns participantes expressaram "dois pesos e duas medidas" no tocante à transmissibilidade de doenças preveníveis por vacina, ou seja, não foi relatado que a não-vacinação deles poderia provocar a doença na população mais carente, mas houve falas que insinuaram que algumas doenças vêm da pobreza e más condições socioeconômicas e era isso que poderia por em risco a saúde de seus filhos.

Desse modo, para alguns casais que selecionaram ou não vacinaram seus filhos, o risco de doenças imunopreveníveis em seus filhos não foi interpretado como oriundo da não vacinação infantil que eles próprios escolheram. Essas percepções explicitam a desigualdade de classe introjetada numa parcela da população de camada média, que expressa direta ou indiretamente, um olhar e uma posição de superioridade. Para estes, deter a autonomia das ações e decisões em saúde ou cuidado infantil não foi estendida a toda população, relativizando seletivamente a autonomia.

Ele não consegue entender que todo mundo toma tudo porque é pensado no geral da população, não em casos específicos, não há um plano do governo de falar assim 'olha, você que mora na região tal e frequenta a classe tal, você tem que tomar tal vacina', não existe isso, existe 'vamos tomar todo mundo todas' 
(Elaine).

Eu fico pensando que a vacinação de um modo geral pode ser necessária, pode ser útil em alguns casos. (...) Tem uma indicação em casos específicos de epidemia, indivíduos que tem problemas de imunidade, que estão com algum problema. Aí eu pensei, realmente, em alguns casos a vacinação pode ser útil, por exemplo, uma população que mora, o problema é outro, em favela. A pessoa que mora na favela, na beira de um esgoto, a céu aberto. Com a cabeça que eu tenho hoje, se eu morasse em um lugar assim, eu ia pensar 'não, eu acho que a vacina da pólio é interessante' (Amanda).

$\mathrm{Eu}$ até entendo a postura do governo de ser obrigatório a vacinação, porque a gente... 90\% da população não têm as condições que nós temos. Então, acho que até a postura do governo é correta nesse aspecto, porque a gente não está na Bélgica, na França. Então, tem gente que mora em condições precaríssimas. O Brasil é imenso, gigantesco, então, eu até entendo a postura do governo de ter um calendário obrigatório de vacinas. Mas eu acho que a gente tem condições e conhecimento de optar ou não pela vacinação. Pelo que for melhor para o nosso filho, né. Não de forma irresponsável, claro. Tanto é que a gente procurou bastante coisa a respeito. $\mathrm{E}$ acabou conscientemente optando por não vacinar (Fernando).

Diante da confluência desses aspectos - a cultura brasileira da imunização, o pouco espaço para diálogo e a busca pela autonomia nos cuidados gerais e em saúde do filho característico desse segmento social - o caminho reativo encontrado por esses casais foi o silêncio e isolamento nesse quesito perante seu círculo familiar e social e a busca por um apoio ou legitimidade de sua escolha por médicos que defendem a não vacinação ou a vacinação de forma singularizada. Dessa forma, muitos dos casais que selecionaram ou que não vacinaram seus filhos reagiram com uma postura de não compartilhar essa decisão com outras pessoas, exceto para os pares que se sabia previamente que também não vacinavam suas crianças. Como expressou Vinícius, "eu trato isso [a não vacinação] como uma coisa sigilosa".

Mas a gente não deixa ninguém saber no nosso dia a dia da questão de vacinação, pelo que existe de preconceito, alguém pode denunciar, a cabeça do ser humano é muito complicada, 
pode assustar. (...) Agora, para as pessoas que não são da nossa família, que são do nosso relacionamento, de amigos ou de trabalho, a gente não fala, a gente resguarda. E aí o ambiente da Virgínia, das listas dela de e-mail, as listas de discussão, são só as pessoas que fazem da mesma forma, que agem da mesma forma, e estão também na clandestinidade que rola esse negócio. $\mathrm{O}$ pediatra que atende eles, a médica homeopata, tudo mais ou menos a mesma linha, então o papo acaba sendo o mesmo. Aqui no prédio tem muitas crianças e ninguém sabe que eles não são vacinados (Diogo).

E aí com essa história da vacina eu não falei para ninguém. Eu não comentei com ninguém, ele não tomou nenhuma vacina e eu acho que não é uma coisa que você tenha que ficar contando. Se alguém perguntar eu falo 'não é vacinado ainda', 'por quê?' Aí dependendo da pessoa eu vou falar 'ah, não, porque eu fui na, eu levei ele na igreja e disseram que não podia vacinar ainda'; dependendo da pessoa eu vou falar 'ah, eu tenho lido, tenho estudado e achei melhor não dar. Você já estudou sobre isso?' Depende se tem filho, se não tem filho. Tem pessoas que não dá para você discutir. A pessoa vai te massacrar de qualquer jeito. (...) Mas no fundo, chega uma hora que você fala assim 'o filho é meu, decidi e ponto'. Se você começa a abrir muito, divulgar muito, as pessoas começam a achar que fazem parte da sua vida e que podem também palpitar e decidir por você (Paula).

A gente não conta para ninguém, a gente não comenta. (...) Então a gente só comenta no meio que a gente tem muita confiança mesmo. Então por isso toda a reserva, o cuidado e tudo mais (Ana).

E eu não falo sobre isso. Falo mais do meu parto e as pessoas perguntam muito mais do que da vacina. Eu não conto para as pessoas que o Mateus não está com a carteira de vacinação completa. Eu acho que para as pessoas é uma coisa tão óbvia que nem perguntam (Cláudia).

Ele [o avô da criança, pai dela] não sabe que a gente parou com o calendário, não se fala mais nisso com ele. Foi outra lição que a gente teve, que tem algumas pessoas que você pode falar e 
outras pessoas com as quais se perguntar 'está tudo bem?', 'está tudo bem', 'e as vacinas?', 'tem, está tudo em ordem', e é isso, tem gente com quem não pode conversar. (Sílvia)

Outro dado inusitado desse estudo é a ausência de falas mostrando a função coletiva da vacinação. Isso não ocorreu apenas nos casais que não vacinaram ou que selecionaram as vacinas, cujas decisões de não vacinar podem propiciar brechas na imunidade coletiva, com bolsões de susceptíveis e o retorno de doenças previamente controladas, como é o caso dos recentes surtos de sarampo no país (CVE, 2014), e o risco teórico de retorno da poliomielite, uma vez que esta doença pode ser exportada de países que ainda tem circulação do vírus selvagem (CGPNI, 2014). A não percepção que o ato de vacinar a criança tem uma função social também ocorreu nos casais que vacinaram.

Apesar do roteiro dessa pesquisa não ter contemplado o aprofundamento da concepção coletiva e individual da vacina para os casais pesquisados, esse indício de silêncio sugere que a escolha de vacinar ou não é norteada quase que exclusivamente pelo âmbito individual. Para a maioria deles - respondendo perguntas mais abertas e menos direta de como eles viveram o processo da (não) vacinação dos filhos - portanto, não apareceu a ponte que relaciona sua decisão e a influência direta na coletividade, estimulando a favor ou contra a circulação de doenças imunopreveníveis na perspectiva da imunidade de rebanho. Foram identificadas apenas duas falas que abordam esse assunto. Cláudia relatou, referindo-se à fala do pediatra humanizado de seu filho, a importância coletiva da vacina, que influenciou sua escolha. Outra fala veio da percepção de Clara, que revelou justamente o inverso do princípio da imunidade coletiva, ou seja, a sua escolha pela não vacinação do filho não aparece como um possível risco ao coletivo, mas o contrário, é a vacinação do coletivo que pode levar risco ao seu filho, devido à transmissão do vírus vacinal da poliomielite oral pelas fezes (Plotkin et al., 2008).

Então se vacina, na verdade todo mundo está meio que protegido, não só quem vacinou está protegido, por isso que o Clécio [pediatra] falou 'olha, vacinar é um ato social, não social, é um ato quase político', assim dizer, 'meu filho participa disso'. Então, se todo mundo participa ele está protegido. Ao mesmo tempo se ele não participa é uma brecha que ele dá para a doença entrar na sociedade, então, tem muito mais a ver com o 
universo da saúde pública e coletiva do que individual (Cláudia).

E essa coisa de 'ah, que perigo, o seu filho não tomou vacina, ele é um risco para a sociedade'. Meu filho é um risco? Meu filho que não tomou a vacina é um risco? Não, o seu filho que está tomando é um risco para o meu filho, porque você pode passar para o meu filho essa doença que está carregando de lá pra cá. Você está lá, você deu a vacina de pólio para o seu filho, e daí a tantos vai sair no cocô dele, o germe pode sair ainda ativo e meu filho pode estar lá na escolinha com o seu filho e ele sem querer botar na boca e aí? E como é que fica o meu filho, entendeu? É tanta coisa que envolve, não é só dar, a pessoa não pensa em tudo isso, em todas as implicações. E eu penso... (Clara).

Na perspectiva da vulnerabilidade (Ayres et al., 2012), já é conhecido que algumas doenças preveníveis por vacina, por meio dos seus determinantes econômicos e sociais, sofrem influências na incidência, prevalência e no prognóstico conforme as diferentes condições de vida, nutrição, acesso aos serviços de saúde etc. Mas se para esses casais que não vacinaram, algumas doenças imunopreveníveis são entendidas como benignas, de fácil manejo ou desnecessária pelo seu nível de vida; o mesmo não se pode dizer da hipótese dessas mesmas doenças, que estão controladas, atingirem a população mais vulnerável. O pior é a ausência de conhecimento da corresponsabilidade que a decisão privada de não vacinar pode acarretar no nível populacional e em indivíduos mais vulneráveis.

Isso pode ser exemplificado pelos surtos de sarampo nos anos 2000 no país. O sarampo autóctone - ou seja, circulação do vírus selvagem originário do próprio país estava controlado no Brasil desde 2001, havendo relatos de surtos cujo caso índice tinha história de viagem ao exterior. Embora houve queda dos casos de sarampo no mundo, em 2013 foram registrados aumento de casos na Alemanha, Itália, Holanda, Romênia, Reino Unido dos quais 8 evoluíram com encefalite e 1 com óbito (CVE, 2014). Em 2013, o Brasil registrou 211 casos de sarampo, sendo que cinco ocorreram no Estado de São Paulo. Em todos os casos deste Estado, houve histórico de viagem recente ao exterior ou comunicação indireta com os viajantes. Assim, no caso específico do sarampo, está predominando o perfil de pessoas que viajaram para fora do país ou que tiveram contato com o caso índice. Devido a sua alta transmissibilidade, a entrada do 
vírus no Brasil pode alcançar bolsões de falha vacinal ou pessoas com imunodeficiência ou com contraindicação à vacina e atingir uma população com maior vulnerabilidade em comparação com aqueles que decidem intencionalmente por não vacinar e bancam as possíveis consequências dessa decisão apenas no interior de sua família. Isso pode ser exemplificado pelo único caso de óbito por sarampo no Brasil em 2013, em Pernambuco, de uma criança de 7 meses em condições de imunossupressão (CVE, 2014), faixa etária e situação de saúde que contraindicam a vacina MMR.

A vacinação e a sua interface individual-coletiva, ou seja, a proteção do indivíduo e a imunidade coletiva pela qualidade da imunidade de rebanho (Plotkin et al., 2008), se diferencia da maioria das dimensões saúde-doença estudadas no nível populacional, em que o risco de uma doença numa determinada população é calculado pela média dos riscos das doenças individuais, como por exemplo o colesterol elevado. Com a imunização, "existem características nas populações derivadas das propriedades dos indivíduos, mas que também existem as verdadeiras características de nível populacional" (Rose, 2010: 38). No livro de Geoffrey Rose "estratégias da medicina preventiva" foi salientada a peculiaridade da imunidade coletiva pela vacinação:

O efeito do padrão de imunidade de um indivíduo e seu risco de doença depende do padrão de imunidade dos indivíduos a sua volta. Se um número suficiente de pessoas está imune em uma comunidade fechada, então o número de susceptíveis é tão baixo que não sustenta a transmissão do agente infeccioso. Assim, os indivíduos não imunes estão sob baixo risco devido à característica de nível comunitário nível da imunidade coletiva. É quase o contrário do exemplo do colesterol. Não é o padrão de "risco" do indivíduo que determina o seu risco individual. De fato, nem o nível de risco populacional é a simples soma dos riscos individuais, embora o número de indivíduos imunes contribua de um modo não linear para o nível de risco populacional. Em outras palavras, existe uma característica em nível social, uma imunidade coletiva que é derivada do risco individual, mas que pode ser considerada uma propriedade que emerge da sociedade (Rose, 2010: 38).

Dessa maneira, há um paradoxo no tocante à classe social: os estratos de menor nível socioeconômico foram os que tiveram maior cobertura vacinal em São Paulo (Barata et al, 2012), e assim, dessa maneira, foram os responsáveis pela maior contribuição para a imunidade coletiva, protegendo pela via indireta a população mais ampla, incluindo a de maior nível socioeconômico e escolaridade. Em contrapartida, são estes últimos, aqui exemplificados pelos casais de camadas médias urbanas e alta 
escolaridade, em que se encontrou uma tendência de queda da cobertura vacinal e famílias que escolheram não vacinar os filhos, asseguradas pelo modo de vida e acesso à saúde, que contribuem para bolsões de falha vacinal e risco de recirculação de doenças previamente controladas por vacina que, por sua vez, poderão gerar maiores consequências, com mais impacto na morbidade, gravidade e sobrevida, justamente na população de maior vulnerabilidade, que a protege.

A autonomia de escolha pela (não) vacinação irá repercutir no paradoxo da prevenção descrito por Rose (2010: 79), que diz poder "haver um conflito entre interesses coletivos - que requerem uma ampla mudança na comunidade - e os daqueles muitos indivíduos envolvidos, que poderiam considerar que suas perspectivas de benefícios não são significativas". É importante chegar aos pais de todas as camadas sociais que a vacinação infantil tem uma ação coletiva além da individual, e assim, que as decisões individuais poderão refletir na sociedade mais ampla e em pessoas de maior vulnerabilidade. Mas como conciliar liberdade de escolha e autonomia sob uma intervenção que incide no corpo individualmente com uma normatização com repercussão coletiva?

Resgato, para finalizar, uma das propriedades do cuidado de Ayres (2004), a responsabilidade, em que o ato de cuidar só se corporifica ao responsabilizar-se por si ou por outrem. "Cuidar não é só projetar, é um projetar responsabilizando-se; um projetar porque se responsabiliza" (2004: 78). Assim, o cuidar em saúde, que é sempre relacional, poderia alcançar outro patamar diante da crise de confiança e legitimidade da medicina tecnológica (Schraiber, 2008): a interação de pessoas e grupos com profissionais de saúde e gestores, por meio da aproximação dialógica, pautada também na apreensão que o responsabilizar-se não está só na esfera privada (consulta médica, cuidado do filho no interior da família etc.), mas também na coletiva que, por outro lado, representa mais que metas de cobertura vacinal a se atingir.

Assim como a consciência da ação do humano ao meio ambiente, cuja percepção de responsabilização individual-coletiva-institucional está cada vez mais introjetada no imaginário das pessoas nas últimas décadas (Barbieri JC, 2011), as reflexões sobre as vacinas e a vacinação em massa poderão avançar na compreensão da característica individual-coletiva das vacinas, um fenômeno complexo sócio histórico, de seu caráter movente e conflituoso, em que ações e reações médicas e sociais sobre a 
temática deveriam agregar a dimensão da responsabilização coletiva, mesmo diante do ethos individualizante das sociedades complexas contemporâneas (Velho, 1994). 


\section{CONSIDERAÇÕES FINAIS}

O percurso desse estudo foi de cunho reflexivo, cuja finalidade foi compreender o processo de (não) vacinação dos filhos e sua interface com o cuidado infantil por casais de camadas médias de São Paulo. Esse recorte permitiu enriquecer e abrir a discussão sobre as tensões e confluências acerca das vacinas e da vacinação infantil e não responder ou fechar questões. Em outras palavras, possibilitou lançar ideias para o debate e subsídios para novos estudos.

O cenário contemporâneo no tocante às vacinas é muito diferente do início do século XX, palco de revoltas contra o autoritarismo da vacinação em massa compulsória, como a Revolta da Vacina em 1904 (Sevcenko, 1993); e também das circunstâncias das décadas de 1960, 1970 e 1980, em que os resultados da redução das doenças imunopreveníveis eram visíveis, resultando na "cultura da imunização" no país (Hochman, 2011). Apesar da validade científica que se consolida no decorrer do tempo, da eficácia revelada na experiência de longa duração e das novas tecnologias e descobertas na área da vacinologia, novas perguntas e questões continuam se apresentando nesse campo, como: é preciso continuar vacinando as crianças de doenças que estão controladas na atualidade ou o controle decorre justamente da vacinação em massa permanente dessa população? Isso vale para todas as doenças imunopreveníveis? Como manter uma política pública de vacinação em massa no momento atual de percepção de controle epidemiológico das doenças e de maior visualização dos seus efeitos adversos? Em 1977, o calendário para a criança de até um ano contemplava a proteção de seis doenças ${ }^{25}$; na atualidade esse número triplicou para 18 doenças ${ }^{26}$ (Domingues; Teixeira, 2013; CGPNI, 2013 a, b e c). Diante disso, como será o calendário vacinal infantil em 30 anos? Todas as vacinas que vierem a ser desenvolvidas deverão ser incorporadas no calendário básico de vacinação? Que eventuais repercussões esse crescente número de vacinas, doses e antígenos podem acarretar à saúde da criança? Como lidar com a problematização em torno da vacinação, tanto no ambiente da clínica, quanto no âmbito da saúde pública e coletiva?

\footnotetext{
${ }^{25}$ Vacina BCG, vacina contra poliomielite oral, DTP (difteria, tétano e coqueluche), sarampo.

${ }^{26} \mathrm{BCG}$, contra hepatite B, difteria, tétano, coqueluche, Haemophilus influenzae B, rotavírus, poliomielite, pneumococo, meningococo $\mathrm{C}$, sarampo, caxumba, rubéola, gripe e febre amarela (esta não de forma universal, apenas para áreas de risco) para crianças de até 1 ano. Mais varicela, hepatite A e HPV para outras faixas etárias.
} 
Diante desse panorama, a reflexão neste estudo foi orientada pelo trabalho de Moulin (2003), que propôs superar a compreensão de resistência ou rejeição às vacinas, que abafa a dimensão social e evidencia o poder das normatizações médicas, para a de aceitabilidade, dando voz aos sujeitos e, assim, permitir a apreensão das ações sociais, da diversidade e do dinamismo na articulação saúde e sociedade (Donnangelo, 1976).

A contribuição da perspectiva socioantropológica no processo saúde-doençaintervenção enriqueceu a compreensão: sobre as relações existentes entre as pessoas que fazem parte de uma mesma camada social, com uma única técnica médica, a vacina, bem como sobre o peso da "cultura da imunização" no país, que se refletiu na coerção social e em ações e reações de pessoas e grupos. Essa perspectiva, além disso, possibilitou apreender que a cultura também está nas práticas médicas, na resistência (pela visão de alguns participantes de pesquisa) de interlocução, na crença "dogmática" atribuída à vacinação e à não-vacinação, nos valores e práticas que ora são rejeitados, ora são resgatados, como o enaltecimento da dimensão biológica do corpo feminino, que impulsionou uma reafirmação identitária de certas mulheres nos movimentos da maternidade ativa e parto ativo, entre outros aspectos analisados no estudo.

Reforçada pela escolha metodológica, buscou-se estudar o objeto de pesquisa diante de sua diversidade de sentidos nas camadas médias paulistanas e não ante sua distribuição na população mais ampla. Essa camada social - que não tem sido um objeto prioritário nas pesquisas na área da saúde pública/coletiva - se revelou nesta pesquisa um segmento social que, por um lado, reivindica e batalha por acesso a tecnologias de saúde e, por outro, mostra-se pioneiro na crítica ou contestação a algumas técnicas e normatizações médicas apoiadas e acreditadas em outros contextos sócio históricos. Os dados desse estudo permitiram indicar tendências presentes no universo simbólico dos casais participantes, relevantes devido à influência dessa classe social como exemplo ou referência em inovação, crítica ou perpetuação de valores e práticas a outros segmentos da sociedade (Velho, 1987).

Os achados deste estudo revelaram a relação da (não) vacinação infantil com as práticas de saúde vigentes, com transformações na esfera da família e da sociedade mais ampla na contemporaneidade. No âmbito das práticas de saúde, destaco em primeiro lugar o protagonismo da mulher no processo de problematização das vacinas, como resposta à violência sofrida pela medicalização do corpo feminino e pelas práticas 
hegemônicas obstétricas hospitalocêntricas e patologizantes (Tornquist, 2002; Diniz, 2005; Vieira, 2008). Em segundo lugar, o paradoxo epidemiológico, em que o sucesso das políticas públicas de imunização acarretou a sensação de controle dessas doenças e a maior visibilidade dos efeitos adversos, ressignificando os valores tradicionalmente atribuídos às vacinas.

No universo familiar, os dados apontaram a perpetuação da reprodução do cuidado em saúde como atributo feminino e o lugar central que a criança assume na família contemporânea. A valorização da biografia do filho, característica da camada média urbana - construída no sinergismo entre seguir o modo de vida familiar e estimular a singularidade da criança (Velho, 1987) -, revelou-se importante para a concepção desses casais de que as decisões sobre a saúde infantil, incluindo a vacinação, devem ser realizadas com autonomia e no âmbito privado. Nessa lógica, para todos os casais participantes, a escolha pela vacinação, seleção ou não vacinação foi referida como parte inerente ao cuidado parental, expresso pela mesma ordem simbólica de parentalidade: dever, proteção e responsabilidade com o filho.

No que tange a transformações mais amplas da sociedade, a escolha da (não) vacinação foi norteada pela lógica individualizante; sustentada por argumentos com legitimação e validação científica; que diante do ethos da "sociedade de risco" (Beck, 2010), se conformou com a gestão individual e o desejo de controle do risco. A informação em saúde pela internet e pelas redes sociais foi apontada pelos participantes desta pesquisa como a principal responsável pela mudança paradigmática na relação dos sujeitos com sua saúde e com a saúde de seus filhos.

Nesse amplo e complexo contexto de interface saúde-sociedade, esse estudo propôs refletir sobre os achados a partir da perspectiva do cuidado de Ayres (2003, 2004), buscando valorizar a diferença, a voz e ação dos sujeitos e o aspecto relacional dialógico (Deslandes; Ayres, 2005). Sendo os sujeitos seres singulares e sociais, a aproximação dos profissionais de saúde/gestores com pessoas/grupos pode se beneficiar com a criação de espaços de interlocuções, em que posições divergentes possam ser consideradas sem punição, prejulgamento ou culpabilização.

É justamente pela possibilidade de reconhecimento do outro como uma alteridade, que o diálogo pode se estabelecer (Sarti, 2003). Ao invés de jargões militarizantes como "vamos combater o sarampo", "vamos juntos na luta contra o 
câncer pelo HPV"; autoritários como "tem que dar todas as vacinas", ou do vácuo dialógico pela inquestionabilidade cultural associada à vacina na biomedicina e na saúde pública; a aproximação com esses sujeitos que não vacinaram - que estão escondidos e num processo solitário, mesmo diante de pares que partilham dos mesmos projetos - pode ocorrer por meio do aumento dos espaços de conversas e debates. $\mathrm{O}$ encontro entre os saberes técnicos sobre a vacina com os saberes práticos dos sujeitos e grupos (Ayres, 2003, 2004) pode diminuir a desconfiança da prática da vacinação, a angústia perante a pluralidade, superficialidade e às vezes equívocos das informações sobre vacinação na internet e, sobretudo, o compartilhamento da função social da vacina às coletividades.

Os achados dessa tese permitem recomendar a transferência da culpabilidade, do julgamento de negligência dos pais, da polarização e postura autoritária para a aproximação dialógica que permita resgatar a característica individual-coletiva das vacinas e, por conseguinte, o reconhecimento da corresponsabilidade e de que eventuais surtos ou o retorno de doenças preveníveis por vacina não seja um fato isolado ou independente de ações tomadas em nível individual. Sugerem, ademais, que as propostas de empoderamento (Carvalho, 2004), singularização e autonomia em saúde (Campos; Campos, 2006), inseridas no contexto da reflexão e reconstrução do processo saúde-doença-intervenção atuais no país, possam ser incorporadas na área da vacinação. A autonomia, entendida não como "contrário de dependência" ou "como liberdade absoluta", mas como um processo democraticamente construído inserido na dialética entre indivíduo coletivo (Campos; Campos, 2006), possa ser alcançada diante de um caminho de corresponsabilização, desde que a liberdade individual não ponha em risco a coletividade.

Por fim, ciente que as ações e reações de grupos sociais, neste caso, são respostas de uma interação complexa entre medicina e sociedade, que ambas sofrem influências de transformações sociais mais amplas, e que o conceito de cuidado em saúde incorpora a responsabilização no ato de cuidar; este trabalho ressalta a importância do reconhecimento que o cuidado, no tocante às vacinas e à vacinação, é uma questão que extrapola o âmbito individual e diz respeito a uma responsabilidade que também é coletiva. 


\section{ANEXOS}

\section{Anexo 1. Roteiro da entrevista em profundidade}

- Fale como foi para você o desejo de ter filho(s).

- Conte sobre a sua vivência na gestação e parto do(s) seu(s) filho(s).

- Relate sua experiência nos cuidados diretos e cotidianos do(s) seu(s) filho(s). E como foi a experiência para seu (sua) parceiro(a)?

- Conte sobre sua vivência nas questões de saúde do seu(s) filho(s) (ida ao pediatra, cuidado em caso de doenças agudas, etc.). E a do seu (sua) parceiro (a)?

- Conte como foi o processo de vacinação ou não do(s) seu(s) filho(s).

- Como foi isso no $1^{\circ}$ e no $2^{\circ}$ filho? Houve diferença?

- Como se deu essa decisão no casal, existe divergências? Como vocês tratam estas divergências?

- Sua opinião sobre vacinação é a mesma ou mudou após você se tornar mãe/pai?

- Quais foram as influências em vacinar ou não vacinar seu (s) filho (s)?

- Fale sobre sua relação com o pediatra e a decisão sobre vacinação?

- Como você se sente no presente acerca da decisão que tomou sobre a vacinação de seu(s) filho(s). Como você se sente no tocante a esta decisão frente ao seu círculo de relacionamento (família, amigos, etc.)?

- Você tem alguma experiência boa, ruim ou peculiar na vacinação com seu (s) filho (s)?

- Você tem algo a acrescentar? 


\section{Anexo 2. Termo de Consentimento Livre e Esclarecido}

O objetivo geral deste estudo, intitulado "Parentalidade e cuidado: representações de pais e mães acerca da vacinação de seus filhos" é conhecer as representações de pais e mães de classe média escolarizada de São Paulo-SP acerca da vacinação de seus filhos.

Para sua realização serão realizadas entrevistas com pais e mães de classe média escolarizada que moram no município de São Paulo-SP, contendo questões abertas. As entrevistas serão gravadas e serão garantidos total anonimato e confidencialidade.

A sua participação neste estudo é voluntária e em momento algum seu nome será associado ao estudo. O resultado dessa pesquisa, quando divulgado, irá garantir o total anonimato e a confidencialidade dos participantes. É garantida a liberdade da retirada de seu consentimento a qualquer momento e de você deixar de participar do estudo. Não há despesas pessoais de qualquer espécie para você e nem compensação financeira relacionada à sua participação. Você terá o direito de saber dos resultados parciais e finais da pesquisa. Comprometemos-nos a utilizar os dados e o material coletado somente para esta pesquisa.

Em qualquer etapa do estudo, você terá acesso aos profissionais responsáveis pela pesquisa para esclarecimento de eventuais dúvidas. A principal investigadora é a Prof. Dra. Márcia Thereza Couto Falcão, que pode ser encontrada no endereço Av. Dr Arnaldo, $4552^{\circ}$ andar, sala 2177, CEP:01246-903 -São Paulo-SP Fone: 5511 30618278, 3061-8692 - FAX: 55113061 8466. A pesquisadora executante da pesquisa é a Dra. Carolina Luisa Alves Barbieri, que poderá ser encontrada no endereço anteriormente apontado. Se você tiver alguma consideração ou dúvida sobre a ética da pesquisa, entre em contato com o Comitê de Ética em Pesquisa (CEP) - Rua Ovídio Pires de Campos, 225 - $5^{\circ}$ andar - tel: 3069-6442 ramais 16, 17, 18 ou 20, FAX: 30696442 ramal 26 - E-mail: cappesq@ honet.usp.br.

$\mathrm{Eu}$ discuti com a Dra. Carolina Luisa Alves Barbieri, a pesquisadora executante, sobre a minha decisão em participar nesse estudo. Ficaram claros para mim quais são os propósitos do estudo, os procedimentos a serem realizados, seus desconfortos e riscos, as garantias de confidencialidade e de esclarecimentos permanentes. Concordo voluntariamente em participar deste estudo e poderei retirar o meu consentimento a qualquer momento, antes ou durante o mesmo, sem penalidades ou prejuízo.

Nome:

Assinatura do participante

Data 11

Declaro que obtive de forma apropriada e voluntária o Consentimento Livre e Esclarecido deste participante para a participação neste estudo.

Assinatura do responsável pelo estudo

Carolina Luísa Alves Barbieri

Data $1 /$ 


\section{Anexo 3. Parecer do Comitê de Ética em Pesquisa}

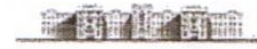 \\ MEDICINA \\ TSP \\ COMITÊ DE ÉTICA EM PESQUISA}

O Comitê de Ética em Pesquisa da Faculdade de Medicina da Universidade de São Paulo, em sessão de 15.09.10, APROVOU o Protocolo de Pesquisa $\mathrm{n}^{\circ}$ 251/10 intitulado: "Parentalidade e cuidado: representações de pais e mães acerca da vacinação de seus filhos" e seus anexos, apresentado pelo Departamento de Medicina Preventiva

Cabe ao pesquisador elaborar e apresentar ao CEP-FMUSP, os relatórios parciais e final sobre a pesquisa .

Pesquisador (a) Responsável: Marcia Thereza Couto Falcão

Pesquisador (a) Executante: Carolina Luisa Alves Barbieri,

CEP-FMUSP, 15 de setembro de 2010.

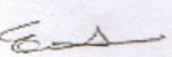

Prof. Dr. Eduardo Massad

Coordenador

Comitê de Ética em Pesquisa

Comitê de Ética em Pesquisa da Faculdade de Medicina da Universidade de São Paulo Rua Ovídio Pires de Campos, 225, $5^{\circ}$ andar - CEP 05403010 - São Paulo - SP Fone: 01130696442 Fax: 01130696492 e-mail: 


\section{REFERÊNCIAS BIBLIOGRÁFICAS}

ABEP. Associação Brasileira de Empresas de Pesquisa. Critério de Classificação Econômica Brasil, 2011. Disponível em: <http://www.abep.org/novo/Content.aspx? ContentID=301> Acesso em: 03/11/2011.

Andrade RP, Costa NRA, Rossetti-Ferreira MC. Significações de paternidade adotiva: Um estudo de caso. Paidéia (Ribeirão Preto). 2006; 16: 241-252.

ANVISA. Agência Nacional de Vigilância Sanitária. Resolução RE nº 528, de 17 de abril de 2001. Diário Oficial da União, 18/04/2001.

Almeida JAG, Novak FR. Amamentação: um híbrido natureza-cultura. Jornal de Pediatria. 2004; 80 (supl.5): S119-S125.

Aquino EML. Gênero e saúde: perfil e tendências da produção científica no Brasil. Rev Saúde Pública. 2006; 40: 121-32.

Ariès P. História Social da criança e da família. 2a ed. Rio de Janeiro: Zahar editores, 1981.

Ayres JRCM. Sujeito, intersubjetividade e práticas de saúde. Ciência e Saúde Coletiva. 2001; 6 (1): 63-72.

Cuidado e reconstrução das práticas de saúde. Interface - Comunicação, Saúde e Educação. 2003; 8 (14): 73-92.

O cuidado, os modos de ser (do) humano e as práticas de saúde. Saúde e Sociedade. 2004; 13 (3): 16-29.

. Uma concepção hermenêutica de saúde. PHYSIS: Rev. Saúde Coletiva. 2007; 17 (1): 43-62.

2008.

Sobre o risco: para compreender a epidemiologia. 3a ed. São Paulo: Hucitec,

Ayres JR, Paiva V, França Jr. I. Conceitos e práticas de prevenção: da história natural da doença ao quadro da vulnerabilidade e direitos humanos. In: Paiva V, Ayres JR, Buchalla CM. Vulnerabilidade e direitos humanos - prevenção e promoção da saúde: da doença a cidadania -Livro 1. Curitiba: Juruá, 2012: 71-94.

Azzan Jr. C. Antropologia e Interpretação: explicação e compreensão nas Antropologias de Lévi-Strauss e Geertz. [S. I.]: Unicamp, 1993.

Badinter E. Um amor conquistado: $O$ mito do amor materno. 7a ed. Rio de Janeiro: Nova Fronteira, 1985.

XY: Sobre a identidade masculina. Rio de Janeiro: Nova Fronteira, 1993. 
O conflito: a mulher e a mãe. Rio de Janeiro: Record, 2011.

Barata RB, Ribeiro MCSA, Moraes JC, Flannery B, on behalf of the Vaccine Coverage Survey 2007 Group. Socioeconomic inequalities and vaccination coverage: results of an immunisation coverage survey in 27 Brazilian capitals, 2007-2008. J Epidemiol Community Health. 2012; 66 (10): 934-41.

Barreto ML, Teixeira MG, Bastos FI, Ximenes RA, Barata RB, Rodrigues LC. Successes and failures in the control of infectious diseases in Brazil: social and environmental context, policies, interventions, and research needs. Lancet. 2011; 377 (9780): 1877-89.

Barbieri JC. Desenvolvimento e meio ambiente: as estratégias de mudanças da agenda 21. 13a ed. Petrópolis, RJ: Vozes, 2011.

Barbieri CLA, Dias C, Santos MAN, Veras MASM, Moraes JC, Petlik MEI. Cobertura vacinal infantil em um serviço filantrópico de atenção primária à saúde do Município de São Paulo, Estado de São Paulo, Brasil, em 2010. Epidemiol. Serv. Saúde. 2013; 22(1):129-139.

Beck U. Sociedade de risco: rumo a uma outra modernidade. São Paulo: Ed. 34, 2010.

Becker H. Métodos de pesquisa em ciências sociais. São Paulo: Hucitec, 1992.

Bedford H, Elliman D. Concerns about immunization. BMJ. 2000; 320: 240-3.

Benin AL, Wisler-Scher DJ, Colson E, Shapiro ED, Holmboe ES. Qualitative analysis of mothers' decision-making about vaccines for infants: the importance of trust. Pediatrics, 2006; 117 (5): 1532-1541.

Brasil. Lei n 6.259 de 30 de outubro de 1975. Dispõe sobre a organização das ações de vigilância epidemiológica, sobre o programa nacional de imunizações, estabelece normas relativas à notificação compulsória de doenças, e dá outras providências. Diário Oficial da União. 1975; 31 out.

Brasil. Decreto $n^{\circ} 78.231$ de 12 de agosto de 1976. Regulamenta a Lei $\mathrm{n}^{\circ} 6.259$, de 30 de outubro de 1975, que dispõe sobre a organização das ações de vigilância epidemiológica, sobre o programa nacional de imunizações, estabelece normas relativas a notificação compulsória de doenças, e dá outras providências. Diário Oficial da União. 1976; 13 ago.

Brasil. Lei ${ }^{\circ} 8.069$ de 13 de julho de 1990. Dispõe sobre o Estatuto da Criança e do Adolescente e dá outras providências. Diário Oficial da União. 1990, 16 jul: 13563.

Brasil. Ministério da Saúde. Secretaria de Vigilância em Saúde. Programa Nacional de Imunizações - 30 anos. Brasília: Ministério da Saúde, 2003.

Brasil. Ministério da Saúde. Secretaria de Vigilância em Saúde. Departamento de Vigilância Epidemiológica. Manual de Vigilância Epidemiológica de Eventos Adversos Pós-Vacinação. Brasília: Ministério da Saúde, 2008. 
Bustamante V, Trad LAB. Participação paterna no cuidado da saúde de crianças pequenas: um estudo etnográfico com famílias de camadas populares. Cad. Saúde Pública. 2005; 21 (6): 1865-74.

Cabral SALCS, Costa CFF, Cabral Jr SF. Correlação entre a idade materna, paridade, gemelaridade, síndrome hipertensiva e ruptura prematura de membranas e a indicação de parto cesáreo. Rev Bras Ginecol Obstet. 2003; 25 (10): 739-44

Campos RTO, Campos GWS. Co-construção de autonomia: o sujeito em questão. In: Campos, Gastão Wagner de Sousa; Minayo, Maria Cecília de Souza; Akerman, Marco; Drumond Júnior, Marcos; Carvalho, Yara Maria de. Tratado de saúde coletiva. Rio de Janeiro, Hucitec;Fiocruz, 2006: 669-688.

Carrilho MR. O cuidado como ser e o cuidado como agir. Ex aequo. 2010; 21: 107-114.

Carvalho SR. Os múltiplos sentidos da categoria "empowerment" no projeto de Promoção à Saúde. Cad. Saúde Pública. 2004; 20 (4): 1088-1095.

Castells M. A Sociedade em Rede: do Conhecimento à Política. In: a sociedade em rede: do conhecimento à acção política. Castells M, Cardoso G (Org.), 2005: 17-30.

Castiel LD, Guilam MCR, Ferreira MS. Correndo o risco: uma introdução aos riscos em saúde. Rio de Janeiro: Fiocruz, 2010.

CDC. Centers for Disease Control and Prevention. Transmission of Yellow Fever Vaccine Virus Through Breast-Feeding - Brazil, 2009. MMWR. 2010; 59 (5): 130-132.

CFM. Conselho Federal de Medicina e Sociedade de Pediatria de São Paulo. Manual de Atendimento às Crianças e Adolescentes Vítimas de Violência. Waksman RD, Hirschheimer MR, (Coord.). Brasília/DF, 2011.

CGPNI. Coordenação Geral do Programa Nacional de Imunizações. Brasil. [Ministério da Saúde. Secretaria de Vigilância em Saúde. Departamento de Vigilância Epidemiológica.] Informe técnico da introdução da vacina inativada poliomielite (VIP). Brasília, 2012a.

CGPNI. Coordenação Geral do Programa Nacional de Imunizações. [Ministério da Saúde. Secretaria de Vigilância em Saúde. Departamento de Vigilância Epidemiológica.] Informe técnico da introdução da vacina pentavalente: Vacina adsorvida difteria, tétano, pertussis, hepatite $B$ (recombinante) e Haemophilus influenzae tipo b (conjugada). Brasília, 2012b.

CGPNI. Coordenação Geral do Programa Nacional de Imunizações. [Ministério da Saúde. Secretaria de Vigilância em Saúde. Departamento de Vigilância Epidemiológica.] Informe técnico da introdução da vacina adsorvida Hepatite a (inativada). Brasília, 2013a.

CGPNI. Coordenação Geral do Programa Nacional de Imunizações. [Ministério da Saúde. Secretaria de Vigilância em Saúde. Departamento de Vigilância Epidemiológica.] Informe técnico de introdução da vacina tetra viral: Vacina sarampo, caxumba, rubéola e varicela (atenuada) Brasília, 2013b. 
CGPNI. Coordenação Geral do Programa Nacional de Imunizações. [Ministério da Saúde. Secretaria de Vigilância em Saúde. Departamento de Vigilância Epidemiológica.] Informe técnico sobre a vacina papilomavírus humano (HPV) na atenção básica. Brasília, 2013c.

CGPNI. Coordenação Geral do Programa Nacional de Imunizações. [Ministério da Saúde. Secretaria de Vigilância em Saúde. Departamento de Vigilância Epidemiológica.] Posição do Ministério da Saúde do Brasil sobre a Declaração de Emergência Sanitária Mundial, relacionada ao aumento dos casos de poliomielite no mundo. Brasília, 2014.

Colgrove J, Bayer R. Could it happen here? Vaccine risk controversies and the specter of derailment. Health Aff (Millwood). 2005; 24: 729-739.

Costa JF. Ordem médica e norma familiar. 4a ed. [S. I]: Graal, 1999.

Costa RG. Reprodução e gênero: paternidades, masculinidades e teorias da concepção. Estudos feministas. 2002; 2: 339-356.

Couto MT. Estudos de famílias populares urbanas e a articulação com gênero. Revista Anthropológicas. 2005; 16(1): 197-215.

Couto MT, Pinheiro TF, Valença O, Machin R, Silva GSN, Gomes R, Schraiber LB, Figueiredo WS. O homem na atenção primária à saúde: discutindo (in)visibilidade a partir da perspectiva de gênero. Interface - Comunicação, Saúde, Educação. 2010; 14 (33): 257-270.

CVE. Centro de Vigilância Epidemiológica "Prof. Alexandre Vranjac". [Estado de São Paulo. Secretaria de Estado da Saúde. Coordenadoria de Controle de Doenças.] Alerta sarampo: atualização da situação epidemiológica. Fevereiro de 2014. Disponível em: http://www.cve.saude.sp.gov.br/htm/resp/dex_doctec.html

Cukierman H. Yes, nós temos Pasteur: Manguinhos, Oswaldo Cruz e a história da ciência no Brasil. Rio de Janeiro: Relume Dumará: FAPERJ, 2007.

Damião JJ. Influência da escolaridade e do trabalho maternos no aleitamento materno exclusivo. Rev Bras Epidemiol. 2008; 11(3): 442-52.

Demo P. Ambivalências da sociedade de informação. Ci. Inf. 2000; 29 (2): 37-42.

Deslandes SF, Ayres JRCM. Humanização e cuidado em saúde. Ciênc. saúde coletiva. 2005; 10 (3): 510-510.

Diniz CSG. Humanização da assistência ao parto no Brasil: os muitos sentidos de um movimento. Ciênc. saúde coletiva. 2005; 10 (3): 627-637.

Domingues CMAS, Teixeira AMS. Coberturas vacinais e doenças imunopreveníveis no Brasil no período 1982-2012: avanços e desafios do Programa Nacional de Imunizações. Epidemiol serv saúde 2013; 22 (1): 9-27.

Donnangelo MCF. Saúde e sociedade. São Paulo: Duas cidades, 1976. 
Escobar AMU, Ogawa AR, Hiratsuka M, Kawashita MY, Teruya PY, Grisi S, Tomikawa SO. Aleitamento materno e condições socioeconômico-culturais: fatores que levam ao desmame precoce. Rev. bras. saúde matern. Infant. 2002; 2 (3): 253-261.

Espanha R. Informação e Sáude. Fundação Francisco Manuel dos Santos, 2013.

Falceto, OG, Fernandes CL, Baratojo C, Giugliani ERJ. Fatores associados ao envolvimento do pai nos cuidados do lactente. Rev. Saúde Pública. 2008; 42 (60): 10341040.

Faleiros, FTV, Trezza EMC, Carandina L. Aleitamento materno: fatores de influência na sua decisão e duração. Rev. Nutr. 2006; 19(5):623-630.

Feliciano KVO. Abordagem qualitativa na avaliação em saúde. In: Samico E et al. Avaliação em saúde: bases conceituais e operacionais. Rio de Janeiro: Medbook, p. 2942, 2010.

Figueira SA. O moderno e o arcaico na nova família brasileira: notas sobre a dimensão invisível da mudança social. In: Figueira, SA. Uma nova família? Rio de Janeiro: Jorge Zahar, 1987: 11-30.

Fonseca C. Honra, humor e relações de gênero: um estudo de caso. In: Costa AO, Bruschini C (Org.). Uma questão de gênero. Rio de Janeiro: Rosa dos tempos, 1992. (16): 281-6.

A interpretação das culturas: festejando 35 anos. Cadernos de campo, 2008; 16

Fontana A, Frey JH. The interwiew. From strutured questions to negotiated text. In: Denzin NK \& Lincoln YS. Handbook of qualitative research. 2th ed. Thousand Oaks, CA: Sage Publications; 2000.

Fontanella BJ, Ricas J, Turato ER. Amostragem por saturação em pesquisas qualitativas em saúde: contribuições teóricas. Cad saúde pública 2008; 24 (1): 17-27.

Freire MML. 'Ser mãe é uma ciência': mulheres, médicos e a construção da maternidade científica na década de 1920. História, Ciências, Saúde - Manguinhos. 2008; 15: 153-171.

Mulheres, mães e médicos: discurso maternalista no Brasil. Rio de Janeiro: Editora FGV, 2009.

Freitas WMF, Silva ATMC, Coelho EAC, Guedes RN, Lucena KDT, Costa APT. Paternidade: responsabilidade social do homem no papel de provedor. Rev Saúde Pública. 2009; 43 (1): 85-90.

Freyre G. Casa-grande e senzala. 19a ed. Rio de Janeiro: Livraria José Olympio, 1978.

Garbin HBR, Pereira Neto AF, Guilam MCR. A internet, o paciente expert e a prática médica: uma análise bibliográfica. Interface - Comunic., Saúde, Educ. 2008; 12 (26): 579-88. 
Geertz C. A interpretação das culturas. Rio de janeiro: LTC, 2008.

Godlee F, Smith J, Marcovitch H. Wakefield's article linking MMR vaccine and autism was fraudulent. BMJ. 2011; 342: 64-66.

Goldani AM. As famílias brasileiras: mudanças e perspectivas. Cad. Pesq. 1994; 91: 722.

Gomes R, Souza ER, Minayo MCS, Malaquias JV, Silva CFR. Organização, processamento, análise e interpretação de dados: o desafio da triangulação. In: Minayo MCS, Assis SG, Souza ER (Orgs.). Avaliação por triangulação de métodos: abordagem de programas sociais. Rio de Janeiro: Fiocruz, 2005: 185-221.

Grossi M, Heilborn ML, Rial C. Entrevista com Joan Wallach Scott. Revista Estudos Feministas. 1998; 6 (1): 114-124.

Gutierrez DMD, Minayo MCS. Produção de conhecimento sobre cuidados da saúde no âmbito da família. Ciência \& Saúde Coletiva. 2010; 15 (supl. 1): 1497-1508.

Guzmán LJ. Reflexiones acerca de la paternidad. La Manzana. 2008; III (4). Disponível em: http://www.estudiosmasculinidades.buap.mx/num4/reflexiones.htm Acesso em: $11 / 12 / 2011$.

Hochman G. Vacinação, varíola e a cultura da imunização no Brasil. Ciênc. saúde coletiva. 2011; 16 (2): 375-86.

Kata A. A postmodern Pandora's box: Anti-vaccination misinformation on the Internet. Vaccine. 2010; 28 (7): 1709-16.

Kendall C, Kerr LR, Gondim RC, Werneck GL, Macena RH, Pontes MK, et al. An Empirical Comparison of Respondent-driven Sampling, Time Location Sampling, and Snowball Sampling for Behavioral Surveillance in Men Who Have Sex with Men, Fortaleza, Brazil. AIDS Behav. 2008; 12 (Suppl. 4): S97-104.

Leask J, Kinnersley P, Jackson C, Cheater F, Bedford H, Rowles G. Communicating with parents about vaccination: a framework for health professionals. BMC Pediatrics. 2012; 12: 154.

Lopes MB, Polito R. "Para uma história da vacina no Brasil": um manuscrito inédito de Norberto e Macedo. História, Ciências, Saúde - Manguinhos. 2007; 14 (2): 595-605.

Martins-Costa SH, Hammes LS, Ramos JG, Arkader J, Corrêa MD, Camano L. Cesariana - indicações. Projeto Diretrizes da Associação Médica Brasileira e Conselho Federal de Medicina. Agosto de 2002. Disponível em: <http://www.projetodiretrizes.org.br/projeto_diretrizes/032.pdf> Acessado em 05 de junho de 2014.

Meincke SMK, Carraro TE. Vivência da paternidade na adolescência: sentimentos expressos pela família do pai adolescente. Texto Contexto Enferm. 2009; 18(1): 83-91. 
Mills E, Jadad AR, Ross C, Wilson K. Systematic review of qualitative studies exploring parental beliefs and attitudes toward childhood vaccination identifies common barriers to vaccination. J Clin Epidemiol. 2005; 58 (11): 1081-8.

Minayo MCS. Hermenêutica-dialética como caminho do pensamento social. In: Minayo MCS, Deslandes SF. Caminhos do pensamento: epistemologia e método. Rio de Janeiro: Fiocruz, 2008: 83-107.

Moraes JC, Barata RB, Ribeiro MCSA, Castro PC. Cobertura vacinal no primeiro ano de vida em quatro cidades do Estado de São Paulo, Brasil. Rev Panam Salud Publica. 2000; 8 (5): 332-41.

Moraes JC, Ribeiro MCSA, Simões O, Castro PC, Barata RB. Qual a cobertura vacinal real? Epidemiol. Serv. Saúde. 2003; 12(3): 147-53.

Moraes JC, Ribeiro MCSA. Desigualdades sociais e cobertura vacinal: uso de inquéritos domiciliares. Revista Brasileira Epidemiologia. 2008; 11 (supl. 1): 113-24.

Moulin AM. A hipótese vacinal: por uma abordagem crítica e antropológica de um fenômeno histórico. Hist ciênc saúde-Manguinhos. 2003; 10 (supl. 2): 499-517.

Novaes HMD. A puericultura em questão. In: Mota A, Schraiber LB. Infância e saúde perspectivas históricas. São Paulo: Hucitec, 2009: 121-170.

Nunes ESN. A infância como portadora do futuro: América Latina: 1916-1948 [tese]. São Paulo: Faculdade de Filosofia, Letras e Ciências Humanas da Universidade de São Paulo: 2011.

Offit PA. Vacinado: A luta de um homem para vencer as doenças mais mortais do mundo. São Paulo: Ideia \& Ação, 2008.

Orlandi O. Teoria e prática do amor à criança: Introdução à pediatria social no Brasil. Rio de Janeiro: Jorge Zahar, 1985.

Outhwait W, Bottomore T, Gellner E, Nisbet R, Touraine A. Dicionário do Pensamento Social do séc. XX. Rio de Janeiro: Jorge Zahar, 1996.

Paim J, Travassos C, Almeida C, Bahia L, Macinko J. The Brazilian health system: history, advances, and challenges. Lancet. 2011; 377 (9779): 1778-1797.

Pará M. An Outbreak of Post-Vaccinal Rabies (Rage de Laboratoire) in Fortaleza, Brazil, in 1960. Bull. Org. mond. Santé; Bull. Wid Hith Org. 1965; 33: 177-182.

Piccinini CA, Silva MR, Gonçalves TR, Lopes RS, Tudge J. O envolvimento paterno durante a gestação. Psicol Reflex Crit. 2004; 17: 303-14.

Pinto LLS. O programa nacional de imunizações para além do controle das doenças imunopreviníveis. Uma história de 30 anos. Revista Baiana de Saúde Pública. 2004; 20 (1): 91-95.

Plotkin SA, Orenstein W, Offit P. Vaccines. 5a ed. [S. I.]: Saunders Elsevier, 2008. 
Poland GA, Jacobson RM. Understanding those who do not understand: a brief review of the anti-vaccine movement. Vaccine. 2001; 19 (17-19): 2440-5.

Pontes CM; Alexandrino AC; Osório MM. Participação do pai no processo da amamentação: vivências, conhecimentos, comportamentos e sentimentos. J. Pediatr. (Rio J.). 2008; 84 (4): 357-364.

Porto MY. Uma revolta popular contra a vacinação. Cienc. Cult. 2003; 55 (1): 53-54.

Poupart J. A entrevista de tipo qualitativo: considerações epistemológicas, teóricas e metodológicas. In: Poupart, J. et al. A pesquisa qualitativa: enfoques epistemológicos e metodológicos. Petrópolis, RJ: Vozes, 2008.

Quadros MT. Paternidade, trabalho doméstico e envolvimento com os/as filhos/as. In: Campos, RBC; Hoffnagel JC (Org.). Pensando família, gênero e sexualidade. Recife: Ed. Universitária, 2006: 59-98.

Rose G. Estratégias da medicina preventiva. Com comentários de Khae KT, Marmot M. São Paulo: Artmed, 2010.

Santos BS. Reconhecer para libertar: os caminhos do cosmopolitanismo multicultural. Rio de Janeiro: Civilização Brasileira, 2003.

Santos CA. Onde está o papai? A construção da paternidade nas pedagogias culturais, $2005 . \quad$ Disponível em: $<$ http://www.aleitamento.com.br/a_artigos.asp?id=x\&id_artigo=993\&id_subcategoria= 3> Acesso em 11/12/2011.

Sarti CA. Reciprocidade e hierarquia: relações de gênero na periferia de São Paulo. Cad. Pesq. 1989; 70: 38-46.

Considerações finais. In Sarti CA. O reconhecimento do Outro: uma busca de diálogo entre ciências humanas e ciências da saúde. Livre docência. São Paulo: Universidade Federal de São Paulo, 2003: 127-9.

Scavone L. Maternidade: transformações na família e nas relações de gênero. Interface Comunicação, Saúde, Educação. 2001; 5 (8): 47-60.

Schraiber LB. O médico e suas interações: a crise dos vínculos de confiança. São Paulo: Aderaldo \& Rothschild, 2008.

Scott JW. Gênero: uma categoria útil de análise histórica. Educação e Realidade. 1995; 20 (2): 71-99.

O enigma da igualdade. Estudos Feministas. 2005; 13(1): 11-30.

Scott P. A família brasileira diante de transformações no cenário histórico global. ANTHOPOLÓGICAS. 2005; 16 (1): 217-242. 
Seabra KC. A paternidade em famílias contemporâneas. Polêm!ca Revista Eletrônica. 2009. Disponível em: <http://www.polemica.uerj.br/8(1)/artigos/contemp_2.pdf> Acesso em: 05 de agosto de 2012.

Sevcenko N. A revolta da vacina: mentes insanas em corpos rebeldes. São Paulo: Scipione, 1993.

Silva MR, Piccinini CA. Sentimentos sobre a paternidade e o envolvimento paterno: um estudo qualitativo. Estudos de Psicologia. 2007; 24(4): 561-573.

Singly F. Sociologia da família contemporânea. Lisboa: Texto \& Grafia, 2010.

Souza CLC, Benetti SPC. Paternidade contemporânea: levantamento da produção acadêmica no período de 2000 a 2007. Paidéia. 2009; vol. 19 (42): 97-106.

Strey MN, Pulcherio G. As tramas de gênero na saúde. In: Strey MN, Nogueira C, Azambuja MR. Gênero e Saúde: diálogos ibero-brasileiros. Porto Alegre: Edipucrs, 2010: 11-33.

Sutter C, Buscher-Maluschke JSNF. Pais que cuidam dos filhos: a vivência masculina na paternidade participativa. Psico. 2008; 39 (1): 74-82.

Temporão JG. O Programa Nacional de Imunizações (PNI): origens e desenvolvimento. História, Ciências, Saúde - Manguinhos. 2003; 10 (supl. 2): 601-17.

Tesser CD, Knobel, R, Rigon T, Bavaresco CZ. Os médicos e o excesso de cesárias no Brasil. Sau. \& Transf. Soc. 2011; 2 (1): 04-12.

Tornquist CS. Armadilhas da Nova era: natureza e maternidade no ideário da humanização do parto. Revista Estudos Feministas. 2002; 10 (2): 483-92.

Paradoxos da humanização em uma maternidade no Brasil. Cad. Saúde Pública. 2003; 19 (Sup. 2): S419-S427.

Tronchin DMR, Tsunechiro MA. Cuidar e o conviver com o filho prematuro: a experiência do pai. Rev Latino-am Enfermagem. 2006; 14(1): 93-101.

Vaitsman J. Flexíveis e plurais: identidade, casamento e família em circunstâncias pósmodernas. Rio de Janeiro: Editora Rocco, 1994.

Vandamme E. Concepts and challenges in the use of Knowledge-Attitude-Practice surveys: Literature review. 2009. Disponível em: <http://www.onehealthnet.be/review2.html> Acesso em: 07/01/2012.

Vasconcellos-Silva PR, Castiel LD. A internet na história dos movimentos antivacinação. ComCiência. 2010; 121.

Vieira EM. A medicalização do corpo feminino. Rio de Janeiro: Ed. Fiocruz, 2008. 
Vieira MAN. Educação e sociedade da informação: uma perspectiva crítica sobre as TIC num contexto escolar. [dissertação]. Braga: Instituto de Educação e Psicologia, Universidade do Minho: 2005.

Velásquez AS, Campos GP. La paternidad em los varones: uma búsqueda de identidad em um terreno desconocido. La Manzana. 2008; III (4). Disponível em: <http://www.estudiosmasculinidades.buap.mx/num4/varones.htm> Acesso em:11/12/2011.

Velho G. Individualismo e cultura: notas para uma antropologia da sociedade contemporânea. 2a ed. Rio de Janeiro: Jorge Zahar, 1987.

Projeto e metamorfose: antropologia das sociedades complexas. 3a ed. Rio de Janeiro: Jorge Zahar, 1994.

Victora CG, Aquino EML, Leal MC, Monteiro CA, Barros FC, Szwarcwald CL. Maternal and child health in Brazil: progress and challenges. Lancet 2011; 377:1863-76.

Waldman EA. Mesa-Redonda: Desigualdades sociais e cobertura vacinal: uso de inquéritos domiciliares. Rev Bras Epidemiol. 2008; 11(supl 1): 129-32.

Wakefield A J, Murch SH, Anthony A, Linnell J, Casson DM, Malik M, et al. Ileallymphoid-nodular hyperplasia, non-specific colitis, and pervasive developmental disorder in children. Lancet. 1998; 637-41. Retraction in: Lancet. 2010; 375 (9713): 445 .

WHO. World Health Organization. New and Under-utilized Vaccines Implementation (NUVI). 5th Global Meeting on Implementing New and Under-utilized Vaccines, 2011. Disponível em: <http://www.who.int/nuvi/2011_meeting_summary_CommunicationNUVI/en/> Acesso em: 07/01/2012.

Wolfe RM, Sharp LK. Anti-vaccinationistis past and present. BMJ. 2002; 325: 430-2.

Wolfe RM, Sharp LK, Lipsky MS. Content and design attributes of antivaccination web sites. JAMA. 2002; 287: 3245-3248. 